
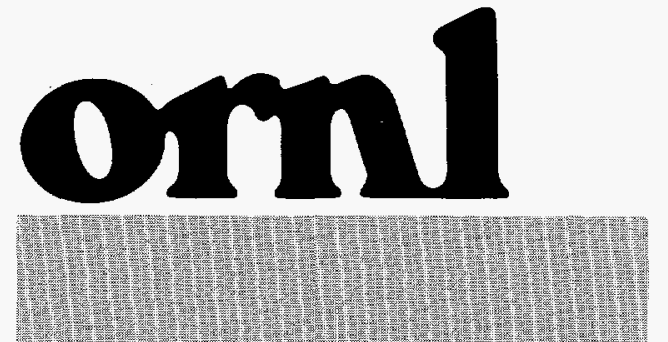

OAK RIDGE
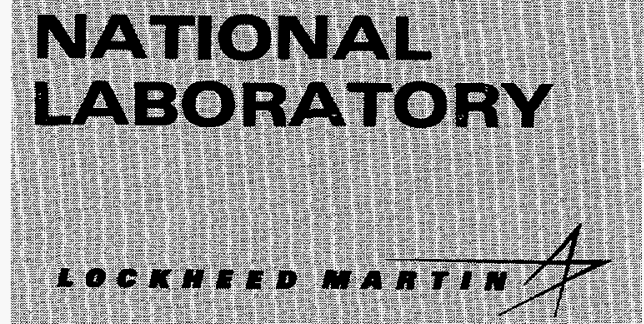

\section{Supporting Documentation for the 1997 Revision to the DOE Insulation Fact Sheet}

\author{
RECEIVED

$\begin{array}{rr}\text { JAN } 151998 & \text { Therese K. Stovall } \\ \text { OSTI } & \\ \text { August 22, } 1997\end{array}$

Building Thermal Envelope Systems and Materials Program

Prepared for the

U.S. Department of Energy

Office of Energy Efficiency and Renewable Resources

Prepared by the

OAK RIDGE NATIONAL LABORATORY

Oak Ridge, Tennessee 37831

managed by

LOCKHEED MARTIN ENERGY RESEARCH CORP.

For the U.S. Department of Energy

under contract No. DE-AC05-96OR22464

This report was prepared as an account of work sponsored by an agency of the United States Government. Neither the United States Government nor any agency thereof, nor any of their employees, makes any warranty, express or implied, or assumes any legal liability or responsibility for the accuracy, completeness, or usefulness of any information, apparatus, product, or process disclosed or represents that its use would not infringe privately owned rights. Reference herein to any specific commercial product, process, or service by trade name, trademark, manufacturer, or otherwise, does not necessarily constitute or imply its endorsement, recommendation, or favoring by the United States Government of any agency thereof. The views and opinions of authors expressed herein do not necessarily state or reflect those of the United States Government or any agency thereof.

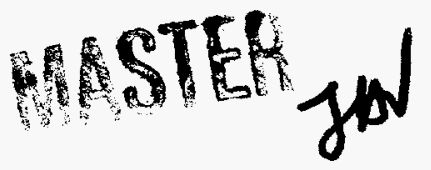




\section{DISCLAIMER}

This report was prepared as an account of work sponsored by an agency of the United States Government. Neither the United States Government nor any agency thereof, nor any of their employees, makes any warranty, express or implied, or assumes any legal liability or responsibility for the accuracy, completeness, or usefulness of any information, apparatus, product, or process disclosed, or represents that its use would not infringe privately owned rights. Reference herein to any specific commercial product, process, or service by trade name, trademark, manufacturer, or otherwise does not necessarily constitute or imply its endorsement, recommendation, or favoring by the United States Government or any agency thereof. The views and opinions of authors expressed herein do not necessarily state or reflect those of the United States Government or any agency thereof. 


\section{DISCLAIMER}

Portions of this document may be illegible electronic image products. Images are produced from the best available original document. 


\title{
Supporting Documentation for the 1997 Revision to the DOE Insulation Fact Sheet
}

\author{
Therese K. Stovall
}

August 22, 1997

Building Thermal Envelope Systems and Materials Program

Prepared for the

U.S. Department of Energy

Office of Energy Efficiency and Renewable Resources

Prepared by the

OAK RIDGE NATIONAL LABORATORY

Oak Ridge, Tennessee 37831

managed by

LOCKHEED MARTIN ENERGY RESEARCH CORP.

For the U.S. Department of Energy

under contract No. DE-AC05-960R22464. 


\section{Contents}

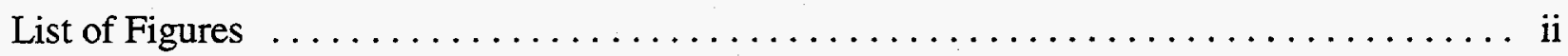

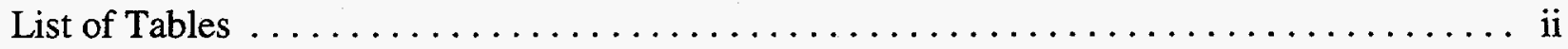

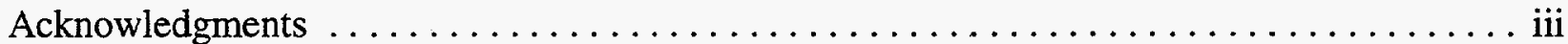

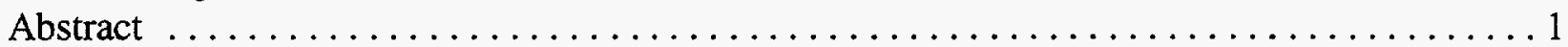

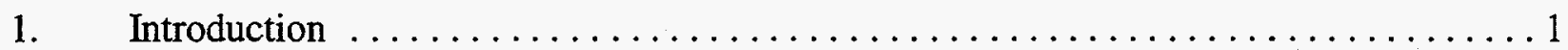

2. Energy Savings . . . . . . . . . . . . . . . . . . . . . . . . . . . . . . 1

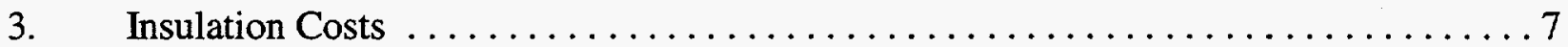

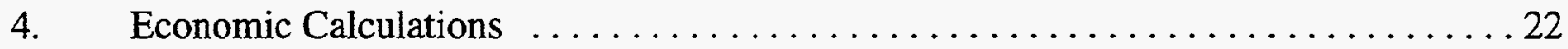

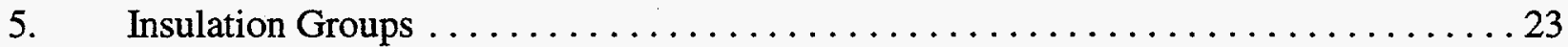

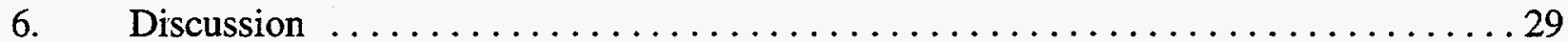

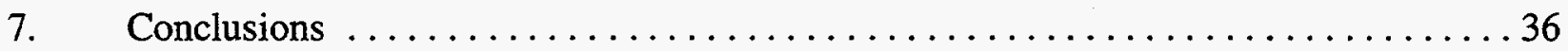

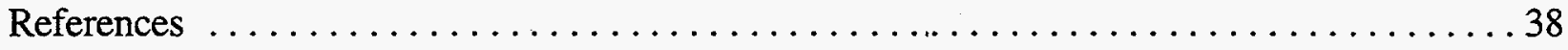

Appendix A: Climate and Cost Information Used in the Zip-code Computer Program . . . . A.1

Appendix B: Coefficients Used to Calculate Savings for Floor and Building Foundation

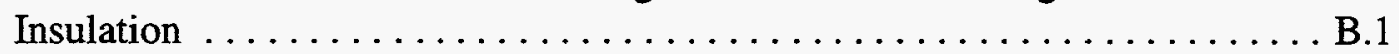

Appendix C: The Modified Zone Heat Transfer Model $\ldots \ldots \ldots \ldots \ldots \ldots \ldots \ldots \ldots$ C.1

Appendix D: Insulation Cost Survey Forms and Selected Results ............. D. 1

Appendix E: Insulation Cost Multipliers and Energy Prices for Electricity, Natural Gas, and

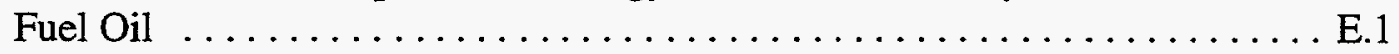

Appendix F: Residential Energy Price Escalation Factors $\ldots \ldots \ldots \ldots \ldots \ldots \ldots \ldots$ F. 1

Appendix G: Net Savings for Wall Insulation Options in New Construction ........... G.1

Appendix H: Summary of Comments Received During the Review Period for the Draft Version of the Doe Insulation Fact Sheet $\ldots \ldots \ldots \ldots \ldots \ldots \ldots \ldots \ldots \ldots \ldots \ldots \ldots . .1$ 


\section{List of Figures}

1. Map showing eight Insulation Zones identified in the 1988 DOE Insulation Fact Sheet (Alaska was Zone 8 and Hawaii, Puerto Rico, and the Virgin Islands were Zone 1.) . . 31

2. Map showing nine Insulation Zones identified in the 1997 DOE Insulation Fact Sheet . 32

\section{List of Tables}

1. Heating and cooling system performance assumptions $\ldots \ldots \ldots \ldots \ldots \ldots \ldots$

2. Constants used to calculate annual energy savings for attics and above-ground walls ... 3

3. Interpolation of heating season savings factors for metal-framed floors $\ldots \ldots \ldots \ldots$

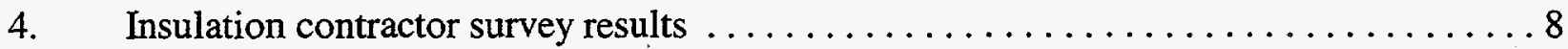

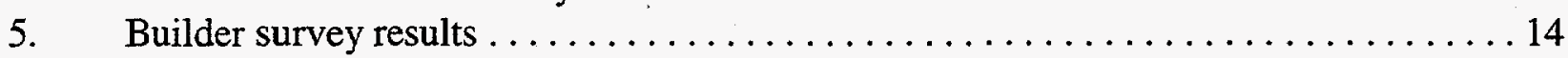

6. Retail prices for extruded polystyrene from 14 states $\ldots \ldots \ldots \ldots \ldots \ldots \ldots \ldots \ldots$

7. Insulation costs and thermal resistances used in the ZIP-Code computer program . . . . 16

8. Recommended insulation levels for existing houses from the 1997 DOE Insulation Fact

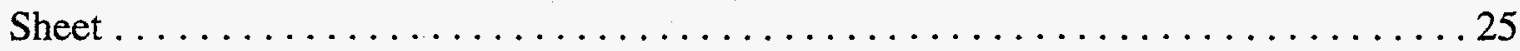

9. Recommended insulation levels for residential new construction from the $1997 \mathrm{DOE}$

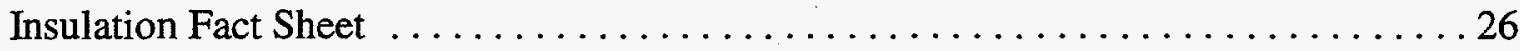

10. Zip Codes and corresponding Insulation Zones from the 1997 DOE Insulation Fact Sheet . . . . . . . . . . . . . . . . . . . . . . . 27

11. Insulation group assignment for each insulation zone from the 1997 DOE Insulation

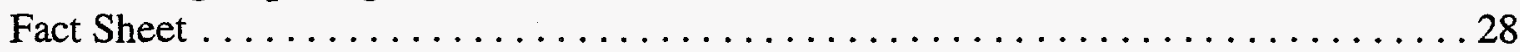

12. Distribution of heating system fuels for new construction and existing houses . . . . 28

13. Total effective $\mathrm{R}$-values for the recommended wall insulation combinations, including surface heat transfer coefficients, exterior siding, $1 / 2$ in. wood sheathing, joists, and

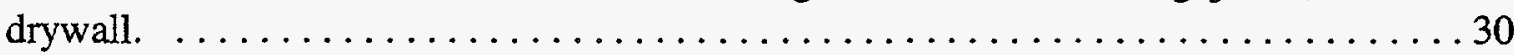

14. Comparison of recommended attic insulation R-values from the MEC, ASHRAE90.2,

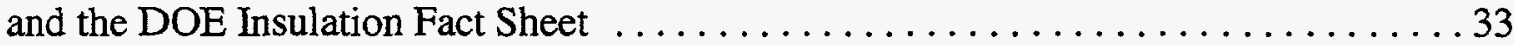

15. Recommended insulation levels from the 1988 DOE Insulation Fact Sheet . . . . . . 34

16. Effect of duct efficiency on recommended attic insulation levels. . . . . . . . 36 


\section{Acknowledgments}

This revision to the DOE Insulation Fact Sheet relies heavily on the text and methodology of the original fact sheet, generated by David McElroy and Thomas Kollie of Oak Ridge National Laboratory, and Stephen Petersen of the National Institute of Standards and Technology. The program has been ably directed at the Department of Energy by Peter Scofield, John Talbot, and Arun Vohra. Donald Clem, Peter Stratton, and Adrian Tuluca of Steven Winter Associates, Inc. directed the insulation cost survey, contacting over 3000 contractors. Kenneth Wilkes, David Yarbrough, and Jeffrey Christian have provided invaluable guidance during the revision process. Elena Koontz and Kara Kruse developed the Internet version of the ZIP-Code computer program and Ken Childs is responsible for the Fact Sheet's Internet site, both helpful sources of information for insulation consumers. Many reviewers, from trade associations, academia, and assorted governmental agencies, took the time to examine early drafts of the document and offered useful suggestions for improvements. 


\begin{abstract}
The Department of Energy (DOE) Insulation. Fact Sheet has been revised to reflect developments in energy conservation technology and the insulation market. A nation-wide insulation cost survey was made by polling insulation contractors and builders and the results are reported here. These costs, along with regional weather data, regional fuel costs, and fuel-specific system efficiencies were used to produce recommended insulation levels for new and existing houses. This report contains all of the methodology, algorithms, assumptions, references, and data resources that were used to produce the 1997 DOE Insulation Fact Sheet.
\end{abstract}

\title{
1. Introduction
}

The Department of Energy (DOE) first published an insulation fact sheet in $1978 .^{1}$ The publication's aim was to inform consumers about the advantages offered by insulation and to provide guidance that would lead to reasonable insulation purchases. This guidance took the form of recommended insulation $\mathrm{R}$-values for each part of a home, the recommendation varying with climate and heating fuel type. (An insulation R-value defines the thermal resistance of the material, in units of $\left.\mathrm{h} \cdot \mathrm{ft}^{2}{ }^{\circ} \mathrm{F} / \mathrm{Btu}\right)$. The fact sheet was revised in 1982 and again in 1988 and is distributed upon request to over 40,000 readers/year.

The 1997 revision to the DOE Insulation Fact Sheet again recommends varying levels of insulation for different parts of the country. ${ }^{2}$ This supporting document has been prepared to describe the basis for these insulation level recommendations. As with the previous version of the fact sheet, these recommendations were based on a life-cycle cost optimization strategy found in the ZIP-Code computer program, written by Stephen Petersen of the National Institute of Standards and Technology. ${ }^{3}$ The program's methodology is summarized here along with other assumptions and reference material used to prepare the Fact Sheet. The cost optimization relies on regional weather data, regional fuel costs, regional insulation costs, and fuel-specific system efficiencies. Differences are recognized for new and existing houses, primarily in the economic lifetime of insulation installations and in heating and cooling system efficiencies.

\section{Energy Savings}

Several performance assumptions were necessary to assess the optimal insulation investment level. Heating and cooling system assumptions are shown in Table 1. Heat pump 
efficiency was adjusted for the climate as shown in Eq. 1. ${ }^{3}$ Air conditioner use was assumed wherever there were more than 2000 cooling degree hours $(\mathrm{CDH})$ or if the heating system was a heat pump. The cooling degree hours were based on a $74^{\circ} \mathrm{F}$ balance point and the heating degree days (HDD) were based on a $65^{\circ} \mathrm{F}$ balance point, as provided in Ref. 4 and shown in Appendix A.

$$
\eta_{h}=1.06 \times\left(2.3-0.1 \times \frac{H D D}{1000}\right) \times \frac{H S P F}{6.7}
$$

where: $\eta_{\mathrm{h}}=$ adjusted heat pump heating efficiency,

$\mathrm{HDD}=$ heating degree days $\left(65^{\circ} \mathrm{F}\right.$ balance point $)$, and

$\mathrm{HSPF}=$ heat pump heating seasonal performance factor.

Table 1. Heating and cooling system performance assumptions

\begin{tabular}{|c|c|}
\hline New gas, propane, or oil furnace seasonal efficiency & 0.80 \\
\hline Existing gas, propane, or oil furnace seasonal efficiency & 0.675 \\
\hline New electric air conditioner seasonal energy efficiency ratio (SEER), Btu/W•h & 11 \\
\hline Existing electric air conditioner SEER, Btu/W $\cdot h$ & 9 \\
\hline New heat pump heating seasonal performance factor(HSPF) used in Eq. 1 , Btu/W $\bullet \mathrm{h}$ & 7.5 \\
\hline Existing heat pump HSPF (used in Eq. 1), Btu/W•h & 6.7 \\
\hline New heat pump SEER, Btu/W·h & 10.25 \\
\hline Existing heat pump SEER, Btu/W $\cdot h$ & 9 \\
\hline Electric resistance heat efficiency & 1.0 \\
\hline $\begin{array}{l}\text { Duct efficiency for electric baseboard heating systems (applied to both heating and cooling } \\
\text { energy use) }\end{array}$ & 1.0 \\
\hline Duct efficiency for all other heating systems (applied to both heating and cooling energy use) & 0.75 \\
\hline
\end{tabular}

Ducts were assumed to be located in unconditioned spaces and to have losses of about $25 \% .^{5}$ This assumption is most appropriate for homes with ducts located in the attic and will overpredict energy savings associated with insulation if the ducts are located in the conditioned space. This is discussed later in this report. For baseboard electric heating systems, there were assumed to be no duct losses. 
Changes were made to the ZIP-Code computer program where necessary to reflect changes in the scope of the data used by the program. The two models used to calculate energy savings were unaltered. One of these models was used for insulation measures above-ground and another for measures associated with basements or building foundations. As described in Ref. 3, "Reductions in annual heating requirements and annual cooling requirements due to insulation in attics and in wood-frame and masonry walls are estimated using equations derived from the Lawrence Berkeley Laboratory PEAR ${ }^{6}$ program in support of the proposed ASHRAE 90.2P Standard for the Energy Efficient Design of New Low-Rise Residential Buildings. "." This same approach was used for metal-framed walls and attics, although the thermal conductance (or Uvalues) were calculated more rigorously, as described later in this section, to account for thermal bridging. Equations 2 and 3 and Table 2 show the PEAR-based calculation.

$$
\begin{aligned}
& \Delta Q_{h}=M_{h} \times H D D \times \frac{\Delta U}{1,000,000} \\
& \Delta Q_{c}=M_{c} \times C D H \times \frac{\Delta U}{1,000,000}
\end{aligned}
$$

where: $\Delta \mathrm{Q}_{\mathrm{h}} \quad=\quad$ change in annual heating energy requirement (million $\mathrm{Btu} / \mathrm{ft}^{2} \cdot$ year), $\mathrm{M}_{\mathrm{h}} \quad=\quad$ constant found in Table 2, HDD $=$ heating degree days, base $65^{\circ} \mathrm{F}$, $\Delta \mathrm{U} \quad=\quad$ change in U-value $\left(\mathrm{Btu} /{ }^{\circ} \mathrm{F} \cdot \mathrm{ft}^{2} \cdot\right.$ hour $)$, $\Delta \mathrm{Q}_{\mathrm{c}} \quad=\quad$ annual cooling energy reduction (million Btu/ $\mathrm{ft}^{2} \cdot$ year), $\mathrm{M}_{\mathrm{c}} \quad=\quad$ constant found in Table 2, and $\mathrm{CDH}=$ cooling degree hours, base $74^{\circ} \mathrm{F}$.

Table 2. Constants used to calculate annual energy savings for attics and above-ground walls

\begin{tabular}{|l|c|c|}
\hline \multicolumn{1}{|c|}{ Application } & $\mathbf{M}_{\mathbf{h}}$ & $\mathbf{M}_{\mathbf{c}}$ \\
\hline Attic or cathedral ceiling & 25.91 & 1.978 \\
\hline Frame wall and band joist & 21.19 & 1.005 \\
\hline Masonry wall & 20.02 & 0.739 \\
\hline
\end{tabular}

The model used to estimate savings associated with basement and building foundation insulation was also described in Ref. 3. "The reduction in annual heating requirements and 
annual cooling requirements for floors over unheated spaces, slab floors, and crawlspace and basement walls are estimated using equations and parameters derived from J. Christian and W. Strzepek, 'Procedure for Determining the Optimum Foundation Levels for New, Low-Rise Residential Buildings'. ' Reductions in space heating and cooling requirements per heating degree day and cooling degree hour were estimated in that report at several insulation R-values for floors over unheated areas $\left(\mathrm{Btu} / \mathrm{ft}^{2}\right)$ and for slab floors, crawlspace walls, and exterior and interior insulation of both shallow and deep basement walls (all in Btu/linear foot). Values for other insulation R-values are computed in the ZIP-Code computer program by interpolation (assuming that reductions in thermal loss or gain are proportional to the inverse of the overall thermal resistance of the component)." For each of the components, equations 4 and 5 are used to estimate incremental reductions in annual heating and cooling requirements. The $\beta$ coefficients for these equations are found in Appendix B.

$$
\begin{aligned}
& \Delta Q_{h}=\beta_{h} \times \frac{H D D}{1,000,000} \\
& \Delta Q_{c}=\beta_{c} \times \frac{C D H}{1,000,000}
\end{aligned}
$$

Where: $\Delta \mathrm{Q}_{\mathrm{h}} \quad=\quad$ change in annual heating energy requirement (million $\mathrm{Btu} / \mathrm{ft}^{2} \cdot$ year for floor insulation and million Btu/linear foot $\cdot y e a r$ for other measures),

$\beta_{\mathrm{h}} \quad=\quad$ the reduction in annual heating energy requirement per heating degree day for a designated increase in component $\mathrm{R}$-value, $\Delta \mathrm{Q}_{\mathrm{c}} \quad=\quad$ annual cooling energy reduction (million $\mathrm{Btu} / \mathrm{ft}^{2} \cdot$ year for floor insulation and million Btu/linear foot·year for other measures), and $\beta_{\mathrm{c}}=$ the corresponding reduction in annual cooling requirement per cooling degree hour.

The PEAR-based model used for walls and attics requires the overall U-value associated with each insulation level. Typical wall and attic constructions were assumed to assign values for the base level $U$-values and the improved U-values. These typical constructions were based on ASHRAE guidelines and include internal and external film coefficients. ${ }^{8}$ For these calculations, no pre-existing insulation was assumed and an $\mathrm{R}$-value of $0.9 \mathrm{~h} \bullet \mathrm{ft}^{2} \bullet{ }^{\circ} \mathrm{F} / \mathrm{Btu}$ was used 
for the air space in any wall cavity without insulation. For wood-framed attics and walls, a parallel path heat transfer model was used to include the heat transfer through the framing members in the estimate of the overall U-values.

Heat transfer through studs and joists in metal-framed buildings is of major concern when estimating energy savings associated with insulation applications. The thermal short circuits associated with the more highly conductive metal framing members make cavity insulation options less effective than with wood-framed construction. For metal-framed walls, a modified zone method, similar to that found in the ASHRAE guidelines, was used to account for the heat transfer that occurs through more highly conductive metal frame members. Ghost marks, or dark vertical marks that appear over the framing on the interior surfaces of exterior walls, are likely to occur in moderate and cold climates when metal frames are used without proper attention to the heat transfer that occurs in the framing members. ${ }^{9}$ Because of this concern for metal walls, they were evaluated with a minimum insulation sheathing requirement of 0.5 in., or R2.5, of extruded polystyrene. For both wood- and metal-framed walls, sheathing and cavity insulation were evaluated together as an integrated wall assembly. Sheathing of extruded polystyrene was considered at thicknesses of $0,1 / 2$, and 1 inch, corresponding to R-values of $0,2.5$, and 5 . An alternate sheathing material, foil-faced polyisocyanurate board was also considered at the same thicknesses, corresponding to R-values of $0,3.5$, and 7. (Note that these higher R-values for foilfaced products only apply if the foil-facing is perfectly adhered to the foam and if the foil facing is not damaged before or during the installation process.) For both insulative sheathing materials, it was assumed that the insulation was placed on top of a structural wood sheathing with an $\mathrm{R}$-value of 1.32. This arrangement is used by many builders to avoid the use of bracing and to facilitate exterior siding installation. The wall studs were assigned a thickness of 3.5 inches for cavity insulation of R-15 and below and 5.5 inches for R-21. A short computer program was written to explore these sheathing and cavity insulation options for both wood- and metal-framed walls, as shown in Appendix C. The resulting composite U-values are included later in this report with the cost data for each measure.

The U-values used for metal-framed ceilings in this evaluation were calculated based on experimental work described in Ref. 10. The correlations used are a strong function of the number of interior and edge vertical framing elements that protrude through the insulation. Because there is no "standard" attic truss system, the attic was modeled as a space $30 \times 40 \mathrm{ft}$, with 
joists every $24 \mathrm{in}$. and with a vertical truss connection every $6 \mathrm{ft}$. This produces 84 interior vertical members and 42 edge vertical members over an area of $1200 \mathrm{ft}^{2}$. For this arrangement, the correlations in Ref. 10 show an increase in the overall U-value (compared to a ceiling with no frame at all) of $0.0133 \mathrm{Btu} / \mathrm{h} \cdot \mathrm{ft}^{2}{ }^{\circ} \mathrm{F}$. (The difference between the base, or uninsulated, $\mathrm{U}$-values for the wood- and metal-framed attics shown later in this report appears to be attributable to different assumptions about the air-film resistance. This difference is negligible for insulation levels greater than R-19, which encompass more than $90 \%$ of the cases.) The model also considers the performance of a layer of foam insulation placed between the frame and the ceiling drywall. For cases with foam insulation, the metal-frame increase in the overall U-value is multiplied by a "ceiling foam board adjustment" producing the overall U-values shown later in this report with the cost data. The author of Ref. 10 points out that these correlations neglect heat loss associated with the extension of the attic joists into the eaves, which provides a direct path for heat transfer from the ceiling to the outdoor air.

A metal-framed floor conducts more heat than a wood-framed floor, as is shown by the equivalent metal-floor $R$-values given in Ref. 10. Corresponding $\beta$ coefficients used to calculate the savings for a metal-framed floor (see Eqs. 4 and 5) were interpolated from those provided in Ref. 7 by assuming that reductions in thermal loss or gain are proportional to the inverse of the overall thermal resistance. For this interpolation, the overall R-values of the floors were used, as shown in Table 3. The base level resistance (without any insulation in place) was assumed to be the same for both wood and metal floors, because there was no experimental data on the uninsulated metal floor.

Table 3. Interpolation of heating season savings factors for metal-framed floors

\begin{tabular}{|c|c|c|c|c|c|c|}
\hline \multirow{2}{*}{$\begin{array}{c}\text { Cavity insulation } \\
\text { R-value }\end{array}$} & \multicolumn{2}{|c|}{ System R-value } & \multicolumn{2}{c|}{ System U-value } & \multicolumn{2}{c|}{ Saving factor $(\beta)$} \\
\cline { 2 - 8 } & Wood & Metal & Wood & Metal & Wood & Metal \\
\hline 0 & 4 & 4 & .249 & .249 & & \\
\hline 11 & 13.9 & 7.3 & .072 & .14 & 1.7 & 1.05 \\
\hline 19 & 21 & 8.9 & .047 & .11 & 1.96 & 1.33 \\
\hline 30 & 30 & 11.0 & .033 & .091 & 2.22 & 1.52 \\
\hline
\end{tabular}




\section{Insulation Costs}

Insulation measures were considered for each type of house, new or existing, based on current market practices. For new construction, these included insulation in the attic, on the interior surface of masonry walls, underneath floors over crawl spaces, along the perimeter of the slab edge, on the interior wall of an unvented crawlspace, on the interior or exterior of a basement wall, within a cathedral ceiling, along the band joists between floors, and a combination of insulative sheathing and cavity insulation for wood- and metal-frame walls. For existing houses, fewer insulation measures were considered, because several measures are difficult to install after construction is complete. Insulative sheathing was considered for existing houses under renovation. Some possible insulation applications were not considered for the DOE Insulation Fact Sheet because alternative treatments proved to be less costly. For example, crawl space walls can be insulated on the inside or outside surface. The inside treatment cost estimates were lower than the outside costs, so the inside application was included in the fact sheet and the outside one was not. For attics, the installed cost of loose fill insulation was less than that of batt insulation products, so loose fill costs were used to derive the recommended levels. For new construction, batt products were the least expensive method for wall insulation, whereas blown-in products were less costly for existing walls.

A survey was made to determine appropriate costs for the analysis. The aim of the survey was to obtain costs from 60 insulation contractors for both new construction and retrofit applications, and from at least 60 building contractors able to provide cost information representative of new construction. Over 2000 insulation contractors and over 1000 builders were selected at random across the United States and were contacted by phone. Approximately $18 \%$ of the contractors agreed to return the survey, but only $9 \%$ of these (or less than $2 \%$ of the original 2000 who were polled) actually returned the survey, despite a series of follow-up contacts by phone, fax, and mail. Out of the all the builders contacted, only 18 responded to the survey.

The survey participants were asked to provide installed costs, including materials, labor, overhead, and profit for a variety of insulation applications. They were asked to provide estimates separately for new construction and existing houses. Appendix D shows the survey forms used to collect data from the participants. A large number of contractors provided prices for common attic, wall, and floor insulation jobs. However, they provided very few estimates for 
other applications, such as masonry wall insulation.

Builders were asked to provide incremental framing costs associated with higher levels of insulation in cathedral ceilings and wood-frame walls. These forms are also shown in Appendix D. Tables 4 and 5 summarize the survey, showing the number of responses, and the mean and standard deviation for the values reported. The mean values were used to represent national average costs for the ZIP-Code computer program. When the 1988 cost files were updated, it was noted that most insulation costs had remained very nearly the same. Some costs were even slightly lower than those quoted in 1988 , despite the modest inflation that has occurred during the last eight years. Therefore, for those insulation applications where the new data were insufficient, the 1988 cost figures were retained for this analysis. Additional cost survey data compilations are included in Appendix D.

Table 4. Insulation contractor survey results

\begin{tabular}{|c|c|c|c|c|}
\hline Material & $\begin{array}{c}\mathbf{R}- \\
\text { value }\end{array}$ & $\begin{array}{l}\text { Mean installed } \\
\text { cost }\left(\$ / \mathrm{ft}^{2}\right)\end{array}$ & $\begin{array}{l}\text { Number of } \\
\text { responses }\end{array}$ & $\begin{array}{c}\text { Standard } \\
\text { Deviation }\left(\$ / \mathrm{ft}^{2}\right)\end{array}$ \\
\hline \multicolumn{5}{|c|}{ New construction: attic floor } \\
\hline Fiberglass blanket & 11 & .33 & 25 & .10 \\
\hline Blown fiberglass & 11 & .24 & 20 & .06 \\
\hline Blown cellulose & 11 & .27 & 14 & .12 \\
\hline Blown rockwool & 11 & .21 & 7 & .04 \\
\hline Average blown material & 11 & .24 & 41 & .09 \\
\hline Fiberglass blanket & 19 & .44 & 25 & .10 \\
\hline Blown fiberglass & 19 & .33 & 24 & .07 \\
\hline Blown cellulose & 19 & .34 & 16 & .12 \\
\hline Blown rockwool & 19 & .29 & 7 & .06 \\
\hline Average blown material & 19 & .33 & 47 & .09 \\
\hline Fiberglass blanket & 22 & .58 & 15 & .18 \\
\hline Blown fiberglass & 22 & .35 & 15 & .06 \\
\hline Blown cellulose & 22 & .41 & 15 & .15 \\
\hline Blown rockwool & 22 & .32 & 7 & .06 \\
\hline Average blown material & 22 & .37 & 37 & .11 \\
\hline Fiberglass blanket & 25 & .66 & 9 & .24 \\
\hline Fiberglass blanket & 30 & .62 & 24 & .13 \\
\hline
\end{tabular}


Table 4. Insulation contractor survey results (cont.)

\begin{tabular}{|c|c|c|c|c|}
\hline Material & $\begin{array}{c}\mathbf{R}- \\
\text { value }\end{array}$ & $\begin{array}{c}\text { Mean installed } \\
\text { cost }\left(\$ / \mathbf{f t}^{2}\right)\end{array}$ & $\begin{array}{l}\text { Number of } \\
\text { responses }\end{array}$ & $\begin{array}{c}\text { Standard } \\
\text { Deviation }\left(\$ / \mathrm{ft}^{2}\right)\end{array}$ \\
\hline Blown fiberglass & 30 & .44 & 23 & .08 \\
\hline Blown cellulose & 30 & .47 & 17 & .13 \\
\hline Blown rockwool & 30 & .42 & 7 & .08 \\
\hline Average blown material & 30 & .45 & 47 & .10 \\
\hline Fiberglass blanket & 38 & .74 & 23 & .15 \\
\hline Blown fiberglass & 38 & .55 & 21 & .10 \\
\hline Blown cellulose & 38 & .57 & 20 & .13 \\
\hline Blown rockwool & 38 & .52 & 7 & .11 \\
\hline Average blown material & 38 & .56 & 48 & .11 \\
\hline Fiberglass blanket & 49 & 1.17 & 6 & .28 \\
\hline Blown fiberglass & 49 & .68 & 10 & .16 \\
\hline Blown cellulose & 49 & .70 & 13 & .15 \\
\hline Blown rockwool & 49 & .66 & 6 & .16 \\
\hline Average blown material & 49 & .68 & 29 & .15 \\
\hline Fiberglass blanket & 60 & 1.41 & 6 & .34 \\
\hline Blown fiberglass & 60 & .84 & 10 & .19 \\
\hline Blown cellulose & 60 & .81 & 12 & .19 \\
\hline Blown rockwool & 60 & .82 & 6 & .21 \\
\hline Average blown material & 60 & .82 & 28 & .19 \\
\hline \multicolumn{5}{|c|}{ Existing house: attic floor } \\
\hline Fiberglass blanket & 11 & .35 & 24 & .08 \\
\hline Blown fiberglass & 11 & .26 & 24 & .08 \\
\hline Blown cellulose & 11 & .31 & 16 & .12 \\
\hline Blown rockwool & 11 & .22 & 9 & .05 \\
\hline Average blown material & 11 & .27 & 49 & .10 \\
\hline Fiberglass blanket & 19 & .49 & 27 & .11 \\
\hline Blown fiberglass & 19 & .35 & 27 & .08 \\
\hline Blown cellulose & 19 & .41 & 22 & .13 \\
\hline Blown rockwool & 19 & .31 & 49 & .07 \\
\hline
\end{tabular}


Table 4. Insulation contractor survey results (cont.)

\begin{tabular}{|c|c|c|c|c|}
\hline Material & $\begin{array}{c}\mathrm{R}- \\
\text { value }\end{array}$ & $\begin{array}{l}\text { Mean installed } \\
\text { cost }\left(\$ / \mathbf{f t}^{2}\right)\end{array}$ & $\begin{array}{l}\text { Number of } \\
\text { responses }\end{array}$ & $\begin{array}{c}\text { Standard } \\
\text { Deviation }\left(\$ / \mathbf{f t}^{2}\right)\end{array}$ \\
\hline Average blown material & 19 & .37 & 58 & .11 \\
\hline Fiberglass blanket & 22 & .65 & 15 & .16 \\
\hline Fiberglass blanket & 25 & .71 & 15 & .23 \\
\hline Fiberglass blanket & 30 & .67 & 23 & .13 \\
\hline Blown fiberglass & 30 & .48 & 27 & .10 \\
\hline Blown cellulose & 30 & .52 & 21 & .10 \\
\hline Blown rockwool & 30 & .45 & 9 & .10 \\
\hline Average blown material & 30 & .49 & 57 & .10 \\
\hline Fiberglass blanket & 38 & .84 & 20 & .22 \\
\hline Blown fiberglass & 38 & .60 & 24 & .11 \\
\hline Blown cellulose & 38 & .62 & 23 & .10 \\
\hline Blown rockwool & 38 & .59 & 8 & .11 \\
\hline Average blown material & 38 & .60 & 55 & .10 \\
\hline Fiberglass blanket & 49 & 1.07 & 9 & .32 \\
\hline Blown fiberglass & 49 & .77 & 14 & .14 \\
\hline Blown cellulose & 49 & .78 & 18 & .13 \\
\hline Blown rockwool & 49 & .75 & 7 & .16 \\
\hline Average blown material & 49 & .77 & 39 & .14 \\
\hline \multicolumn{5}{|c|}{ New construction: cathedral ceiling } \\
\hline Fiberglass blanket & 11 & .34 & 19 & .10 \\
\hline Fiberglass blanket & 13 & .46 & 21 & .22 \\
\hline Fiberglass blanket & 15 & .63 & 17 & .11 \\
\hline Fiberglass blanket & 19 & .53 & 24 & .25 \\
\hline Fiberglass blanket & 21 & .62 & 14 & .12 \\
\hline Fiberglass blanket & 22 & .59 & 11 & .20 \\
\hline Fiberglass blanket & 30 & .73 & 25 & .36 \\
\hline Fiberglass blanket & 38 & .87 & 24 & .43 \\
\hline Fiberglass blanket & 49 & 1.10 & 6 & .35 \\
\hline Fiberglass blanket & 60 & 1.24 & 6 & .47 \\
\hline
\end{tabular}


Table 4. Insulation contractor survey results (cont.)

\begin{tabular}{|c|c|c|c|c|}
\hline Material & $\begin{array}{c}\mathrm{R}- \\
\text { value }\end{array}$ & $\begin{array}{c}\text { Mean installed } \\
\text { cost }\left(\$ / f^{2}\right)\end{array}$ & $\begin{array}{c}\text { Number of } \\
\text { responses }\end{array}$ & $\begin{array}{c}\text { Standard } \\
\text { Deviation }\left(\$ / \mathbf{f t}^{2}\right)\end{array}$ \\
\hline \multicolumn{5}{|c|}{ New construction: exterior walls } \\
\hline Fiberglass blanket & 11 & .31 & 22 & .09 \\
\hline Fiberglass blanket & 13 & .37 & 23 & .09 \\
\hline Fiberglass blanket & 15 & .56 & 21 & .11 \\
\hline Fiberglass blanket & 19 & .44 & 23 & .11 \\
\hline Fiberglass blanket & 21 & .55 & 14 & .11 \\
\hline Insulative sheathing & 3 & .40 & 1 & 0 \\
\hline Insulative sheathing & 4 & .52 & 2 & .12 \\
\hline Insulative sheathing & 5 & .64 & 1 & 0 \\
\hline Insulative sheathing & 7 & .67 & 2 & .15 \\
\hline Insulative sheathing & 8 & .80 & 1 & 0 \\
\hline Insulative sheathing & 10 & .77 & 2 & .18 \\
\hline Sprayed cellulose & 12 & .67 & 8 & .22 \\
\hline Sprayed cellulose & 19 & .80 & 8 & .25 \\
\hline \multicolumn{5}{|c|}{ Existing house: exterior walls } \\
\hline Cellulose $\left(3 \mathrm{lb} / \mathrm{ft}^{3}\right)$ & 11 & .76 & 18 & .28 \\
\hline Cellulose $\left(4 / \mathrm{lb} / \mathrm{ft}^{3}\right)$ & 11 & .86 & 14 & .30 \\
\hline Blown fiberglass & 11 & .80 & 14 & .32 \\
\hline \multicolumn{5}{|c|}{ New construction: floor } \\
\hline Fiberglass blanket & 11 & .37 & 20 & .12 \\
\hline Fiberglass blanket & 13 & .41 & 19 & .09 \\
\hline Fiberglass blanket & 15 & .61 & 17 & .08 \\
\hline Fiberglass blanket & 19 & .53 & 24 & .16 \\
\hline Fiberglass blanket & 25 & .62 & 7 & .12 \\
\hline \multicolumn{5}{|c|}{ Existing house: floor } \\
\hline Fiberglass blanket & 11 & .38 & 25 & .11 \\
\hline Fiberglass blanket & 13 & .46 & 24 & .15 \\
\hline Fiberglass blanket & 15 & .61 & 19 & .11 \\
\hline Fiberglass blanket & 19 & .58 & 32 & .20 \\
\hline
\end{tabular}


Table 4. Insulation contractor survey results (cont.)

\begin{tabular}{|c|c|c|c|c|}
\hline Material & $\begin{array}{c}\text { R- } \\
\text { value }\end{array}$ & $\begin{array}{l}\text { Mean installed } \\
\text { cost }\left(\$ / \mathrm{ft}^{2}\right)\end{array}$ & $\begin{array}{l}\text { Number of } \\
\text { responses }\end{array}$ & $\begin{array}{c}\text { Standard } \\
\text { Deviation }\left(\$ / \mathrm{ft}^{2}\right)\end{array}$ \\
\hline Fiberglass blanket & 25 & .76 & 13 & .36 \\
\hline \multicolumn{5}{|c|}{ New construction: concrete/block walls - exterior and below grade } \\
\hline Fiberglass blanket & 5 & .42 & 1 & 0 \\
\hline Fiberglass blanket & 10 & .45 & 3 & .02 \\
\hline Fiberglass blanket & 15 & .56 & 8 & .11 \\
\hline Fiberglass blanket & 20 & .66 & 1 & 0 \\
\hline \multicolumn{5}{|c|}{ New construction: crawl space wall - interior application } \\
\hline Fiberglass blanket & 11 & .37 & 21 & .13 \\
\hline Fiberglass blanket & 13 & .41 & 20 & .11 \\
\hline Fiberglass blanket & 15 & .59 & 19 & .11 \\
\hline Fiberglass blanket & 19 & .52 & 22 & .15 \\
\hline Extruded polystyrene & 10 & .98 & 1 & 0 \\
\hline \multicolumn{5}{|c|}{ Existing house: crawl space wall - interior application } \\
\hline Fiberglass blanket & 11 & .37 & 25 & .12 \\
\hline Fiberglass blanket & 13 & .44 & 23 & .16 \\
\hline Fiberglass blanket & 15 & .59 & 20 & .13 \\
\hline Fiberglass blanket & 19 & .55 & 26 & .19 \\
\hline Extruded polystyrene & 7 & .72 & 1 & 0 \\
\hline Extruded polystyrene & 10 & .90 & 1 & 0 \\
\hline Extruded polystyrene & 15 & 1.05 & 1 & 0 \\
\hline Extruded polystyrene & 19 & 1.15 & 1. & 0 \\
\hline \multicolumn{5}{|c|}{ Band Joist } \\
\hline Fiberglass blanket & 11 & .31 & 22 & .09 \\
\hline Fiberglass blanket & 13 & .36 & 21 & .08 \\
\hline Fiberglass blanket & 19 & .45 & 24 & .10 \\
\hline Fiberglass blanket & 30 & .60 & 18 & .09 \\
\hline \multicolumn{5}{|c|}{ New construction: masonry walls } \\
\hline Insulating stucco over fiberglass & 11 & .31 & 2 & .01 \\
\hline Insulating stucco over fiberglass & 13 & .38 & 2 & .03 \\
\hline
\end{tabular}


Table 4. Insulation contractor survey results (cont.)

\begin{tabular}{|c|c|c|c|c|}
\hline Material & $\begin{array}{c}\text { R- } \\
\text { value }\end{array}$ & $\begin{array}{l}\text { Mean installed } \\
\text { cost }\left(\$ / \mathrm{ft}^{2}\right)\end{array}$ & $\begin{array}{l}\text { Number of } \\
\text { responses }\end{array}$ & $\begin{array}{c}\text { Standard } \\
\text { Deviation }\left(\$ / \mathrm{ft}^{2}\right)\end{array}$ \\
\hline Insulating stucco over fiberglass & 19 & .43 & 2 & .04 \\
\hline Isocyanurate foam in block cavity & 14 & 1.92 & 1 & 0 \\
\hline Isocyanurate foam in block cavity & 25 & 2.81 & 1 & 0 \\
\hline \multicolumn{5}{|c|}{ New construction: concrete/block walls - interior application above- or below-grade } \\
\hline Fiberglass blanket & 11 & .34 & 16 & .14 \\
\hline Fiberglass blanket & 13 & .40 & 13 & .11 \\
\hline Fiberglass blanket & 15 & .56 & 10 & .14 \\
\hline Fiberglass blanket & 19 & .47 & 15 & .15 \\
\hline Fiberglass batts with flame-resistant facing & 11 & .52 & 10 & .20 \\
\hline Expanded polystyrene & 5 & .80 & 1 & 0 \\
\hline Expanded polystyrene & 7 & .70 & 1 & 0 \\
\hline
\end{tabular}

Framing costs from Table 5 were included in the costs used in this analysis for wood- and metal-framed walls at higher insulation levels. The total framing costs shown in Table 5 have been calculated from the incremental costs requested from the builders (see the forms in Appendix D). Data were not collected for metal-framed walls. Additional framing costs for all wall thicknesses greater than 3.5 inches were estimated to be $\$ 0.83 / \mathrm{ft}^{2}$ for both wood and metal, based on the builder estimates for wood frame construction. No data were collected for Optimum Value Engineered (OVE) framing costs. The evaluation of insulation options for OVE construction was based on the assumption that a $2 \times 6$ wall could be built for the same cost as a conventional $2 \times 4$ wall, i.e., no framing costs were associated with the higher levels of insulation. Note that this assumption indicates that the cost of extension jambs for windows and doors has also been offset during the OVE design process.

Framing costs from Table 5 were originally used for cathedral ceiling insulation levels greater than R-19. However, many reviewers argued that additional framing costs for cathedral ceilings were inappropriate. A series of phone consultations with major builders supported these comments. The builders reported typically using an engineered truss system with more than six inches of space for insulation. Therefore, the cathedral ceiling analysis assumed that no additional framing costs were associated with insulation values up to R-38. 
Table 5. Builder survey results

\begin{tabular}{|c|c|c|c|}
\hline R-value & Mean cost $\left(\$ / \mathrm{ft}^{2}\right)$ & Number of responses & Standard deviation $\left(\$ / \mathbf{f t}^{2}\right)$ \\
\hline \multicolumn{4}{|c|}{ Raised heel attic framing } \\
\hline 22 & .08 & 6 & .04 \\
\hline 30 & .18 & 9 & .09 \\
\hline 38 & .28 & 11 & .18 \\
\hline 49 & .42 & 9 & .25 \\
\hline 60 & .62 & 9 & .41 \\
\hline \multicolumn{4}{|c|}{ Cathedral ceiling framing } \\
\hline 19 & .14 & 4 & .11 \\
\hline 22 & .20 & 5 & .15 \\
\hline 30 & .41 & 9 & .30 \\
\hline 38 & .60 & 7 & .42 \\
\hline 49 & .92 & 6 & .68 \\
\hline 60 & 1.04 & 5 & .84 \\
\hline \multicolumn{4}{|c|}{ Wood frame walls, increased costs for changing from $2 \times 4$ to $2 \times 6$ construction } \\
\hline$>15$ & .83 & 15 & .72 \\
\hline \multicolumn{4}{|c|}{ Concrete-block wall, interior framing for insulation } \\
\hline 7.5 & .97 & 12 & .71 \\
\hline 10 & 1.19 & 12 & .66 \\
\hline 15 & 1.56 & 12 & .91 \\
\hline 19 & 1.78 & 12 & 1.04 \\
\hline
\end{tabular}

When builder-reported costs for raised heel framing were used to estimate savings for attics in new construction, the recommended insulation levels were much lower than for existing houses. In existing houses, the average savings coefficients based on the PEAR analysis are used, even though it is assumed that the higher insulation levels will be installed only over those parts of the attic floor with adequate clearance. Comparing these two conflicting results, it was deemed more conservative to neglect the raised heel framing costs for new construction, thereby using the retrofit assumption that the additional insulation will only be placed over those parts of the attic floor with adequate clearance. 
For insulative sheathing, the builders were asked to report the incremental cost incurred when insulative sheathing is used to replace fiberboard on a $900 \mathrm{ft}^{2}$ wall for $\mathrm{R}$-values ranging from 3.6 to 10 . The responses ranged from $\$ 0$ to $\$ 550$. Examination of the answers revealed three sets of answers that appeared to correspond to estimates for: (1)the whole $900 \mathrm{ft}^{2}$, (2)each $4 \times 8$ sheet of sheathing, and (3) each square foot. Scatter within these groups probably reflects differences in building practices, because some builders routinely place foam sheathing on top of wood sheathing while other use it to replace the sheathing and add necessary bracing to the frame. Yet another technique is to use the foam sheathing for portions of the walls where strength is not important and to use wood sheathing near corners where the bracing is needed. Follow-up phone calls to these builders were not returned and these quoted prices were therefore not used. An additional effort was made to collect retail costs for 1 and 2 -in. (R-5 and R-10) sheets of extruded polystyrene. This small survey, where home supply stores in 14 states were polled, is summarized in Table 6. The cost of insulative wall sheathing was estimated using this survey to represent material costs, which were then combined with labor, overhead, and profit from 1996 R.S. Means. ${ }^{11}$ These costs showed reasonable agreement to the few insulation contractor-reported costs for insulative sheathing gathered during the 1996 cost survey, and were therefore used in the wall insulation analysis. Foil-faced polyisocyanurate is another potential wall sheathing material and has a nominal R-value of R7 per inch. (Note that the higher Rvalues for foil-faced products only apply if the foil-facing is perfectly adhered to the foam and if the foil facing is not damaged before or during the installation process.) Installed costs for this sheathing were taken from a Polyisocyanurate Insulation Manufacturers' Association (PIMA) case study and are $\$ .65 / \mathrm{ft}^{2}$ for $1 / 2$ inch and $\$ .87 / \mathrm{ft}^{2}$ for one inch. ${ }^{22}$

Table 6. Retail prices for extruded polystyrene from 14 states

\begin{tabular}{|c|c|c|c|c|c|}
\hline R-value & $\begin{array}{l}\text { Number of } \\
\text { responses }\end{array}$ & $\begin{array}{l}\text { Mean } \\
\left(\$ / \mathbf{f t}^{2}\right) \\
\end{array}$ & $\begin{array}{c}\text { Standard } \\
\text { deviation }\left(\$ / \mathrm{ft}^{2}\right)\end{array}$ & $\underset{\left(\$ / \mathbf{f t}^{2}\right)}{\operatorname{Minimum}}$ & $\begin{array}{c}\text { Maximum } \\
\left(\$ / \mathrm{ft}^{2}\right)\end{array}$ \\
\hline 5 & 14 & 0.25 & 0.09 & 0.14 & 0.40 \\
\hline 10 & 15 & 0.45 & 0.14 & 0.24 & 0.66 \\
\hline
\end{tabular}

The ZIP-Code computer program used regional cost multipliers to adjust insulation costs for differences in material and labor costs. These factors were updated using RS Means city factors ( -300 cities) for "thermal and moisture protection", averaged into state factors. ${ }^{11}$ These 
state cost correction factors, normalized to 100 for the national average, have been included in Appendix E.

The results of the cost survey, combined with the composite U-values described previously, are summarized in Table 7.

Table 7. Insulation costs and thermal resistances used in the ZIP-Code computer program

\begin{tabular}{|c|c|c|c|c|}
\hline \multirow{2}{*}{\multicolumn{2}{|c|}{$\begin{array}{c}\text { Added insulation } \\
\left.\mathrm{R} \text {-value (h-ft } \mathbf{f t}^{2}-\mathrm{F} / \mathrm{Btu}\right)\end{array}$}} & \multirow{2}{*}{$\begin{array}{l}\text { Overall component } \mathrm{U} \text {-value } \\
\left(\text { (Btu/ }^{\circ} \mathbf{F} \cdot \mathrm{ft}^{2} \cdot \mathbf{h}\right)\end{array}$} & \multicolumn{2}{|c|}{ Cost $\left(\$ / \mathrm{ft}^{2}\right.$ or $\$$ /linear $\left.\mathrm{ft}\right)$} \\
\hline & & & New construction & Existing \\
\hline \multicolumn{5}{|c|}{ Wood-framed attic $\left(\$ / \mathrm{ft}^{2}\right)$} \\
\hline \multicolumn{2}{|c|}{0} & 0.2540 & & \\
\hline \multicolumn{2}{|c|}{11} & 0.0688 & 0.24 & .27 \\
\hline \multicolumn{2}{|c|}{19} & 0.0455 & 0.33 & .37 \\
\hline \multicolumn{2}{|c|}{22} & 0.0400 & 0.37 & \\
\hline \multicolumn{2}{|c|}{30} & 0.0333 & 0.45 & .49 \\
\hline \multicolumn{2}{|c|}{38} & 0.0241 & 0.56 & .60 \\
\hline \multicolumn{2}{|c|}{49} & 0.0199 & 0.68 & .77 \\
\hline \multicolumn{2}{|c|}{60} & 0.0193 & 0.82 & \\
\hline \multicolumn{5}{|c|}{ Metal-framed attic $\left(\$ / \mathrm{ft}^{2}\right)$} \\
\hline Sheathing & Cavity & & & \\
\hline none & 0 & 0.592 & & \\
\hline none & 11 & 0.092 & 0.24 & \\
\hline none & 19 & 0.062 & 0.33 & \\
\hline none & 30 & 0.045 & 0.45 & \\
\hline none & 38 & 0.039 & 0.56 & \\
\hline none & 49 & 0.033 & 0.68 & \\
\hline 5 & 38 & 0.028 & 1.14 & \\
\hline 5 & 49 & 0.023 & 1.26 & \\
\hline 10 & 49 & 0.020 & 1.53 & \\
\hline \multicolumn{5}{|c|}{ Cathedral ceiling $\left(\$ / \mathrm{ft}^{2}\right)$} \\
\hline \multicolumn{2}{|c|}{0} & 0.2616 & & \\
\hline \multicolumn{2}{|c|}{11} & 0.0742 & .34 & \\
\hline
\end{tabular}


Table 7. Insulation costs and thermal resistances used in the ZIP-Code computer program(cont.)

\begin{tabular}{|c|c|c|c|}
\hline \multirow{2}{*}{$\begin{array}{c}\text { Added insulation } \\
\mathrm{R} \text {-value (h-ft'-F/Btu) }\end{array}$} & \multirow{2}{*}{$\begin{array}{l}\text { Overall component U-value } \\
\qquad\left(\mathrm{Btu} /{ }^{\circ} \mathbf{F} \cdot \mathrm{ft}^{2} \cdot \mathbf{h}\right)\end{array}$} & \multicolumn{2}{|c|}{ Cost $\left(\$ / f^{2}\right.$ or $\$$ linear $\left.f t\right)$} \\
\hline & & New construction & Existing \\
\hline 13 & 0.0666 & .46 & \\
\hline 15 & 0.0607 & .63 & \\
\hline 19 & 0.0493 & .53 & \\
\hline 21 & 0.0460 & .62 & \\
\hline 22 & 0.0434 & .59 & \\
\hline 30 & 0.0332 & .73 & \\
\hline 38 & 0.0270 & .87 & \\
\hline 49 & 0.0216 & 2.02 & \\
\hline 60 & 0.0178 & 2.29 & \\
\hline \multicolumn{4}{|c|}{ Masonry Walls $\left(\$ / \mathrm{ft}^{2}\right)$} \\
\hline 0 & 0.263 & & \\
\hline 3.8 & 0.164 & 0.22 & \\
\hline 5.7 & 0.130 & 0.36 & \\
\hline 7.6 & 0.108 & 0.52 & \\
\hline 9.5 & 0.092 & 0.67 & \\
\hline 11.4 & 0.080 & 0.82 & \\
\hline 15.0 & 0.068 & 1.78 & \\
\hline 21.6 & 0.056 & 2.20 & \\
\hline \multicolumn{4}{|c|}{ Wood-or metal-framed floor $\left(\$ / \mathrm{ft}^{2}\right)$} \\
\hline 11 & not used & 0.37 & .38 \\
\hline 13 & not used & 0.41 & .46 \\
\hline 19 & not used & 0.53 & .58 \\
\hline 25 & not used & 0.62 & .76 \\
\hline \multicolumn{4}{|c|}{ Slab edge ( $\$$ /linear foot) } \\
\hline 4 & not used & 1.40 & \\
\hline 8 & not used & 1.82 & \\
\hline \multicolumn{4}{|c|}{ Crawl space walls (\$/linear foot) } \\
\hline 11 & not used & 1.47 & 1.49 \\
\hline
\end{tabular}


Table 7. Insulation costs and thermal resistances used in the ZIP-Code computer program(cont.)

\begin{tabular}{|c|c|c|c|}
\hline \multirow{2}{*}{$\begin{array}{l}\text { Added insulation } \\
\text { R-value (h-ft'-F/Btu) }\end{array}$} & \multirow{2}{*}{$\begin{array}{l}\text { Overall component U-value } \\
\left(\mathrm{Btu} /{ }^{\circ} \mathrm{F} \cdot \mathrm{ft}^{2} \cdot \mathrm{h}\right)\end{array}$} & \multicolumn{2}{|c|}{ Cost $\left(\$ / \mathrm{ft}^{2}\right.$ or $\$ /$ linear $\left.\mathrm{ft}\right)$} \\
\hline & & New construction & Existing \\
\hline 13 & not used & 1.63 & 1.75 \\
\hline 19 & not used & $2.08^{\circ}$ & 2.19 \\
\hline \multicolumn{4}{|c|}{ Basement walls - exterior application (\$/linear foot) } \\
\hline 4 & not used & 6.20 & \\
\hline 5 & not used & 7.01 & \\
\hline 8 & not used & 9.30 & \\
\hline 10 & not used & 10.87 & \\
\hline 12 & not used & 12.30 & \\
\hline 15 & not used & 14.55 & \\
\hline \multicolumn{4}{|c|}{ Basement walls - interior application (\$/linear foot) } \\
\hline $11^{\mathrm{a}}$ & not used & 4.24 & 4.24 \\
\hline 11 & not used & 6.48 & 6.48 \\
\hline 13 & not used & 7.20 & 7.20 \\
\hline 19 & not used & 9.30 & 9.30 \\
\hline \multicolumn{4}{|c|}{ Band joist (\$/linear foot) } \\
\hline 0 & 0.197 & & \\
\hline 11 & 0.065 & 0.31 & \\
\hline 13 & 0.059 & 0.36 & \\
\hline 19 & 0.044 & 0.45 & \\
\hline 30 & 0.031 & 0.60 & \\
\hline \multicolumn{4}{|c|}{ Add insulative sheathing to uninsulated exterior wall $\left(\$ / \mathrm{ft}^{2}\right)$} \\
\hline 0 & 0.204 & & \\
\hline 2.5 & .134 & & .47 \\
\hline 5. & .1 & & .58 \\
\hline \multicolumn{4}{|c|}{ Add insulative sheathing to wall with $\mathrm{R}-11$ cavity insulation ${ }^{\mathrm{b}}\left(\$ / \mathrm{ft}^{2}\right)$} \\
\hline 0 & 0.084 & & \\
\hline 2.5 & 0.068 & & .47 \\
\hline 5. & 0.058 & & .58 \\
\hline
\end{tabular}


Table 7. Insulation costs and thermal resistances used in the ZIP-Code computer program(cont.)

\begin{tabular}{|c|c|c|c|c|}
\hline \multirow{2}{*}{\multicolumn{2}{|c|}{$\begin{array}{c}\text { Added insulation } \\
\left.\text { R-value (h-ft } \mathrm{ft}^{2}-\mathrm{F} / \mathrm{Btu}\right)\end{array}$}} & \multirow{2}{*}{$\begin{array}{l}\text { Overall component U-value } \\
\left(\left(\mathbf{B t u} /{ }^{\circ} \mathbf{F} \cdot \mathbf{f t}^{2} \cdot \mathbf{h}\right)\right.\end{array}$} & \multicolumn{2}{|c|}{ Cost $\left(\$ / \mathrm{ft}^{2}\right.$ or $\$$ /linear $\left.\mathrm{ft}\right)$} \\
\hline & & & New construction & Existing \\
\hline \multicolumn{5}{|c|}{ Wood-framed wall - combined insulative sheathing and cavity insulation $\left(\$ / \mathrm{ft}^{2}\right)$} \\
\hline Sheathing & Cavity & & & \\
\hline 0 & none & 0.2052 & & \\
\hline 2.5 & 11 & .0686 & .77 & \\
\hline 3.5 & 11 & 0.0639 & .95 & \\
\hline 2.5 & 13 & .0639 & .83 & \\
\hline 3.5 & 13 & .0597 & 1.01 & \\
\hline 2.5 & 15 & .0601 & 1.03 & \\
\hline 3.5 & 15 & .0563 & 1.21 & \\
\hline 2.5 & 19 & .0496 & 1.74 & \\
\hline 3.5 & 19 & .0470 & 1.92 & \\
\hline 2.5 & 21 & .0474 & 1.85 & \\
\hline 3.5 & 21 & .0450 & 2.03 & \\
\hline 5 & 11 & .0581 & .88 & \\
\hline 7 & 11 & .0519 & 1.17 & \\
\hline 5 & 13 & .0545 & .94 & \\
\hline 7 & 13 & .0489 & 1.23 & \\
\hline 5 & 15 & .0515 & 1.14 & \\
\hline 7 & 15 & .0464 & 1.43 & \\
\hline 5 & 19 & .0437 & 1.85 & \\
\hline 7 & 19 & .0399 & 2.14 & \\
\hline 5 & 21 & .0418 & 1.96 & \\
\hline 7 & 21 & .0383 & 2.25 & \\
\hline none & 11 & .0840 & .30 & .80 \\
\hline none & 13 & .0777 & .36 & \\
\hline none & 15 & .0727 & .56 & \\
\hline none & 19 & .0577 & 1.27 & \\
\hline none & 21 & .0550 & 1.38 & \\
\hline
\end{tabular}


Table 7. Insulation costs and thermal resistances used in the ZIP-Code computer program(cont.)

\begin{tabular}{|c|c|c|c|c|}
\hline \multirow{2}{*}{\multicolumn{2}{|c|}{$\begin{array}{c}\text { Added insulation } \\
\text { R-value (h-ft'-F/Btu) }\end{array}$}} & \multirow{2}{*}{$\begin{array}{l}\text { Overall component U-value } \\
\left(\mathbf{B t u} /{ }^{\circ} \mathbf{F} \cdot \mathrm{ft}^{2} \cdot h\right)\end{array}$} & \multicolumn{2}{|c|}{ Cost $\left(\$ / \mathrm{ft}^{2}\right.$ or $\$ /$ linear $\left.\mathrm{ft}\right)$} \\
\hline & & & New construction & Existing \\
\hline Sheathing & Cavity & & & \\
\hline 2.5 & none & .1341 & .47 & \\
\hline 3.5 & none & .1179 & .65 & \\
\hline 5 & none & .0999 & .58 & \\
\hline 7 & none & .0831 & .87 & \\
\hline \multicolumn{5}{|c|}{ Metal-framed wall - combined insulative sheathing and cavity insulation $\left(\$ / \mathrm{ft}^{2}\right)$} \\
\hline Sheathing & Cavity & & & \\
\hline none & none & .2362 & & \\
\hline 2.5 & none & .1486 & .47 & \\
\hline 3.5 & none & .1293 & .65 & \\
\hline 5 & none & .1084 & .58 & \\
\hline 7 & none & .0891 & .87 & \\
\hline none & 11 & .1049 & not used & \\
\hline none & 13 & .0988 & not used & \\
\hline none & 15 & .0942 & not used & \\
\hline none & 19 & .0864 & not used & \\
\hline none & 21 & .0841 & not used & \\
\hline 2.5 & 11 & .0808 & .77 & \\
\hline 3.5 & 11 & .0731 & .95 & \\
\hline 2.5 & 13 & .0766 & .83 & \\
\hline 3.5 & 13 & .0693 & 1.01 & \\
\hline 2.5 & 15 & .0733 & 1.03 & \\
\hline 3.5 & 15 & .0662 & 1.21 & \\
\hline 2.5 & 19 & .0685 & 1.74 & \\
\hline 3.5 & 19 & .0619 & 1.92 & \\
\hline 2.5 & 21 & .0668 & 1.85 & \\
\hline 3.5 & 21 & .0603 & 2.03 & \\
\hline 5 & 11 & .0672 & .88 & \\
\hline
\end{tabular}


Table 7. Insulation costs and thermal resistances used in the ZIP-Code computer program(cont.)

\begin{tabular}{|c|c|c|c|c|}
\hline \multirow{2}{*}{\multicolumn{2}{|c|}{$\begin{array}{c}\text { Added insulation } \\
\text { R-value (h-ft' }- \text { F/Btu) }\end{array}$}} & \multirow{2}{*}{$\begin{array}{l}\text { Overall component U-value } \\
\qquad\left(\mathrm{Btu} /{ }^{\circ} \mathbf{F} \cdot \mathrm{ft}^{2} \cdot \mathbf{h}\right)\end{array}$} & \multicolumn{2}{|c|}{ Cost $\left(\$ / f t^{2}\right.$ or $\$$ linear $\left.f t\right)$} \\
\hline & & & New construction & Existing \\
\hline Sheathing & Cavity & & & \\
\hline 7 & 11 & .0580 & 1.17 & \\
\hline 5 & 13 & .0642 & .94 & \\
\hline 7 & 13 & .0554 & 1.23 & \\
\hline 5 & 15 & .0618 & 1.14 & \\
\hline 7 & 15 & .0533 & 1.43 & \\
\hline 5 & 19 & .0586 & 1.85 & \\
\hline 7 & 19 & .0505 & 2.14 & \\
\hline 5 & 21 & .0573 & 1.96 & \\
\hline 7 & 21 & .0493 & 2.25 & \\
\hline \multicolumn{5}{|c|}{$\begin{array}{c}\text { Wood-framed OVE (assumed that } 2 \times 6 \text { wall costs the same as a } 2 \times 4 \text { wall) wall - combined insulativ } \\
\text { sheathing and cavity insulation }\left(\$ / \mathrm{ft}^{2}\right)\end{array}$} \\
\hline Sheathing & Cavity & & & \\
\hline 0 & none & 0.2052 & & \\
\hline 2.5 & 19 & .0496 & .91 & \\
\hline 5 & 19 & .0437 & 1.02 & \\
\hline 5 & 21 & .0418 & 1.13 & \\
\hline 7 & 19 & .0399 & 1.31 & \\
\hline 7 & 21 & .0383 & 1.42 & \\
\hline none & 11 & .0840 & .30 & \\
\hline none & 13 & .0777 & .36 & \\
\hline none & 19 & .0577 & .44 & \\
\hline none & 21 & .0550 & .55 & \\
\hline
\end{tabular}

a Fiberglass batts with flame resistant facing and minimal framing for unused basement areas.

b Costs do not include removing and replacing exterior wall material, therefore, only appropriate when exterior sheathing is under renovation. 


\section{Economic Calculations}

The ZIP-Code program is based on a life-cycle cost optimization calculation. A discount rate of $3.4 \%$ is defined for government-sponsored energy related investment evaluations by the Department of Energy. ${ }^{12}$ The effective lifetime of investments in existing houses was set at 20 years and at 30 years for new houses. A present worth factor, used to calculate the current value of future energy savings, is then calculated as shown in Eq. 6 for each region and for each fuel type. This calculation uses energy price escalation factors for 1997-2026 for 4 regions from Ref. 12. These energy price escalation factors are shown in Appendix F. For years beyond 2026, the last factor in the file is repeated.

$$
P W=\sum_{n=1}^{n=\text { ifetime }} \frac{E F_{n} / E F_{\text {baseyear }}}{(1+\text { discount rate })^{n}}
$$

$\begin{array}{lll}\text { where: } & \text { PW } & \text { present worth factor, } \\ \text { EF } & = & \text { price escalation factor (see Appendix F), and } \\ \text { lifetime } & = & \text { effective lifetime of investment, and } \\ \text { discount rate } & = & \text { energy related discount rate, } 0.034 \text { used. }\end{array}$

All energy prices shown in Appendix E reflect those paid by residential consumers in each state in October 1996, consistent with the escalations factors described above. The prices do not include any taxes paid by consumers. Electricity prices were taken from DOE-reported average utility revenues for each state. ${ }^{13}$ These revenues do not represent last $\mathrm{kWh}$ cost for customers with pyramid rate structures or demand charges. Natural gas prices are reported for each state in Ref. 14. Propane prices are reported for each of 7 Petroleum Administration for Defense (PAD) districts in Ref. 15. Distillate oil prices for 24 states, including all of the states located in the Northeast, as well as average prices for each PAD district, are also taken from Ref. 15. The energy content of fuel oil, propane, and natural gas were taken from Ref. 16.

After the changes in annual heating and cooling energy requirements are estimated for an insulation level, the present value of the savings are calculated as shown in Eq. 7. The insulation level producing the greatest savings is then chosen. Examination of this equation shows the importance of the performance assumptions and insulation costs described in this report. The savings are inversely proportional to the HVAC system efficiencies and the assumed duct 
efficiency. The differences in the assumed HVAC efficiency for new and existing houses are responsible for much of the differences in the recommendations for these two groups. The role played by the insulation cost is also significant, as was demonstrated by the effect of omitting the cost of raised heel frames in new construction attics.

$$
\text { SAVINGS }=\left[\frac{\Delta Q_{h}}{n_{h} \times \eta_{\text {duct }}} \times P_{h} \times P W_{h}\right]+\left[\frac{\Delta Q_{c}}{n_{c} \times \eta_{\text {duct }}} \times P_{c} \times P W_{c}\right]-\operatorname{COST}
$$

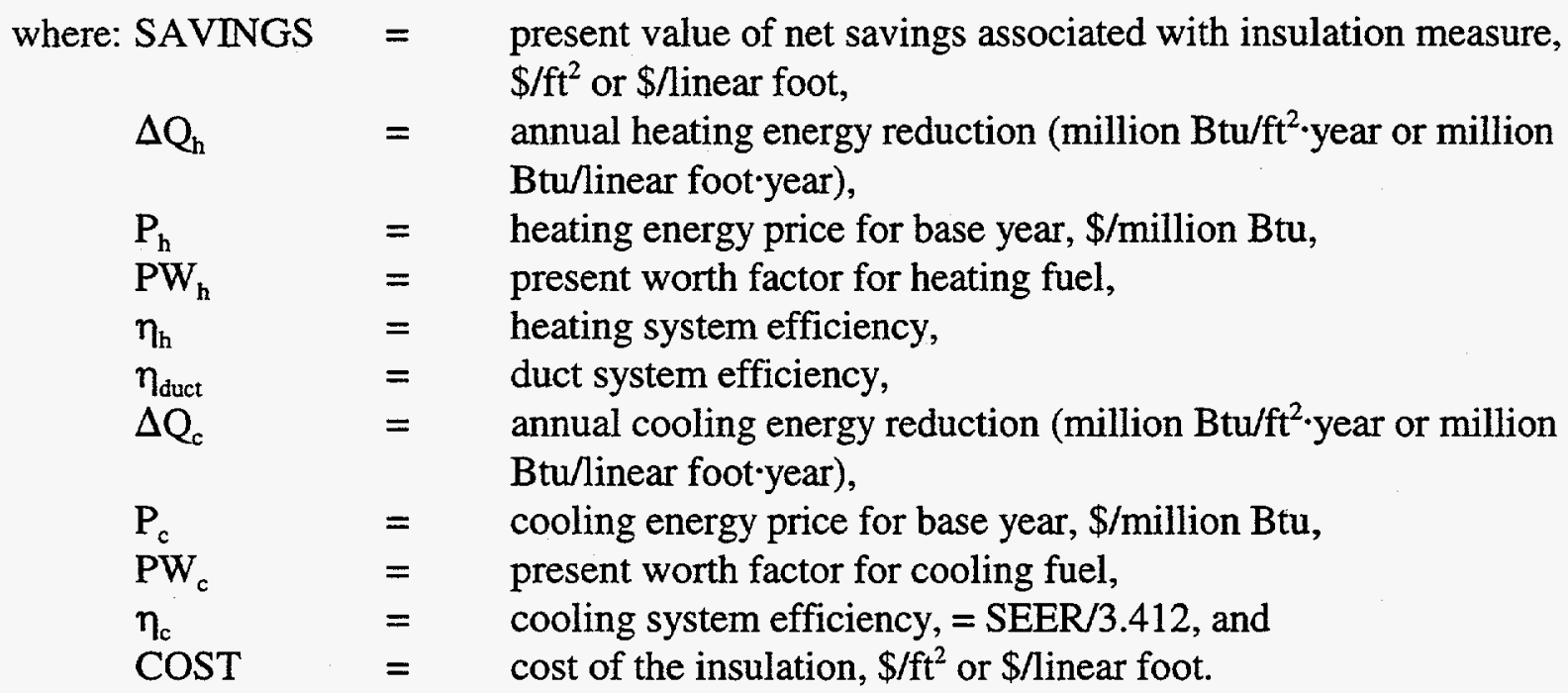

\section{Insulation Groups}

The detailed results of the ZIP-Code cost/benefit analysis will be available to anyone accessing the electronic version of the DOE Insulation Fact Sheet on the Internet. ${ }^{2}$ However, it was necessary to group these recommendations into some more usable format for the printed version. An analysis of the results showed the expected high correlation between the various insulation levels. For example, an area that calls for a higher level of attic insulation is also likely to call for a higher level of floor insulation. Using this trend, six insulation groups were defined for existing houses and seven groups were defined for new houses, as shown in Tables 8 and 9. Each 3-digit zip code area was assigned to one of these groups based on the optimal attic, floor, and cathedral ceiling insulation levels for each type of heating system and for new or existing houses. Presenting this information directly would have required 12 tables (two house 
types times six heating system types). Therefore, the assignment was further simplified for the DOE Insulation Fact Sheet presentation by defining nine insulation zones and assigning the most representative insulation zone to each zip code, as shown in Tables 10 and 11 . When making this assignment, the overall distribution of homes by fuel type, shown in Table 12, was considered. 
Table 8. Recommended insulation levels for existing houses from the 1997 DOE Insulation Fact Sheet(a)

\begin{tabular}{|c|c|c|c|c|c|c|c||}
\hline $\begin{array}{c}\text { Insulation } \\
\text { Group }\end{array}$ & Attic & $\begin{array}{c}\text { Floor over } \\
\text { unconditioned } \\
\text { space }\end{array}$ & $\begin{array}{c}\text { Wall } \\
\text { cavity }\end{array}$ & $\begin{array}{c}\text { Crawl } \\
\text { space } \\
\text { wall(b) }\end{array}$ & $\begin{array}{c}\text { Basement } \\
\text { wall }\end{array}$ & $\begin{array}{c}\text { Add } \\
\text { insulative } \\
\text { sheathing } \\
\text { to an } \\
\text { uninsulated } \\
\text { wall(c) }\end{array}$ & $\begin{array}{c}\text { Add } \\
\text { insulative } \\
\text { sheathing } \\
\text { to an } \\
\text { insulated } \\
\text { wall(c) }\end{array}$ \\
\hline E1 & 19 & 11 & 0 & 11 & 11 & 5 & 0 \\
\hline E2 & 30 & 11 & 11 & 11 & 11 & 5 & 0 \\
\hline E3 & 38 & 11 & 11 & 19 & 11 & 5 & 0 \\
\hline E4 & 38 & 19 & 11 & 19 & 11 & 5 & 0 \\
\hline E5 & 38 & 25 & 11 & 19 & 11 & 5 & 5 \\
\hline E6 & 49 & 25 & 11 & 25 & $11-13$ & 5 & 5 \\
\hline
\end{tabular}

(a) R-values have units of ${ }^{\circ} \mathrm{F} \cdot \mathrm{ft}^{2} \cdot \mathrm{h} / \mathrm{Btu}$. This table, when used with Tables 10 and 11 , provides recommended total R-values for existing houses and was produced using the ZIP-Code computer program. The recommendations are based on an analysis of cost-effectiveness, using average local energy prices, regional average insulation costs, equipment efficiencies, climate factors, and energy savings for both the heating and cooling seasons.

(b) Use only if floor is uninsulated and the crawlspace is unventilated - see the discussion about unventilated crawlspaces.

(c) Recommendation assumes that the exterior siding was removed for other purposes, i.e., does not include any consideration of the cost of removing and replacing the exterior siding. The R-values shown here represent 1 inch of foam sheathing. Foam sheathing with R-values up to R-7 could be used. 
Table 9. Recommended insulation levels for residential new construction from the 1997 DOE Insulation Fact Sheet (a)

\begin{tabular}{|c|c|c|c|c|c|c|c|}
\hline \multicolumn{8}{|c|}{ Attics and Floors } \\
\hline \multirow{2}{*}{$\begin{array}{l}\text { Insulation } \\
\text { Group }\end{array}$} & \multirow[t]{2}{*}{ Attic(b) } & \multirow[t]{2}{*}{ Floors } & \multirow{2}{*}{$\begin{array}{l}\text { Cathedral } \\
\text { ceilings }(c)\end{array}$} & & & \multicolumn{2}{|c|}{ Metal-framed building(d) } \\
\hline & & & & & & Attic(b) & Floors \\
\hline N1 & 22 & 11 & 22 & & & 30 & 11 \\
\hline N2 & 38 & 11 & 30 & & & 30 & 25 \\
\hline N3 & 38 & 13 & 38 & & & 49 & 25 \\
\hline N4 & 38 & 25 & 38 & & & 49 & 25 \\
\hline N5 & 49 & 25 & 38 & & & 49 & 25 \\
\hline N6 & 49 & 25 & 38 & & & 49 & 25 \\
\hline N7 & 49 & 25 & 60 & & & 49 & 25 \\
\hline \multicolumn{8}{|c|}{ Walls } \\
\hline \multirow[t]{2}{*}{$\begin{array}{l}\text { Insulation } \\
\text { Group }\end{array}$} & \multicolumn{2}{|c|}{ Wood frame wall assembly $(c, e)$} & \multirow{2}{*}{$\begin{array}{l}\text { Optimum-Value } \\
\text { Engineered } \\
\text { (OVE) wall } \\
\text { cavities(f) }\end{array}$} & \multirow{2}{*}{$\begin{array}{l}\text { Above-grade } \\
\text { masonry wall } \\
\text { interior }(g)\end{array}$} & \multirow[t]{2}{*}{ Band joist } & \multicolumn{2}{|c|}{$\begin{array}{l}\text { Metal frame wall } \\
\text { assembly }(c, d, e)\end{array}$} \\
\hline & Insulative Sheathing & Cavity & & & & Insulative Sheathing & Cavity \\
\hline N1 & 0 & 11 to 13 & 19 & 5.7 & 19 & 2.5 to 5 & 11 to 13 \\
\hline N2 & 0 & 11 to 13 & 19 & 9.5 & 19 & 2.5 to 5 & 11 to 13 \\
\hline N3 & 0 & 11 to 15 & 19 & 11.4 & 30 & 2.5 to 5 & 11 to 13 \\
\hline N4 & 0 to 5 & 11 to 15 & 19 & 11.4 & 30 & 2.5 to 7 & 11 to 15 \\
\hline N5 & 0 to 7 & 11 to 15 & 19 & 11.4 & 30 & 5 to 7 & 11 to 15 \\
\hline N6 & 2.5 to 7 & 13 to 21 & 21 & 15 & 30 & 5 to 7 & 11 to 21 \\
\hline N7 & 5 to 7 & 19 to 21 & 21 & 15 & 30 & 5 to 7 & 13 to 21 \\
\hline \multicolumn{8}{|c|}{ Basements and Foundations } \\
\hline $\begin{array}{l}\text { Insulation } \\
\text { Group }\end{array}$ & $\begin{array}{c}\text { Crawl space } \\
\text { walls(h) }\end{array}$ & Slab edge & $\begin{array}{c}\text { Basement wall } \\
\text { exterior } \\
\text { (below grade) }\end{array}$ & $\begin{array}{c}\text { Basement wall } \\
\text { interior (below } \\
\text { grade) }(\mathrm{g})\end{array}$ & & & \\
\hline N1 & 11 & 0 & 4 & 11 & & & \\
\hline N2 & 13 & 4 & 4 & 11 & & & \\
\hline N3 & 19 & 4 & 4 & 11 & & & \\
\hline N4 & 19 & 4 & 5 & 11 & & & \\
\hline N5 & 19 & 8 & 10 & 11 & & & \\
\hline N6 & 19 & 8 & 15 & 19 & & & \\
\hline N7 & 19 & 8 & 15 & 19 & & & \\
\hline
\end{tabular}

(a) R-values have units of ${ }^{\circ} \mathrm{F} \cdot \mathrm{ft}^{2} \cdot \mathrm{h} / \mathrm{Btu}$. This table, when used with Tables 10 and 11 provides recommended R-values for new houses and was produced using the ZIP-Code computer program. The recommendations are based on an analysis of cost-effectiveness, using average local energy prices, regional average insulation costs, equipment efficiencies, climate factors, and energy savings for both the heating and cooling seasons.

(b) Does not include the cost of raised heel framing necessary to install the higher levels of insulation in the portions of the attic near the eaves.

(c) includes the cost of thicker framing where necessary.

(d) The recommended insulation levels for metal frames will not necessarily give you performance as good as the recommended levels for a woodframed building. Please see the discussion about heat loss paths associated with metal frames.

(e) For new construction, it is important to use both the insulative sheathing and cavity insulation recommended, especially for metal walls. Assumes insulative sheathing placed outside of wood sheathing product. For a full discussion of the ranges shown here, see new homes discussion.

(f) These recommendations assume that a $2 \times 6$ wall can be built for the same cost as a $2 \times 4$ wall, using a careful design procedure called Optimum Value Engineering. Discuss this option with your builder.

(g) Evaluation included cost of necessary framing but did not include cost of finishing drywall and paint.

(h) Crawl space walls are only insulated if the crawl space is unventilated. Please see the Builders Foundation Handbook listed at the back of the fact sheet. 
Table 10. Zip Codes and corresponding Insulation Zones from the 1997 DOE Insulation Fact Sheet

\begin{tabular}{|c|c|c|c|c|c|c|c|c|c|c|c|c|c|}
\hline \multirow{4}{*}{$\begin{array}{l}\text { If Your Zip } \\
\text { code Begins } \\
\text { With These } \\
\text { Three Numbers }\end{array}$} & & 1239 & 1938 & 2607 & 3283 & 4045 & 4775 & 5498 & 6256 & 7063 & 7804 & 8554 & 9403 \\
\hline & & 1249 & 1948 & 2617 & 3293 & 4055 & 4785 & 5508 & 6266 & 7073 & 7813 & 8564 & 9413 \\
\hline & Insulation & 1259 & 1958 & 2627 & 3303 & 4065 & 4798 & $\begin{array}{lll}551 & 8\end{array}$ & 6276 & 7083 & 7823 & 8574 & 9424 \\
\hline & Zone Is: & 1269 & 1968 & 2637 & 3313 & 4075 & 4806 & 5538 & 6286 & 7104 & 7833 & 8598 & 943 \\
\hline \multirow{2}{*}{010} & \multirow{2}{*}{6} & 1279 & 1977 & 2647 & 3323 & 4085 & 4816 & 5548 & 6296 & 7114 & 7843 & 8609 & 944 \\
\hline & & 1289 & 1987 & 2657 & 3333 & 4095 & 4826 & 5568 & 6307 & 7124 & 7853 & 8638 & 945 \\
\hline \multirow{2}{*}{011} & 6 & 1299 & 1997 & 2667 & 3343 & 4107 & 4836 & 5578 & 6317 & 7134 & 7864 & 8645 & 946 \\
\hline & & 1309 & & 2677 & 3353 & 4115 & 4848 & 5588 & 6337 & 7144 & 787.4 & 8659 & 947 \\
\hline 012 & 8 & 1319 & 200 & 2687 & 3363 & 4125 & 4858 & 5598 & 6347 & 7164 & 7883 & 8706 & 948 \\
\hline \multirow{2}{*}{013} & 8 & 1329 & 2007 & 2707 & 3373 & 4137 & 4868 & 5608 & 6357 & 7174 & 7893 & 8716 & 9492 \\
\hline & 0 & 1339 & 2017 & 2717 & 3383 & 4147 & 4878 & 5618 & 6367 & 7185 & 7905 & 8726 & 950 \\
\hline \multirow{2}{*}{014} & 8 & 1349 & 2027 & 2728 & 3393 & 4155 & 4888 & 5628 & 6375 & 7194 & 7915 & 8736 & 951 \\
\hline & & 1359 & 2037 & 2738 & 3423 & 4165 & 4898 & 5638 & 6385 & 7205 & 7925 & 8746 & 952 \\
\hline 015 & 8 & 1369 & 2047 & 2748 & 3443 & 4175 & 4906 & 5648 & 6395 & 7215 & 7935 & 8758 & 953 \\
\hline 016 & 8 & 1379 & 2057 & 2757 & 3463 & 4185 & 4916 & 5658 & 6407 & 7225 & 7945 & 8776 & 954 \\
\hline & & 1389 & 2068 & 2767 & 3473 & 4205 & 4926 & 5668 & 6417 & 7235 & 7954 & 8786 & 9556 \\
\hline 017 & 8 & 1399 & 2078 & 2777 & 3493 & 4215 & 4938 & 5678 & 6447 & 7245 & 7964 & 8794 & 956 \\
\hline & & 1409 & 2088 & 2787 & 3505 & 4225 & 4948 & 5709 & 6457 & 7255 & 7974 & 8803 & 957 \\
\hline 018 & 8 & 1419 & 2098 & 2797 & 3515 & 4235 & 4958 & 5719 & 6467 & 7265 & 7984 & 8816 & 9583 \\
\hline 010 & & 1429 & 2108 & 2807 & 3525 & 4245 & 4968 & 5729 & 6477 & 7277 & 7994 & 8823 & 9593 \\
\hline 019 & 0 & 1439 & 2118 & 2817 & 3545 & 4255 & 4978 & 5739 & 6485 & 7285 & & 8836 & 9603 \\
\hline & & 1449 & 2128 & 2827 & 3557 & 4265 & 4988 & 5749 & 6507 & 7295 & 800 & 8844 & 9616 \\
\hline 0206 & 0689 & 1459 & 2138 & 2837 & 3567 & 4275 & 4998 & 5759 & 6517 & 7305 & 8006 & 8907 & 9672 \\
\hline 0216 & 0699 & 1469 & 2148 & 2845 & 3577 & 4308 & & 5769 & 6527 & 7315 & 8016 & 8914 & 9683 \\
\hline 0226 & 0706 & 1479 & 2159 & 2857 & 3587 & 4318 & 500 & 5779 & 6537 & 7344 & 8026 & 8939 & 9705 \\
\hline 0236 & 0716 & 1489 & 2168 & 2868 & 3597 & 4328 & 5009 & 5809 & 6547 & 7355 & 8036 & 8948 & 9715 \\
\hline 0246 & 0726 & 1499 & 2179 & 2879 & 3605 & 4338 & 5019 & 5819 & 6557 & 7365 & 8049 & 8958 & 9725 \\
\hline 0258 & 0736 & 1508 & 2187 & 2889 & 3615 & 4348 & 5029 & 5829 & 6567 & 7377 & 8056 & 8968 & 9735 \\
\hline 0266 & 0746 & 1518 & 2199 & 2899 & 3625 & 4358 & 5039 & 5839 & 6577 & 7388 & 8066 & 8977 & 9745 \\
\hline 0276 & 0756 & 1528 & 2208 & 2905 & 3634 & 4368 & 5049 & 5849 & 6587 & 7397 & 8076 & 8989 & 9755 \\
\hline 0288 & 0766 & 1538 & 2218 & 2915 & 3644 & 4378 & 5059 & 5859 & 6607 & 7405 & 8086 & & 9767 \\
\hline 0298 & 0776 & 1548 & 2228 & 2925 & 3654 & 4388 & 5069 & 5869 & 6617 & 7415 & 8096 & 800 & 9777 \\
\hline 0309 & 0788 & 1558 & 2238 & 2935 & 3664 & 4398 & 5079 & 5879 & 6627 & 7437 & 8106 & 9001 & 9785 \\
\hline 0319 & 0798 & 1569 & 2248 & 2944 & 3674 & 4408 & 5089 & 5889 & 6647 & 7445 & 8118 & 9011 & 9795 \\
\hline 0329 & 0806 & 1578 & 2258 & 2955 & 3685 & 4418 & 5109 & 5908 & 6657 & 7455 & 8129 & 9021 & 9805 \\
\hline 0339 & 0816 & 1589 & 2269 & 2965 & 3695 & 4428 & 5119 & 5918 & 6667 & 7468 & 8136 & 9031 & 9815 \\
\hline 0349 & 0826 & 1598 & 2278 & 2975 & 3705 & 4438 & 5129 & 5928 & 6675 & 7475 & 8146 & 9041 & 9825 \\
\hline 0359 & 0836 & 1608 & 2289 & 2984 & 3715 & 4448 & 5139 & 5938 & 6687 & 7485 & 8156 & 9051 & 9835 \\
\hline 0369 & 0846 & 1618 & 2298 & 2994 & 3725 & 4458 & 5149 & 5948 & 6698 & 7495 & 8166 & 9063 & 9845 \\
\hline 0379 & 0856 & 1629 & 2308 & & 3735 & 4468 & 5158 & 5958 & 6705 & 7504 & 8209 & 9071 & 9855 \\
\hline 0389 & 0866 & 1638 & 2318 & 30 & 3745 & 4478 & 5168 & 5968 & 6715 & 7514 & 8219 & 9081 & 9865 \\
\hline 0399 & 0876 & 1649 & 2328 & 3005 & 3765 & 4488 & 5209 & 5978 & 6725 & 7524 & 8228 & 9102 & 9885 \\
\hline 0409 & 0886 & 1659 & 2337 & 3015 & 3775 & 4498 & 5219 & 5988 & 6735 & 7534 & 8239 & 9112 & 9895 \\
\hline 0419 & 0896 & 1669 & 2347 & 3025 & 3785 & 4505 & 5229 & 5998 & 6747 & 7544 & 8249 & 9122 & 9907 \\
\hline 0429 & & 1679 & 2357 & 3035 & 3795 & 4515 & 5239 & & 6755 & 7554 & 8259 & 9132 & 9917 \\
\hline 0439 & 100 & 1688 & 2367 & 3044 & 3805 & 4525 & 5249 & 600 & 6768 & 7564 & 8269 & 9142 & 9927 \\
\hline 0449 & 1008 & 1699 & 2377 & 3055 & 3815 & 4538 & 5258 & 6008 & 6778 & 7574 & 8279 & 9152 & 9935 \\
\hline 0459 & 1018 & 1708 & 2387 & 3065 & 3825 & 4548 & 5268 & 6018 & 6787 & 7584 & 8289 & 9162 & 9945 \\
\hline 0469 & 1028 & 1718 & 2397 & 3075 & 3835 & 4558 & 5278 & 6026 & 6795 & 7593 & 8299 & 9173 & 9956 \\
\hline 0479 & 1038 & 1728 & 2408 & 3085 & 3845 & 4565 & 5288 & 6036 & 6807 & 7604 & 8309 & 9182 & 9966 \\
\hline 0489 & 1048 & 1738 & 2418 & 3095 & 3857 & 4577 & 5308 & 6046 & 6817 & 7614 & 8319 & 9191 & 9976 \\
\hline 0499 & 1058 & 1748 & 2427 & 3104 & 3865 & 4588 & 5318 & 6056 & 6837 & 7624 & 8327 & 9201 & 9986 \\
\hline 0509 & 1068 & 1758 & 2439 & 3114 & 3874 & 4607 & 5328 & 6066 & 6847 & 7634 & 8335 & 9211 & 9992 \\
\hline 0519 & 1078 & 1768 & 2449 & 3124 & 3884 & 4617 & 5338 & 6076 & 6857 & 7644 & 8348 & 9224 & \\
\hline 0529 & 1088 & 1778 & 2458 & 3134 & 3894 & 4627 & 5348 & 6096 & 6867 & 7654 & 8355 & 9233 & \\
\hline 0539 & 1099 & 1788 & 2469 & 3144 & 3904 & 4638 & 5358 & 6108 & 6879 & 7664 & 8365 & 9243 & \\
\hline 0549 & 1108 & 1798 & 2477 & 3154 & 3914 & 4648 & 5368 & 6118 & 6887 & 7674 & 8375 & 9253 & \\
\hline 0569 & 1118 & 1808 & 2487 & 3163 & 3924 & 4658 & 5378 & 6126 & 6897 & 7684 & 8385 & 9261 & \\
\hline 0579 & 1128 & 1818 & 2497 & 3174 & 3934 & 4668 & 5388 & 6136 & 6907 & 7694 & 8406 & 9271 & \\
\hline 0589 & 1138 & 1829 & 2507 & 3184 & 3943 & 4678 & 5398 & 6146 & 6919 & 7703 & 8416 & 9281 & \\
\hline 0599 & 1148 & 1838 & 2517 & 3194 & 3953 & 4688 & 5408 & 6156 & 6929 & 7713 & 8436 & 9301 & \\
\hline 0609 & 1158 & 1848 & 2527 & 3204 & 3963 & 4698 & 5418 & 6166 & 6939 & 7723 & 8446 & 9312 & \\
\hline 0619 & 1168 & 1858 & 2537 & 3214 & 3974 & 4705 & 5428 & 6176 & & 7733 & 8456 & 9323 & \\
\hline 0629 & 1178 & 1868 & 2547 & 3224 & & 4715 & 5438 & 6186 & 700 & 7743 & 8466 & 9333 & \\
\hline 0639 & 1188 & 1878 & 2557 & 3235 & 400 & 4725 & 5448 & 6196 & 7003 & 7753 & 8476 & 9342 & \\
\hline 0649 & 1198 & 1889 & 2567 & 3244 & 4005 & 4738 & 5459 & 6206 & 7013 & 7763 & 8504 & 9353 & \\
\hline 0659 & 1209 & 1898 & 2577 & 3254 & 4015 & 4745 & 5468 & 6226 & 7033 & 7773 & 8514 & 9363 & \\
\hline 0668 & 1219 & 1908 & 2587 & 3263 & 4025 & 4755 & 5478 & 6236 & 7043 & 7783 & 8524 & 9373 & \\
\hline 0679 & 1229 & 1918 & 2597 & 3273 & 4035 & 4765 & 5489 & 6246 & 7053 & 7793 & 8534 & 9393 & \\
\hline
\end{tabular}

"For Hawaii, Puerto Rico, and Virgin Islands, your Insulation Zone is 1. 
Table 11. Insulation group assignment for each Insulation Zone from the 1997 DOE Insulation

Fact Sheet (a)

\begin{tabular}{|c|c|c|c|c|c|c|c|c|c|c|c|c|}
\hline \multirow{2}{*}{$\begin{array}{l}\text { Insulation } \\
\text { Zone }\end{array}$} & \multicolumn{6}{|c|}{ Existing Houses } & \multicolumn{6}{|c|}{ New Houses } \\
\hline & $\begin{array}{l}\text { Gas } \\
\text { heat }\end{array}$ & $\begin{array}{l}\text { Electric } \\
\text { furnace }\end{array}$ & $\begin{array}{c}\text { Electric } \\
\text { baseboard } \\
\text { (b) }\end{array}$ & $\begin{array}{l}\text { Heat } \\
\text { Pump }\end{array}$ & LPG & $\begin{array}{c}\text { Fuel } \\
\text { Oil }\end{array}$ & $\begin{array}{l}\text { Gas } \\
\text { heat }\end{array}$ & $\begin{array}{l}\text { Electric } \\
\text { furnace }\end{array}$ & $\begin{array}{l}\text { Electric } \\
\text { baseboard } \\
\text { (b) }\end{array}$ & $\begin{array}{l}\text { Heat } \\
\text { Pump }\end{array}$ & LPG & $\begin{array}{c}\text { Fuel } \\
\text { Oil }\end{array}$ \\
\hline 1 & E1 & $\mathrm{E} 4$ & E3 & E3 & $\mathrm{E} 2$ & $\mathrm{E} 2$ & N1 & N5 & N4 & $\mathrm{N} 2$ & $\mathrm{~N} 2$ & N2 \\
\hline 2 & E2 & E4 & E4 & E3 & E2 & $\mathrm{E} 3$ & $\mathrm{~N} 2$ & N5 & N5 & N3 & N4 & N3 \\
\hline 3 & E3 & E4 & E3 & E3 & $\mathrm{E} 2$ & E3 & N3 & N5 & N5 & N3 & N5 & N3 \\
\hline 4 & E3 & E6 & $\mathrm{E} 4$ & E3 & $\mathrm{E} 4$ & E3 & N5 & N5 & N5 & N5 & N5 & N5 \\
\hline 5 & E4 & E6 & E5 & E4 & E6 & E5 & N5 & N5 & N5 & N5 & N5 & N5 \\
\hline 6 & $\mathrm{E} 4$ & E6 & E6 & E6 & E6 & E5 & N5 & N6 & N5 & N5 & N5 & N5 \\
\hline 7 & E5 & E6 & E6 & E5 & E6 & E5 & N5 & N5 & N5 & N5 & N5 & N5 \\
\hline 8 & E5 & E6 & E6 & E6 & E6 & E5 & N5 & N6 & N5 & N5 & N5 & N5 \\
\hline 9 & E6 & E6 & E6 & E6 & E6 & E6 & N5 & N7 & N6 & N5 & N5 & N5 \\
\hline
\end{tabular}

(a)Electric air conditioning is assumed for all homes.

(b)Use for any electric resistance heating system without ducts, and for a central electric furnace if the ducts are totally within the conditioned part of the house.

Table 12. Distribution (\%) of heating system fuels for new construction and existing houses (from Ref. 17)

\begin{tabular}{|l|c|c|}
\hline Heating system & $\begin{array}{c}\text { Built 1991-1993 (new } \\
\text { construction) }\end{array}$ & All homes (existing) \\
\hline Natural gas & 46 & 53 \\
\hline Electric resistance furnace & 19 & 10 \\
\hline Electric heat pump & 19 & 8 \\
\hline Electric (ductless) & 0 & 9 \\
\hline LPG (propane) & 8 & 5 \\
\hline Fuel oil & 3 & 11 \\
\hline
\end{tabular}




\section{Discussion}

As shown in Appendix C, U-values for framed walls were carefully evaluated. Wood frame walls were evaluated using a parallel-path heat transfer model which evaluated sheathing and cavity insulation together as a system. Metal-frame walls were evaluated using the modified zone heat transfer model with a minimum insulative sheathing requirement of $1 / 2 \mathrm{inch}$. This combination of insulative sheathing and cavity insulation is more complex than the other insulation applications considered and was therefore examined more closely. For other insulation measures, an optimal insulation level is calculated and reported. For the walls however, several combinations of insulative sheathing and cavity insulation are possible. Appendix $G$ shows the net savings for each possible wall treatment (calculated using Eq. 7) for each insulation group. To generate these summaries, the ZIP-Code computer program was run for each zipcode/heating system combination. After examining these results, a range of wall insulation options was selected, as shown in Table 9. The effective wall R-values for these combinations are shown in Table 13.

Walls were evaluated differently for existing houses. Three options were considered: (1) blowing insulation into an empty wall cavity, (2) placing insulative sheathing over a wall without any cavity insulation, and (3) placing insulative sheathing over a wall with pre-existing cavity insulation. The second and third options are only applicable when existing siding is being replaced for some other reason, i.e, the costs of removing and replacing existing exterior siding were not considered.

It is interesting to compare the 1997 Fact Sheet's recommendations to those presented in the 1988 Fact Sheet, the Model Energy Code, and ASHRAE Standard 90.2.,18,4 Figures 1 and 2 and Tables 14 and 15 facilitate this comparison. One of the most important changes between the previous edition of the Fact Sheet and this latest revision is the separation of recommendations for new and existing houses. Two factors, heating/cooling system efficiencies and economic lifetimes, are most responsible for the differences between the recommendations for these two groups. There are also differences in the installed cost of insulation measures in new and existing houses, most especially for wall insulation. The maps also reflect differences caused by 
Table 13. Total effective $\mathrm{R}$-values for the recommended wall insulation combinations, including surface heat transfer coefficients, exterior siding, $1 / 2$ in. wood sheathing, joists, and drywall

\begin{tabular}{|c|c|c|c|c|c|c|c|c|}
\hline \multirow[t]{2}{*}{$\begin{array}{c}\text { Insulation } \\
\text { Group }\end{array}$} & \multicolumn{2}{|c|}{$\begin{array}{l}\text { Minimum recommended } \\
\text { R-value }\end{array}$} & \multicolumn{2}{|c|}{$\begin{array}{l}\text { Maximum recommended } \\
\text { R-value }\end{array}$} & \multicolumn{2}{|c|}{ Total U-value } & \multicolumn{2}{|c|}{$\begin{array}{c}\text { Effective wall } \\
\text { R-value }\end{array}$} \\
\hline & $\begin{array}{l}\text { Insulative } \\
\text { Sheathing }\end{array}$ & Cavity & $\begin{array}{l}\text { Insulative } \\
\text { Sheathing }\end{array}$ & Cavity & Minimum & Maximum & Minimum & Maximum \\
\hline \multicolumn{9}{|c|}{ Wood-frame wall assemblv (without insulation, $U$-value $=.2052$, effective $R$-value $=4.9$ ) } \\
\hline N1 & 0 & 11 & 0 & 13 & .084 & .078 & 11.9 & 12.9 \\
\hline $\mathrm{N} 2$ & 0 & 11 & 0 & 13 & .084 & .078 & 11.9 & 12.9 \\
\hline N3 & 0 & 11 & 0 & 15 & .084 & .073 & 11.9 & 13.8 \\
\hline N4 & 0 & 11 & 5 & 15 & .084 & .052 & 11.9 & 19.4 \\
\hline N5 & 0 & 11 & 7 & 15 & .084 & .046 & 11.9 & 21.6 \\
\hline N6 & 2.5 & 13 & 7 & 21 & .064 & .038 & 15.6 & 26.1 \\
\hline N7 & 5 & 19 & 7 & 21 & .044 & .038 & 22.7 & 26.1 \\
\hline \multicolumn{9}{|c|}{ Metal frame wall assembly (without insulation, $U$-value $=.2362$, effective $R$-value $=4.2$ ) } \\
\hline N1 & 2.5 & 11 & 5 & 13 & .081 & .064 & 12.4 & 15.6 \\
\hline $\mathrm{N} 2$ & 2.5 & 11 & 5 & 13 & .081 & .064 & 12.4 & 15.6 \\
\hline N3 & 2.5 & 11 & 5 & 13 & .081 & .064 & 12.4 & 15.6 \\
\hline N4 & 2.5 & 11 & 7 & 15 & .081 & .053 & 12.4 & 18.8 \\
\hline N5 & 5 & 11 & 7 & 15 & .067 & .053 & 14.9 & 18.8 \\
\hline N6 & 5 & 11 & 7 & 21 & .067 & .049 & 14.9 & 20.4 \\
\hline N7 & 5 & 13 & 7 & 21 & .064 & .049 & 15.6 & 20.4 \\
\hline
\end{tabular}

using energy costs for each state rather than average costs for four regions, and adjusting the insulation cost for each state as well. The revision also provides a separate consideration of heat pump systems, because their fuel cost and efficiency are markedly different from oil- and gasfired furnaces. Neither the Model Energy Code (MEC) nor ASHRAE Standard 90.2 offer separate recommendations for different heating system types. The DOE Insulation Fact Sheet therefore agrees with these two documents to varying degrees, depending on the selected fuel and local fuel costs. 


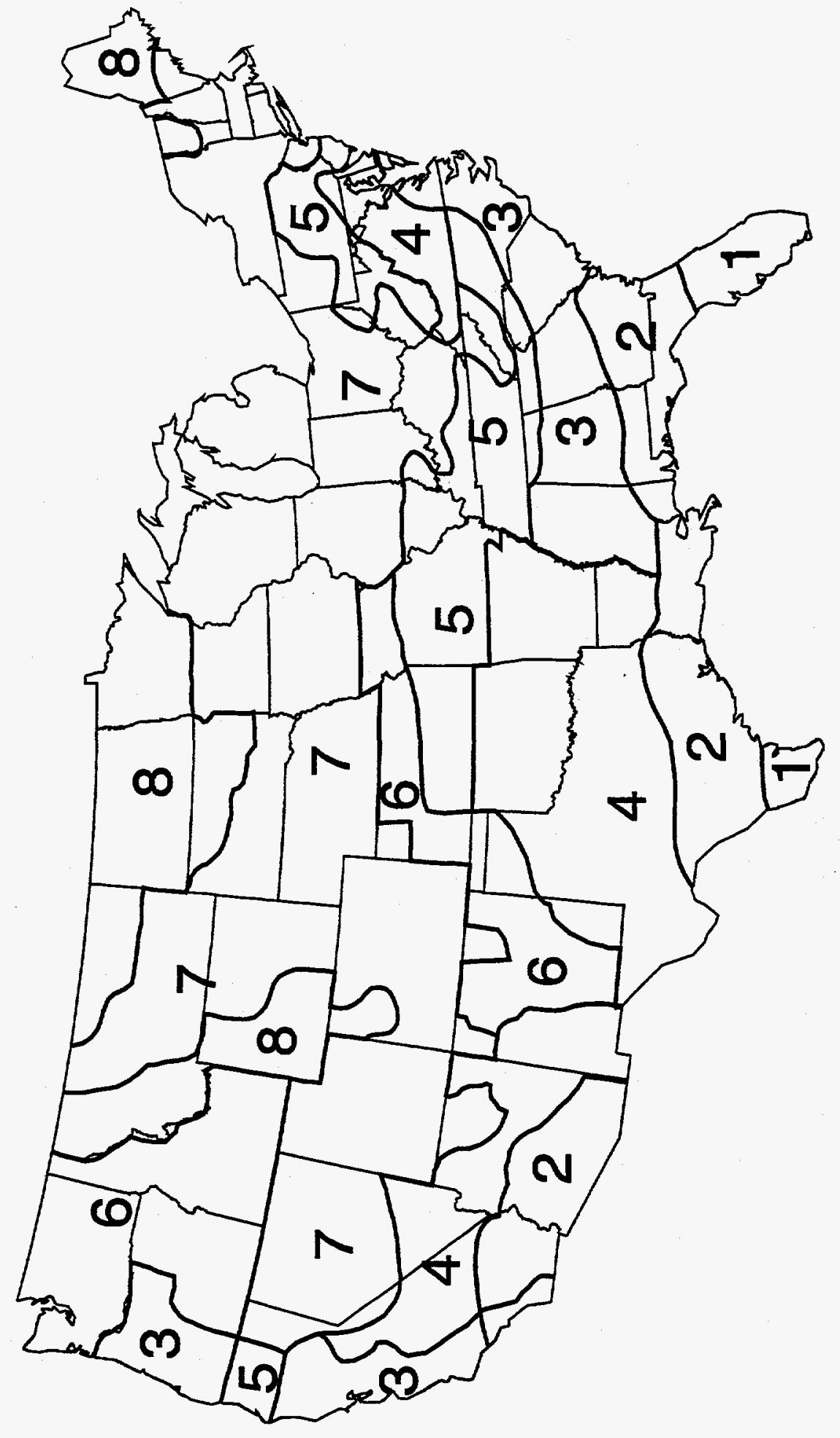

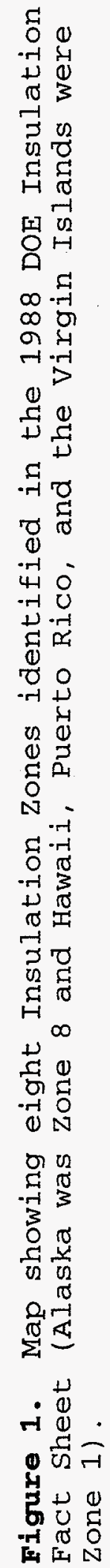







Table 14. Comparison of recommended attic insulation R-values from the MEC, ASHRAE90.2, and the DOE Insulation Fact Sheet

\begin{tabular}{|c|c|c|c|c|c|c|c|}
\hline \multirow[t]{2}{*}{ City } & \multirow{2}{*}{$\begin{array}{c}\text { MEC } \\
\text { (1992) } \\
\text { (all } \\
\text { fuels) }\end{array}$} & \multirow{2}{*}{$\begin{array}{c}\text { ASHRAE } \\
90.2 \\
(1993)^{\mathrm{a}} \\
\text { (all fuels) }\end{array}$} & \multirow{2}{*}{$\begin{array}{c}1988 \text { Fact } \\
\text { Sheet } \\
\text { (heat pump } \\
\text { or gas) }\end{array}$} & \multicolumn{2}{|c|}{$\begin{array}{c}1997 \text { Fact Sheet }^{\mathrm{a}} \\
\text { (gas heat) }\end{array}$} & \multicolumn{2}{|c|}{$\begin{array}{c}1997 \text { Fact Sheet }^{\mathrm{a}} \\
\text { (heat pump) }\end{array}$} \\
\hline & & & & Existing & $\begin{array}{c}\text { New } \\
\text { construction }\end{array}$ & Existing & $\begin{array}{c}\text { New } \\
\text { construction }\end{array}$ \\
\hline St. Paul & 38 & 49 & 38 & 38 & 49 & 49 & 49 \\
\hline Salt Lake City & 38 & 30 & 38 & 38 & 49 & 49 & 49 \\
\hline Seattle & 32 & 30 & 38 & 38 & 49 & 38 & 49 \\
\hline St. Louis & 32 & 30 & 38 & 38 & 49 & 38 & 49 \\
\hline Washington, D.C. & 32 & 30 & 30 & 38 & 49 & 38 & 49 \\
\hline San Francisco & 25 & 30 & 30 & 38 & 38 & 38 & 38 \\
\hline Houston & 23 & 30 & 30 & 38 & 38 & 38 & 38 \\
\hline Miami & 20 & 30 & 19 & 38 & 38 & 38 & 38 \\
\hline
\end{tabular}

a - assumes ducts outside conditioned space

Some recommendations in the DOE Fact Sheet differ from those found in ASHRAE 90.2, or from the Builder's Foundation Handbook. ${ }^{4,19}$ The differences between these recommendations can largely be attributed to two factors. First, the fuel price escalation forecasts used in this most recent analysis are much lower than those used five to nine years ago. Using an average fuel price escalation rate of $5 \%$ and a mortgage rate of $11 \%$, as was done for the Builder's Foundation Handbook in 1991, produces a present worth ratio (defined in Ref. 19) of 18.16. Using an average fuel price escalation rate of $1 \%$, more appropriate for 1997 , produces a present worth ratio of 11.91 (see Table 5.7 in Ref. 19). In other words, the projected value of the energy saved with the present set of economic factors is about $35 \%$ less than with the economic factors used in 1991. However, a second factor serves to counteract this effect. A discount rate is used to define the present value of future savings, as was shown in Eq. 6 (and was included in Ref. 19 via the selected mortgage rate). Earlier analyses, including the $1988 \mathrm{DOE}$ Insulation fact sheet and early versions of the MEC, were based on a 7\% discount rate. A lower discount rate, $3.4 \%$, 
Table 15. Recommended insulation levels from the 1988 DOE Insulation Fact Sheet (Insulation Zones shown in this table refer to Fig. 1.)

"Recommended Total R-Values for Existing Houses in Eight Insulation Zones"a"

\begin{tabular}{|c|c|c|c|c|c|c|c|c|}
\hline \multirow{2}{*}{$\begin{array}{c}\text { Component } \\
\begin{array}{c}\text { Insulation } \\
\text { Zone }\end{array}\end{array}$} & \multicolumn{2}{|c|}{$\begin{array}{l}\text { Ceilings Below } \\
\text { Ventilated Attics }\end{array}$} & \multicolumn{2}{|c|}{$\begin{array}{l}\text { Floors over Unheated } \\
\text { Crawlspaces, Basements }\end{array}$} & \multicolumn{2}{|c|}{$\begin{array}{c}\text { Exterior Walls }{ }^{\mathbf{b}} \text { (Wood } \\
\text { Frame) }\end{array}$} & \multicolumn{2}{|c|}{ Crawlspace Walls ${ }^{\mathrm{c}}$} \\
\hline & $\begin{array}{l}\text { Oil, Gas, } \\
\text { Heat Pump }\end{array}$ & $\begin{array}{c}\text { Electric } \\
\text { Resistance }\end{array}$ & $\begin{array}{l}\text { Oil, Gas, } \\
\text { Heat Pump }\end{array}$ & $\begin{array}{c}\text { Electric } \\
\text { Resistance }\end{array}$ & $\begin{array}{l}\text { Oil, Gas, } \\
\text { Heat Pump }\end{array}$ & $\begin{array}{c}\text { Electric } \\
\text { Resistance }\end{array}$ & $\begin{array}{l}\text { Oil, Gas, } \\
\text { Heat Pump }\end{array}$ & $\begin{array}{c}\text { Electric } \\
\text { Resistance }\end{array}$ \\
\hline 1 & 19 & 30 & 0 & 0 & 0 & 11 & 11 & 11 \\
\hline 2 & 30 & 30 & 0 & 0 & 11 & 11 & 19 & 19 \\
\hline 3 & 30 & 38 & 0 & 19 & 11 & 11 & 19 & 19 \\
\hline 4 & 30 & 38 & 19 & 19 & 11 & 11 & 19 & 19 \\
\hline 5 & 38 & 38 & 19 & 19 & 11 & 11 & 19 & 19 \\
\hline 6 & 38 & 38 & 19 & 19 & 11 & 11 & 19 & 19 \\
\hline 7 & 38 & 49 & 19 & 19 & 11 & 11 & 19 & 19 \\
\hline 8 & 49 & 49 & 19 & 19 & 11 & 11 & 19 & 19 \\
\hline
\end{tabular}

a. These recommendations are based on the assumption that no structural modification are needed to accommodate the added insulation.

b. $\quad R$-value of full wall insulation, which is $31 / 2$ inches thick, will depend on material used. Range is $R-11$ to $R-13$. For new construction R-19 is recommended for exterior walls. Jamming an R-19 batt in a $3 \frac{1}{2}$ inch cavity will not yield $R-19$.

c. Insulate crawl space walls only if the crawl space is dry all year, the floor above is not insulated, and all ventilation to the crawl space is blocked. A vapor barrier (e.g. 4- or 6mil polyethylene film) should be installed on the ground to reduce moisture migration into the crawl space.

is now recommended by DOE for use in evaluating energy-saving investments. The lower rate reflects benefits associated with energy conservation that are not explicitly calculated, such as reductions in air and water pollution and a reduction in oil imports. The lower discount factor increases the perceived value of future savings, thus offsetting the effect of the lower fuel price escalation projections.

The procedure for mapping the data from Table 10 to produce Fig. 2 involved several steps because mapping coordinates for the boundaries of the 3-digit zip code areas were unavailable. First, a mapping program was chosen that included the coordinates for all state and 
county boundaries and many city locations. Second, a city was assigned for each of the 3-digit zip codes, thus associating that city with an insulation zone. Third, the city assignments were mapped onto their corresponding counties, using the higher level recommendation whenever two or more cities with different recommendations were located in the same county. The resulting map contained blank areas, or areas with no assigned insulation group, because they were outside the selected county/city boundaries. Therefore, a fourth step used an algorithm that compared values within adjoining polygons to assign insulation levels to these blank areas. Again, the choice was made to use the higher insulation level whenever an unassigned area touched areas of differing levels.

The fact sheet includes a short discussion about the effectiveness of placing new insulation on top of existing insulation in attics. This discussion recognizes that the older insulation is likely to be somewhat compressed, thus losing some part of its effective insulating value. The fact sheet's recommendation that additional insulation be used to compensate for insulation compression is based on experimental work described in Reference 20.

The duct insulation level recommendation of R4 or R6 found in the text of the Fact Sheet was based on ASHRAE 90.2. ${ }^{4}$

Changing the duct efficiency from 0.75 to 1.0 , i.e., assuming that the ducts are located in conditioned space or that a ductless heating system is used, would reduce savings associated with any insulation installation. The savings reduction could in turn change the selection of the recommended insulation levels. To examine this issue, a second ZIP-Code calculation for attic insulation was made for both new and existing homes with gas furnaces, but assuming that there were no duct losses. These results were then compared to the original values (which were based on a duct efficiency of $75 \%$ ) to see what portion of the assigned R-values would be changed. Table 16 shows that $98 \%$ of the R-38 attic recommendations for existing gas-heated homes would be unchanged if there were no duct losses. All of the R-30 recommendations would be reduced to $\mathrm{R}-19$, but this affects less than $2 \%$ of the existing houses (because $53 \%$ of existing houses have gas heat and only about $4 \%$ of the 3-digit Zip Codes are in group E2). For new homes, the impact is greater because about half of the $\mathrm{R}-49$ attic recommendations would be reduced to $\mathrm{R}-38$. This would affect about $40 \%$ of the new homes built (because $46 \%$ of new 
homes have gas heat and about $87 \%$ of the 3-digit Zip Codes are in groups N5, N6, or N7).

Table 16. Effect of duct efficiency on recommended attic insulation levels

\begin{tabular}{|c|c|c|}
\hline \multirow{2}{*}{$\begin{array}{l}\text { Optimal attic insulation level } \\
\text { for } \eta_{\text {duct }}=0.75 \\
{\left[\mathrm{R} \text {-value }\left({ }^{\circ} \mathrm{F} \cdot \mathrm{ft}^{2} \bullet \mathrm{h} / \mathrm{Btu}\right)\right]}\end{array}$} & \multicolumn{2}{|c|}{ Effect on selected optimal attic insulation level if $\eta_{\text {duct }}=1.0$} \\
\hline & Lower & Same \\
\hline \multicolumn{3}{|c|}{ Existing gas-heated homes } \\
\hline 19 & & $100 \%$ \\
\hline 30 & $100 \%$ & \\
\hline 38 & $2 \%$ & $98 \%$ \\
\hline 49 & $2 \%$ & $98 \%$ \\
\hline \multicolumn{3}{|c|}{ New construction gas-heated homes } \\
\hline 22 & $46 \%$ & $54 \%$ \\
\hline 38 & $15 \%$ & $85 \%$ \\
\hline 49 & $50 \%$ & $50 \%$ \\
\hline
\end{tabular}

The breakdown in residential end-use consumption discussed in the fact sheet's introduction is based on data summarized in Ref. 21. Ranges are shown to reflect the variations due to climate and household differences.

The DOE Insulation Fact Sheet was sent in draft form to 41 persons or institutions for review. Many helpful comments were received. In some cases, the suggestions from one reviewer were in opposition to those received from another. The most substantive comments are summarized in Appendix H.

\section{Conclusions}

Insulation differs from many other homeowner purchases - it is seldom bought because of changes in fashion, it doesn't wear out or break, it offers no additional convenience to the homeowner. Few people buy insulation out of an altruistic desire to increase their nation's energy independence or to improve the earth's environment. Consumers purchase insulation because of its perceived value as either a wise investment or a comfort enhancer. Insulation's investment value should be assessed on a life-cycle cost basis, but many homeowners lack the resources to make this evaluation. It is therefore important that the DOE provide clear and 
reasonable guidance in the field of home insulation. It would obviously be best if each consumer had access to a specific survey and calculation for their own home, accounting for their own utility costs, heating and cooling system efficiency, et cetera. The DOE is facilitating such an evaluation by making a user-friendly version of the ZIP-Code computer program available on the Internet. ${ }^{2}$ For consumers without computer resources however, the printed DOE Insulation Fact Sheet offers a useful tool to help them select the appropriate level of insulation for their home. 


\section{References}

1. Insulation Fact Sheet, DOE/CE-0180, January 1988, Department of Energy, Assistant Secretary Conservation and Renewable Energy, U.S. Government Printing Office, Washington, DC

2. Insulation Fact Sheet, DOE/CE-0180, August, 1997, Department of Energy, Assistant Secretary Conservation and Renewable Energy, U.S. Government Printing Office, Washington, DC (http://www.ornl.gov/roofs+walls)

3. Stephen R. Petersen, ZIP - The ZIP-Code Insulation Program (Version 1.0) Economic Insulation Levels for New and Existing Houses by Three-Digit ZIP Code, Users Guide and Reference Manual, ORNL/TM-1109, NISTIR 88-3801, Oak Ridge National Laboratory, Oak Ridge, TN, January 1989

4. ASHRAE Standard 90.2-1993, Energy-Efficient Design of New Low-Rise Residential Buildings, American Society of Heating, Refrigerating, and Air-Conditioning Engineers, Inc., Atlanta GA, 1993

5. Jeff Christian, personal communication from Escher Kwaller, based on California Buildings Duct Leakage Study, Oak Ridge National Laboratory, September 1996

6. Lawrence Berkeley Laboratory, PEAR .1: Program for Energy Analysis of Residences, Berkeley, California, 1987

7. J. Christian and W. Strzepek, "Procedure for Determining the Optimum Foundation Insulation Levels for New, Low-Rise Residential Buildings," ASHRAE Transactions, Vol. 93, Part 1, 1987

8. 1993 ASHRAE Handbook, Fundamentals, American Society of Heating, Refrigerating and Air Conditioning Engineers, Inc., Atlanta GA, 1993

9. J.D. Ned Nisson, Ed., “ 'Ghost Mark' Prevention on Steel-Framed Walls”, Energy Design Update, New York, New York, April, 1995

10. Merle F. McBride, Ph.D., "Thermal Performance of Steel Truss Framed Ceilings and Steel Floor Joists", Owens Corning Science and Technology Center, Granville OH, Draft, Dec. 20, 1996

11. P. R. Waier, Senior Editor, Means Facilities Construction Cost Data, 11th Annual Edition, R. S. Means, Inc., Kingston, MA, 1996

12. Stephen R. Petersen, Energy Price Indices and Discount Factors for Life-Cycle Cost Analysis 1997, NISTIR 85-3273-11 (Revised 7/96), Annual supplement to NIST Handbook 135 and NBS Special Publication 709, U.S. Department of Commerce, Washington, DC, July 1996 
13. ELECTRIC POWER MONTHLY, January 1997, Energy Information Administration, Washington, DC, 1997

14. NATURAL GAS MONTHLY, January 1997, Energy Information Administration, Washington, DC, 1997

15. PETROLEUM MARKETING MONTHLY, February 1997, Energy Information Administration, Washington, DC, 1997

16. Monthly Energy Review, October 1996, DOE/EIA-003J(96/10), Energy Information Administration, Washington, DC, 1996

17. Housing Characteristics 1993, DOE/EIA-0314(93), Energy Information Administration, Washington, DC, June 1995

18. Model Energy Code, Council of American Building Officials, Falls Church, VA 22041

19. John Carmody, Jeffrey Christian, Kenneth Labs, Builder's Foundation Handbook, ORNL/CON-295, Oak Ridge National Laboratory, Oak Ridge, TN, May 1991

20. D. W. Yarbrough and J. H. Wright, Reduction in the Thermal Resistance (R-Value) of Loose-Fill Insulation and Fiberglass Batts Due to Compression, ORNL/Sub-7715/2, Oak Ridge National Laboratory, Oak Ridge TN., April, 1981

21. Household Energy Consumption and Expenditures 1993, DOE/EIA-0321(93), Energy Information Administration, Washington D.C., October 1995

22. PIMA Case Study Residential Wall Sheathing, prepared by Energy Conservation Management, Inc., Baltimore MD, November 1996 


\section{INTERNAL DISTRIBUTION}

1-2. Central Research Library

3-4. Laboratory Records Department

5. Laboratory Records, ORNL RC

6. ORNL Patent Section

7-8. Mary Upton

9. C. Schaffhauser

10. J. E. Christian

11. G. E. Courville

12. A. O. Desjarlais

13. J. Van Coevering

14. T. D. Burchell

15. J. L. Bailey

16. W. A. Gabbard

17. J. W. Klett

18. R. A. Lowden

19. D. J. McGuire

20. R. L. Beatty
21. M. R. Rogers

22. G. R. Romanoski

23. L. L. Snead

24. T. K. Stovall

25. J. P. Strizak

26 K. E. Wilkes

27. A. M. Williams

28. N. L. Vaughn

29. D. W. Yarbrough

30. M. Brown

31. K. Childs

32. K. Cutshaw

33. R. Griffin

34. B. Hopwood

35. P. Love

36. P. Childs

37. J. Kosny

38. T. Petrie

\section{EXTERNAL DISTRIBUTION}

39. Phil Shepard, 606 Bainbridge Drive, E. Lansing, MI 48823-1928

40. Jeffrey Johnson, Pacific Northwest National Laboratory, P.O. Box 999, K5-16, Richland, WA 99352

41. Celina Atkinson, Lawrence Berkeley National Laboratory, 1 Cyclotron Road, Building 90-4000, Berkeley, CA 94720

42. Steven Mumford, BH\&G, 1716 Locust Street, Des Moines, IA 50309-3023

43. Robert Lucas, MSK5-16, Battelle, P.O. Box 999, Richland, WA 99352

44. Lance Berrenberg, American Polysteel, 5150 F Edith, N.E., Albuquerque, NM 87107

45. Jared Blum, Polyisocyanurate Manufacturer's Assoc., 1001 Pennsylvania Avenue N.W., $5^{\text {th }}$ Floor, Washington, DC 20004

46. Ahrun Vohra, Department of Energy, EE-532, 5G-023/FORS, 1000 Independence Ave., S.W., Washington, DC 20585

47. Donald Clem, Steven Winter Associates, Inc., 50 Washington Street, Norwalk, CT 06854

48. Dave Conover, Chairman of ASHRAE 90.2 Committee, PNL Washington Office, 901 D Street S.W., Suite 900, Washington, DC 20024

49. Rick Davenport, Louisiana-Pacific Corp., 77825 Trade Street, Suite 100, San Diego, CA 92121

50. Steve Gerber, Greenstone Industries, 6500 Rock Spring Drive, Suite 400, Bethesda, MD 20817

51. Richard D. Godfrey, Owens-Corning Science \& Technology Center, 2790 Columbus Road, Route 16, Granville, $\mathrm{OH}$ 43023-1200

52. Bert Goldberg, National Association of Home Builders, National Research Center, 400 Prince Georges Blvd., Upper Marlboro, MD 20772-8731

53. Ronald S. Graves, R \& D Services, Inc., 1770 Spring Rd., Lenoir City, TN 37771

54. Tom Greely, BASF, 3000 Continental Drive, N., Mt. Olive, NJ 07828-1234

55. Stephen Braun, Technical Services, North American Insulation Manufacturers Association, 44 Canal Center Plaza, Suite 310, Alexandria, VA 22314

56. Doug Burch, NIST, Building 226, RM B320, Gaithersburg, MD 20899-0001 
57. David Dacquisto, National Association of Home Builders Research Center, 400 Prince Georges Boulevard, Upper Marlboro, MD 20772-8731

58. William Freeborne, Dept. of Housing \& Urban Development, 451 Seventh Street, SW, Room 8132, Washington, DC 20410

59. Paul Hesse, Energy Efficiency and Renewable Energy Clearing House, P.O. Box 3048, Merrifield, VA 22116

60. John F. Hogan, City of Seattle Dept. of Construction and Land Use, 710 2nd Avenue, Suite 700; Seattle, WA 98104-1703

61. Jonathan Humble, American Iron and Steel Institute, 45 South Main Street, Suite 312, P.O. Box 270008, West Hartford, CT 06127-0008

62. Michael Kwart, Insulation Contractors Association of America, 1321 Duke Street, Suite 303, Alexandria, VA 22314

63. Myron B. Lacher, Certainteed Corp., 750 E. Swedesford Road, Valley Forge, PA 19482-0860

64. Daniel Lea, Cellulose Insulation Manufacturers Association, 136 South Keowee Street, Dayton, $\mathrm{OH} 45402$

65. Merle McBride, ASHRAE 90.2 Committee, Owens-Corning Science \& Technology Center, 2790

Columbus Road, Route 16, Granville, $\mathrm{OH}$ 43023-1200

66. David L. McElroy, 7914 Gleason Drive, \#1069, Knoxville, TN 37919-5477

67. Steven Petersen, NIST, Office of Applied Economics, Building and Fire Research Lab., Gaithersburg, MD 20899-0001

68. Richard J. Ray, Schuller International Inc., 10100 W. Ute Avenue, Littleton, CO 80127-5002

69. Russell Roading, Structural Insulated Panel Association, 1511 K Street N.W., Suite 600, Washington, DC 20005

70. William B. Rose, Small Homes Council, Building Research Council, University of Illinois at Urbana-Champaign, One East St. Mary's Road, Champaign, IL 61820

71. Pat Rynd, Owens Corning, Specialty \& Foam Products Division, Technology Center, 275 Southwest Avenue, Tallmadge, $\mathrm{OH} 44278-2232$

72. Tom Savoy, AFM Corporation, 24000 W. Hwy 7, P.O. Box 246, Excelsior, MN 55331

73. George H. Sievert, Spray Polyurethane Foam Industry Facilitator, Management Resource Associates, 13630 Watertower Circle, Minneapolis, MN 55441

74. Peter Stratton, Steven Winter Associates, Inc., 50 Washington Street, Norwalk, CT 06854

75. Bill Strzepek, Dow Chemical, P.O. Box 515, Granville, OH 43023

76. John Talbot, Office of Building Systems, U.S. Department of Energy, EE-41, 6A-116/FORS, 1000 Independence Avenue, S.W., Washington, DC 20585

77. Adrian Tuluca, Steven Winter Associates, Inc., 50 Washington Street, Norwalk, CT 06854

78. Stephen Turchen, U.S. Department of Energy, EE-43, 6A-116/FORS, 1000 Independence Avenue, S.W., Washington, DC 20585

79. Dick Whitaker, Insulating Concrete Form Association, 960 Harlem Ave, Suite 1128, Glenview, IL 60025

80. Ned Nisson, Energy Design Update, 235 W. 102nd Street \#7J, New York, NY 10025

81. Bill Lippy, Fi-Foil Company, 612 Bridgers Ave. West, Auburndale, FL 33823

82. Dan Russell, Innovative Insulation, Inc., 6200 W. Pioneer Pkwy., Arlington, TX 76013

83. Alex Wilson, Editor, Environmental Building News, RR1, Box 161, Battleboro VT 05301

84. Wes Hall, Solar Shield, Inc., 1264 Old Alpharetta Road, Alpharetta GA 30202

85. Steven Bodzin, Assoc. Editor, Home Energy, 2124 Kittredge Street, \#95, Berkeley, CA 94704

86. Dale Rammien, Director, Home Ventilating Institute, 30 West University Dr., Arlington Heights, IL 60004

87. Dick Morris, National Association of Home Builders, $120115^{\text {th }}$ Street, N.W., Washington, DC 20005

88. Ford Blake, Home Insulation, 500 Circle Dr., Casper, WY 82601

89. Roger Thies, 104 Engineering Unit A, Pennsylvania State University, University Park, PA 16802

90. Reflective Insulation Manufacturers Assoc., P.O. Box 90955, Washington, DC 20090

91. Laurence F. Kinney, Synertech Systems Corp., 472 S. Salina Street, Suite 410, Syracuse, NY 13202-2401

92. Lena Nirk, U.S.E.P.A. (6202J), 401 M Street, S.W., Washington, DC 20460 


\section{Appendix A: Climate and Cost Information Used in The Zip Computer Program.}

The data values shown in this table include the 3-digit zip code (i.e., the first three digits of a five digit postal zip code), the fuel escalation region, and the state number, which is used to reference energy prices and insulation cost adjustment factors. Climate values for heating (HDDk $=$ heating degree days divided by 1000 , base $\left.65^{\circ} \mathrm{F}\right)$ and cooling $\left(\mathrm{CDHk}=\right.$ cooling degree hours divided by 1000 , base $\left.74^{\circ} \mathrm{F}\right)$ are also shown.

\begin{tabular}{|c|c|c|c|c|c|c|}
\hline $\begin{array}{c}\text { Zip } \\
\text { Code }\end{array}$ & City & State & HDDk & CDHk & $\begin{array}{c}\text { Fuel } \\
\text { escalation } \\
\text { region }\end{array}$ & $\begin{array}{c}\text { State } \\
\text { No. }\end{array}$ \\
\hline 001 & Not used & 00 & 0.0 & 0.0 & 0 & 0 \\
\hline 002 & Not used & 00 & 0.0 & 0.0 & 0 & 0 \\
\hline 003 & Not used & 00 & 0.0 & 0.0 & 0 & 0 \\
\hline 004 & Not used & 00 & 0.0 & 0.0 & 0 & 0 \\
\hline 005 & Not used & 00 & 0.0 & 0.0 & 0 & 0 \\
\hline 006 & Not used & 00 & 0.0 & 0.0 & 0 & 0 \\
\hline 007 & Not used & 00 & 0.0 & 0.0 & 0 & 0 \\
\hline 008 & Not used & 00 & 0.0 & 0.0 & 0 & 0 \\
\hline 009 & Not used & 00 & 0.0 & 0.0 & 0 & 0 \\
\hline 010 & Springfield & MA & 6.0 & 5.2 & 1 & 22 \\
\hline 011 & Springfield & MA & 6.0 & 5.2 & 1 & 22 \\
\hline 012 & Pittsfield & MA & 7.3 & 1.2 & 1 & 22 \\
\hline 013 & Greenfield & MA & 6.6 & 2.9 & 1 & 22 \\
\hline 014 & Worcester & MA & 7.0 & 1.5 & 1 & 22 \\
\hline 015 & Worcester & MA & 7.0 & 1.5 & 1 & 22 \\
\hline 016 & Worcester & MA & 7.0 & 1.5 & 1 & 22 \\
\hline 017 & Framing- & MA & 6.2 & 4.2 & 1 & 22 \\
\hline 018 & Woburn & MA & 6.2 & 3.6 & 1 & 22 \\
\hline 019 & Lynn & MA & 6.1 & 2.8 & 1 & 22 \\
\hline 020 & Boston & MA & 5.6 & 5.4 & 1 & 22 \\
\hline 021 & Boston & MA & 5.6 & 5.4 & 1 & 22 \\
\hline 022 & Boston & MA & 5.6 & 5.4 & 1 & 22 \\
\hline 023 & Brockton & MA & 6.0 & 3.4 & 1 & 22 \\
\hline 024 & Brockton & MA & 6.0 & 3.4 & 1 & 22 \\
\hline
\end{tabular}

\begin{tabular}{|c|c|c|c|c|c|c|}
\hline 025 & $\begin{array}{c}\text { Buzzards } \\
\text { Bay }\end{array}$ & $\mathrm{MA}$ & 6.3 & 2.4 & 1 & 22 \\
\hline 026 & Hyannis & $\mathrm{MA}$ & 6.0 & 2.0 & 1 & 22 \\
\hline 027 & $\begin{array}{c}\text { New } \\
\text { Bedford }\end{array}$ & $\mathrm{MA}$ & 5.3 & 6.4 & 1 & 22 \\
\hline 028 & Providence & $\mathrm{RI}$ & 5.9 & 3.6 & 1 & 40 \\
\hline 029 & Providence & $\mathrm{RI}$ & 5.9 & 3.6 & 1 & 40 \\
\hline 030 & Manchester & $\mathrm{NH}$ & 7.1 & 1.6 & 1 & 30 \\
\hline 031 & Manchester & $\mathrm{NH}$ & 7.1 & 1.6 & 1 & 30 \\
\hline 032 & Pittsfield & $\mathrm{NH}$ & 7.4 & 2.0 & 1 & 30 \\
\hline 033 & Concord & $\mathrm{NH}$ & 7.4 & 2.0 & 1 & 30 \\
\hline 034 & Keene & $\mathrm{NH}$ & 7.0 & 2.2 & 1 & 30 \\
\hline 035 & Littleton & $\mathrm{NH}$ & 8.6 & 1.2 & 1 & 30 \\
\hline 036 & Acworth & $\mathrm{NH}$ & 7.0 & 2.2 & 1 & 30 \\
\hline 037 & Claremont & $\mathrm{NH}$ & 7.9 & 1.7 & 1 & 30 \\
\hline 038 & Portsmouth & $\mathrm{NH}$ & 6.9 & 2.2 & 1 & 30 \\
\hline 039 & Kittery & $\mathrm{ME}$ & 6.9 & 2.2 & 1 & 20 \\
\hline 040 & Portland & $\mathrm{ME}$ & 7.5 & 1.1 & 1 & 20 \\
\hline 041 & Portland & $\mathrm{ME}$ & 7.5 & 1.1 & 1 & 20 \\
\hline 042 & Auburn & $\mathrm{ME}$ & 7.4 & 2.3 & 1 & 20 \\
\hline 043 & Augusta & $\mathrm{ME}$ & 7.6 & 2.2 & 1 & 20 \\
\hline 044 & Bangor & $\mathrm{ME}$ & 8.0 & 1.2 & 1 & 20 \\
\hline 045 & Bath & $\mathrm{ME}$ & 7.5 & 1.1 & 1 & 20 \\
\hline 046 & Ellsworth & $\mathrm{ME}$ & 7.2 & 1.0 & 1 & 20 \\
\hline 047 & Caribou & $\mathrm{ME}$ & 9.6 & 0.9 & 1 & 20 \\
\hline 048 & Rockland & $\mathrm{ME}$ & 7.3 & 1.0 & 1 & 20 \\
\hline 049 & Waterville & $\mathrm{ME}$ & 7.5 & 1.8 & 1 & 20 \\
\hline 050 & White River & $\mathrm{VT}$ & 8.3 & 1.1 & 1 & 46 \\
\hline Junct. & & & & & \\
\hline
\end{tabular}




\begin{tabular}{|c|c|c|c|c|c|c|}
\hline $\begin{array}{l}\text { Zip } \\
\text { Code }\end{array}$ & City & State & HDDk & CDHk & $\begin{array}{c}\text { Fuel } \\
\text { escalation } \\
\text { region }\end{array}$ & $\begin{array}{l}\text { State } \\
\text { No. }\end{array}$ \\
\hline 051 & $\begin{array}{l}\text { Bellows } \\
\text { Falls }\end{array}$ & VT & 7.4 & 2.2 & 1 & 46 \\
\hline 052 & Bennington & VT & 7.6 & 0.8 & 1 & 46 \\
\hline 053 & Brattleboro & VT & 7.2 & 2.2 & 1 & 46 \\
\hline 054 & Burlington & VT & 8.0 & 2.6 & 1 & 46 \\
\hline 055 & Not used & 00 & 0.0 & 0.0 & 0 & 0 \\
\hline 056 & Montpelier & VT & 8.5 & 1.4 & 1 & 46 \\
\hline 057 & Rutland & VT & 7.2 & 1.8 & 1 & 46 \\
\hline 058 & $\begin{array}{c}\text { St. } \\
\text { Johnsbury }\end{array}$ & VT & 7.9 & 1.9 & 1 & 46 \\
\hline 059 & Canaan & VT & 8.7 & 1.5 & 1 & 46 \\
\hline 060 & Hartford & $\mathrm{CT}$ & 6.2 & 4.8 & 1 & 7 \\
\hline 061 & Hartford & $\mathrm{CT}$ & 6.2 & 4.8 & 1 & 7 \\
\hline 062 & Willimantic & $\mathrm{CT}$ & 6.5 & 1.3 & 1 & 7 \\
\hline 063 & $\begin{array}{l}\text { New } \\
\text { London }\end{array}$ & $\mathrm{CT}$ & 6.0 & 5.0 & 1 & 7 \\
\hline 064 & New Haven & $\mathrm{CT}$ & 6.0 & 5.0 & 1 & 7 \\
\hline 065 & New Haven & $\mathrm{CT}$ & 6.0 & 5.0 & 1 & 7 \\
\hline 066 & Bridgeport & $\mathrm{CT}$ & 5.5 & 5.0 & 1 & 7 \\
\hline 067 & Waterbury & $\mathrm{CT}$ & 6.5 & 2.0 & 1 & 7 \\
\hline 068 & Stamford & $\mathrm{CT}$ & 5.9 & 3.6 & 1 & 7 \\
\hline 069 & Stamford & $\mathrm{CT}$ & 5.9 & 3.6 & 1 & 7 \\
\hline 070 & Newark & NJ & 5.0 & 9.1 & 1 & 31 \\
\hline 071 & Newark & $\mathrm{NJ}$ & 5.0 & 9.1 & 1 & 31 \\
\hline 072 & Elizabeth & $\mathrm{NJ}$ & 5.0 & 9.1 & 1 & 31 \\
\hline 073 & Jersey City & $\mathrm{NJ}$ & 5.3 & 7.0 & 1 & 31 \\
\hline 074 & Paterson & $\mathrm{NJ}$ & 5.4 & 6.1 & 1 & 31 \\
\hline 075 & Paterson & $\mathrm{NJ}$ & 5.4 & 6.1 & 1 & 31 \\
\hline 076 & Hackensack & NJ & 5.4 & 6.1 & 1 & 31 \\
\hline 077 & Red Bank. & $\mathrm{NJ}$ & 5.3 & 5.4 & 1 & 31 \\
\hline 078 & Dover & $\mathrm{NJ}$ & 6.3 & 3.1 & 1 & 31 \\
\hline 079 & Summit & $\mathrm{NJ}$ & 5.9 & 4.0 & 1 & 31 \\
\hline 080 & Cherry Hill & $\mathrm{NJ}$ & 5.2 & 7.9 & 1 & 31 \\
\hline
\end{tabular}

\begin{tabular}{|c|c|c|c|c|c|c|}
\hline 081 & Camden & $\mathrm{NJ}$ & 5.0 & 8.9 & 1 & 31 \\
\hline 082 & South Jersey & $\mathrm{NJ}$ & 4.9 & 7.4 & 1 & 31 \\
\hline 083 & South Jersey & $\mathrm{NJ}$ & 4.9 & 7.4 & 1 & 31 \\
\hline 084 & $\begin{array}{l}\text { Atlantic } \\
\text { City }\end{array}$ & $\mathrm{NJ}$ & 4.9 & 6.0 & 1 & 31 \\
\hline 085 & Trenton & $\mathrm{NJ}$ & 5.0 & 7.4 & 1 & 31 \\
\hline 086 & Trenton & $\mathrm{NJ}$ & 5.0 & 7.4 & 1 & 31 \\
\hline 087 & Lakewood & NJ & 5.3 & 5.4 & 1 & 31 \\
\hline 088 & $\begin{array}{c}\text { New } \\
\text { Brunswick }\end{array}$ & $\mathrm{NJ}$ & 5.2 & 5.4 & 1 & 31 \\
\hline 089 & $\begin{array}{c}\text { New } \\
\text { Brunswick }\end{array}$ & $\mathrm{NJ}$ & 5.2 & 5.4 & 1 & 31 \\
\hline 090 & Not used & 00 & 0.0 & 0.0 & 0 & 0 \\
\hline 091 & Not used & 00 & 0.0 & 0.0 & 0 & 0 \\
\hline 092 & Not used & 00 & 0.0 & 0.0 & 0 & 0 \\
\hline 093 & Not used & 00 & 0.0 & 0.0 & 0 & 0 \\
\hline 094 & Not used & 00 & 0.0 & 0.0 & 0 & 0 \\
\hline 095 & Not used & 00 . & 0.0 & 0.0 & 0 & 0 \\
\hline 096 & Not used & 00 & 0.0 & 0.0 & 0 & 0 \\
\hline 097 & Not used & 00 & 0.0 & 0.0 & 0 & 0 \\
\hline 098 & Not used & 00 & 0.0 & 0.0 & 0 & 0 \\
\hline 099 & Not used & 00 & 0.0 & 0.0 & 0 & 0 \\
\hline 100 & New York & NY & 4.9 & 9.5 & 1 & 33 \\
\hline 101 & New York & NY & 4.9 & 9.5 & 1 & 33 \\
\hline 102 & New York & NY & 4.9 & 9.5 & 1 & 33 \\
\hline 103 & $\begin{array}{l}\text { Staten } \\
\text { Island }\end{array}$ & NY & 5.0 & 7.0 & 1 & 33 \\
\hline 104 & Bronx & NY & 4.9 & 9.2 & 1 & 33 \\
\hline 105 & Westchester & NY & 5.4 & 5.4 & 1 & 33 \\
\hline 106 & White Plains & NY & 5.4 & 5.4 & 1 & 33 \\
\hline 107 & Yonkers & NY & 5.4 & 5.4 & 1 & 33 \\
\hline 108 & $\begin{array}{c}\text { New } \\
\text { Rochelle }\end{array}$ & NY & 5.4 & 5.4 & 1 & 33 \\
\hline 109 & Suffern & NY & 5.7 & 6.1 & 1 & 33 \\
\hline
\end{tabular}




\begin{tabular}{|c|c|c|c|c|c|c|}
\hline$\underset{\text { Code }}{\text { Zip }}$ & City & State & HDDk & $\mathrm{CDHk}$ & $\begin{array}{c}\text { Fuel } \\
\text { escalation } \\
\text { region }\end{array}$ & $\begin{array}{l}\text { State } \\
\text { No. }\end{array}$ \\
\hline 110 & Great Neck & NY & 5.0 & 9.2 & 1 & 33 \\
\hline 111 & Queens & NY & 5.0 & 9.2 & 1 & 33 \\
\hline 112 & Brooklyn & NY & 5.0 & 7.6 & 1 & 33 \\
\hline 113 & Flushing & NY & 5.0 & 7.6 & 1 & 33 \\
\hline 114 & Jamaica & NY & 5.2 & 7.6 & 1 & 33 \\
\hline 115 & Minneola & NY & 5.2 & 7.4 & 1 & 33 \\
\hline 116 & $\begin{array}{c}\text { Far } \\
\text { Rockaway }\end{array}$ & NY & 5.0 & 7.6 & 1 & 33 \\
\hline 117 & Hicksville & NY & 5.2 & 7.4 & 1 & 33 \\
\hline 118 & Hicksville & NY & 5.2 & 7.4 & 1 & 33 \\
\hline 119 & Riverhead & $\mathrm{NY}$ & 5.3 & 4.7 & 1 & 33 \\
\hline 120 & Albany & NY & 6.9 & 3.0 & 1 & 33 \\
\hline 121 & Albany & $\mathrm{NY}$ & 6.9 & 3.0 & 1 & 33 \\
\hline 122 & Albany & NY & 6.9 & 3.0 & 1 & 33 \\
\hline 123 & Schenectady & $\mathrm{NY}$ & 7.0 & 3.0 & 1 & 33 \\
\hline 124 & Kingston & NY & 6.4 & 4.3 & 1 & 33 \\
\hline 125 & $\begin{array}{c}\text { Poughkeep- } \\
\text { sie }\end{array}$ & NY & 6.4 & 4.3 & 1 & 33 \\
\hline 126 & $\begin{array}{l}\text { Poughkeep- } \\
\text { sie }\end{array}$ & NY & 6.4 & 4.3 & 1 & 33 \\
\hline 127 & Monticello & $\mathrm{NY}$ & 7.5 & 0.8 & 1 & 33 \\
\hline 128 & Glens Falls & $\mathrm{NY}$ & 7.5 & 2.0 & 1 & 33 \\
\hline 129 & Plattsburgh & $\mathrm{NY}$ & 7.8 & 1.9 & 1 & 33 \\
\hline 130 & Syracuse & $\mathrm{NY}$ & 6.8 & 3.5 & 1 & 33 \\
\hline 131 & Syracuse & NY & 6.8 & 3.5 & 1 & 33 \\
\hline 132 & Syracuse & $\mathrm{NY}$ & 6.8 & 3.5 & 1 & 33 \\
\hline 133 & Utica & NY & 7.4 & 2.7 & 1 & 33 \\
\hline 134 & Utica & NY & 7.4 & 2.7 & 1 & 33 \\
\hline 135 & Utica & NY & 7.4 & 2.7 & 1 & 33 \\
\hline 136 & Watertown & NY & 7.5 & 2.7 & 1 & 33 \\
\hline 137 & Binghamton & NY & 7.3 & 1.6 & 1 & 33 \\
\hline 138 & Binghamton & NY & 7.3 & 1.6 & 1 & 33 \\
\hline 139 & Binghamton & NY & 7.3 & 1.6 & 1 & 33 \\
\hline
\end{tabular}

\begin{tabular}{|c|c|c|c|c|c|c|}
\hline 140 & Buffalo & NY & 6.8 & 3.0 & 1 & 33 \\
\hline 141 & Buffalo & NY & 6.8 & 3.0 & 1 & 33 \\
\hline 142 & Buffalo & NY & 6.8 & 3.0 & 1 & 33 \\
\hline 143 & $\begin{array}{c}\text { Niagara } \\
\text { Falls }\end{array}$ & NY & 6.8 & 3.0 & 1 & 33 \\
\hline 144 & Rochester & NY & 6.7 & 3.8 & 1 & 33 \\
\hline 145 & Rochester & NY & 6.7 & 3.8 & 1 & 33 \\
\hline 146 & Rochester & NY & 6.7 & 3.8 & 1 & 33 \\
\hline 147 & Jamestown & NY & 7.4 & 3.7 & 1 & 33 \\
\hline 148 & Ithaca & NY & 7.1 & 1.6 & 1 & 33 \\
\hline 149 & Elmira & NY & 6.9 & 2.5 & 1 & 33 \\
\hline 150 & Pittsburgh & PA & 6.0 & 5.0 & 1 & 39 \\
\hline 151 & Pittsburgh & PA & 6.0 & 5.0 & 1 & 39 \\
\hline 152 & Pittsburgh & PA & 6.0 & 5.0 & 1 & 39 \\
\hline 153 & Washington & PA & 5.9 & 3.9 & 1 & 39 \\
\hline 154 & Uniontown & PA & 5.4 & 6.2 & 1 & 39 \\
\hline 155 & Somerset & PA & 6.0 & 6.1 & 1 & 39 \\
\hline 156 & Greensburg & PA & 7.0 & 2.4 & 1 & 39 \\
\hline 157 & Indiana & PA & 6.2 & 2.6 & 1 & 39 \\
\hline 158 & Du Bois & PA & 7.2 & 1.8 & 1 & 39 \\
\hline 159 & Johnstown & PA & 5.8 & 5.7 & 1 & 39 \\
\hline 160 & Butler & PA & 6.5 & 4.7 & 1 & 39 \\
\hline 161 & New Castle & PA & 5.9 & 4.8 & 1 & 39 \\
\hline 162 & Kittanning & PA & 6.8 & 2.5 & 1 & 39 \\
\hline 163 & Oil City & PA & 6.6 & 2.8 & 1 & 39 \\
\hline 164 & Erie & PA & 6.8 & 2.2 & 1 & 39 \\
\hline 165 & Erie & PA & 6.8 & 2.2 & 1 & 39 \\
\hline 166 & Altoona & PA & 7.4 & 1.5 & 1 & 39 \\
\hline 167 & Bradford & PA & 8.0 & 0.8 & 1 & 39 \\
\hline 168 & State & PA & 6.3 & 3.5 & 1 & 39 \\
\hline 169 & Wellsboro & PA & 7.7 & 1.4 & 1 & 39 \\
\hline
\end{tabular}




\begin{tabular}{|c|c|c|c|c|c|c|}
\hline$\underset{\text { Code }}{\text { Zip }}$ & City & State & HDDK & CDHk & $\begin{array}{c}\begin{array}{c}\text { Fuel } \\
\text { escalation } \\
\text { region }\end{array} \\
\end{array}$ & $\begin{array}{l}\text { State } \\
\text { No. }\end{array}$ \\
\hline 170 & Harrisburg & PA & 5.3 & 9.1 & 1 & 39 \\
\hline 171 & Harrisburg & PA & 5.3 & 9.1 & 1 & 39 \\
\hline 172 & $\begin{array}{c}\text { Chambers- } \\
\text { burg }\end{array}$ & $\mathrm{PA}$ & 5.6 & 5.4 & 1 & 39 \\
\hline 173 & York & PA & 5.2 & 6.6 & 1 & 39 \\
\hline 174 & York & $\mathrm{PA}$ & 5.2 & 6.6 & 1 & 39 \\
\hline 175 & Lancaster & PA & 5.4 & 6.0 & 1 & 39 \\
\hline 176 & Lancaster & $\mathrm{PA}$ & 5.4 & 6.0 & 1 & 39 \\
\hline 177 & $\begin{array}{l}\text { Williams- } \\
\text { port }\end{array}$ & $\mathrm{PA}$ & 6.1 & 5.0 & 1 & 39 \\
\hline 178 & Sunbury & $\mathrm{PA}$ & 5.8 & 5.3 & 1 & 39 \\
\hline 179 & Pottsville & PA & 6.4 & 3.0 & 1 & 39 \\
\hline 180 & $\begin{array}{l}\text { Lehigh } \\
\text { Valley }\end{array}$ & $\mathrm{PA}$ & 6.0 & 5.5 & 1 & 39 \\
\hline 181 & Allentown & PA & 5.8 & 5.8 & 1 & 39 \\
\hline 182 & Hazleton & PA & 6.9 & 1.7 & 1 & 39 \\
\hline 183 & Stroudsburg & $\mathrm{PA}$ & 6.2 & 5.3 & 1 & 39 \\
\hline 184 & Scranton & $\mathrm{PA}$ & 6.3 & 3.8 & 1 & 39 \\
\hline 185 & Scranton & PA & 6.3 & 3.8 & 1 & 39 \\
\hline 186 & $\begin{array}{c}\text { Wilkes- } \\
\text { Barre }\end{array}$ & PA & 6.3 & 3.8 & 1 & 39 \\
\hline 187 & $\begin{array}{c}\text { Wilkes- } \\
\text { Barre } \\
\end{array}$ & PA & 6.3 & 3.8 & 1 & 39 \\
\hline 188 & Montrose & PA & 7.7 & 1.6 & 1 & 39 \\
\hline 189 & Doylestown & $\mathrm{PA}$ & 5.4 & 6.5 & 1 & 39 \\
\hline 190 & Philadelphia & PA & 5.0 & 8.9 & 1 & 39 \\
\hline 191 & Philadelphia & $\mathrm{PA}$ & 5.0 & 8.9 & 1 & 39 \\
\hline 192 & Not used & 00 & 0.0 & 0.0 & 1 & 0 \\
\hline 193 & $\begin{array}{c}\text { South- } \\
\text { eastern PA }\end{array}$ & PA & 5.0 & 8.9 & 1 & 39 \\
\hline 194 & $\begin{array}{c}\text { South- } \\
\text { eastern PA }\end{array}$ & PA & 5.0 & 8.9 & 1 & 39 \\
\hline 195 & Reading & PA & 5.8 & 4.0 & 1 & 39 \\
\hline 196 & Reading & PA & 5.8 & 4.0 & 1 & 39 \\
\hline 197 & Wilmington & $\mathrm{DE}$ & 5.0 & 8.2 & 3 & 8 \\
\hline
\end{tabular}

\begin{tabular}{|c|c|c|c|c|c|c|}
\hline 198 & Wilmington & $\mathrm{DE}$ & 5.0 & 8.2 & 3 & 8 \\
\hline 199 & Dover & $\mathrm{DE}$ & 4.4 & 9.3 & 3 & 8 \\
\hline 200 & Washington & $\mathrm{DC}$ & 4.2 & 12.4 & 3 & 9 \\
\hline 201 & Washington & $\mathrm{DC}$ & 4.2 & 12.4 & 3 & 9 \\
\hline 202 & Washington & $\mathrm{DC}$ & 4.2 & 12.4 & 3 & 9 \\
\hline 203 & Washington & $\mathrm{DC}$ & 4.2 & 12.4 & 3 & 9 \\
\hline 204 & Washington & $\mathrm{DC}$ & 4.2 & 12.4 & 3 & 9 \\
\hline 205 & Washington & $\mathrm{DC}$ & 4.2 & 12.4 & 3 & 9 \\
\hline 206 & Waldorf & $\mathrm{MD}$ & 4.4 & 8.2 & 3 & 21 \\
\hline 207 & Laurel & $\mathrm{MD}$ & 4.5 & 10.5 & 3 & 21 \\
\hline 208 & Rockville & $\mathrm{MD}$ & 4.7 & 9.8 & 3 & 21 \\
\hline 209 & $\begin{array}{l}\text { Silver } \\
\text { Spring }\end{array}$ & $\mathrm{MD}$ & 4.7 & 9.8 & 3 & 21 \\
\hline 210 & Baltimore & $\mathrm{MD}$ & 4.7 & 9.5 & 3 & 21 \\
\hline 211 & Baltimore & $\mathrm{MD}$ & 4.7 & 9.5 & 3 & 21 \\
\hline 212 & Baltimore & $\mathrm{MD}$ & 4.7 & 9.5 & 3 & 21 \\
\hline 213 & Baltimore & $\mathrm{MD}$ & 4.7 & 9.5 & 3 & 21 \\
\hline 214 & Annapolis & $\mathrm{MD}$ & 4.7 & 9.0 & 3 & 21 \\
\hline 215 & Cumberland & $\mathrm{MD}$ & 5.1 & 7.1 & 3 & 21 \\
\hline 216 & Easton & MD & 4.2 & 11.0 & 3 & 21 \\
\hline 217 & Frederick & $\mathrm{MD}$ & 5.1 & 7.3 & 3 & 21 \\
\hline 218 & Salisbury & $\mathrm{MD}$ & 4.0 & 9.2 & 3 & 21 \\
\hline 219 & Elkton & $\mathrm{MD}$ & 5.2 & 6.6 & 3 & 21 \\
\hline 220 & $\begin{array}{c}\text { Northern } \\
\text { VA }\end{array}$ & VA & 4.2 & 12.4 & 3 & 47 \\
\hline 221 & $\begin{array}{l}\text { Northern } \\
\text { VA }\end{array}$ & VA & 4.2 & 12.4 & 3 & 47 \\
\hline 222 & Arlington & $\mathrm{VA}$ & 4.2 & 12.4 & 3 & 47 \\
\hline 223 & Alexandria & VA & 4.2 & 12.4 & 3 & 47 \\
\hline 224 & $\begin{array}{c}\text { Frederick- } \\
\text { sburg }\end{array}$ & VA & 4.4 & 10.2 & 3 & 47 \\
\hline 225 & $\begin{array}{l}\text { Fredericks- } \\
\text { burg }\end{array}$ & VA & 4.4 & 10.2 & 3 & 47 \\
\hline 226 & Winchester & VA & 4.8 & 8.1 & 3 & 47 \\
\hline
\end{tabular}




\begin{tabular}{|c|c|c|c|c|c|c|}
\hline$\underset{\text { Code }}{\text { Zip }}$ & City & State & HDDk & CDHk & $\begin{array}{c}\text { Fuel } \\
\text { escalation } \\
\text { region }\end{array}$ & $\begin{array}{l}\text { State } \\
\text { No. }\end{array}$ \\
\hline 227 & Culpeper & VA & 4.4 & 8.9 & 3 & 47 \\
\hline 228 & $\begin{array}{l}\text { Harrison- } \\
\text { burg }\end{array}$ & VA & 5.1 & 6.5 & 3 & 47 \\
\hline 229 & $\begin{array}{l}\text { Charlottes- } \\
\text { ville }\end{array}$ & VA & 4.2 & 10.3 & 3 & 47 \\
\hline 230 & Richmond & VA & 4.0 & 12.3 & 3 & 47 \\
\hline 231 & Richmond & VA & 4.0 & 12.3 & 3 & 47 \\
\hline 232 & Richmond & VA & 4.0 & 12.3 & 3 & 47 \\
\hline 233 & Norfolk & VA & 3.5 & 13.7 & 3 & 47 \\
\hline 234 & Norfolk & VA & 3.5 & 13.7 & 3 & 47 \\
\hline 235 & Norfolk & VA & 3.5 & 13.7 & 3 & 47 \\
\hline 236 & Norfolk & VA & 3.5 & 13.7 & 3 & 47 \\
\hline 237 & Portsmouth & VA & 3.5 & 13.7 & 3 & 47 \\
\hline 238 & Petersburg & VA & 3.4 & 14.6 & 3 & 47 \\
\hline 239 & Farmville & VA & 4.0 & 9.4 & 3 & 47 \\
\hline 240 & Roanoke & VA & 4.3 & 9.3 & 3 & 47 \\
\hline 241 & Roanoke & VA & 4.3 & 9.3 & 3 & 47 \\
\hline 242 & Bristol & VA & 3.9 & 8.8 & 3 & 47 \\
\hline 243 & Pulaski & VA & 5.1 & 3.3 & 3 & 47 \\
\hline 244 & Staunton & VA & 5.1 & 6.5 & 3 & 47 \\
\hline 245 & Lynchburg & VA & 4.3 & 8.4 & 3 & 47 \\
\hline 246 & Tazewell & VA & 6.0 & 0.8 & 3 & 47 \\
\hline 247 & Bluefield & WV & 5.2 & 2.6 & 3 & 49 \\
\hline 248 & Welch & WV & 5.1 & 7.9 & 3 & 49 \\
\hline 249 & Lewisburg & WV & 5.3 & 3.7 & 3 & 49 \\
\hline 250 & Charleston & WV & 4.7 & 8.8 & 3 & 49 \\
\hline 251 & Charleston & WV & 4.7 & 8.8 & 3 & 49 \\
\hline 252 & Charleston & wV & 4.7 & 8.8 & 3 & 49 \\
\hline 253 & Charleston & wV & 4.7 & 8.8 & 3 & 49 \\
\hline 254 & Martinsburg & WV & 5.2 & 8.2 & 3 & 49 \\
\hline 255 & Huntington & WV & 4.7 & 11.2 & 3 & 49 \\
\hline 256 & Logan & WV & 5.1 & 7.5 & 3 & 49 \\
\hline
\end{tabular}

\begin{tabular}{|c|c|c|c|c|c|c|}
\hline 257 & Huntington & WV & 4.7 & 11.2 & 3 & 49 \\
\hline 258 & Beckley & WV & 5.6 & 2.1 & 3 & 49 \\
\hline 259 & Beckley & WV & 5.6 & 2.1 & 3 & 49 \\
\hline 260 & Wheeling & WV & 5.5 & 6.8 & 3 & 49 \\
\hline 261 & Parkersburg & WV & 5.0 & 9.1 & 3 & 49 \\
\hline 262 & Buckhannon & WV & 5.4 & 4.0 & 3 & 49 \\
\hline 263 & Clarksburg & WV & 5.5 & 6.4 & 3 & 49 \\
\hline 264 & Clarksburg & WV & 5.5 & 6.4 & 3 & 49 \\
\hline 265 & $\begin{array}{l}\text { Morgan- } \\
\text { town }\end{array}$ & WV & 5.4 & 6.9 & 3 & 49 \\
\hline 266 & Gassaway & WV & 4.8 & 6.3 & 3 & 49 \\
\hline 267 & Keyser & WV & 5.1 & 7.1 & 3 & 49 \\
\hline 268 & Petersburg & WV & 5.5 & 3.8 & 3 & 49 \\
\hline 269 & Not used & 00 & 0.0 & 0.0 & 0 & 0 \\
\hline 270 & $\begin{array}{c}\text { Winston- } \\
\text { Salem }\end{array}$ & $\mathrm{NC}$ & 3.4 & 11.8 & 3 & 34 \\
\hline 271 & $\begin{array}{l}\text { Winston- } \\
\text { Salem }\end{array}$ & $\mathrm{NC}$ & 3.4 & 11.8 & 3 & 34 \\
\hline 272 & Greensboro & $\mathrm{NC}$ & 3.9 & 11.0 & 3 & 34 \\
\hline 273 & Greensboro & $\mathrm{NC}$ & 3.9 & 11.0 & 3 & 34 \\
\hline 274 & Greensboro & $\mathrm{NC}$ & 3.9 & 11.0 & 3 & 34 \\
\hline 275 & Raleigh & $\mathrm{NC}$ & 3.5 & 11.8 & 3 & 34 \\
\hline 276 & Raleigh & $\mathrm{NC}$ & 3.5 & 11.8 & 3 & 34 \\
\hline 277 & Durham & $\mathrm{NC}$ & 3.5 & 11.8 & 3 & 34 \\
\hline 278 & $\begin{array}{l}\text { Rocky } \\
\text { Mount }\end{array}$ & $\mathrm{NC}$ & 3.4 & 13.8 & 3 & 34 \\
\hline 279 & $\begin{array}{l}\text { Elizabeth } \\
\text { City }\end{array}$ & $\mathrm{NC}$ & 3.2 & 14.0 & 3 & 34 \\
\hline 280 & Charlotte & $\mathrm{NC}$ & 3.3 & 15.2 & 3 & 34 \\
\hline 281 & Charlotte & $\mathrm{NC}$ & 3.3 & 15.2 & 3 & 34 \\
\hline 282 & Charlotte & $\mathrm{NC}$ & 3.3 & 15.2 & 3 & 34 \\
\hline 283 & Fayetteville & NC & 3.2 & 15.6 & 3 & 34 \\
\hline 284 & Wilmington & $\mathrm{NC}$ & 2.5 & 17.6 & 3 & 34 \\
\hline 285 & Kinston & $\mathrm{NC}$ & 3.1 & 15.7 & 3 & 34 \\
\hline
\end{tabular}




\begin{tabular}{|c|c|c|c|c|c|c|}
\hline$\underset{\text { Code }}{\text { Zip }}$ & City & State & HDDk & CDHk & $\begin{array}{c}\text { Fuel } \\
\text { escalation } \\
\text { region }\end{array}$ & $\begin{array}{c}\text { State } \\
\text { No. }\end{array}$ \\
\hline 286 & Hickory & $\mathrm{NC}$ & 3.8 & 11.1 & 3 & 34 \\
\hline 287 & Asheville & $\mathrm{NC}$ & 4.1 & 6.2 & 3 & 34 \\
\hline 288 & Asheville & $\mathrm{NC}$ & 4.1 & 6.2 & 3 & 34 \\
\hline 289 & Andrews & $\mathrm{NC}$ & 4.5 & 5.2 & 3 & 34 \\
\hline 290 & Columbia & SC & 2.6 & 22.0 & 3 & 41 \\
\hline 291 & Columbia & $\mathrm{SC}$ & 2.6 & 22.0 & 3 & 41 \\
\hline 292 & Columbia & $\mathrm{SC}$ & 2.6 & 22.0 & 3 & 41 \\
\hline 293 & Spartanburg & SC & 3.4 & 14.1 & 3 & 41 \\
\hline 294 & Charleston & $\mathrm{SC}$ & 2.1 & 23.3 & 3 & 41 \\
\hline 295 & Florence & SC & 2.6 & 17.9 & 3 & 41 \\
\hline 296 & Greenville & SC & 3.2 & 14.1 & 3 & 41 \\
\hline 297 & Rock Hill & SC & 3.0 & 15.8 & 3 & 41 \\
\hline 298 & Aiken & SC & 2.4 & 20.3 & 3 & 41 \\
\hline 299 & Beaufort & SC & 1.9 & 21.5 & 3 & 41 \\
\hline 300 & Atlanta & $\mathrm{GA}$ & 3.0 & 16.8 & 3 & 11 \\
\hline 301 & Atlanta & $\mathrm{GA}$ & 3.0 & 16.8 & 3 & 11 \\
\hline 302 & Atlanta & $\mathrm{GA}$ & 3.0 & 16.8 & 3 & 11 \\
\hline 303 & Atlanta & $\mathrm{GA}$ & 3.0 & 16.8 & 3 & 11 \\
\hline 304 & Swainsboro & $\mathrm{GA}$ & 2.1 & 23.0 & 3 & 11 \\
\hline 305 & Gainesville & $\mathrm{GA}$ & 3.4 & 14.8 & 3 & 11 \\
\hline 306 & Athens & GA & 3.0 & 16.1 & 3 & 11 \\
\hline 307 & Dalton & $\mathrm{GA}$ & 3.5 & 14.7 & 3 & 11 \\
\hline 308 & Augusta & GA & 2.6 & 19.5 & 3 & 11 \\
\hline 309 & Augusta & GA & 2.6 & 19.5 & 3 & 11 \\
\hline 310 & Macon & $\mathrm{GA}$ & 2.3 & 24.4 & 3 & 11 \\
\hline 311 & Macon & $\mathrm{GA}$ & 2.3 & 24.4 & 3 & 11 \\
\hline 312 & Macon & $\mathrm{GA}$ & 2.3 & 24.4 & 3 & 11 \\
\hline 313 & Savannah & GA & 1.9 & 22.8 & 3 & 11 \\
\hline 314 & Savannah & $\mathrm{GA}$ & 1.9 & 22.8 & 3 & 11 \\
\hline 315 & Waycross & GA & 1.9 & 23.6 & 3 & 11 \\
\hline 316 & Valdosta & $\mathrm{GA}$ & 1.7 & 24.6 & 3 & 11 \\
\hline
\end{tabular}

\begin{tabular}{|c|c|c|c|c|c|c|}
\hline 317 & Albany & GA & 2.1 & 26.5 & 3 & 11 \\
\hline 318 & Columbus & $\mathrm{GA}$ & 2.4 & 22.1 & 3 & 11 \\
\hline 319 & Columbus & GA & 2.4 & 22.1 & 3 & 11 \\
\hline 320 & Jacksonville & $\mathrm{FL}$ & 1.4 & 24.2 & 3 & 10 \\
\hline 321 & Jacksonville & FL & 1.4 & 24.2 & 3 & 10 \\
\hline 322 & Jacksonville & $\mathrm{FL}$ & 1.4 & 24.2 & 3 & 10 \\
\hline 323 & Tallahassee & $\mathrm{FL}$ & 1.7 & 25.2 & 3 & 10 \\
\hline 324 & Panama City & $\mathrm{FL}$ & 1.6 & 29.0 & 3 & 10 \\
\hline 325 & Pensacola & FL & 1.6 & 29.0 & 3 & 10 \\
\hline 326 & Gainesville & $\mathrm{FL}$ & 1.1 & 27.7 & 3 & 10 \\
\hline 327 & Titusville & FL & 0.7 & 29.9 & 3 & 10 \\
\hline 328 & Orlando & FL & 0.7 & 34.0 & 3 & 10 \\
\hline 329 & Melbourne & $\mathrm{FL}$ & 0.6 & 29.7 & 3 & 10 \\
\hline 330 & Miami & $\mathrm{FL}$ & 0.2 & 39.0 & 3 & 10 \\
\hline 331 & Miami & $\mathrm{FL}$ & 0.2 & 39.0 & 3 & 10 \\
\hline 332 & Miami & FL & 0.2 & 39.0 & 3 & 10 \\
\hline 333 & $\begin{array}{c}\text { Fort } \\
\text { Lauderdale }\end{array}$ & $\mathrm{FL}$ & 0.3 & 37.1 & 3 & 10 \\
\hline 334 & $\begin{array}{l}\text { West Palm } \\
\text { Beach }\end{array}$ & $\mathrm{FL}$ & 0.3 & 35.2 & 3 & 10 \\
\hline 335 & Tampa & $\mathrm{FL}$ & 0.7 & 33.7 & 3 & 10 \\
\hline 336 & Tampa & FL & 0.7 & 33.7 & 3 & 10 \\
\hline 337 & $\begin{array}{c}\text { Saint } \\
\text { Petersburg }\end{array}$ & $\mathrm{FL}$ & 0.5 & 38.6 & 3 & 10 \\
\hline 338 & Lakeland & $\mathrm{FL}$ & 0.6 & 34.9 & 3 & 10 \\
\hline 339 & Fort Myers & $\mathrm{FL}$ & 0.4 & 37.4 & 3 & 10 \\
\hline 340 & Not used & 00 & 0.0 & 0.0 & 0 & 0 \\
\hline 341 & Not used & 00 & 0.0 & 0.0 & 0 & 0 \\
\hline 342 & Bradenton & $\mathrm{FL}$ & 0.6 & 29.2 & 3 & 10 \\
\hline 343 & Not used & 00 & 0.0 & 0.0 & 0 & 0 \\
\hline 344 & Ocala & FL & 0.9 & 32.2 & 3 & 10 \\
\hline 345 & Not used & 00 & 0.0 & 0.0 & 0 & 0 \\
\hline 346 & Clearwater & FL & 0.7 & 33.7 & 3 & 10 \\
\hline
\end{tabular}




\begin{tabular}{|c|c|c|c|c|c|c|c|c|c|c|c|c|c|}
\hline $\begin{array}{l}\text { Zip } \\
\text { Code }\end{array}$ & City & State & HDDk & CDHk & $\begin{array}{l}\text { Fuel } \\
\text { escalation } \\
\text { region }\end{array}$ & $\begin{array}{l}\text { State } \\
\text { No. }\end{array}$ & \multirow[b]{2}{*}{376} & \multirow{2}{*}{$\begin{array}{c}\text { Johnson } \\
\text { City }\end{array}$} & \multirow[b]{2}{*}{$\mathrm{TN}$} & \multirow[b]{2}{*}{3.9} & \multirow[b]{2}{*}{8.8} & \multirow[b]{2}{*}{3} & \multirow[b]{2}{*}{43} \\
\hline 347 & Orlando & $\mathrm{FL}$ & 0.7 & 34.0 & 3 & 10 & & & & & & & \\
\hline 348 & Not used & 00 & 0.0 & 0.0 & 0 & 0 & \multirow{2}{*}{377} & \multirow{2}{*}{ Knoxville } & \multirow{2}{*}{$\mathrm{TN}$} & \multirow{2}{*}{3.7} & \multirow{2}{*}{15.0} & \multirow{2}{*}{3} & \multirow{2}{*}{43} \\
\hline 349 & Fort Pierce & FI. & 05 & 304 & 3 & 10 & & & & & & & \\
\hline & & & & & & & 378 & Knoxville & $\mathrm{TN}$ & 3.7 & 15.0 & 3 & 43 \\
\hline 350 & Birmingham & $\mathrm{AL}$ & 2.9 & 21.0 & 3 & 1 & \multirow{2}{*}{379} & Knoxville & $\mathrm{TN}$ & 3.7 & 15.0 & 3 & 43 \\
\hline 351 & Birmingham & $\mathrm{AL}$ & 2.9 & 21.0 & 3 & 1 & & Memphis & & 20 & 245 & 2 & \\
\hline 352 & Birmingham & $\mathrm{AL}$ & 2.9 & 21.0 & 3 & 1 & 200 & & & 3.2 & 24.5 & 3 & 43 \\
\hline 353 & Not used & 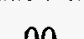 & 00 & 0 & 0 & & 381 & Memphis & $\mathrm{TN}$ & 3.2 & 24.5 & 3 & 43 \\
\hline & & & 0.0 & 0.0 & 0 & 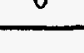 & 382 & Mc Kenzie & TN & 4.1 & 15.6 & 3 & 43 \\
\hline 354 & Tuscaloosa & $\mathrm{AL}$ & 2.7 & 24.0 & 3 & 1 & 383 & Jackson & TN & 3.6 & 18.0 & 3 & 43 \\
\hline 355 & Jasper & $\mathrm{AL}$ & 3.3 & 18.0 & 3 & 1 & 384 & Columbia & TN & 3.8 & 16.0 & 3 & 43 \\
\hline 356 & $\begin{array}{l}\text { Decatur/ } \\
\text { Florence }\end{array}$ & $\mathrm{AL}$ & 3.3 & 20.7 & 3 & 1 & 385 & Cookeville & TN & 4.5 & 7.0 & 3 & 43 \\
\hline 357 & Huntsville & $\mathrm{AL}$ & 3.3 & 18.6 & 3 & 1 & 386 & Oxford & MS & 3.6 & 19.2 & 3 & 25 \\
\hline 358 & Huntsville & $\mathrm{AL}$ & 3.3 & 18.6 & 3 & 1 & 387 & Greenville & MS & 2.6 & 25.5 & 3 & 25 \\
\hline 359 & Gadsden & $\mathrm{AL}$ & 3.2 & 17.1 & 3 & 1 & 388 & Tupelo & MS & 3.1 & 23.0 & 3 & 25 \\
\hline 360 & Montgom- & $\mathrm{AL}$ & 2.3 & 24.6 & 3 & 1 & 389 & Grenada & MS & 2.7 & 26.0 & 3 & 25 \\
\hline & & & & & & & 390 & Jackson & MS & 2.4 & 25.2 & 3 & 25 \\
\hline 361 & $\begin{array}{l}\text { Montgom- } \\
\text { ery }\end{array}$ & $\mathrm{AL}$ & 2.3 & 24.6 & 3 & 1 & 391 & Jackson & MS & 2.4 & 25.2 & 3 & 25 \\
\hline 362 & Anniston & $\mathrm{AL}$ & 2.9 & 18.2 & 3 & 1 & 392 & Jackson & MS & 2.4 & 25.2 & 3 & 25 \\
\hline 363 & Dothan & $\mathrm{AL}$ & 2.0 & 23.0 & 3 & 1 & 393 & Meridian & MS & 2.5 & 23.8 & 3 & 25 \\
\hline 364 & Evergreen & $\mathrm{AL}$ & 2.2 & 22.2 & 3 & 1 & 394 & Hattiesburg & MS & 2.0 & 24.3 & 3 & 25 \\
\hline 365 & Mobile & $\mathrm{AL}$ & 1.7 & 28.2 & 3 & 1 & 395 & Gulfport & MS & 1.5 & 27.5 & 3 & 25 \\
\hline 366 & Mobile & $\mathrm{AL}$ & 1.7 & 28.2 & 3 & 1 & 396 & McComb & MS & 2.1 & 22.8 & 3 & 25 \\
\hline 367 & Selma & $\mathrm{AL}$ & 2.0 & 26.5 & 3 & 1 & 397 & Columbus & MS & 2.9 & 21.8 & 3 & 25 \\
\hline 368 & Opelika & $\mathrm{AL}$ & 2.6 & 19.2 & 3 & 1 & 398 & Not used & 00 & 0.0 & 0.0 & 0 & 0 \\
\hline 369 & Butler & $\mathrm{AL}$ & 2.5 & 23.8 & 3 & 1 & 399 & Not used & 00 & 0.0 & 0.0 & 0 & 0 \\
\hline 370 & Nashville & $\mathrm{TN}$ & 3.8 & 18.5 & 3 & 43 & 400 & Louisville & $\mathrm{KY}$ & 4.5 & 13.3 & 3 & 18 \\
\hline 371 & Nashville & TN & 3.8 & 18.5 & 3 & 43 & 401 & Louisville & $\mathrm{KY}$ & 4.5 & 13.3 & 3 & 18 \\
\hline 372 & Nashville & $\mathrm{TN}$ & 3.8 & 18.5 & 3 & 43 & 402 & Louisville & $\mathrm{KY}$ & 4.5 & 13.3 & 3 & 18 \\
\hline 373 & Chattanooga & $\mathrm{TN}$ & 3.6 & 17.0 & 3 & 43 & 403 & Lexington & $\mathrm{KY}$ & 4.8 & 11.2 & 3 & 18 \\
\hline 374 & Chattanooga & $\mathrm{TN}$ & 3.6 & 17.0 & 3 & 43 & 404 & Lexington & $\mathrm{KY}$ & 4.8 & 11.2 & 3 & 18 \\
\hline 375 & Not used & 00 & 0.0 & 0.0 & 0 & 0 & 405 & Lexington & $\mathrm{KY}$ & 4.8 & 11.2 & 3 & 18 \\
\hline
\end{tabular}




\begin{tabular}{|c|c|c|c|c|c|c|}
\hline$\underset{\text { Code }}{\text { Zip }}$ & City & State & HDDk & CDHk & $\begin{array}{c}\text { Fuel } \\
\text { escalation } \\
\text { region }\end{array}$ & $\begin{array}{l}\text { State } \\
\text { No. }\end{array}$ \\
\hline 406 & Frankfort & KY & 5.0 & 9.7 & 3 & 18 \\
\hline 407 & Corbin & $\mathrm{KY}$ & 4.3 & 11.4 & 3 & 18 \\
\hline 408 & Baxter & $\mathrm{KY}$ & 4.7 & 7.8 & 3 & 18 \\
\hline 409 & Middlesboro & $\mathrm{KY}$ & 4.4 & 9.5 & 3 & 18 \\
\hline 410 & Newport & $\mathrm{KY}$ & 5.3 & 9.3 & 3 & 18 \\
\hline 411 & Ashland & $\mathrm{KY}$ & 4.9 & 11.4 & 3 & 18 \\
\hline 412 & Ashland & KY & 4.9 & 11.4 & 3 & 18 \\
\hline 413 & Campton & $\mathrm{KY}$ & 5.1 & 8.1 & 3 & 18 \\
\hline 414 & Campton & $\mathrm{KY}$ & 5.1 & 8.1 & 3 & 18 \\
\hline 415 & Pikeville & KY & 4.7 & 9.0 & 3 & 18 \\
\hline 416 & Pikeville & $\mathrm{KY}$ & 4.7 & 9.0 & 3 & 18 \\
\hline 417 & Hazard & $\mathrm{KY}$ & 4.7 & 9.0 & 3 & 18 \\
\hline 418 & Hazard & $\mathrm{KY}$ & 4.7 & 9.0 & 3 & 18 \\
\hline 419 & Not used & 00 & 0.0 & 0.0 & 0 & 0 \\
\hline 420 & Paducah & KY & 4.1 & 16.7 & 3 & 18 \\
\hline 421 & $\begin{array}{l}\text { Bowling } \\
\text { Green }\end{array}$ & $\mathrm{KY}$ & 4.3 & 14.7 & 3 & 18 \\
\hline 422 & Russellville & KY & 4.3 & 14.4 & 3 & 18 \\
\hline 423 & Owensboro & KY & 4.3 & 14.5 & 3 & 18 \\
\hline 424 & Henderson & $\mathrm{KY}$ & 4.3 & 14.2 & 3 & 18 \\
\hline 425 & Somerset & $\mathrm{KY}$ & 4.4 & 9.2 & 3 & 18 \\
\hline 426 & Somerset & KY & 4.4 & 9.2 & 3 & 18 \\
\hline 427 & $\begin{array}{c}\text { Elizabeth- } \\
\text { town }\end{array}$ & $\mathrm{KY}$ & 4.2 & 11.8 & 3 & 18 \\
\hline 428 & Not used & 00 & 0.0 & 0.0 & 0 & 0 \\
\hline 429 & Not used & 00 & 0.0 & 0.0 & 0 & 0 \\
\hline 430 & Columbus & $\mathrm{OH}$ & 5.7 & 7.5 & 2 & 36 \\
\hline 431 & Columbus & $\mathrm{OH}$ & 5.7 & 7.5 & 2 & 36 \\
\hline 432 & Columbus & $\mathrm{OH}$ & 5.7 & 7.5 & 2 & 36 \\
\hline 433 & Marion & $\mathrm{OH}$ & 5.9 & 6.5 & 2 & 36 \\
\hline 434 & $\begin{array}{l}\text { Bowling } \\
\text { Green - }\end{array}$ & $\mathrm{OH}$ & 6.0 & 6.6 & 2 & 36 \\
\hline 435 & Napoleon & $\mathrm{OH}$ & 6.0 & 7.1 & 2 & 36 \\
\hline
\end{tabular}

\begin{tabular}{|c|c|c|c|c|c|c|}
\hline 436 & Toledo & $\mathrm{OH}$ & 6.6 & 5.1 & 2 & 36 \\
\hline 437 & Zanesville & $\mathrm{OH}$ & 5.8 & 5.4 & 2 & 36 \\
\hline 438 & Zanesville & $\mathrm{OH}$ & 5.8 & 5.4 & 2 & 36 \\
\hline 439 & Stuebenville & $\mathrm{OH}$ & 5.6 & 5.7 & 2 & 36 \\
\hline 440 & Cleveland & $\mathrm{OH}$ & 6.2 & 4.8 & 2 & 36 \\
\hline 441 & Cleveland & $\mathrm{OH}$ & 6.2 & 4.8 & 2 & 36 \\
\hline 442 & Akron & $\mathrm{OH}$ & 6.2 & 4.8 & 2 & 36 \\
\hline 443 & Akron & $\mathrm{OH}$ & 6.2 & 4.8 & 2 & 36 \\
\hline 444 & Youngstown & $\mathrm{OH}$ & 6.6 & 3.0 & 2 & 36 \\
\hline 445 & Youngstown & $\mathrm{OH}$ & 6.6 & 3.0 & 2 & 36 \\
\hline 446 & Canton & $\mathrm{OH}$ & 6.2 & 4.8 & 2 & 36 \\
\hline 447 & Canton & $\mathrm{OH}$ & 6.2 & 4.8 & 2 & 36 \\
\hline 448 & Mansfield & $\mathrm{OH}$ & 6.3 & 4.9 & 2 & 36 \\
\hline 449 & Mansfield & $\mathrm{OH}$ & 6.3 & 4.9 & 2 & 36 \\
\hline 450 & Cincinnati & $\mathrm{OH}$ & 5.0 & 10.7 & 2 & 36 \\
\hline 451 & Cincinnati & $\mathrm{OH}$ & 5.0 & 10.7 & 2 & 36 \\
\hline 452 & Cincinnati & $\mathrm{OH}$ & 5.0 & 10.7 & 2 & 36 \\
\hline 453 & Dayton & $\mathrm{OH}$ & 5.7 & 8.3 & 2 & 36 \\
\hline 454 & Dayton & $\mathrm{OH}$ & 5.7 & 8.3 & 2 & 36 \\
\hline 455 & Springfield & $\mathrm{OH}$ & 5.7 & 8.3 & 2 & 36 \\
\hline 456 & Chillicothe & $\mathrm{OH}$ & 5.2 & 8.0 & 2 & 36 \\
\hline 457 & Athens & $\mathrm{OH}$ & 5.5 & 5.6 & 2 & 36 \\
\hline 458 & Lima & $\mathrm{OH}$ & 5.9 & 7.5 & 2 & 36 \\
\hline 459 & Not used & $\mathrm{OO}$ & 0.0 & 0.0 & 0 & 0 \\
\hline 460 & Indianapolis & $\mathrm{IN}$ & 5.7 & 9.1 & 2 & 15 \\
\hline 461 & Indianapolis & $\mathrm{IN}$ & 5.7 & 9.1 & 2 & 15 \\
\hline 462 & Indianapolis & $\mathrm{IN}$ & 5.7 & 9.1 & 2 & 15 \\
\hline 463 & Gary & $\mathrm{IN}$ & 6.3 & 9.1 & 2 & 15 \\
\hline 464 & Gary & $\mathrm{IN}$ & 6.3 & 9.1 & 2 & 15 \\
\hline 465 & South Bend & $\mathrm{IN}$ & 6.4 & 6.6 & 2 & 15 \\
\hline 466 & South Bend & $\mathrm{IN}$ & 6.4 & 6.6 & 2 & 15 \\
\hline
\end{tabular}




\begin{tabular}{|c|c|c|c|c|c|c|}
\hline $\begin{array}{l}\text { Zip } \\
\text { Code }\end{array}$ & City & State & HDDk & $\mathrm{CDHk}$ & $\begin{array}{c}\text { Fuel } \\
\text { escalation } \\
\text { region }\end{array}$ & $\begin{array}{l}\text { State } \\
\text { No. }\end{array}$ \\
\hline 467 & Fort Wayne & $\mathrm{IN}$ & 6.3 & 6.8 & 2 & 15 \\
\hline 468 & Fort Wayne & IN & 6.3 & 6.8 & 2 & 15 \\
\hline 469 & Kokomo & $\mathrm{N}$ & 6.0 & 11.1 & 2 & 15 \\
\hline 470 & $\begin{array}{l}\text { Lawrence- } \\
\text { burg }\end{array}$ & $\mathrm{N}$ & 5.3 & 10.7 & 2 & 15 \\
\hline 471 & New Albany & $\mathrm{N}$ & 4.5 & 13.3 & 2 & 15 \\
\hline 472 & Columbus & IN & 5.5 & 8.8 & 2 & 15 \\
\hline 473 & Muncie & $\mathrm{IN}$ & 6.1 & 7.1 & 2 & 15 \\
\hline 474 & $\begin{array}{l}\text { Blooming- } \\
\text { ton }\end{array}$ & $\mathrm{nN}$ & 5.3 & 10.7 & 2 & 15 \\
\hline 475 & Washington & $\mathrm{NN}$ & 4.7 & 13.3 & 2 & 15 \\
\hline 476 & Evansville & IN & 4.7 & 15.0 & 2 & 15 \\
\hline 477 & Evansville & $\mathrm{IN}$ & 4.7 & 15.0 & 2 & 15 \\
\hline 478 & Terre Haute & $\mathbb{N}$ & 5.5 & 9.5 & 2 & 15 \\
\hline 479 & Lafayette & IN & 6.2 & 7.7 & 2 & 15 \\
\hline 480 & Royal Oak & MI & 6.6 & 5.3 & 2 & 23 \\
\hline 481 & Ann Arbor & $\mathrm{MI}$ & 6.3 & 6.1 & 2 & 23 \\
\hline 482 & Detroit & $\mathrm{MI}$ & 6.6 & 4.9 & 2 & 23 \\
\hline 483 & Detroit & $\mathrm{MI}$ & 6.6 & 4.9 & 2 & 23 \\
\hline 484 & Flint & $\mathrm{MI}$ & 7.1 & 2.9 & 2 & 23 \\
\hline 485 & Flint & MI & 7.1 & 2.9 & 2 & 23 \\
\hline 486 & Saginaw & MI & 7.1 & 3.3 & 2 & 23 \\
\hline 487 & Saginaw & MI & 7.1 & 3.3 & 2 & 23 \\
\hline 488 & Lansing & MI & 7.0 & 4.1 & 2 & 23 \\
\hline 489 & Lansing & MI & 7.0 & 4.1 & 2 & 23 \\
\hline 490 & Kalamazoo & MI & 6.3 & 6.3 & 2 & 23 \\
\hline 491 & Kalamazoo & MI & 6.3 & 6.3 & 2 & 23 \\
\hline 492 & Jackson & MI & 6.8 & 4.8 & 2 & 23 \\
\hline 493 & $\begin{array}{l}\text { Grand } \\
\text { Rapids }\end{array}$ & MI & 6.9 & 4.6 & 2 & 23 \\
\hline 494 & Muskegon & MI & 6.9 & 2.9 & 2 & 23 \\
\hline 495 & $\begin{array}{l}\text { Grand } \\
\text { Rapids }\end{array}$ & MI & 6.9 & 4.6 & 2 & 23 \\
\hline
\end{tabular}

\begin{tabular}{|c|c|c|c|c|c|c|}
\hline 496 & $\begin{array}{c}\text { Traverse } \\
\text { City }\end{array}$ & MI & 7.8 & 3.0 & 2 & 23 \\
\hline 497 & $\begin{array}{l}\text { Mackinaw } \\
\text { City }\end{array}$ & $\mathrm{MI}$ & 8.0 & 2.0 & 2 & 23 \\
\hline 498 & $\begin{array}{c}\text { Iron } \\
\text { Mountain }\end{array}$ & MI & 8.7 & 1.4 & 2 & 23 \\
\hline 499 & Houghton & MI & 9.4 & 1.0 & 2 & 23 \\
\hline 500 & Des Moines & IA & 6.6 & 10.5 & 2 & 16 \\
\hline 501 & Des Moines & IA & 6.6 & 10.5 & 2 & 16 \\
\hline 502 & Des Moines & IA & 6.6 & 10.5 & 2 & 16 \\
\hline 503 & Des Moines & IA & 6.6 & 10.5 & 2 & 16 \\
\hline 504 & Mason City & IA & 7.9 & 6.0 & 2 & 16 \\
\hline 505 & Fort Dodge & IA & 7.2 & 8.0 & 2 & 16 \\
\hline 506 & Waterloo & IA & 7.5 & 6.6 & 2 & 16 \\
\hline 507 & Waterloo & IA & 7.5 & 6.6 & 2 & 16 \\
\hline 508 & Creston & IA & 6.5 & 9.5 & 2 & 16 \\
\hline 509 & Not used & 00 & 0.0 & 0.0 & 0 & 0 \\
\hline 510 & Sioux City & IA & 7.0 & 10.1 & 2 & 16 \\
\hline 511 & Sioux City & IA & 7.0 & 10.1 & 2 & 16 \\
\hline 512 & Sheldon & IA & 7.7 & 6.6 & 2 & 16 \\
\hline 513 & Spencer & IA & 7.8 & 6.1 & 2 & 16 \\
\hline 514 & Carroll & IA & 7.1 & 8.2 & 2 & 16 \\
\hline 515 & $\begin{array}{l}\text { Council } \\
\text { Bluffs }\end{array}$ & IA & 6.2 & 12.0 & 2 & 16 \\
\hline 516 & Shenandoah & IA & 5.9 & 12.7 & 2 & 16 \\
\hline 517 & Not used & 00 & 0.0 & 0.0 & 0 & 0 \\
\hline 518 & Not used & 00 & 0.0 & 0.0 & 0 & 0 \\
\hline 519 & not used & 00 & 0.0 & 0.0 & 0 & 0 \\
\hline 520 & Dubuque & IA & 7.4 & 4.7 & 2 & 16 \\
\hline 521 & Decorah & IA & 7.6 & 5.3 & 2 & 16 \\
\hline 522 & $\begin{array}{l}\text { Cedar } \\
\text { Rapids }\end{array}$ & IA & 6.7 & 7.9 & 2 & 16 \\
\hline 523 & $\begin{array}{l}\text { Cedar } \\
\text { Rapids }\end{array}$ & IA & 6.7 & 7.9 & 2 & 16 \\
\hline
\end{tabular}




\begin{tabular}{|c|c|c|c|c|c|c|}
\hline $\begin{array}{l}\text { Zip } \\
\text { Code }\end{array}$ & City & State & HDDk & $\mathrm{CDHK}$ & $\begin{array}{c}\text { Fuel } \\
\text { escalation } \\
\text { region }\end{array}$ & $\begin{array}{l}\text { State } \\
\text { No. }\end{array}$ \\
\hline 524 & $\begin{array}{l}\text { Cedar } \\
\text { Rapids }\end{array}$ & IA & 6.7 & 7.9 & 2 & 16 \\
\hline 525 & Ottumwa & IA & 6.3 & 10.0 & 2 & 16 \\
\hline 526 & Burlington & IA & 6.2 & 10.0 & 2 & 16 \\
\hline 527 & Davenport & IA & 6.3 & 10.0 & 2 & 16 \\
\hline 528 & Davenport & IA & 6.3 & 10.0 & 2 & 16 \\
\hline 529 & Not used & 00 & 0.0 & 0.0 & 0 & 0 \\
\hline 530 & Milwaukee & WI & 7.3 & 3.3 & 2 & 50 \\
\hline 531 & Milwaukee & WI & 7.3 & 3.3 & 2 & 50 \\
\hline 532 & Milwaukee & WI & 7.3 & 3.3 & 2 & 50 \\
\hline 533 & Milwaukee & WI & 7.3 & 3.3 & 2 & 50 \\
\hline 534 & Racine & WI & 6.9 & 5.2 & 2 & 50 \\
\hline 535 & Madison & WI & 7.6 & 3.3 & 2 & 50 \\
\hline 536 & Madison & WI & 7.6 & 3.3 & 2 & 50 \\
\hline 537 & Madison & WI & 7.6 & 3.3 & 2 & 50 \\
\hline 538 & Platteville & WI & 7.2 & 5.6 & 2 & 50 \\
\hline 539 & Portage & WI & 7.4 & 5.5 & 2 & 50 \\
\hline 540 & River Falls & WI & 8.1 & 4.6 & 2 & 50 \\
\hline 541 & Green Bay & WI & 8.1 & 2.5 & 2 & 50 \\
\hline 542 & Green Bay & WI & 8.1 & 2.5 & 2 & 50 \\
\hline 543 & Green Bay & WI & 8.1 & 2.5 & 2 & 50 \\
\hline 544 & Wausau & WI & 8.6 & 2.5 & 2 & 50 \\
\hline 545 & Rhinelander & WI & 8.9 & 2.3 & 2 & 50 \\
\hline 546 & La Crosse & WI & 7.5 & 6.8 & 2 & 50 \\
\hline 547 & Eau Claire & WI & 8.5 & 3.9 & 2 & 50 \\
\hline 548 & Spooner & WI & 8.8 & 2.5 & 2 & 50 \\
\hline 549 & Oshkosh & WI & 7.7 & 3.7 & 2 & 50 \\
\hline 550 & Saint Paul & $\mathrm{MN}$ & 8.0 & 6.8 & 2 & 24 \\
\hline 551 & Saint Paul & $\mathrm{MN}$ & 8.0 & 6.8 & 2 & 24 \\
\hline 552 & Not used & 00 & 0.0 & 0.0 & 0 & 0 \\
\hline 553 & Minneapolis & $\mathrm{MN}$ & 8.0 & 6.8 & 2 & 24 \\
\hline
\end{tabular}

\begin{tabular}{|c|c|c|c|c|c|c|}
\hline 554 & Minneapolis & $\mathrm{MN}$ & 8.0 & 6.8 & 2 & 24 \\
\hline 555 & Not used & 00 & 0.0 & 0.0 & 0 & 0 \\
\hline 556 & Duluth & $\mathrm{MN}$ & 9.9 & $0: 8$ & 2 & 24 \\
\hline 557 & Duluth & $\mathrm{MN}$ & 9.9 & 0.8 & 2 & 24 \\
\hline 558 & Duluth & $\mathrm{MN}$ & 9.9 & 0.8 & 2 & 24 \\
\hline 559 & Rochester & $\mathrm{MN}$ & 8.3 & 3.9 & 2 & 24 \\
\hline 560 & Mankato & $\mathrm{MN}$ & 8.3 & 5.0 & 2 & 24 \\
\hline 561 & Windom & $\mathrm{MN}$ & 7.8 & 7.2 & 2 & 24 \\
\hline 562 & Willmar & $\mathrm{MN}$ & 8.3 & 4.7 & 2 & 24 \\
\hline 563 & Saint Cloud & $\mathrm{MN}$ & 9.0 & 3.0 & 2 & 24 \\
\hline 564 & Brainerd & $\mathrm{MN}$ & 9.0 & 3.5 & 2 & 24 \\
\hline 565 & $\begin{array}{l}\text { Detroit } \\
\text { Lakes }\end{array}$ & $\mathrm{MN}$ & 9.9 & 2.3 & 2 & 24 \\
\hline 566 & Bemidji & $\mathrm{MN}$ & 10.2 & 2.2 & 2 & 24 \\
\hline 567 & $\begin{array}{l}\text { Thief River } \\
\text { Falls }\end{array}$ & $\mathrm{MN}$ & 9.7 & 3.0 & 2 & 24 \\
\hline 568 & Not used & 00 & 0.0 & 0.0 & 0 & 0 \\
\hline 569 & Not used & 00 & 0.0 & 0.0 & 0 & 0 \\
\hline 570 & Sioux Falls & $\mathrm{SD}$ & 7.9 & 8.6 & 2 & 42 \\
\hline 571 & Sioux Falls & $S D$ & 7.9 & 8.6 & 2 & 42 \\
\hline 572 & Watertown & $\mathrm{SD}$ & 8.8 & 4.9 & 2 & 42 \\
\hline 573 & Mitchell & SD & 7.4 & 10.3 & 2 & 42 \\
\hline 574 & Aberdeen & $\mathrm{SD}$ & 8.6 & 6.5 & 2 & 42 \\
\hline 575 & Pierre & $S D$ & 7.6 & 10.4 & 2 & 42 \\
\hline 576 & Mobridge & SD & 8.2 & 7.8 & 2 & 42 \\
\hline 577 & Rapid City & SD & 7.3 & 8.2 & 2 & 42 \\
\hline 578 & Not used & 00 & 0.0 & 0.0 & 0 & 0 \\
\hline 579 & Not used & 00 & 0.0 & 0.0 & 0 & 0 \\
\hline 580 & Fargo & ND & 9.3 & 4.3 & 2 & 35 \\
\hline 581 & Fargo & $\mathrm{ND}$ & 9.3 & 4.3 & 2 & 35 \\
\hline 582 & Grand Forks & ND & 9.9 & 4.1 & 2 & 35 \\
\hline 583 & Devils Lake & ND & 9.9 & 3.1 & 2 & 35 \\
\hline
\end{tabular}




\begin{tabular}{|c|c|c|c|c|c|c|}
\hline $\begin{array}{c}\text { Zip } \\
\text { Code }\end{array}$ & City & State & HDDk & CDHk & $\begin{array}{l}\text { Fuel } \\
\text { escalation } \\
\text { region }\end{array}$ & $\begin{array}{l}\text { State } \\
\text { No. }\end{array}$ \\
\hline 584 & Jamestown & ND & 9.4 & 4.0 & 2 & 35 \\
\hline 585 & Bismarck & $\mathrm{ND}$ & 9.1 & 4.6 & 2 & 35 \\
\hline 586 & Dickinson & $\mathrm{ND}$ & 8.9 & 4.0 & 2 & 35 \\
\hline 587 & Minot & ND & 9.4 & 4.0 & 2 & 35 \\
\hline 588 & Williston & $\mathrm{ND}$ & 9.3 & 4.0 & 2 & 35 \\
\hline 589 & Not used & 00 & 0.0 & 0.0 & 0 & 0 \\
\hline 590 & Billings & $\mathrm{MT}$ & 7.2 & 6.0 & 4 & 27 \\
\hline 591 & Billings & $\mathrm{MT}$ & 7.2 & 6.0 & 4 & 27 \\
\hline 592 & Wolf Point & MT & 9.0 & 4.8 & 4 & 27 \\
\hline 593 & Miles City & $\mathrm{MT}$ & 7.9 & 10.0 & 4 & 27 \\
\hline 594 & Great Falls & $\mathrm{MT}$ & 7.8 & 3.6 & 4 & 27 \\
\hline 595 & Havre & MT & 8.7 & 4.0 & 4 & 27 \\
\hline 596 & Helena & $\mathrm{MT}$ & 8.2 & 2.5 & 4 & 27 \\
\hline 597 & Butte & MT & 9.6 & 0.9 & 4 & 27 \\
\hline 598 & Missoula & $\mathrm{MT}$ & 7.8 & 1.1 & 4 & 27 \\
\hline $599^{\circ}$ & Kalispell & $\mathrm{MT}$ & 8.4 & 1.7 & 4 & 27 \\
\hline 600 & $\begin{array}{c}\text { North } \\
\text { Chicago } \\
\text { Sub. }\end{array}$ & IL & 6.9 & 5.2 & 2 & 14 \\
\hline 601 & $\begin{array}{c}\text { North } \\
\text { Chicago } \\
\text { Sub. }\end{array}$ & IL & 6.9 & 5.2 & 2 & 14 \\
\hline 602 & Evanston & IL & 6.5 & 6.6 & 2 & 14 \\
\hline 603 & Oak Park & IL & 6.5 & 6.6 & 2 & 14 \\
\hline 604 & $\begin{array}{l}\text { South } \\
\text { Chicago } \\
\text { Sub. }\end{array}$ & IL & 6.5 & 7.4 & 2 & 14 \\
\hline 605 & $\begin{array}{c}\text { South } \\
\text { Chicago } \\
\text { Sub. }\end{array}$ & IL & 6.2 & 7.4 & 2 & 14 \\
\hline 606 & Chicago & IL & 6.2 & 9.7 & 2 & 14 \\
\hline 607 & Chicago & IL & 6.2 & 9.7 & 2 & 14 \\
\hline 608 & Not used & 00 & 0.0 & 0.0 & 0 & 0 \\
\hline 609 & Kankakee & IL & 6.1 & 8.8 & 2 & 14 \\
\hline 610 & Rockford & IL & 7.0 & 6.5 & 2 & 14 \\
\hline
\end{tabular}

\begin{tabular}{|c|c|c|c|c|c|c|}
\hline 611 & Rockford & IL & 7.0 & 6.5 & 2 & 14 \\
\hline 612 & Rock Island & IL & 6.3 & 10.0 & 2 & 14 \\
\hline 613 & La Salle & $\mathrm{IL}$ & 6.2 & 11.1 & 2 & 14 \\
\hline 614 & Galesburg & IL & 6.3 & 8.9 & 2 & 14 \\
\hline 615 & Peoria & IL & 6.2 & 9.5 & 2 & 14 \\
\hline 616 & Peoria & IL & 6.2 & 9.5 & 2 & 14 \\
\hline 617 & $\begin{array}{l}\text { Blooming- } \\
\text { ton }\end{array}$ & IL & 5.9 & 9.4 & 2 & 14 \\
\hline 618 & $\begin{array}{c}\text { Champaign/ } \\
\text { Urbana }\end{array}$ & IL & 5.8 & 9.9 & 2 & 14 \\
\hline 619 & $\begin{array}{c}\text { Champaign/ } \\
\text { Urbana }\end{array}$ & IL & 5.8 & 9.9 & 2 & 14 \\
\hline 620 & $\begin{array}{l}\text { East Saint } \\
\text { Louis }\end{array}$ & IL & 4.8 & 14.7 & 2 & 14 \\
\hline 621 & Not used & 00 & 0.0 & 0.0 & 0 & 0 \\
\hline 622 & $\begin{array}{l}\text { East Saint } \\
\text { Louis }\end{array}$ & IL & 4.8 & 14.7 & 2 & 14 \\
\hline 623 & Quincy & IL & 5.8 & 12.2 & 2 & 14 \\
\hline 624 & Effingham & $\mathrm{IL}$ & 5.3 & 13.2 & 2 & 14 \\
\hline 625 & Springfield & IL & 5.7 & 12.4 & 2 & 14 \\
\hline 626 & Springfield & IL & 5.7 & 12.4 & 2 & 14 \\
\hline 627 & Springfield & $\mathrm{IL}$ & 5.7 & 12.4 & 2 & 14 \\
\hline 628 & Centralia & IL & 4.8 & 13.5 & 2 & 14 \\
\hline 629 & Carbondale & IL & 4.6 & 14.1 & 2 & 14 \\
\hline 630 & Saint Louis & MO & 4.9 & 17.8 & 2 & 26 \\
\hline 631 & Saint Louis & MO & 4.9 & 17.8 & 2 & 26 \\
\hline 632 & Not used & 00 & 0.0 & 0.0 & 0 & 0 \\
\hline 633 & $\begin{array}{c}\text { Saint } \\
\text { Charles }\end{array}$ & MO & 5.0 & 17.1 & 2 & 26 \\
\hline 634 & Hannibal & $\mathrm{MO}$ & 5.6 & 11.8 & 2 & 26 \\
\hline 635 & Kirksville & $\mathrm{MO}$ & 5.9 & 9.9 & 2 & 26 \\
\hline 636 & Flat River & MO & 4.8 & 12.2 & 2 & 26 \\
\hline 637 & $\begin{array}{c}\text { Cape } \\
\text { Girardeau }\end{array}$ & MO & 4.3 & 16.8 & 2 & 26 \\
\hline 638 & Sikeston & MO & 4.2 & 16.9 & 2 & 26 \\
\hline
\end{tabular}




\begin{tabular}{|c|c|c|c|c|c|c|}
\hline $\begin{array}{l}\text { Zip } \\
\text { Code }\end{array}$ & City & State & HDDk & $\mathrm{CDHk}$ & $\begin{array}{c}\text { Fuel } \\
\text { escalation } \\
\text { region }\end{array}$ & $\begin{array}{l}\text { State } \\
\text { No. }\end{array}$ \\
\hline 639 & Poplar Bluff & MO & 4.1 & 17.2 & 2 & 26 \\
\hline 640 & Kansas City & MO & 5.3 & 17.5 & 2 & 26 \\
\hline 641 & Kansas City & MO & 5.3 & 17.5 & 2 & 26 \\
\hline 642 & Not used & 00 & 0.0 & 0.0 & 0 & 0 \\
\hline 643 & not used & 00 & 0.0 & 0.0 & 0 & 0 \\
\hline 644 & Saint Joseph & MO & 5.5 & 16.1 & 2 & 26 \\
\hline 645 & Saint Joseph & MO & 5.5 & 16.1 & 2 & 26 \\
\hline 646 & Chillicothe & MO & 5.4 & 14.4 & 2 & 26 \\
\hline 647 & $\begin{array}{l}\text { Harrison- } \\
\text { ville }\end{array}$ & MO & 4.9 & 17.4 & 2 & 26 \\
\hline 648 & Joplin & MO & 4.3 & 20.8 & 2 & 26 \\
\hline 649 & Not used & 00 & 0.0 & 0.0 & 0 & 0 \\
\hline 650 & $\begin{array}{l}\text { Jefferson } \\
\text { City }\end{array}$ & MO & 4.9 & 15.0 & 2 & 26 \\
\hline 651 & $\begin{array}{l}\text { Jefferson } \\
\text { City }\end{array}$ & MO & 4.9 & 15.0 & 2 & 26 \\
\hline 652 & Columbia & MO & 5.2 & 14.5 & 2 & 26 \\
\hline 653 & Sedalia & MO & 5.0 & 17.2 & 2 & 26 \\
\hline 654 & Rolla & MO & 4.8 & 12.8 & 2 & 26 \\
\hline 655 & Rolla & MO & 4.8 & 12.8 & 2 & 26 \\
\hline 656 & Springfield & MO & 4.7 & 16.3 & 2 & 26 \\
\hline 657 & Springfield & MO & 4.7 & 16.3 & 2 & 26 \\
\hline 658 & Springfield & MO & 4.7 & 16.3 & 2 & 26 \\
\hline 659 & Not used & 00 & 0.0 & 0.0 & 0 & 0 \\
\hline 660 & Kansas City & KS & 5.3 & 17.5 & 2 & 17 \\
\hline 661 & Kansas City & KS & 5.3 & 17.5 & 2 & 17 \\
\hline 662 & $\begin{array}{l}\text { Shawnee/ } \\
\text { Mission }\end{array}$ & $\mathrm{KS}$ & 5.3 & 17.5 & 2 & 17 \\
\hline 663 & Not used & 00 & 0.0 & 0.0 & 0 & 0 \\
\hline 664 & Topeka & KS & 5.3 & 16.6 & 2 & 17 \\
\hline 665 & Topeka & KS & 5.3 & 16.6 & 2 & 17 \\
\hline 666 & Topeka & KS & 5.3 & 16.6 & 2 & 17 \\
\hline 667 & Fort Scott & $\mathrm{KS}$ & 4.3 & 24.1 & 2 & 17 \\
\hline
\end{tabular}

\begin{tabular}{|c|c|c|c|c|c|c|}
\hline 668 & Emporia & $\mathrm{KS}$ & 5.1 & 17.4 & 2 & 17 \\
\hline 669 & Concordia & $\mathrm{KS}$ & 5.6 & 16.7 & 2 & 17 \\
\hline 670 & Wichita & $\mathrm{KS}$ & 4.8 & 21.2 & 2 & 17 \\
\hline 671 & Wichita & $\mathrm{KS}$ & 4.8 & 21.2 & 2 & 17 \\
\hline 672 & Wichita & $\mathrm{KS}$ & 4.8 & 21.2 & 2 & 17 \\
\hline 673 & Indepen- & $\mathrm{KS}$ & 4.3 & 20.3 & 2 & 17 \\
\hline 674 & Salina & $\mathrm{KS}$ & 5.2 & 19.8 & 2 & 17 \\
\hline 675 & Hutchinson & $\mathrm{KS}$ & 4.6 & 21.9 & 2 & 17 \\
\hline 676 & Hays & $\mathrm{KS}$ & 5.7 & 16.3 & 2 & 17 \\
\hline 677 & Colby & $\mathrm{KS}$ & 6.2 & 11.9 & 2 & 17 \\
\hline 678 & Dodge City & $\mathrm{KS}$ & 5.1 & 18.5 & 2 & 17 \\
\hline 679 & Liberal & $\mathrm{KS}$ & 4.3 & 18.5 & 2 & 17 \\
\hline 680 & Omaha & $\mathrm{NE}$ & 6.2 & 12.0 & 2 & 28 \\
\hline 681 & Omaha & $\mathrm{NE}$ & 6.2 & 12.0 & 2 & 28 \\
\hline 682 & Not used & 00 & 0.0 & 0.0 & 0 & 0 \\
\hline 683 & Lincoln & $\mathrm{NE}$ & 6.4 & 13.6 & 2 & 28 \\
\hline 684 & Lincoln & $\mathrm{NE}$ & 6.4 & 13.6 & 2 & 28 \\
\hline 685 & Lincoln & $\mathrm{NE}$ & 6.4 & 13.6 & 2 & 28 \\
\hline 686 & Columbus & $\mathrm{NE}$ & 6.5 & 12.7 & 2 & 28 \\
\hline 687 & Norfolk & $\mathrm{NE}$ & 7.0 & 10.6 & 2 & 28 \\
\hline 688 & Grand & $\mathrm{NE}$ & 6.5 & 12.0 & 2 & 28 \\
\hline 689 & Hastings & $\mathrm{NE}$ & 6.1 & 12.6 & 2 & 28 \\
\hline 690 & McCook & $\mathrm{NE}$ & 5.8 & 13.6 & 2 & 28 \\
\hline 691 & North Platte & $\mathrm{NE}$ & 6.9 & 8.5 & 2 & 28 \\
\hline 692 & Valentine & $\mathrm{NE}$ & 7.4 & 8.2 & 2 & 28 \\
\hline 693 & Alliance & $\mathrm{NE}$ & 7.1 & 6.4 & 2 & 28 \\
\hline 694 & Not used & 00 & 0.0 & 0.0 & 0 & 0 \\
\hline 695 & Not used & 00 & 0.0 & 0.0 & 0 & 0 \\
\hline 696 & Not used & 00 & 0.0 & 0.0 & 0 & 0 \\
\hline 697 & Not used & 00 & 0.0 & 0.0 & 0 & 0 \\
\hline
\end{tabular}




\begin{tabular}{|c|c|c|c|c|c|c|}
\hline$\underset{\text { Code }}{\text { Zip }}$ & City & State & HDDk & CDHk & $\begin{array}{c}\text { Fuel } \\
\text { escalation } \\
\text { region }\end{array}$ & $\begin{array}{l}\text { State } \\
\text { No. }\end{array}$ \\
\hline 698 & Not used & 00 & 0.0 & 0.0 & 0 & 0 \\
\hline 699 & Not used & 00 & 0.0 & 0.0 & 0 & 0 \\
\hline 700 & $\begin{array}{c}\text { New } \\
\text { Orleans }\end{array}$ & LA & 1.5 & 28.6 & 3 & 19 \\
\hline 701 & $\begin{array}{l}\text { New } \\
\text { Orleans }\end{array}$ & LA & 1.5 & 28.6 & 3 & 19 \\
\hline 702 & Not used & 00 & 0.0 & 0.0 & 0 & 0 \\
\hline 703 & Thibodaux & $\mathrm{LA}$ & 1.3 & 27.9 & 3 & 19 \\
\hline 704 & Hammond & LA & 1.7 & 24.7 & 3 & 19 \\
\hline 705 & Lafayette & LA & 1.6 & 28.5 & 3 & 19 \\
\hline 706 & $\begin{array}{l}\text { Lake } \\
\text { Charles }\end{array}$ & LA & 1.6 & 28.6 & 3 & 19 \\
\hline 707 & $\begin{array}{l}\text { Baton } \\
\text { Rouge }\end{array}$ & LA & 1.7 & 26.9 & 3 & 19 \\
\hline 708 & $\begin{array}{l}\text { Baton } \\
\text { Rouge }\end{array}$ & LA & 1.7 & 26.9 & 3 & 19 \\
\hline 709 & Not used & 00 & 0.0 & 0.0 & 0 & 0 \\
\hline 710 & Shreveport & LA & 2.3 & 28.3 & 3 & 19 \\
\hline 711 & Shreveport & LA & 2.3 & 28.3 & 3 & 19 \\
\hline 712 & Monroe & LA & 2.4 & 26.6 & 3 & 19 \\
\hline 713 & Alexandria & LA & 2.0 & 27.3 & 3 & 19 \\
\hline 714 & Alexandria & LA & 2.0 & 27.3 & 3 & 19 \\
\hline 715 & Not used & 00 & 0.0 & 0.0 & 0 & 0 \\
\hline 716 & Pine Bluff & $\mathrm{AR}$ & 2.7 & 26.7 & 3 & 4 \\
\hline 717 & Camden & $\mathrm{AR}$ & 2.8 & 23.7 & 3 & 4 \\
\hline 718 & Hope & AR & 3.0 & 22.5 & 3 & 4 \\
\hline 719 & $\begin{array}{l}\text { Hot Springs } \\
\text { Nat Pk }\end{array}$ & AR & 2.9 & 26.6 & 3 & 4 \\
\hline 720 & Little Rock & $\mathrm{AR}$ & 3.2 & 23.8 & 3 & 4 \\
\hline 721 & Little Rock & AR & 3.2 & 23.8 & 3 & 4 \\
\hline 722 & Little Rock & AR & 3.2 & 23.8 & 3 & 4 \\
\hline 723 & $\begin{array}{c}\text { West } \\
\text { Memphis }\end{array}$ & $\mathrm{AR}$ & 3.2 & 24.5 & 3 & 4 \\
\hline 724 & Jonesboro & $\mathrm{AR}$ & 3.6 & 23.2 & 3 & 4 \\
\hline 725 & Batesville & AR & 3.7 & 19.0 & 3 & 4 \\
\hline
\end{tabular}

\begin{tabular}{|c|c|c|c|c|c|c|}
\hline 726 & Harrison & AR & 3.9 & 18.5 & 3 & 4 \\
\hline 727 & Fayetteville & AR & 4.2 & 16.0 & 3 & 4 \\
\hline 728 & Russellville & AR & 3.4 & 22.7 & 3 & 4 \\
\hline 729 & Fort Smith & AR & 3.5 & 23.5 & 3 & 4 \\
\hline 730 & Oklahoma & OK & 3.7 & 23.0 & 3 & 37 \\
\hline 731 & Okity & & & & & \\
\hline 732 & Not used & OK & 3.7 & 23.0 & 3 & 37 \\
\hline 733 & Not used & O0 & 0.0 & 0.0 & 0 & 0 \\
\hline 734 & Ardmore & OK & 2.6 & 31.7 & 3 & 37 \\
\hline 735 & Lawton & OK & 3.2 & 27.1 & 3 & 37 \\
\hline 736 & Clinton & OK & 3.7 & 26.4 & 3 & 37 \\
\hline 737 & Enid & OK & 3.8 & 26.1 & 3 & 37 \\
\hline 738 & Woodward & OK & 4.4 & 23.2 & 3 & 37 \\
\hline 739 & Guymon & OK & 4.5 & 17.5 & 3 & 37 \\
\hline 740 & Tulsa & OK & 3.7 & 26.5 & 3 & 37 \\
\hline 741 & Tulsa & OK & 3.7 & 26.5 & 3 & 37 \\
\hline 742 & Not used & O0 & 0.0 & 0.0 & 0 & 0 \\
\hline 743 & Vinita & OK & 3.9 & 23.2 & 3 & 37 \\
\hline 744 & Muskogee & OK & 3.4 & 25.7 & 3 & 37 \\
\hline 745 & McAlester & OK & 3.4 & 26.3 & 3 & 37 \\
\hline 746 & Ponca City & OK & 4.3 & 24.3 & 3 & 37 \\
\hline 747 & Durant & OK & 2.7 & 26.1 & 3 & 37 \\
\hline 748 & Shawnee & OK & 3.1 & 27.4 & 3 & 37 \\
\hline 749 & Poteau & OK & 3.1 & 25.3 & 3 & 37 \\
\hline 750 & Dallas & TX & 2.3 & 36.7 & 3 & 44 \\
\hline 751 & Dallas & TX & 2.3 & 36.7 & 3 & 44 \\
\hline 752 & Dallas & TX & 2.3 & 36.7 & 3 & 44 \\
\hline 753 & Dallas & TX & 2.5 & 36.7 & 3 & 44 \\
\hline 754 & Greenville & TX & 2.3 & 27.7 & 3 & 44 \\
\hline 755 & Texarkana & TX & 2.6 & 23.0 & 3 & 44 \\
\hline
\end{tabular}




\begin{tabular}{|c|c|c|c|c|c|c|}
\hline $\begin{array}{c}\text { Zip } \\
\text { Code }\end{array}$ & City & State & HDDk & CDHK & $\begin{array}{c}\text { Fuel } \\
\text { escalation } \\
\text { region }\end{array}$ & $\begin{array}{c}\text { State } \\
\text { No. }\end{array}$ \\
\hline 756 & Longview & $\mathrm{TX}$ & 2.5 & 28.7 & 3 & 44 \\
\hline 757 & Tyler & $\mathrm{TX}$ & 2.3 & 24.9 & 3 & 44 \\
\hline 758 & Palestine & $\mathrm{TX}$ & 2.3 & 28.5 & 3 & 44 \\
\hline 759 & Lufkin & TX & 1.9 & 30.4 & 3 & 44 \\
\hline 760 & Fort Worth & $\mathrm{TX}$ & 2.4 & 36.3 & 3 & 44 \\
\hline 761 & Fort Worth & TX & 2.4 & 36.3 & 3 & 44 \\
\hline 762 & Denton & $\mathrm{TX}$ & 2.5 & 31.5 & 3 & 44 \\
\hline 763 & $\begin{array}{l}\text { Wichita } \\
\text { Falls }\end{array}$ & TX & 3.0 & 34.5 & 3 & 44 \\
\hline 764 & Stephenville & $\mathrm{TX}$ & 2.7 & 27.4 & 3 & 44 \\
\hline 765 & Temple & $\mathrm{TX}$ & 2.1 & 33.1 & 3 & 44 \\
\hline 766 & Waco & $\mathrm{TX}$ & 2.1 & 36.7 & 3 & 44 \\
\hline 767 & Waco & $\mathrm{TX}$ & 2.1 & 36.7 & 3 & 44 \\
\hline 768 & Brownwood & $\mathrm{TX}$ & 2.5 & 32.4 & 3 & 44 \\
\hline 769 & San Angelo & TX & 2.3 & 32.7 & 3 & 44 \\
\hline 770 & Houston & TX & 1.5 & 30.5 & 3 & 44 \\
\hline 771 & Houston & $\mathrm{TX}$ & 1.5 & 30.5 & 3 & 44 \\
\hline 772 & Houston & TX & 1.5 & 30.5 & 3 & 44 \\
\hline 773 & Conroe & $\mathrm{TX}$ & 1.8 & 30.5 & 3 & 44 \\
\hline 774 & Houston & TX & 1.5 & 30.5 & 3 & 44 \\
\hline 775 & Galveston & $\mathrm{TX}$ & 1.3 & 31.9 & 3 & 44 \\
\hline 776 & Beaumont & $\mathrm{TX}$ & 1.5 & 31.7 & 3 & 44 \\
\hline 777 & Beaumont & $\mathrm{TX}$ & 1.5 & 31.7 & 3 & 44 \\
\hline 778 & Bryan & $\mathrm{TX}$ & 1.7 & 34.2 & 3 & 44 \\
\hline 779 & Victoria & TX & 1.3 & 37.3 & 3 & 44 \\
\hline 780 & $\begin{array}{l}\text { Laredo/ } \\
\text { Pearsall }\end{array}$ & $\mathrm{TX}$ & 1.3 & 52.6 & 3 & 44 \\
\hline 781 & San Antonio & $\mathrm{TX}$ & 1.6 & 36.2 & 3 & 44 \\
\hline 782 & San Antonio & TX & 1.6 & 36.2 & 3 & 44 \\
\hline 783 & $\begin{array}{l}\text { Corpus } \\
\text { Christi }\end{array}$ & $\mathrm{TX}$ & 1.0 & 42.0 & 3 & 44 \\
\hline 784 & $\begin{array}{l}\text { Corpus } \\
\text { Christi }\end{array}$ & TX & 1.0 & 42.0 & 3 & 44 \\
\hline
\end{tabular}

\begin{tabular}{|c|c|c|c|c|c|c|}
\hline 785 & Brownsville & TX & 0.6 & 42.5 & 3 & 44 \\
\hline 786 & Austin & $\mathrm{TX}$ & 1.8 & 35.2 & 3 & 44 \\
\hline 787 & Austin & $T X$ & 1.8 & 35.2 & 3 & 44 \\
\hline 788 & Uvalde & $\mathrm{TX}$ & 1.6 & 37.1 & 3 & 44 \\
\hline 789 & Giddings & $\mathrm{TX}$ & 1.7 & 34.2 & 3 & 44 \\
\hline 790 & Amarillo & $\mathrm{TX}$ & 4.2 & 15.7 & 3 & 44 \\
\hline 791 & Amarillo & $\mathrm{TX}$ & 4.2 & 15.7 & 3 & 44 \\
\hline 792 & Childress & TX & 3.3 & 27.1 & 3 & 44 \\
\hline 793 & Lubbock & TX & 3.5 & 18.2 & 3 & 44 \\
\hline 794 & Lubbock & TX & 3.5 & 18.2 & 3 & 44 \\
\hline 795 & Abilene & TX & 2.6 & 31.9 & 3 & 44 \\
\hline 796 & Abilene & TX & 2.6 & 31.9 & 3 & 44 \\
\hline 797 & Midland & TX & 2.6 & 25.0 & 3 & 44 \\
\hline 798 & El Paso & $\mathrm{TX}$ & 2.7 & 23.0 & 3 & 44 \\
\hline 799 & El Paso & $\mathrm{TX}$ & 2.7 & 23.0 & 3 & 44 \\
\hline 800 & Denver & $\mathrm{CO}$ & 6.0 & 5.9 & 4 & 6 \\
\hline 801 & Denver & $\mathrm{CO}$ & 6.0 & 5.9 & 4 & 6 \\
\hline 802 & Denver & $\mathrm{CO}$ & 6.0 & 5.9 & 4 & 6 \\
\hline 803 & Boulder & $\mathrm{CO}$ & 5.5 & 7.7 & 4 & 6 \\
\hline 804 & $\begin{array}{l}\text { Golden/ } \\
\text { Dillon }\end{array}$ & $\mathrm{CO}$ & 10.0 & 0.0 & 4 & 6 \\
\hline 805 & Longmont & $\mathrm{CO}$ & 6.4 & 3.8 & 4 & 6 \\
\hline 806 & Greeley & $\mathrm{CO}$ & 6.5 & 5.1 & 4 & 6 \\
\hline 807 & Fort Morgan & $\mathrm{CO}$ & 6.5 & 7.2 & 4 & 6 \\
\hline 808 & $\begin{array}{l}\text { Colorado } \\
\text { Springs }\end{array}$ & $\mathrm{CO}$ & 6.4 & 3.7 & 4 & 6 \\
\hline 809 & $\begin{array}{c}\text { Colorado } \\
\text { Springs }\end{array}$ & $\mathrm{CO}$ & 6.4 & 3.7 & 4 & 6 \\
\hline 810 & Pueblo & $\mathrm{CO}$ & 5.5 & 11.0 & 4 & 6 \\
\hline 811 & Alamosa & $\mathrm{CO}$ & 8.7 & 0.0 & 4 & 6 \\
\hline 812 & Salida & $\mathrm{CO}$ & 9.0 & 0.0 & 4 & 6 \\
\hline 813 & Durango & $\mathrm{CO}$ & 6.8 & 0.4 & 4 & 6 \\
\hline 814 & Montrose & $\mathrm{CO}$ & 6.4 & 3.6 & 4 & 6 \\
\hline
\end{tabular}




\begin{tabular}{|c|c|c|c|c|c|c|}
\hline $\begin{array}{l}\text { Zip } \\
\text { Code }\end{array}$ & City & State & HDDk & CDHk & $\begin{array}{c}\text { Fuel } \\
\text { escalation } \\
\text { region }\end{array}$ & $\begin{array}{l}\text { State } \\
\text { No. }\end{array}$ \\
\hline 815 & $\begin{array}{l}\text { Grand } \\
\text { Junction }\end{array}$ & $\mathrm{CO}$ & 5.7 & 12.1 & 4 & 6 \\
\hline 816 & $\begin{array}{l}\text { Glenwood } \\
\text { Springs }\end{array}$ & $\mathrm{CO}$ & 7.0 & 2.1 & 4 & 6 \\
\hline 817 & Not used & 00 & 0.0 & 0.0 & 0 & 0 \\
\hline 818 & Not used & 00 & 0.0 & 0.0 & 0 & 0 \\
\hline 819 & Not used & 00 & 0.0 & 0.0 & 0 & 0 \\
\hline 820 & Cheyenne & WY & 7.3 & 2.1 & 4 & 51 \\
\hline 821 & $\begin{array}{l}\text { Yellowstone } \\
\text { Nat Pk }\end{array}$ & WY & 9.1 & 0.5 & 4 & 51 \\
\hline 822 & Wheatland & WY & 6.5 & 5.4 & 4 & 51 \\
\hline 823 & Rawlins & WY & 8.6 & 0.3 & 4 & 51 \\
\hline 824 & Worland & WY & 8.0 & 4.8 & 4 & 51 \\
\hline 825 & Riverton & WY & 8.4 & 2.6 & 4 & 51 \\
\hline 826 & Casper & WY & 6.9 & 4.5 & 4 & 51 \\
\hline 827 & Gillette & WY & 7.8 & 4.3 & 4 & 51 \\
\hline 828 & Sheridan & WY & 7.9 & 4.5 & 4 & 51 \\
\hline 829 & $\begin{array}{l}\text { Rock } \\
\text { Springs }\end{array}$ & WY & 8.4 & 1.0 & 4 & 51 \\
\hline 830 & Jackson & $W Y$ & 9.8 & 0.1 & 4 & 51 \\
\hline 831 & Kemmerer & WY & 9.6 & 0.3 & 4 & 51 \\
\hline 832 & Pocatello & ID & 7.1 & 3.3 & 4 & 13 \\
\hline 833 & Twin Falls & ID & 6.7 & 2.8 & 4 & 13 \\
\hline 834 & Idaho Falls & ID & 8.6 & 1.4 & 4 & 13 \\
\hline 835 & Lewiston & ID & 5.4 & 7.9 & 4 & 13 \\
\hline 836 & Boise & ID & 5.8 & 8.0 & 4 & 13 \\
\hline 837 & Boise & ID & 5.8 & 8.0 & 4 & 13 \\
\hline 838 & $\begin{array}{c}\text { Coeur D } \\
\text { Alene }\end{array}$ & ID & 6.5 & 2.8 & 4 & 13 \\
\hline 839 & Not used & 00 & 0.0 & 0.0 & 0 & 0 \\
\hline 840 & $\begin{array}{l}\text { Salt Lake } \\
\text { City/ Heber } \\
\text { City }\end{array}$ & UT & 7.6 & 0.5 & 4 & 45 \\
\hline 841 & $\begin{array}{l}\text { Salt Lake } \\
\text { City }\end{array}$ & UT & 5.8 & 9.9 & 4 & 45 \\
\hline
\end{tabular}

\begin{tabular}{|c|c|c|c|c|c|c|}
\hline 842 & Not used & 00 & 0.0 & 0.0 & 0 & 0 \\
\hline 843 & $\begin{array}{c}\text { Ogden/ } \\
\text { Logan }\end{array}$ & $\mathrm{UT}$ & 6.8 & 5.0 & 4 & 45 \\
\hline 844 & Ogden & $\mathrm{UT}$ & 5.9 & 9.0 & 4 & 45 \\
\hline 845 & $\begin{array}{c}\text { Southeast } \\
\text { Utah/ Green } \\
\text { River }\end{array}$ & $\mathrm{UT}$ & 6.0 & 9.0 & 4 & 45 \\
\hline 846 & Provo & $\mathrm{UT}$ & 6.0 & 9.0 & 4 & 45 \\
\hline 847 & $\begin{array}{c}\text { Southwest } \\
\text { Utah/ Cedar }\end{array}$ & $\mathrm{UT}$ & 6.0 & 5.0 & 4 & 45 \\
\hline 848 & Not used & 00 & 0.0 & 0.0 & 0 & 0 \\
\hline 849 & Not used & 00 & 0.0 & 0.0 & 0 & 0 \\
\hline 850 & Phoenix & $\mathrm{AZ}$ & 1.4 & 55.0 & 4 & 3 \\
\hline 851 & Phoenix & $\mathrm{AZ}$ & 1.4 & 55.0 & 4 & 3 \\
\hline 852 & Casa Grande & $\mathrm{AZ}$ & 1.6 & 49.0 & 4 & 3 \\
\hline 853 & $\begin{array}{c}\text { Buckeye/ } \\
\text { Yuma }\end{array}$ & $\mathrm{AZ}$ & 1.3 & 55.0 & 4 & 3 \\
\hline 854 & Not used & 00 & 0.0 & 0.0 & 0 & 0 \\
\hline 855 & Globe & $\mathrm{AZ}$ & 2.8 & 24.6 & 4 & 3 \\
\hline 856 & $\begin{array}{c}\text { Sierra Vista/ } \\
\text { Nogales }\end{array}$ & $\mathrm{AZ}$ & 2.9 & 10.0 & 4 & 3 \\
\hline 857 & Tucson & $\mathrm{AZ}$ & 1.7 & 36.0 & 4 & 3 \\
\hline 858 & Not used & 00 & 0.0 & 0.0 & 0 & 0 \\
\hline 859 & Show Low & $\mathrm{AZ}$ & 5.0 & 4.6 & 4 & 3 \\
\hline 860 & Flagstaff & $\mathrm{AZ}$ & 7.3 & 0.4 & 4 & 3 \\
\hline 861 & Not used & 00 & 0.0 & 0.0 & 0 & 0 \\
\hline 862 & Not used & 00 & 0.0 & 0.0 & 0 & 0 \\
\hline 863 & Prescott & $\mathrm{AZ}$ & 5.0 & 3.8 & 4 & 3 \\
\hline 864 & Kingman & $\mathrm{AZ}$ & 3.1 & 21.6 & 4 & 3 \\
\hline 865 & $\begin{array}{c}\text { Window } \\
\text { Rock }\end{array}$ & $\mathrm{AZ}$ & 6.7 & 1.9 & 4 & 3 \\
\hline 866 & Not used & 00 & 0.0 & 0.0 & 0 & 0 \\
\hline 867 & Not used & 00 & 0.0 & 0.0 & 0 & 0 \\
\hline Not used & 00 & 0.0 & 0.0 & 0 & 0 \\
\hline
\end{tabular}




\begin{tabular}{|c|c|c|c|c|c|c|}
\hline $\begin{array}{l}\text { Zip } \\
\text { Code }\end{array}$ & City & State & HDDk & CDHk & $\begin{array}{c}\text { Fuel } \\
\text { escalation } \\
\text { region }\end{array}$ & $\begin{array}{l}\text { State } \\
\text { No. }\end{array}$ \\
\hline 869 & Not used & 00 & 0.0 & 0.0 & 0 & 0 \\
\hline 870 & Bernalillo & $\mathrm{NM}$ & 4.7 & 7.6 & 4 & 32 \\
\hline 871 & $\begin{array}{l}\text { Albuquer- } \\
\text { que }\end{array}$ & NM & 4.4 & 11.0 & 4 & 32 \\
\hline 872 & $\begin{array}{l}\text { Albuquer- } \\
\text { que }\end{array}$ & NM & 4.4 & 11.0 & 4 & 32 \\
\hline 873 & Gallup & $\mathrm{NM}$ & 6.2 & 1.9 & 4 & 32 \\
\hline 874 & Farmington & $\mathrm{NM}$ & 5.7 & 5.0 & 4 & 32 \\
\hline 875 & Santa Fe & $\mathrm{NM}$ & 6.4 & 1.2 & 4 & 32 \\
\hline 876 & Not used & 00 & 0.0 & 0.0 & 0 & 0 \\
\hline 877 & Las Vegas & NM & 6.1 & 1.1 & 4 & 32 \\
\hline 878 & Socorro & $\mathrm{NM}$ & 4.1 & 11.0 & 4 & 32 \\
\hline 879 & $\begin{array}{l}\text { Truth or } \\
\text { Conseq. }\end{array}$ & NM & 3.4 & 14.6 & 4 & 32 \\
\hline 880 & Las Cruces & $\mathrm{NM}$ & 3.1 & 14.5 & 4 & 32 \\
\hline 881 & Clovis & $\mathrm{NM}$ & 4.1 & 10.0 & 4 & 32 \\
\hline 882 & Roswell & $\mathrm{NM}$ & 3.1 & 20.0 & 4 & 32 \\
\hline 883 & Carrizozo & $\mathrm{NM}$ & 4.3 & 7.2 & 4 & 32 \\
\hline 884 & Tucumcari & NM & 3.9 & 15.0 & 4 & 32 \\
\hline 885 & Not used & 00 & 0.0 & 0.0 & 0 & 0 \\
\hline 886 & Not used & 00 & 0.0 & 0.0 & 0 & 0 \\
\hline 887 & Not used & 00 & 0.0 & 0.0 & 0 & 0 \\
\hline 888 & Not used & 00 & 0.0 & 0.0 & 0 & 0 \\
\hline 889 & not used & 00 & 0.0 & 0.0 & 0 & 0 \\
\hline 890 & $\begin{array}{c}\text { Las Vegas' } \\
\text { Tonopah }\end{array}$ & NV & 5.8 & 5.9 & 4 & 28 \\
\hline 891 & Las Vegas & NV & 2.5 & 43.0 & 4 & 28 \\
\hline 892 & Not used & 00 & 0.0 & 0.0 & 0 & 0 \\
\hline 893 & Ely & NV & 7.7 & 0.7 & 4 & 28 \\
\hline 894 & Reno & NV & 6.0 & 2.2 & 4 & 28 \\
\hline 895 & Reno & NV & 6.0 & 2.2 & 4 & 28 \\
\hline 896 & Reno & NV & 6.0 & 2.2 & 4 & 28 \\
\hline 897 & Carson City & NV & 5.8 & 2.0 & 4 & 28 \\
\hline
\end{tabular}

\begin{tabular}{|c|c|c|c|c|c|c|}
\hline 898 & Elko & NV & 7.3 & 3.8 & 4 & 28 \\
\hline 899 & Not used & 00 & 0.0 & 0.0 & 0 & 0 \\
\hline 900 & Los Angeles & $\mathrm{CA}$ & 1.2 & 10.6 & 4 & 5 \\
\hline 901 & Los Angeles & $\mathrm{CA}$ & 1.2 & 10.6 & 4 & 5 \\
\hline 902 & Los Angeles & $\mathrm{CA}$ & 1.2 & 10.6 & 4 & 5 \\
\hline 903 & Inglewood & $\mathrm{CA}$ & 1.6 & 4.3 & 4 & 5 \\
\hline 904 & $\begin{array}{l}\text { Santa } \\
\text { Monica }\end{array}$ & $\mathrm{CA}$ & 1.9 & 1.9 & 4 & 5 \\
\hline 905 & Torrance & $\mathrm{CA}$ & 1.7 & 3.9 & 4 & 5 \\
\hline 906 & Whittier & $\mathrm{CA}$ & 2.0 & 10.2 & 4 & 5 \\
\hline 907 & San Pedro & $\mathrm{CA}$ & 1.5 & 7.8 & 4 & 5 \\
\hline 908 & Long Beach & $\mathrm{CA}$ & 1.5 & 7.8 & 4 & 5 \\
\hline 909 & Not used & 00 & 0.0 & 0.0 & 0 & 0 \\
\hline 910 & Pasadena & $\mathrm{CA}$ & 1.6 & 11.0 & 4 & 5 \\
\hline 911 & Pasadena & $\mathrm{CA}$ & 1.6 & 11.0 & 4 & 5 \\
\hline 912 & Glendale & $\mathrm{CA}$ & 1.7 & 11.4 & 4 & 5 \\
\hline 913 & Van Nuys & $\mathrm{CA}$ & 1.7 & 11.4 & 4 & 5 \\
\hline 914 & Van Nuys & $\mathrm{CA}$ & 1.7 & 11.4 & 4 & 5 \\
\hline 915 & Burbank & $\mathrm{CA}$ & 1.7 & 11.4 & 4 & 5 \\
\hline 916 & $\begin{array}{c}\text { North } \\
\text { Hollywood }\end{array}$ & $\mathrm{CA}$ & 1.7 & 11.4 & 4 & 5 \\
\hline 917 & Covina & $\mathrm{CA}$ & 2.0 & 10.2 & 4 & 5 \\
\hline 918 & Alhambra & $\mathrm{CA}$ & 1.6 & 11.0 & 4 & 5 \\
\hline 919 & San Diego & $\mathrm{CA}$ & 1.3 & 4.6 & 4 & 5 \\
\hline 920 & San Diego & $\mathrm{CA}$ & 1.3 & 4.6 & 4 & 5 \\
\hline 921 & San Diego & $\mathrm{CA}$ & 1.3 & 4.6 & 4 & 5 \\
\hline 922 & $\begin{array}{l}\text { Palm } \\
\text { Springs }\end{array}$ & $\mathrm{CA}$ & 1.1 & 54.0 & 4 & 5 \\
\hline 923 & $\begin{array}{l}\text { San Bern./ } \\
\text { Victorville/ } \\
\text { Redlands }\end{array}$ & $\mathrm{CA}$ & 2.5 & 16.0 & 4 & 5 \\
\hline 924 & $\begin{array}{c}\text { San } \\
\text { Bernardino }\end{array}$ & $\mathrm{CA}$ & 1.8 & 17.8 & 4 & 5 \\
\hline 925 & Riverside & $\mathrm{CA}$ & 1.8 & 14.0 & 4 & 5 \\
\hline
\end{tabular}




\begin{tabular}{|c|c|c|c|c|c|c|}
\hline $\begin{array}{l}\text { Zip } \\
\text { Code }\end{array}$ & City & State & HDDk & CDHk & $\begin{array}{c}\begin{array}{c}\text { Fuel } \\
\text { escalation } \\
\text { region }\end{array} \\
\end{array}$ & $\begin{array}{l}\text { State } \\
\text { No. }\end{array}$ \\
\hline 926 & Santa Ana & $\mathrm{CA}$ & 1.4 & 6.9 & 4 & 5 \\
\hline 927 & Santa Ana & $\mathrm{CA}$ & 1.4 & 6.9 & 4 & 5 \\
\hline 928 & Anaheim & $\mathrm{CA}$ & 1.4 & 6.9 & 4 & 5 \\
\hline 929 & Not used & 00 & 0.0 & 0.0 & 0 & 0 \\
\hline 930 & $\begin{array}{l}\text { Ventural } \\
\text { Oxnard }\end{array}$ & $\mathrm{CA}$ & 2.1 & 1.2 & 4 & 5 \\
\hline 931 & $\begin{array}{l}\text { Santa } \\
\text { Barbara }\end{array}$ & $\mathrm{CA}$ & 2.5 & 0.9 & 4 & 5 \\
\hline 932 & $\begin{array}{l}\text { Bakersfield/ } \\
\text { Visalia }\end{array}$ & $\mathrm{CA}$ & 2.5 & 19.0 & 4 & 5 \\
\hline 933 & Bakersfield & $\mathrm{CA}$ & 2.1 & 30.0 & 4 & 5 \\
\hline 934 & $\begin{array}{l}\text { San Luis } \\
\text { Obispo }\end{array}$ & $\mathrm{CA}$ & 2.5 & 1.1 & 4 & 5 \\
\hline 935 & Lancaster & $\mathrm{CA}$ & 2.9 & 21.0 & 4 & 5 \\
\hline 936 & Fresno & $\mathrm{CA}$ & 2.6 & 19.4 & 4 & 5 \\
\hline 937 & Fresno & $\mathrm{CA}$ & 2.6 & 19.4 & 4 & 5 \\
\hline 938 & Not used & 00 & 0.0 & 0.0 & 0 & 0 \\
\hline 939 & Monterey & $\mathrm{CA}$ & 3.2 & 0.1 & 4 & 5 \\
\hline 940 & $\begin{array}{c}\text { So. San } \\
\text { Francisco }\end{array}$ & $\mathrm{CA}$ & 3.1 & 0.3 & 4 & 5 \\
\hline 941 & $\begin{array}{c}\text { San } \\
\text { Francisco } \\
\end{array}$ & $\mathrm{CA}$ & 3.1 & 0.2 & 4 & 5 \\
\hline 942 & $\begin{array}{c}\text { Sacramento/ } \\
\text { Placerville }\end{array}$ & $\mathrm{CA}$ & 4.1 & 7.8 & 4 & 5 \\
\hline 943 & Palo Alto & $\mathrm{CA}$ & 2.9 & 0.7 & 4 & 5 \\
\hline 944 & San Mateo & $\mathrm{CA}$ & 2.6 & 1.2 & 4 & 5 \\
\hline 945 & Concord & $\mathrm{CA}$ & 3.0 & 3.0 & 4 & 5 \\
\hline 946 & Oakland & $\mathrm{CA}$ & 2.9 & 0.4 & 4 & 5 \\
\hline 947 & Berkeley & $\mathrm{CA}$ & 3.0 & 0.3 & 4 & 5 \\
\hline 948 & Richmond & $\mathrm{CA}$ & 2.7 & 0.4 & 4 & 5 \\
\hline 949 & San Rafael & $\mathrm{CA}$ & 2.5 & 1.9 & 4 & 5 \\
\hline 950 & Gilroy & $\mathrm{CA}$ & 3.4 & 0.1 & 4 & 5 \\
\hline 951 & San Jose & $\mathrm{CA}$ & 2.4 & 1.4 & 4 & 5 \\
\hline 952 & Stockton & $\mathrm{CA}$ & 2.7 & 13.0 & 4 & 5 \\
\hline 953 & Merced & $\mathrm{CA}$ & 2.7 & 14.0 & 4 & 5 \\
\hline
\end{tabular}

\begin{tabular}{|c|c|c|c|c|c|c|}
\hline 954 & Santa Rosa & CA & 3.0 & 1.2 & 4 & 5 \\
\hline 955 & Eureka & CA & 4.7 & 0.0 & 4 & 5 \\
\hline 956 & $\begin{array}{c}\text { Sacramento/ } \\
\text { Placerville }\end{array}$ & CA & 4.1 & 7.8 & 4 & 5 \\
\hline 957 & $\begin{array}{c}\text { Pollock } \\
\text { Pines }\end{array}$ & CA & 6.0 & 1.0 & 4 & 5 \\
\hline 958 & Sacramento & CA & 2.5 & 12.0 & 4 & 5 \\
\hline 959 & Marysville & CA & 2.6 & 15.0 & 4 & 5 \\
\hline 960 & Redding & CA & 2.5 & 28.0 & 4 & 5 \\
\hline 961 & Susanville & CA & 6.2 & 2.2 & 4 & 5 \\
\hline 962 & Not used & 00 & 0.0 & 0.0 & 0 & 0 \\
\hline 963 & Not used & 00 & 0.0 & 0.0 & 0 & 0 \\
\hline 964 & Not used & O0 & 0.0 & 0.0 & 0 & 0 \\
\hline 965 & Not used & O0 & 0.0 & 0.0 & 0 & 0 \\
\hline 966 & Not used & O0 & 0.0 & 0.0 & 0 & 0 \\
\hline 967 & Honolulu & HI & 0.0 & 20.0 & 4 & 12 \\
\hline 968 & Honolulu & HI & 0.0 & 30.0 & 4 & 12 \\
\hline 969 & Not used & 00 & 0.0 & 0.0 & 0 & 0 \\
\hline 970 & Hood River & OR & 5.0 & 1.5 & 4 & 38 \\
\hline 971 & Portland & OR & 4.7 & 1.9 & 4 & 38 \\
\hline 972 & Portland & OR & 4.7 & 1.9 & 4 & 38 \\
\hline 973 & Salem & OR & 5.0 & 1.0 & 4 & 38 \\
\hline 974 & Eugene & OR & 4.8 & 1.3 & 4 & 38 \\
\hline 975 & Medford & OR & 4.8 & 6.2 & 4 & 38 \\
\hline 976 & Klamath & OR & 6.6 & 2.4 & 4 & 38 \\
\hline 977 & Bend & OR & 7.1 & 0.6 & 4 & 38 \\
\hline 978 & Pendleton & OR & 5.3 & 8.1 & 4 & 38 \\
\hline 979 & Ontario & OR & 5.7 & 10.0 & 4 & 38 \\
\hline 980 & Seattle & WA & 5.1 & 1.0 & 4 & 48 \\
\hline 981 & Seattle & WA & 5.1 & 1.0 & 4 & 48 \\
\hline 982 & Everett & WA & 5.4 & 0.2 & 4 & 48 \\
\hline 983 & Tacoma & WA & 5.1 & 1.0 & 4 & 48 \\
\hline
\end{tabular}




\begin{tabular}{|c|c|c|c|c|c|c|}
\hline $\begin{array}{c}\text { Zip } \\
\text { Code }\end{array}$ & City & State & HDDk & CDHk & $\begin{array}{c}\text { Fuel } \\
\text { escalation } \\
\text { region }\end{array}$ & $\begin{array}{c}\text { State } \\
\text { No. }\end{array}$ \\
\hline 984 & Tacoma & WA & 4.8 & 0.5 & 4 & 48 \\
\hline 985 & Olympia & WA & 5.7 & 0.3 & 4 & 48 \\
\hline 986 & Vancouver & WA & 5.0 & 1.7 & 4 & 48 \\
\hline 987 & Not used & 00 & 0.0 & 0.0 & 0 & 0 \\
\hline 988 & Wenatchee & WA & 5.7 & 7.6 & 4 & 48 \\
\hline 989 & Yakima & WA & 6.0 & 4.1 & 4 & 48 \\
\hline 990 & Spokane & WA & 6.9 & 3.5 & 4 & 48 \\
\hline 991 & Spokane & WA & 6.9 & 3.5 & 4 & 48 \\
\hline 992 & Spokane & WA & 6.9 & 3.5 & 4 & 48 \\
\hline 993 & Richland & WA & 4.7 & 9.8 & 4 & 48 \\
\hline 994 & Clarkston & WA & 5.4 & 8.0 & 4 & 48 \\
\hline 995 & Anchorage & AK & 11.0 & 0.0 & 4 & 2 \\
\hline 996 & Anchorage & AK & 11.0 & 0.0 & 4 & 2 \\
\hline 997 & Fairbanks & AK & 14.0 & 0.0 & 4 & 2 \\
\hline 998 & Juneau & AK & 9.0 & 0.0 & 4 & 2 \\
\hline 999 & Ketchikan & AK & 7.0 & 0.0 & 4 & 2 \\
\hline
\end{tabular}




\section{Appendix B. Coefficients Used to Calculate Savings for Floor ${ }^{*}$ and Building Foundation ${ }^{* *}$ Insulation.}

\begin{tabular}{|c|c|c|}
\hline $\begin{array}{c}\text { R- } \\
\text { value }\end{array}$ & $\beta_{\mathbf{h}}$ & $\beta_{\mathbf{c}}$ \\
\hline \multicolumn{2}{|c|}{$\begin{array}{c}\text { Plastic foam on upper half } \\
\text { of deep basement, base } \\
\text { R-value is } 2.5^{* *}\end{array}$} \\
\hline 4 & 20.69 & 0.34 \\
\hline 5 & 21.70 & 0.37 \\
\hline 8 & 23.62 & 0.44 \\
\hline 10 & 24.48 & 0.47 \\
\hline 12 & 25.18 & 0.50 \\
\hline 15 & 26.07 & 0.54 \\
\hline $\begin{array}{c}\text { Plastic foam on full height } \\
\text { of deep basement, base } \\
\text { R-value is } 2.5 * *\end{array}$ \\
\hline 4 & 28.57 & 0.45 \\
\hline 5 & 30.00 & 0.47 \\
\hline 8 & 32.75 & 0.50 \\
\hline 10 & 34.00 & 0.51 \\
\hline 12 & 35.03 & 0.52 \\
\hline 15 & 35.35 & 0.54 \\
\hline $\begin{array}{c}\text { Plastic foam on full height } \\
\text { of shallow basement, base } \\
\text { R-value is } 2.5^{* *}\end{array}$ \\
\hline 4 & 44.35 & 0.95 \\
\hline 5 & 46.38 & 0.99 \\
\hline 10 & 50.04 & 1.06 \\
\hline 12 & 52.75 & 1.10 \\
\hline 15 & 54.17 & 1.12 \\
\hline
\end{tabular}

\begin{tabular}{|c|c|c|}
\hline $\begin{array}{c}\text { R- } \\
\text { value }\end{array}$ & $\beta_{h}$ & $\beta_{c}$ \\
\hline \multicolumn{3}{|c|}{$\begin{array}{c}\text { Batt insulation on inside of } \\
\text { deep basement wall, base } \\
\text { R-value is } 2.5^{* *}\end{array}$} \\
\hline 11 & 34.24 & 0.51 \\
\hline 19 & 35.20 & 0.52 \\
\hline 30 & 37.55 & 0.53 \\
\hline \multicolumn{3}{|c|}{$\begin{array}{l}\text { Batt insulation on inside of } \\
\text { shallow basement wall, } \\
\text { base R-value is } 2.5^{* *}\end{array}$} \\
\hline 11 & 51.36 & 1.08 \\
\hline 19 & 52.48 & 1.10 \\
\hline 30 & 54.98 & 1.13 \\
\hline \multicolumn{3}{|c|}{$\begin{array}{l}\text { Slab on grade - Vertical } 2 \\
\text { feet, base R-value is } 1.0^{* *}\end{array}$} \\
\hline 4 & 2.79 & 0.23 \\
\hline 5 & 2.94 & 0.24 \\
\hline 8 & 3.25 & 0.25 \\
\hline 10 & 3.40 & 0.25 \\
\hline 12 & 3.53 & 0.25 \\
\hline 15 & 3.70 & 0.25 \\
\hline \multicolumn{3}{|c|}{$\begin{array}{l}\text { Slab on grade - vertical } 4 \\
\text { feet, base R-value is } 1.0^{*}\end{array}$} \\
\hline 4 & 3.56 & 0.23 \\
\hline 5 & 3.78 & 0.24 \\
\hline 8 & 4.25 & 0.25 \\
\hline 10 & 4.50 & 0.25 \\
\hline 12 & 4.72 & 0.25 \\
\hline 15 & 5.03 & 0.25 \\
\hline
\end{tabular}

\begin{tabular}{|c|c|c|}
\hline $\begin{array}{c}\text { R- } \\
\text { value }\end{array}$ & $\beta_{\mathrm{h}}$ & $\beta_{c}$ \\
\hline
\end{tabular}

Wood-framed floor insulation,

base $\mathrm{R}$-value is $4.0^{*}$

\begin{tabular}{|c|c|c|}
\hline 11 & 1.7 & .12 \\
\hline 19 & 1.96 & .12 \\
\hline 30 & 2.22 & .12 \\
\hline \multicolumn{3}{|c|}{$\begin{array}{c}\text { Metal-framed floor } \\
\text { insulation, } \\
\text { base R-value is } 4.0^{*}\end{array}$} \\
\hline 11 & 1.05 & .07 \\
\hline 19 & 1.33 & .09 \\
\hline 30 & 1.52 & .11 \\
\hline
\end{tabular}

Concrete-masonry crawl space walls - plastic foam, base $\mathrm{R}$-value is $2.5^{* *}$

\begin{tabular}{|c|c|c|}
\hline 5 & 19.51 & .83 \\
\hline 7 & 20.59 & .86 \\
\hline 10 & 21.56 & .88 \\
\hline 14 & 22.37 & .90 \\
\hline \multicolumn{3}{|c|}{$\begin{array}{c}\text { Concrete-masonry crawl } \\
\text { space walls - batts, } \\
\text { base R-value is } 2.5^{* *}\end{array}$} \\
\hline 11 & 21.80 & .93 \\
\hline 13 & 22.20 & .94 \\
\hline
\end{tabular}

$* *$ per linear foot 


\section{Appendix C: The Modified Zone Heat Transfer Model}

The modified zone heat transfer model provides a more accurate estimate of total heat transfer through a wall with highly conductive framing members. The following Fortran listing was used to calculate representative U-values for metal frame walls using this method. It also includes a parallel-path heat transfer calculation for wood frame walls. This program varies the sheathing thickness from 0 to 2 inches, the wall cavity insulation from an R-value of 0.9 (an empty air space) to R-22, and varies the thickness of the cavity corresponding to the thickness of the batt insulation product. The output files contain the U-value and cost for every combination of these factors. Before using this data in the Zip computer program, any combination of sheathing and cavity insulation that offered less insulation (i.e. a higher U-value) for a higher cost than an alternative combination was deleted.

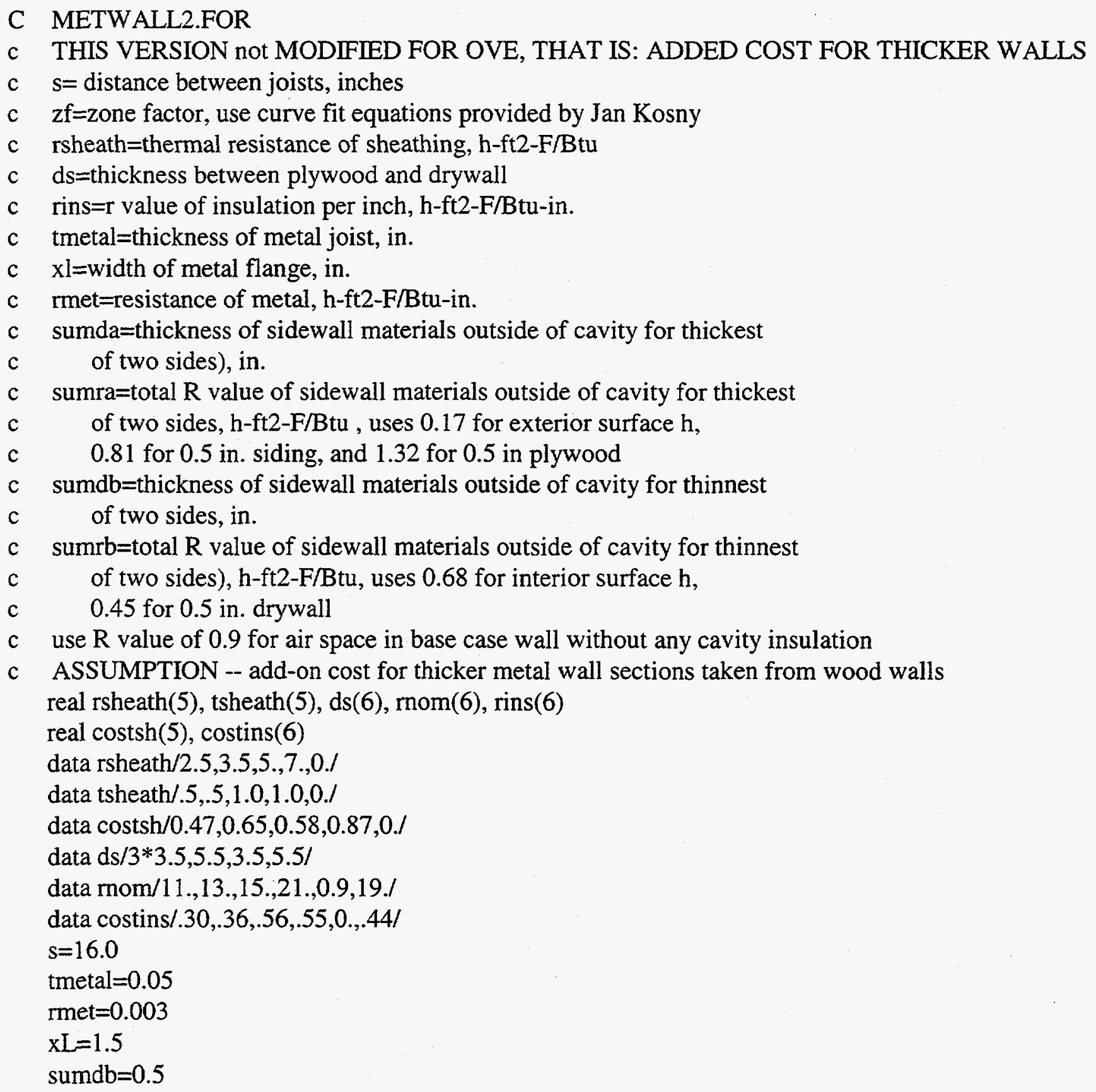




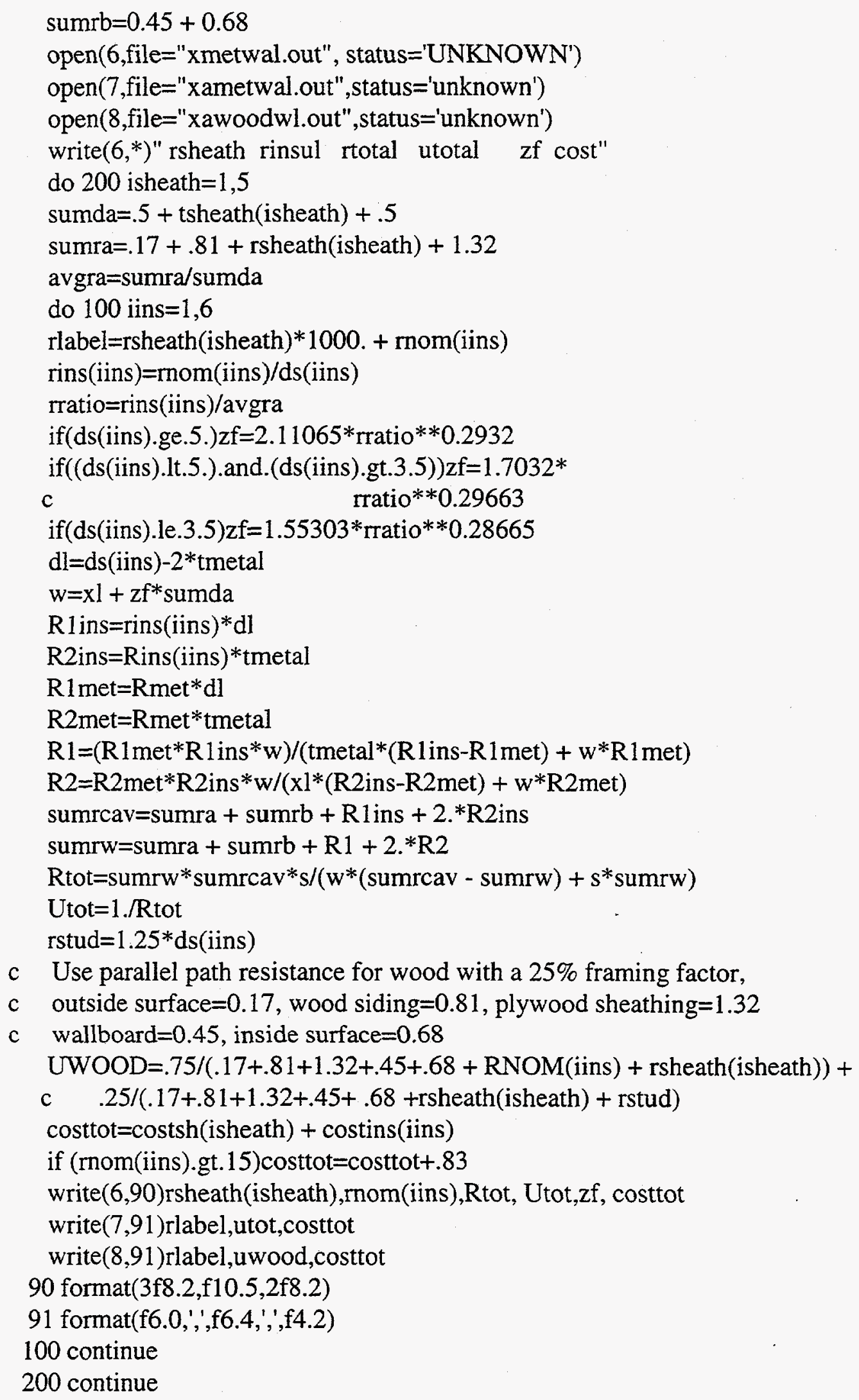


Appendix D: Insulation Cost Survey Forms and Selected Results

Company Name:

Address:

Contact:

Phone/Fax:

$\square$ withhold company name from database
From: Steven Winter Associates, Inc.

Phone: (203) 857-0200

Fax: (203) 852-0741

Attention: Peter Stratton

\section{Residential Retrofit Costs \\ National Survey \\ Oak Ridge National Laboratory}

\begin{tabular}{|c|c|c|c|c|c|c|c|c|}
\hline & \multirow{2}{*}{ Material } & \multicolumn{7}{|c|}{ Cost per $\mathrm{ft}^{2}$ (including labor, materials, OH, profit) } \\
\hline & & $\mathrm{R}-11$ & R-19 & $\mathrm{R}-30$ & R-38 & R-49 & R-22 & R-25 \\
\hline \multirow{4}{*}{$\begin{array}{l}\text { Attic } \\
1200 f^{2} \text { floor pull down } \\
\text { stair access }\end{array}$} & Fiberglass batt & $\mathrm{H}^{2}$ & Ati & $\mathbb{H}^{2}$ & $N^{2}$ & $\mathbb{A}^{2}$ & $\mathrm{At}^{2}$ & Hit \\
\hline & Blown fiberglass & $/ \mathrm{At}^{2}$ & $\mathrm{Atr}^{2}$ & $m t^{2}$ & $\mathrm{HA}^{2}$ & $\mathrm{~m}^{2}$ & & \\
\hline & Blown cellulose & $\mathrm{At}^{2}$ & $\mathrm{H}^{2}$ & $\mathrm{At}^{2}$ & $\mathbb{N}^{2}$ & $\mathbb{A}^{2}$ & & \\
\hline & Blown rock wool & $\mathbb{H}^{2}$ & $\mathrm{Ht}^{2}$ & $\mathrm{At}^{2}$ & $\mathrm{HAt}^{2}$ & $\mathbb{A}^{2}$ & & \\
\hline \multirow{2}{*}{$\begin{array}{l}\text { Interior/Exterior } \\
\text { Wall } \\
200 f^{2} \text { one side unfinished } \\
\text { with open access }\end{array}$} & \multirow[t]{2}{*}{ Fiberglass batt } & $R-11$ & $R-13$ & R-19 & R-22 & R-38 & R-49 & \\
\hline & & $\mathrm{Ht}^{2}$ & $\mathrm{HAt}^{2}$ & $\mathbb{A t}^{2}$ & $\mathrm{At}^{2}$ & $\mathrm{Ht}^{2}$ & $\mathrm{HA}^{2}$ & \\
\hline \multirow{2}{*}{$\begin{array}{l}\text { Exterior Walls } \\
\text { gooft' } 2 \times 4 \mathrm{~s} @ 16^{\prime \prime} \text { o.c. } \\
\text { inlcuding wall surface } \\
\text { repair }\end{array}$} & \multirow[t]{2}{*}{ Blown cellulose } & $3 \mathrm{lb} / \mathrm{t}^{3}$ & $4 \mathrm{lb} / \mathrm{ft}^{3}$ & \multirow{2}{*}{\multicolumn{2}{|c|}{$\begin{array}{c}\text { Blown } \\
\text { fiberglass }\end{array}$}} & $R-11$ & & \\
\hline & & $1 \mathrm{H}^{2}$ & $\mathrm{At}^{2}$ & & & $\mathrm{HAt}^{2}$ & & \\
\hline \multirow{4}{*}{$\begin{array}{l}\text { Crawl Space Wall } \\
560^{\prime} \text { fit }^{\prime} \text { high } \times 140^{\prime} \\
\text { long - } 3^{\prime} \times 4^{\prime} \text { access }\end{array}$} & \multirow{2}{*}{$\begin{array}{l}\text { Extruded } \\
\text { Polystyrene }\end{array}$} & R-4 & R-5 & R-7.5 & R-10 & $\mathrm{R}-15$ & R-19 & \\
\hline & & $A^{2}$ & $\mathrm{At}^{2}$ & $\mathbb{A t}^{2}$ & IAt2 & $\mathrm{HA}^{2}$ & s & \\
\hline & \multirow[t]{2}{*}{ Fiberglass batts } & $R-11$ & $\mathrm{R}-13$ & R-15 & $\mathrm{R}-19$ & & & \\
\hline & & $\pi t^{2}$ & $\mathrm{At}^{2}$ & $A^{2}$ & $\mathbb{A t}^{2}$ & & & \\
\hline \multirow{2}{*}{$\begin{array}{l}\text { Floor } \\
1200 f^{2} 4^{\prime} \text { high crawl } \\
\text { space } 3^{\prime} \times 4^{\prime} \text { access }\end{array}$} & \multirow[t]{2}{*}{ Fiberglass batts } & $\mathrm{R}-11$ & $R-13$ & $\mathrm{R}-15$ & $R-19$ & $\mathrm{R}-25$ & & \\
\hline & & $\mathbb{N}^{2}$ & $\mathrm{HAt}^{2}$ & $\mathrm{H}^{2}$ & $\mathrm{At}^{2}$ & $\left(\mathrm{At}^{2}\right.$ & & \\
\hline \multirow{2}{*}{$\begin{array}{l}\text { Basement Wall } \\
90 \mathrm{ft}^{2} 140^{\prime} \text { long with } 2 \times 2 \\
\text { at top, center, and bottom } \\
\text { of wall }\end{array}$} & \multirow{2}{*}{$\begin{array}{l}\text { Fiberglass batts with } \\
\text { flame resistant } \\
\text { polypropylene face }\end{array}$} & $\mathrm{R}-11$ & & & & & & \\
\hline & & $\$$ & & & & & & \\
\hline
\end{tabular}

Company Name:

Address:

Contact:
Phone/Fax:

$\square$ withhold company name from database 
From: Steven Winter Associates, Inc.

Phone: (203) 857-0200

Fax: (203) 852-0741

Attention: Peter Stratton

\section{Residential New Construction Costs}

\section{National Survey}

Oak Ridge National Laboratory

\begin{tabular}{|c|c|c|c|c|c|c|c|c|c|c|c|}
\hline & \multirow{2}{*}{\multicolumn{2}{|c|}{ Material }} & \multicolumn{9}{|c|}{ Cost per $\mathrm{ft}^{2}$ (including material, labor, $\mathrm{OH}$, profit) } \\
\hline & & & $\mathrm{R}-11$ & $\mathrm{R}-19$ & $\mathrm{R}-22$ & R-25 & R-30 & $\mathrm{R}-38$ & $R-49$ & R-60 & \\
\hline \multirow{4}{*}{$\begin{array}{l}\text { Attic } \\
1200 f^{2} \text { floor } \\
30^{\prime} \times 40^{\prime}\end{array}$} & \multicolumn{2}{|c|}{$\begin{array}{l}\text { Fiberglass } \\
\text { Batt }\end{array}$} & $/ \mathrm{t}^{2}$ & $A^{2}$ & $/ \mathrm{t}^{2}$ & $\mathrm{~s}^{2}$ & $/ \mathbb{t}^{2}$ & $/ \mathrm{tt}^{2}$ & $/ \mathbb{A}^{2}$ & $/ \mathrm{t}^{2}$ & \\
\hline & \multicolumn{2}{|c|}{$\begin{array}{l}\text { Blown } \\
\text { fiberglass }\end{array}$} & $/ \mathrm{t}^{2}$ & $\mathrm{At}^{2}$ & $/ \mathrm{At}^{2}$ & & $\mathbb{A}^{2}$ & $\mathrm{At}^{2}$ & $/ \mathrm{ft}^{2}$ & $1 / t^{2}$ & \\
\hline & \multicolumn{2}{|c|}{$\begin{array}{l}\text { Blown rock } \\
\text { wool }\end{array}$} & $\mathbb{A t}^{2}$ & $/ t^{2}$ & $\mathrm{AH}^{2}$ & & $\mathbb{H}^{2}$ & $2 \mathrm{t}^{2}$ & $\pi t^{2}$ & $\mathrm{At}^{2}$ & \\
\hline & \multicolumn{2}{|l|}{$\begin{array}{l}\text { Blown } \\
\text { cellulose }\end{array}$} & $/ t^{2}$ & $/ t^{2}$ & $\mathrm{At}^{2}$ & & $\mathrm{IIN}^{2}$ & it & $\mathrm{At}^{2}$ & $A t^{2}$ & \\
\hline \multirow{2}{*}{$\begin{array}{l}\text { Cathedral } \\
\text { Ceiling } \\
500 \mathrm{ft}^{2}\end{array}$} & & R-11 & $R-13$ & $R-15$ & R-19 & R-21 & R-22 & $R-30$ & R-38 & $R-49$ & $R-60$ \\
\hline & & $\begin{array}{ll} & \\
& H \mathrm{H}^{2} \\
\end{array}$ & $\mathrm{At}^{2}$ & $/ \mathrm{t}^{2}$ & $\mathbb{A t}^{2}$ & $1 \mathbb{A}^{2}$ & $\pi^{2}$ & $/ \mathrm{t}^{2}$ & $/ \mathrm{H}^{2}$ & $\mathrm{Aft^{2 }}$ & $\$$ \\
\hline \multirow{2}{*}{$\begin{array}{l}\text { Interior/Exterior } \\
\text { Walls } \\
200 \mathrm{ft}^{2} \quad 8^{\prime} \times 25^{\prime}\end{array}$} & \multirow{2}{*}{\multicolumn{2}{|c|}{$\begin{array}{l}\text { Fiberglass } \\
\text { batt }\end{array}$}} & $R-11$ & R-13 & $R-15$ & $R-19$ & $R-21$ & $\mathrm{R}-22$ & R-30 & R-38 & $R-49$ \\
\hline & & & $\mathrm{At}^{2}$ & $A^{\prime t^{2}}$ & $\mathrm{At}^{2}$ & $\mathrm{Ift}^{2}$ & $\mathbb{A t}^{2}$ & $/ \mathrm{tt}^{2}$ & $/ t^{2}$ & $\pi t^{2}$ & $\$$ \\
\hline \multirow{4}{*}{$\begin{array}{l}\text { Exterior Wall } \\
900 \mathrm{ft}^{2}-8^{\prime} \times 112.5^{\prime}\end{array}$} & \multirow{2}{*}{\multicolumn{2}{|c|}{$\begin{array}{l}\text { Foam } \\
\text { sheathing } \\
\text { board }\end{array}$}} & $R-1.3$ & R-3.6 & $R-4$ & $R-4.5$ & $R-5$ & R-5.4 & R-7.2 & $R-9$ & $R-10$ \\
\hline & & & $1 / \mathrm{t}^{2}$ & $/ \pi^{2}$ & $\mathbb{A t}^{2}$ & $\mathrm{At}^{2}$ & $\mathrm{At}^{2}$ & $1 \mathrm{At}^{2}$ & $1 t^{2}$ & $\mathbb{A}^{2}$ & $\$$ \\
\hline & \multirow{2}{*}{\multicolumn{2}{|c|}{$\begin{array}{l}\text { Fiberglass } \\
\text { batts }\end{array}$}} & $R-11$ & $\mathrm{R}-13$ & $R-15$ & $R-19$ & $R-21$ & \multirow{2}{*}{\multicolumn{2}{|c|}{$\begin{array}{c}\text { Cellulose Wall } \\
\text { Spray } \\
3 \mathrm{lb} / \mathrm{ft}^{3}\end{array}$}} & $2 \times 4$ & $2 \times 6$ \\
\hline & & & $\quad \mathbb{A H}^{2}$ & $\mathrm{At}^{2}$ & $\quad / \mathbb{t}^{2}$ & . $/ \mathbb{H}^{2}$ & $\mathrm{At}^{2}$ & & & 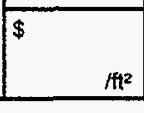 & \\
\hline \multirow{2}{*}{$\begin{array}{l}\text { Band Joist } \\
140 \mathrm{ft}^{2} 2 \times 10\end{array}$} & \multirow{2}{*}{\multicolumn{2}{|c|}{$\begin{array}{l}\text { Fiberglass } \\
\text { batts }\end{array}$}} & $R-11$ & $R-13$ & $R-19$ & R-30 & & & & & \\
\hline & & & $/ \mathrm{tt}^{2}$ & $1 / \mathbb{t}^{2}$ & $\mathrm{HH}^{2}$ & $\mathrm{At}^{2}$ & & & & & \\
\hline \multirow{4}{*}{$\begin{array}{l}\text { Crawl Space } \\
\text { Wall Interior } \\
560 f^{2}- \\
4^{\prime} \text { high } \times 140^{\prime} \text { long } \\
\text { with } 3^{\prime} \times 4^{\prime} \text { access }\end{array}$} & \multirow{2}{*}{\multicolumn{2}{|c|}{$\begin{array}{l}\text { Extruded } \\
\text { polystyrene }\end{array}$}} & $R-4$ & R-5 & R-7.5 & $R-10$ & $R-15$ & R-19 & & & \\
\hline & & & $\quad / t^{2}$ & $/ \mathrm{At}^{2}$ & $\mathrm{At}^{2}$ & $\mathrm{At}^{2}$ & $\mathbb{A t}^{2}$ & $\$$ & & & \\
\hline & \multirow{2}{*}{\multicolumn{2}{|c|}{$\begin{array}{l}\text { Fiberglass } \\
\text { batts }\end{array}$}} & $\mathrm{R}-11$ & $\mathrm{R}-13$ & $R-15$ & $\mathrm{R}-19$ & & & & & \\
\hline & & & $/ \mathrm{tt}^{2}$ & $/ \mathrm{ft}^{2}$ & $\mathrm{At}^{2}$ & $/ \mathrm{At}^{2}$ & & & & & \\
\hline \multirow[t]{2}{*}{ Exterior } & \multirow{2}{*}{\multicolumn{2}{|c|}{$\begin{array}{l}\text { Fiberglass } \\
\text { batts }\end{array}$}} & R-5 & $R-10$ & $R-15$ & $\mathrm{R}-20$ & & & & & \\
\hline & & & $A \mathbb{t}^{2}$ & $/ \mathrm{H}^{2}$ & $\mathbb{A t}^{2}$ & $\mathrm{At}^{2}$ & & & & & \\
\hline \multirow{2}{*}{$\begin{array}{l}\text { Floor } \\
1200 f^{2} \quad 4^{\prime} \text { crawl } \\
\text { space } w / 3^{\prime} \times 4^{\prime} \text { door }\end{array}$} & \multirow{2}{*}{\multicolumn{2}{|c|}{$\begin{array}{l}\text { Fiberglass } \\
\text { batts }\end{array}$}} & $R-11$ & $R-13$ & $R-15$ & $R-19$ & R-25 & & & & \\
\hline & & & $\$$ & $\$$ & $1 \mathbb{A t}^{2}$ & $\$$ & $\$$ & & & & \\
\hline
\end{tabular}

Company Name:

$\square$ withhold company name from database

Address:

Contact:

Phone/Fax: 
From: Steven Winter Associates, Inc.

Phone: (203) 857-0200

Fax: (203) 852-0741

Attention: Peter Stratton

\section{Residential New Construction Costs}

\section{National Survey}

Oak Ridge National Laboratory

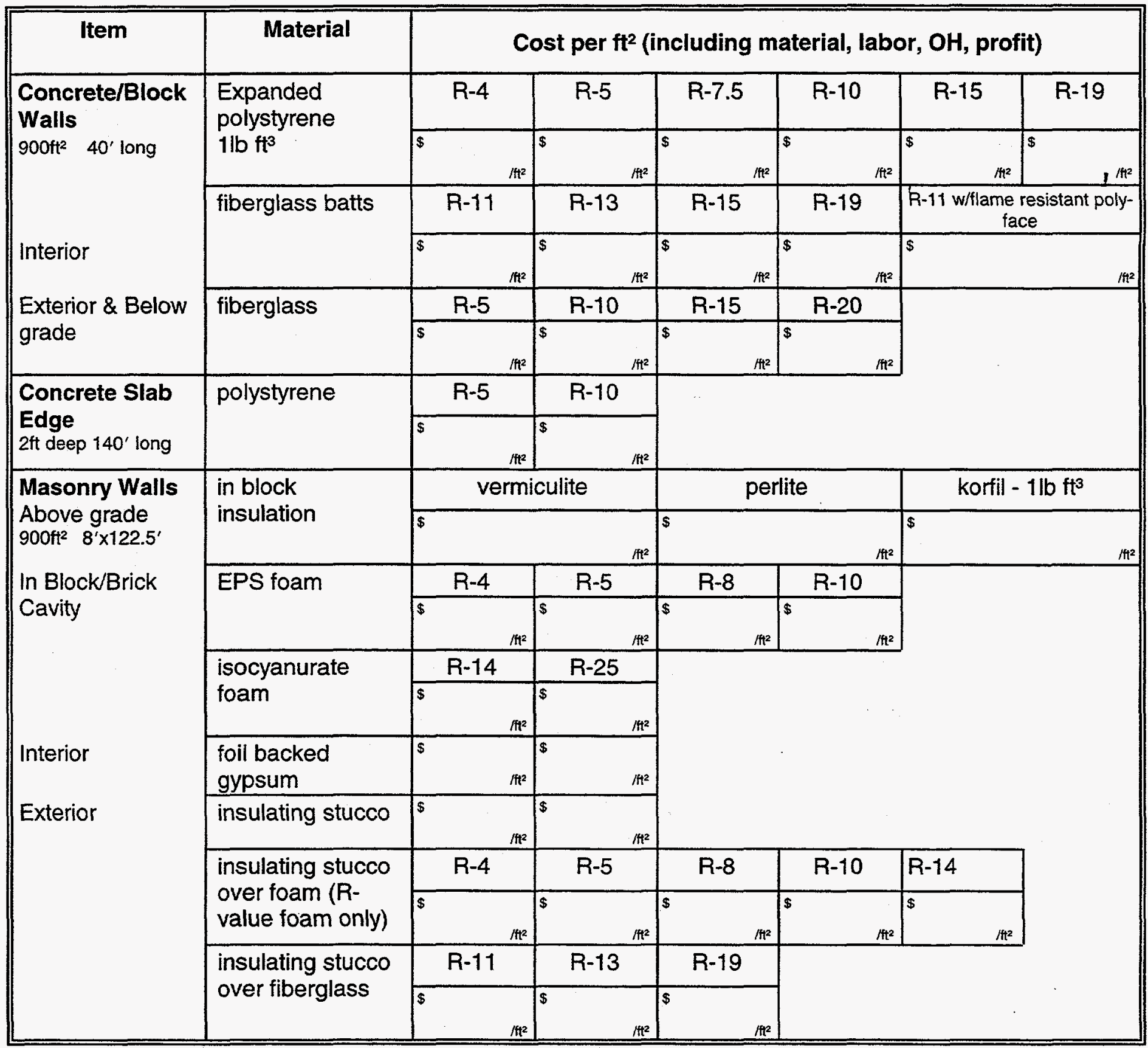


Company Name:

Address:

Contact:

Phone/Fax:

口 withhold company name from database
From: Steven Winter Associates, Inc.

Phone: (203) 857-0200

Fax: (203) 852-0741

Attention: Peter Stratton

1. Assume: $\mathbf{- 1 2 0 0}$ sq.ft. single-story house (30ft $\mathrm{x}$ 40ft)

- 6/12 roof pitch, flat ceiling

- 19 trusses at $24^{\prime \prime}$ oc and 2 frame gables

What are the increased framing costs associated with increasing the thickness of attic insulation from (note: assume raised heel):

1

$5.5^{\prime \prime}(\mathrm{R}-19,21)$ to a thickness of $6.75^{\prime \prime}(\mathrm{R}-22)$ :

$6.75^{\prime \prime}(\mathrm{R}-22)$ to a thickness of $9.5^{\prime \prime}(\mathrm{R}-30)$ :

$9.5^{\prime \prime}(\mathrm{R}-30)$ to a thickness of $12 "(\mathrm{R}-38)$ :

$12^{\prime \prime}(\mathrm{R}-38)$ to a thickness of $15^{\prime \prime}(\mathrm{R}-49)$ :

$15^{\prime \prime}(\mathrm{R}-49)$ to a thickness of 19" (R-60):

\section{Increased Framing Cost}

$+\$$

$+\$$

$+\$$

$+\$$

$+\$$

2. Assume: - Exterior walls 900 sq.ft. (8ft high $x 112.5$ linear feet)

- 12 windows at $3^{\prime} \times 4^{\prime}$ (168 linear feet)

- 2 doors at 3'0" x 6'8" (34 linear feet)

Assume easy access before the drywall is applied. What are the increased costs associated with going from $2 \times 4$ to $2 \times 6$ framing, including added costs for extension jambs on all windows and doors.

$+\$$

3. Assume: - 1/2" fiberboard is being replaced by insulative sheathing.

What are the costs of insulative sheathing with the following $R$ values:

R-3.6

$\$$

Such as $1 / 2$ in. Thermax Polyisocyanurate

R-4.5 \$

Such as 5/8 in. Thermax Polyisocyanurate

R-5.4

$\$$

Such as $3 / 4$ in. Thermax Polyisocyanurate
R-4 \$

Such as $1 / 2$ in. TUFF-R

R-5 \$

Such as $5 / 8$ in. TUFF-R

R-7.2 \$

Such as $1 \mathrm{in.}$ Thermax Polyisocyanurate 
R-8 \$

Such as 1 in. TUFF-R
R-10 \$

Such as $11 / 4$ in. TUFF-R

4. Assume: - 500 SF cathedral ceiling $\left(20^{\prime} \times 25^{\prime}\right)$

- 11 trusses at 24 " oc

- Ceiling slope of $3 / 12$ scissor truss within 6/12 pitch roof

Indicate increased framing costs associated with installing higher levels of insulation from a thickness of:

\section{Increased Framing Cost}

3.5 " (R-11,13,15) to a thickness of 5.5" (R-19,21):

$+\$$

$5.5^{\prime \prime}(\mathrm{R}-19,21)$ to a thickness of $6.75^{\prime \prime}(\mathrm{R}-22)$ :

$+\$$

$6.75^{\prime \prime}(\mathrm{R}-22)$ to a thickness of $9.5^{\prime \prime}(\mathrm{R}-30)$ :

$+\$$

9.5" (R-30) to a thickness of $12 "$ (R-38):

$+\$$

$12 "(\mathrm{R}-38)$ to a thickness of $15^{\prime \prime}(\mathrm{R}-49)$ :

$+\$$

$15^{\prime \prime}(\mathrm{R}-49)$ to a thickness of $19^{\prime \prime}(\mathrm{R}-60)$ :

$+\$$

5. Assume: - 8ft high of above-grade concrete block walls

- 900 SF of wall (112.5 $\times 8 \mathrm{ft} \mathrm{H})$

- 12 windows: 3 ' x 4' (168 LF)

- 2 doors at 3'0" x 6'8" (34 LF)

Assuming easy access before the drywall is applied, what are the framing costs associated with increasing insulation, including added costs for extension jambs on all windows and doors.

Above grade concrete block walls, interior application: expanded or extruded polystyrene:

Increased Cost

R-7.5 \$

R-15
Increased Cost

R-10 \$

R-19 \$ 

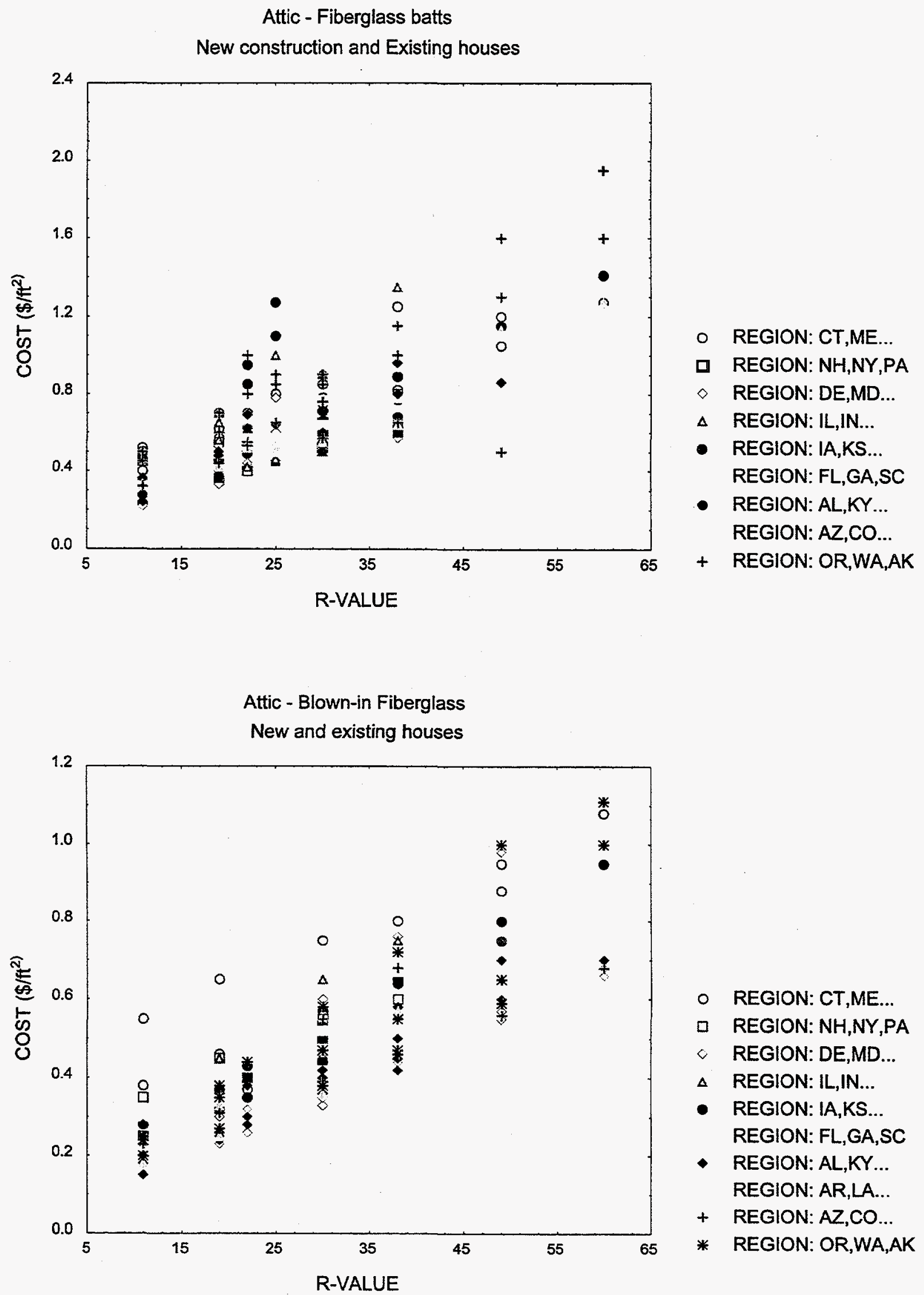


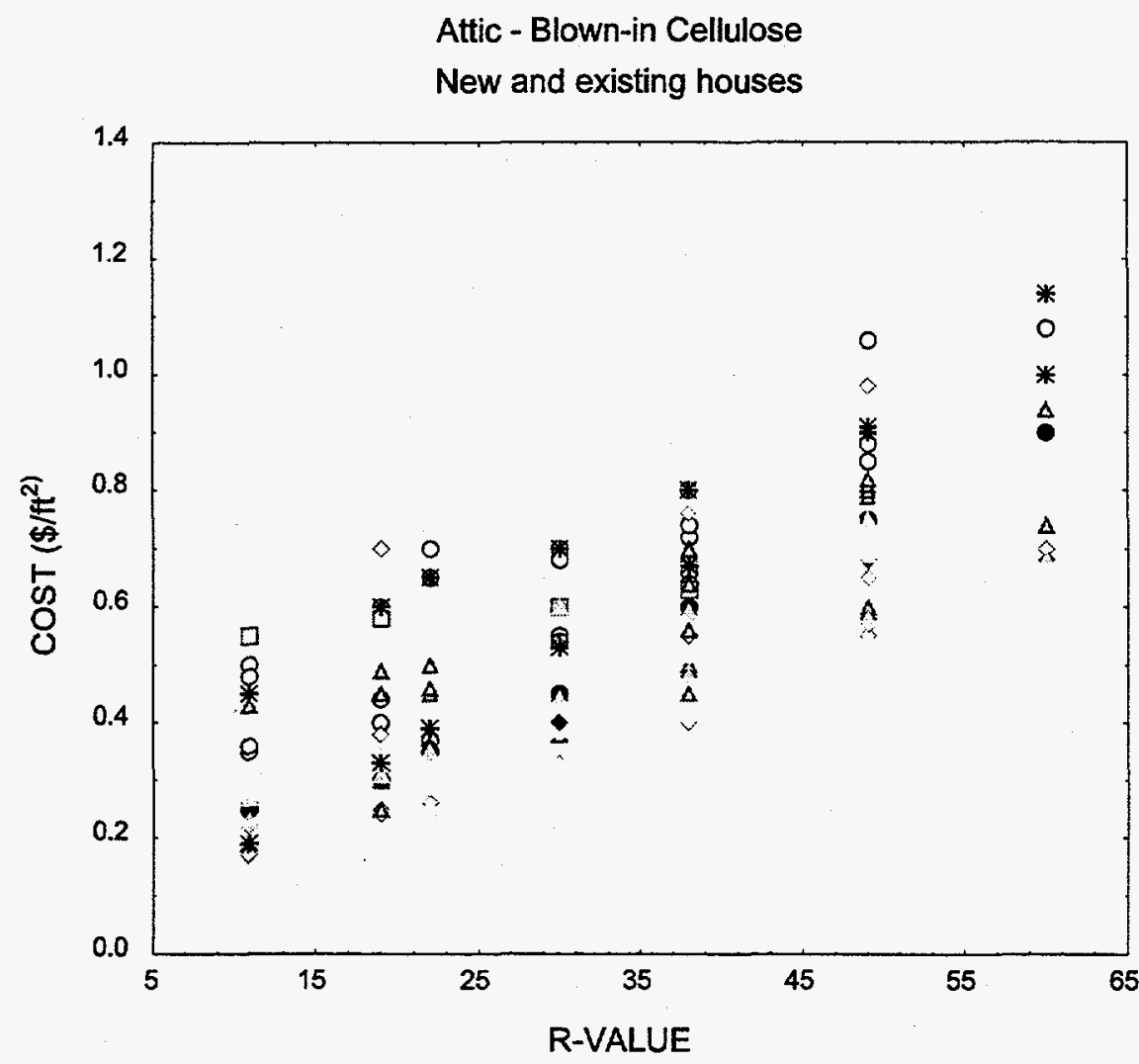

- REGION: CT,ME...

口 REGION: NH,NY,PA

\% REGION: DE,MD...

$\triangle$ REGION: IL,IN...

- REGION: IA,KS... REGION: FL,GA,SC

- REGION: AL,KY... REGION: AR,LA...

+ REGION: AZ,CO...

* REGION: OR,WA,AK

Attic - Blown-in Rockwool

New and existing houses

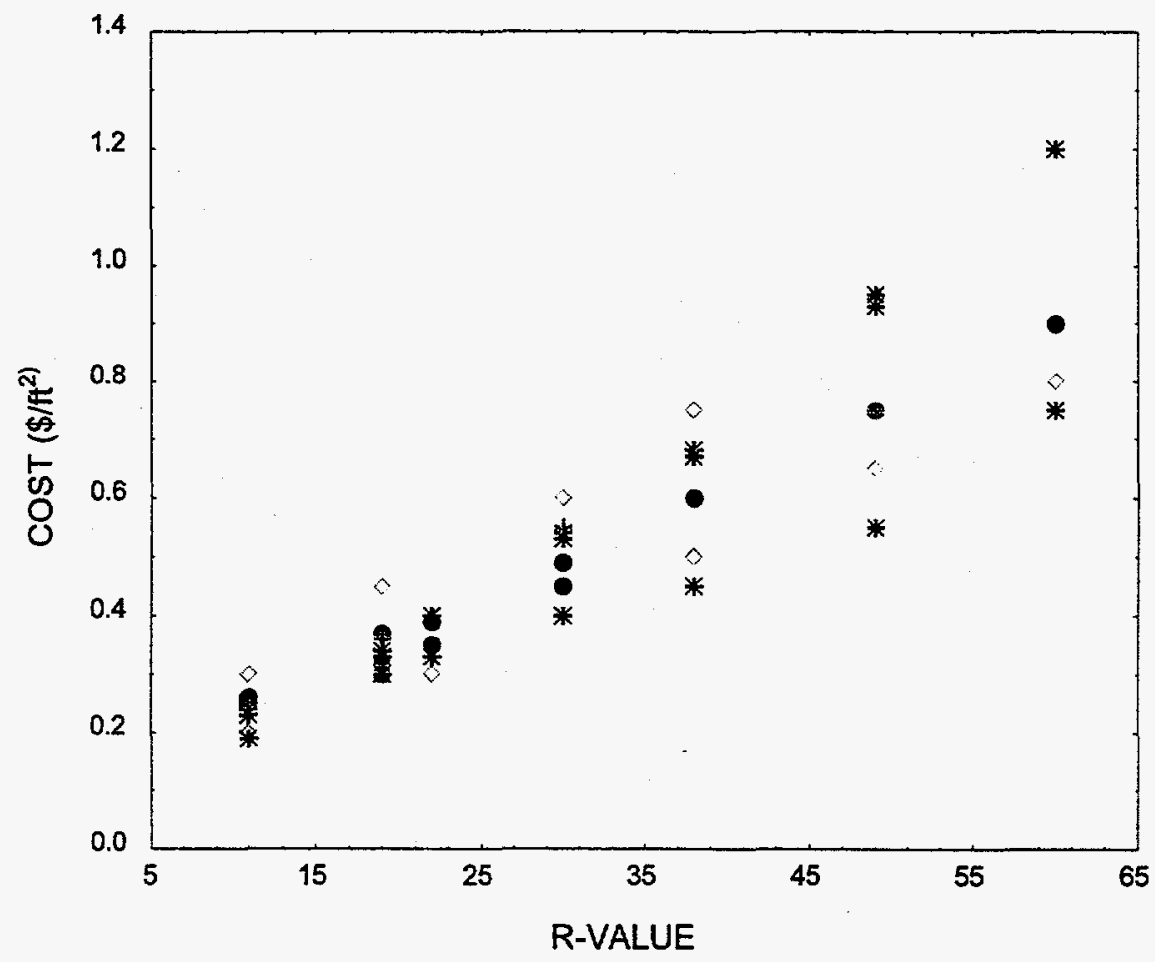

- REGION: CT,ME...

- REGION: NH,NY,PA

\& REGION: DE,MD...

$\triangle$ REGION: IL,IN...

- REGION: IA,KS... REGION: FL,GA,SC

- REGION: AL,KY... REGION: AR,LA...

+ REGION: AZ,CO...

* REGION: OR,WA,AK 
Cathedral ceiling - New houses

Fiberglass insulation only, does not include framing costs

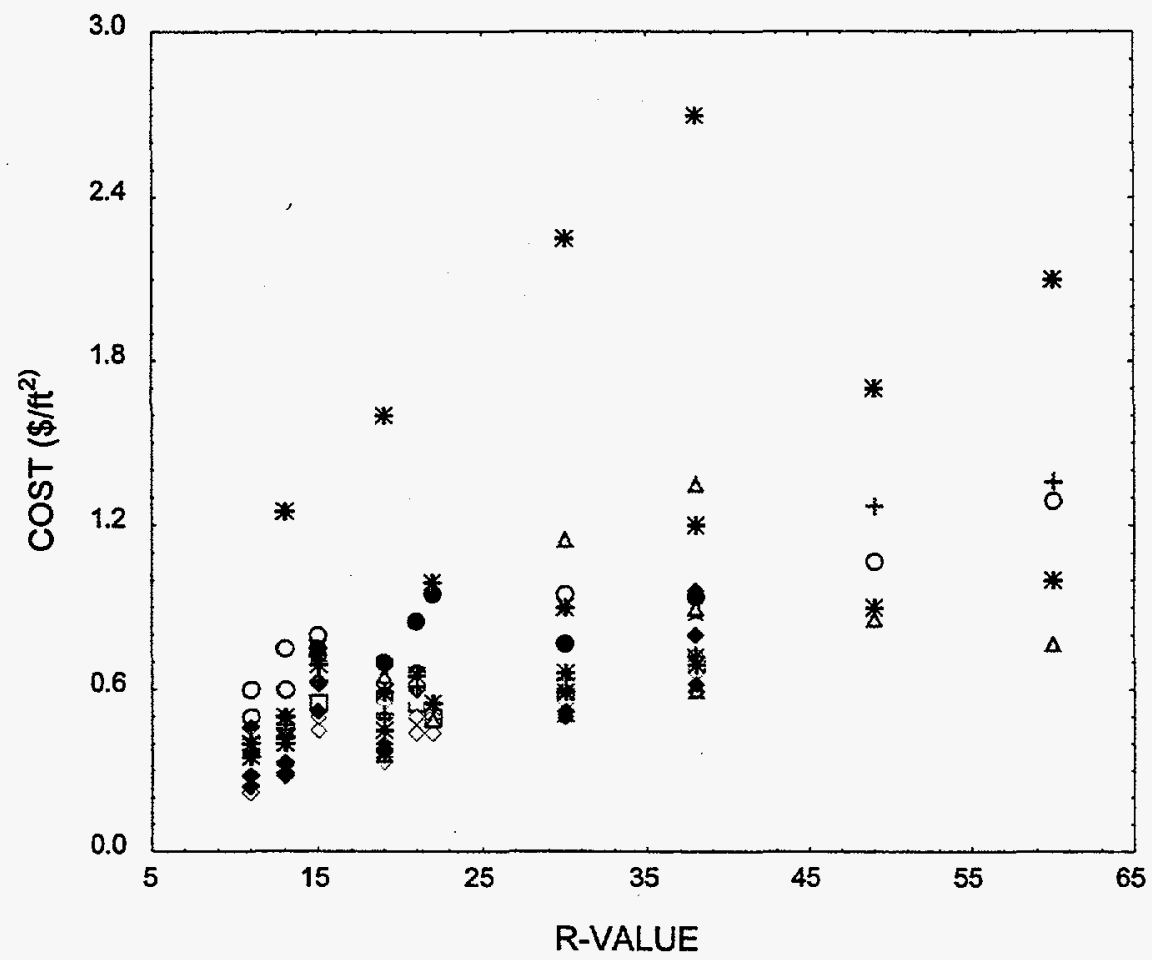

- REGION: CT,ME...

口 REGION: NH,NY,PA

\& REGION: DE,MD...

$\triangle$ REGION: IL,IN...

- REGION: IA,KS... REGION: FL, GA,SC

- REGION: AL,KY... REGION: AR,LA...

+ REGION: AZ,CO...

* REGION: OR,WA,AK

Floor over unconditioned space - Fiberglass batts

New construction and existing houses

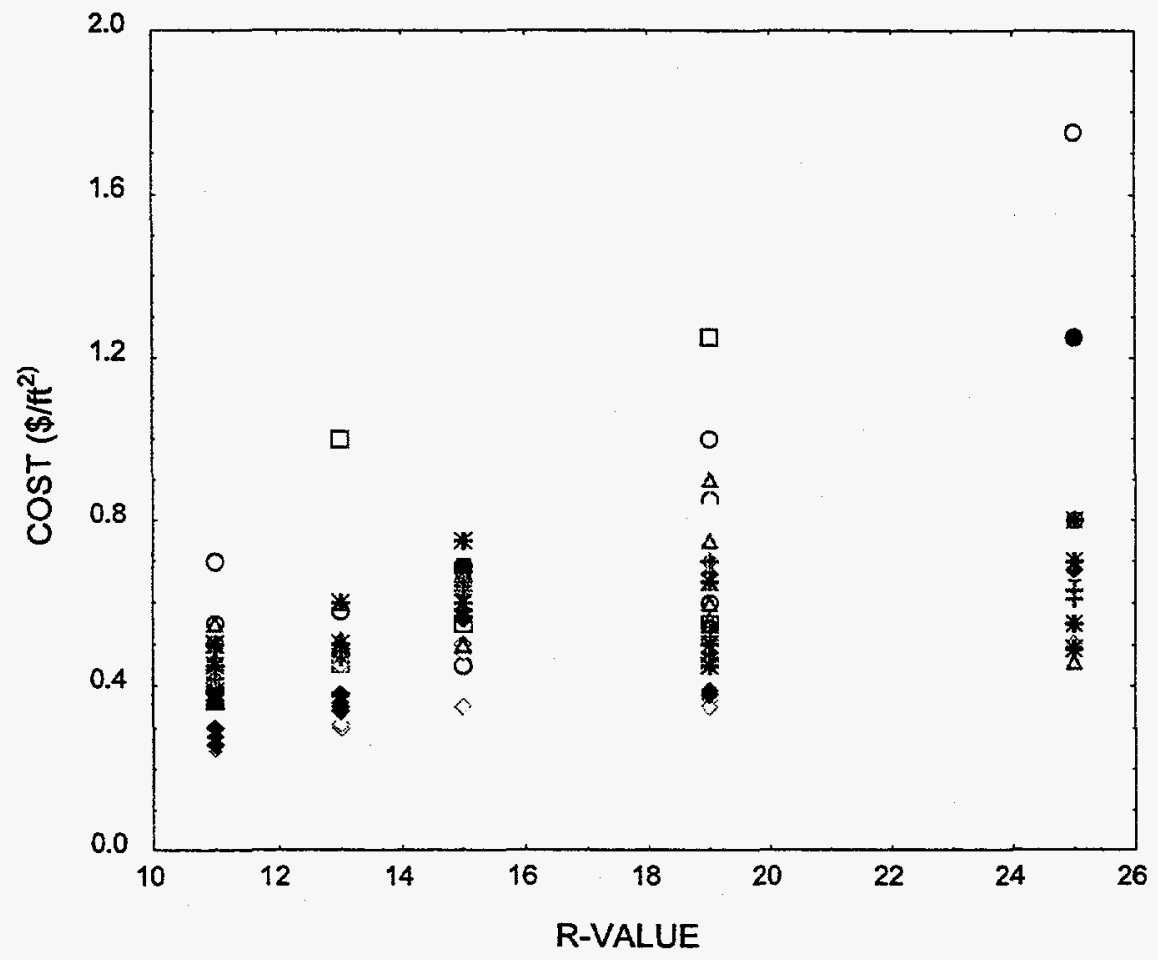

- REGION: CT,ME...

- REGION: NH,NY,PA

\& REGION: DE,MD...

$\triangle$ REGION: IL,IN...

- REGION: IA,KS... REGION: FL,GA,SC

- REGION: AL,KY... REGION: AR,LA...

+ REGION: AZ,CO...

* REGION: OR,WA,AK 


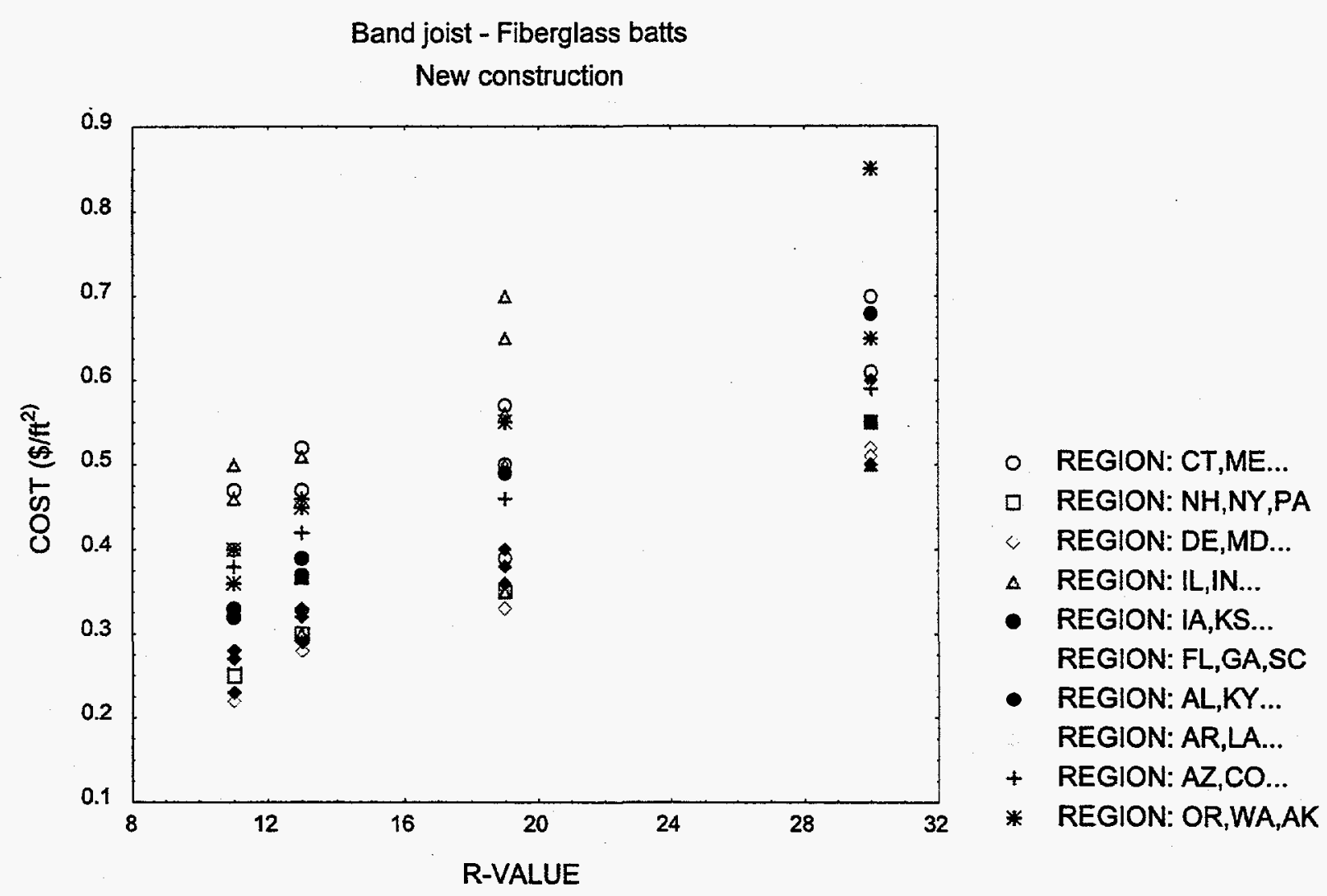

Exterior walls - blown-in insulation

Existing houses

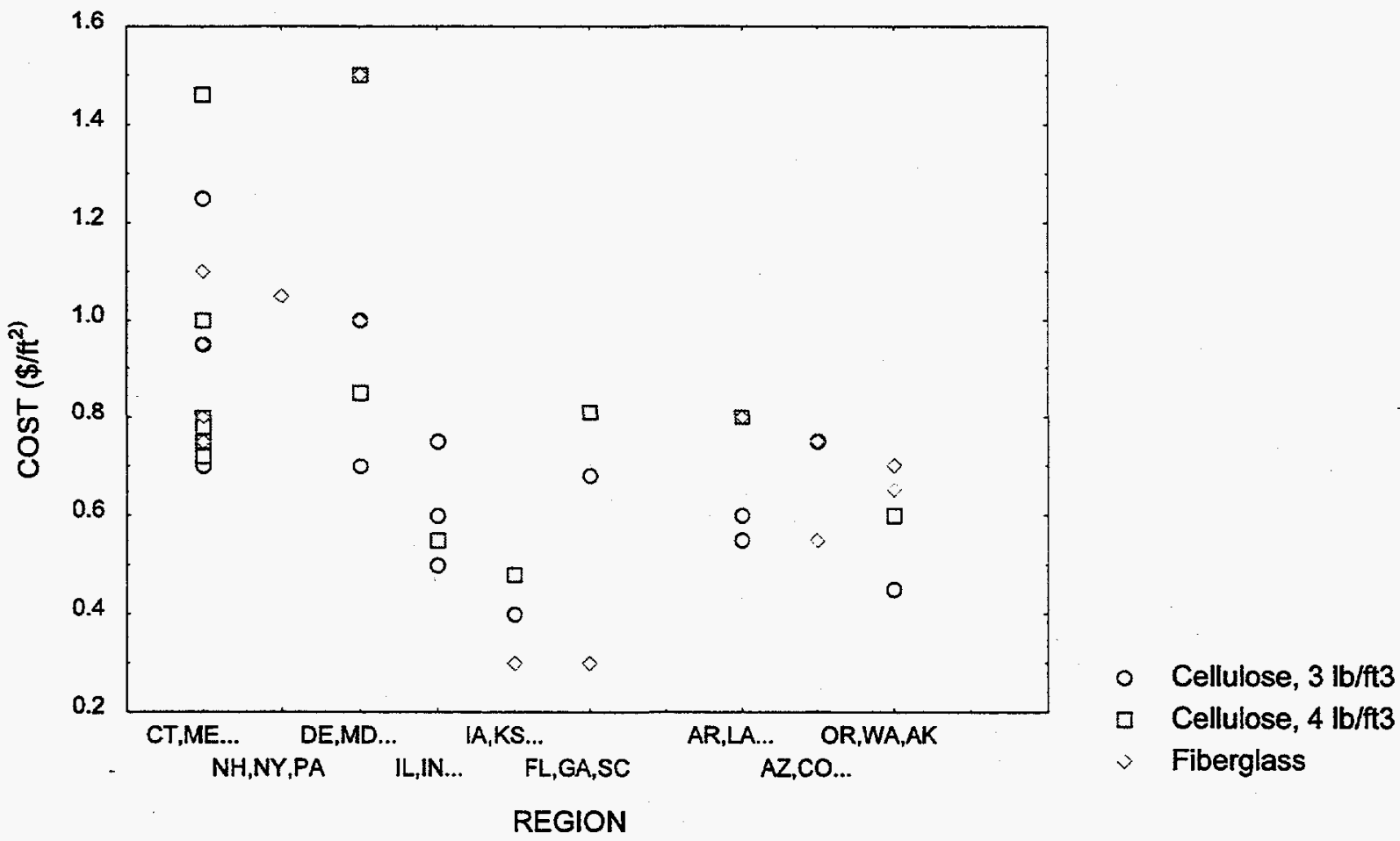

D-9 


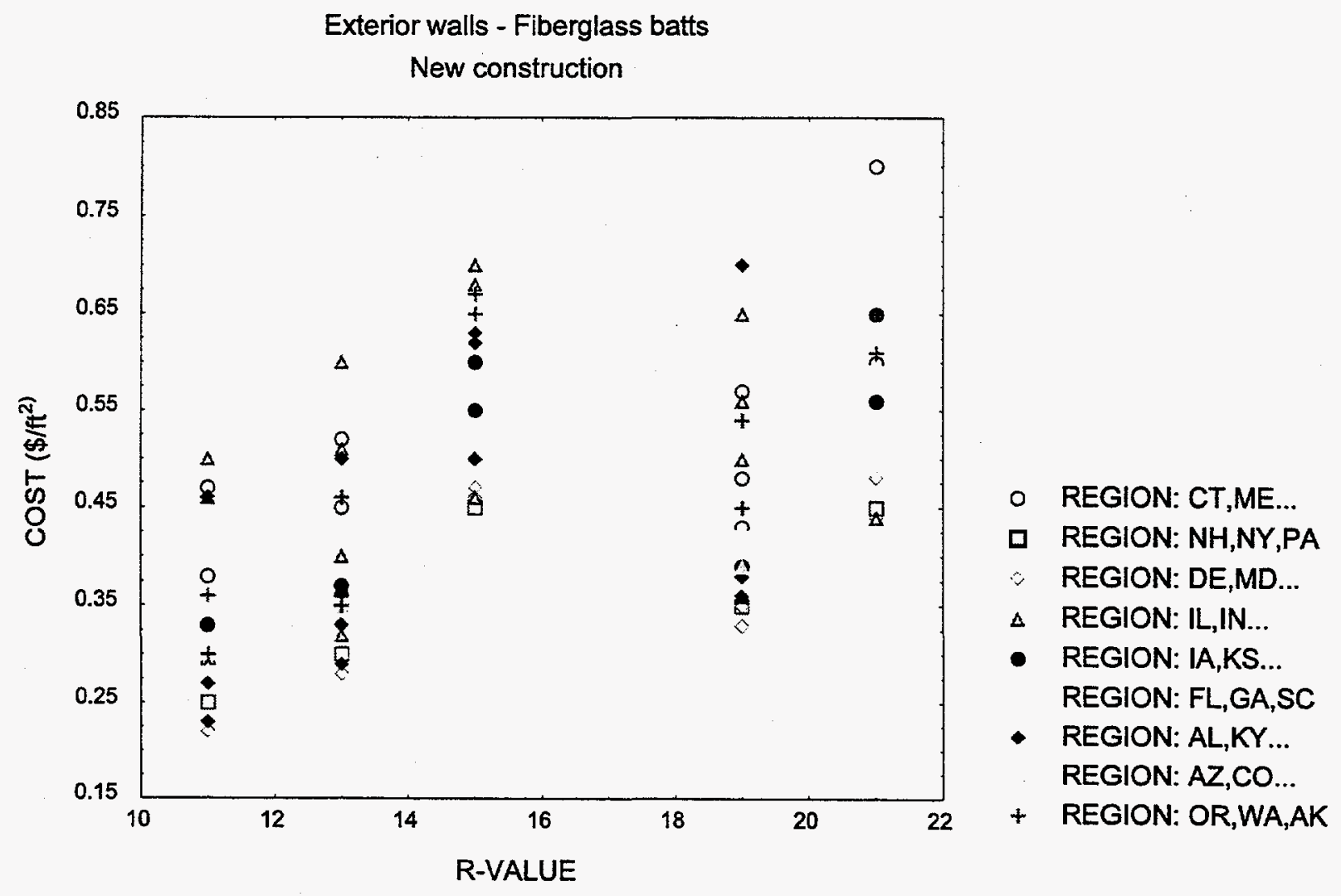

Exterior walls, sprayed cellulose

New construction

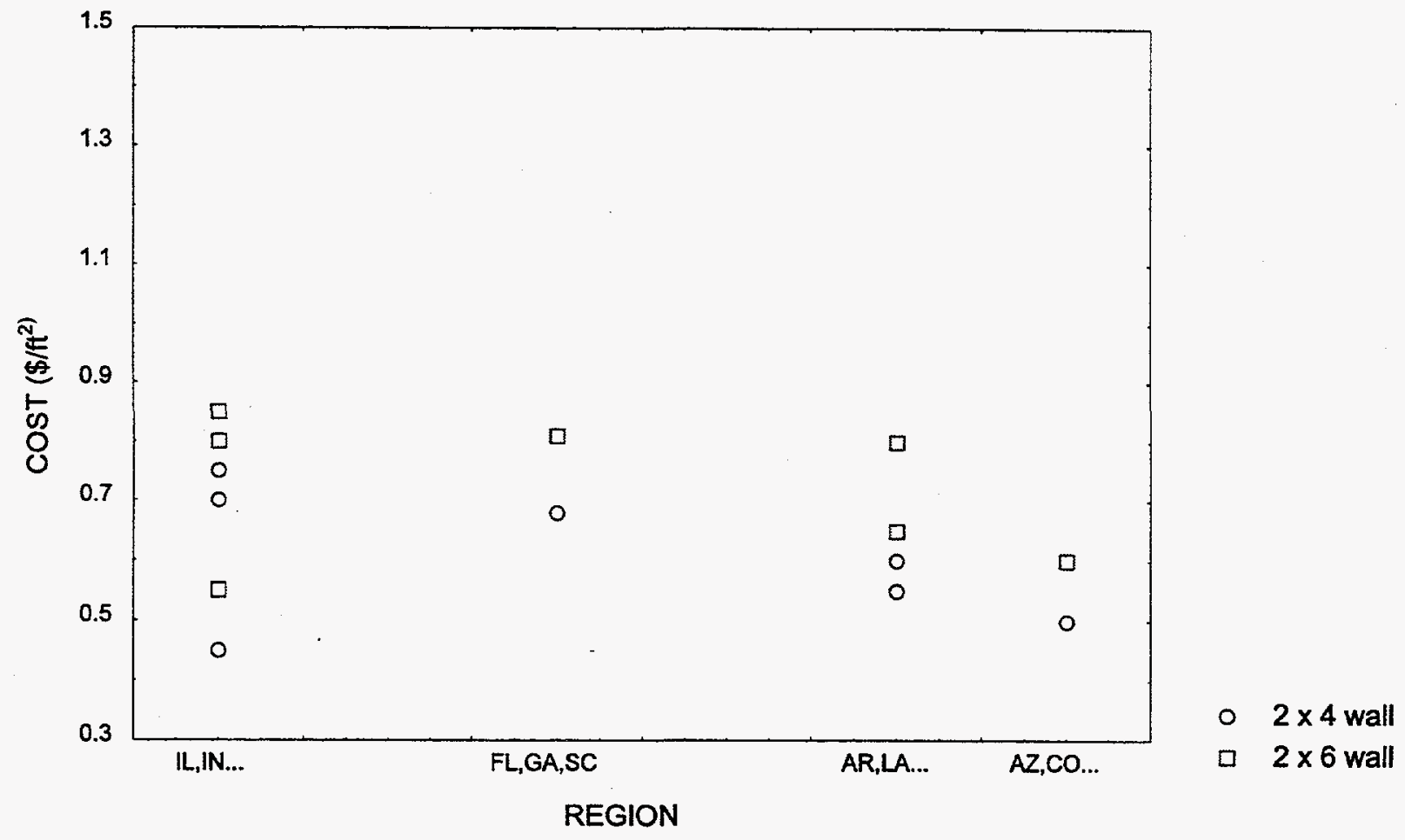

D-10 

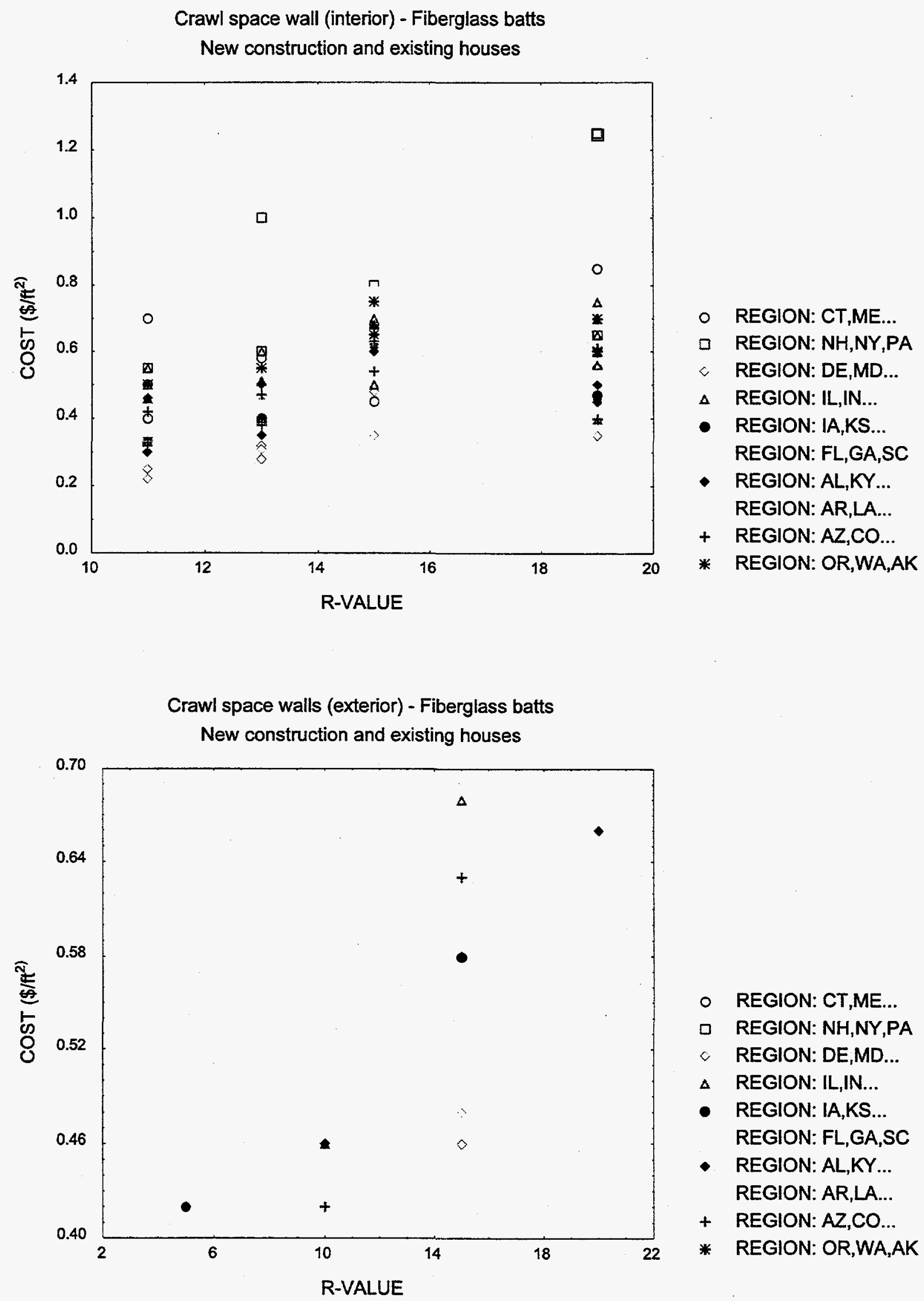


\section{Appendix E: Insulation Cost Multipliers and Energy Prices for Electricity, Natural Gas, and Fuel Oil ${ }^{13,14,15}$}

\begin{tabular}{|c|c|c|c|c|c|c|}
\hline $\begin{array}{l}\text { State } \\
\text { No. }\end{array}$ & State name & $\begin{array}{c}\text { Electricity } \\
(\boldsymbol{k} / \mathbf{k W h})\end{array}$ & $\begin{array}{c}\text { Distillate oil } \\
\text { (c/gal) }\end{array}$ & $\begin{array}{c}\text { Propane } \\
\text { (k/gal) }\end{array}$ & $\begin{array}{c}\text { Natural gas } \\
\left(\$ / 10^{3} \mathrm{ft}^{3}\right)\end{array}$ & $\begin{array}{l}\text { Insulation cost } \\
\text { multiplier" }\end{array}$ \\
\hline 1 & Alabama & 7 & 87.1 & 97.8 & 9.68 & 79 \\
\hline 2 & Alaska & 11.6 & 96.4 & 112.3 & 3.46 & 161 \\
\hline 3 & Arizona & 9.3 & 106.4 & 112.3 & 9.25 & 96 \\
\hline 4 & Arkansas & 8.1 & 87.1 & 97.8 & 7.03 & 77 \\
\hline 5 & California & 11.4 & 106.4 & 112.3 & 6.66 & 117 \\
\hline 6 & Colorado & 7.9 & 97.8 & 88.8 & 5.1 & 92 \\
\hline 7 & Connecticut & 12.3 & 103 & 127 & 10.58 & 107 \\
\hline 8 & Delaware & 9.1 & 103.1 & 116 & 9.02 & 101 \\
\hline 9 & District of Columbia & 7.2 & 120.9 & 116 & 9.86 & 91 \\
\hline 10 & Florida & 8.3 & 103.5 & 107.8 & 13.8 & 83 \\
\hline 11 & Georgia & 7.5 & 103.5 & 107.8 & 8.49 & 79 \\
\hline 12 & Hawaii & 14.6 & 106.4 & 112.3 & 21.05 & 121 \\
\hline 13 & Idaho & 5.3 & 97.8 & 88.8 & 5.59 & 99 \\
\hline 14. & Illinois & 11.8 & 92.4 & 83.7 & 5.93 & 103 \\
\hline 15 & Indiana & 7.8 & 96.7 & 83.7 & 6.33 & 94 \\
\hline 16 & Iowa & 8 & 96.8 & 83.7 & 6.74 & 86 \\
\hline 17 & Kansas & 7.9 & 96.8 & 83.7 & 6.52 & 86 \\
\hline 18 & Kentucky & 6 & 96.8 & 83.7 & 6.65 & 88 \\
\hline 19 & Louisiana & 8 & 87.1 & 97.8 & 8.3 & 81 \\
\hline 20 & Maine & 12.6 & 101 & 127 & 7.04 & 83 \\
\hline 21 & Maryland & 8.2 & 108.3 & 116 & 10.63 & 86 \\
\hline 22 & Massachusetts & 11.1 & 103 & 127 & 7.49 & 114 \\
\hline 23 & Michigan & 8.3 & 103 & 83.7 & 5.5 & 99 \\
\hline 24 & Minnesota & 7.2 & 97.6 & 83.7 & 5.47 & 108 \\
\hline 25 & Mississippi & 7.4 & 87.1 & 97.8 & 6.19 & 75 \\
\hline 26 & Missouri & 6.8 & 96.8 & 83.7 & 7.58 & 90 \\
\hline
\end{tabular}




\begin{tabular}{|c|c|c|c|c|c|c|}
\hline $\begin{array}{c}\text { State } \\
\text { No. }\end{array}$ & State name & $\begin{array}{c}\text { Electricity } \\
(\boldsymbol{d} / \mathbf{k W h})\end{array}$ & $\begin{array}{l}\text { Distillate oil } \\
\quad(\notin / g a l)\end{array}$ & $\begin{array}{c}\text { Propane } \\
\text { (c/gal) }\end{array}$ & $\begin{array}{c}\text { Natural gas } \\
\left(\$ / 10^{3} \mathrm{ft}^{3}\right)\end{array}$ & $\begin{array}{l}\text { Insulation cost } \\
\text { multiplier }\end{array}$ \\
\hline 27 & Montana & 6.3 & 97.8 & 88.8 & 5.56 & 96 \\
\hline 28 & Nebraska & 6 & 96.8 & 83.7 & 6.31 & 83 \\
\hline 29 & Nevada & 7.1 & 106.4 & 112.3 & 7.4 & 102 \\
\hline 30 & New Hampshire & 13.6 & 99.1 & 127 & 6.99 & 104 \\
\hline 31 & New Jersey & 12 & 105.5 & 116 & 8.05 & 109 \\
\hline 32 & New Mexico & 9.3 & 87.1 & 97.8 & 5.58 & 89 \\
\hline 33 & New York & 14 & 108.2 & 116 & 10.86 & 110 \\
\hline 34 & North Carolina & 8.7 & 103.5 & 107.8 & 9.9 & 74 \\
\hline 35 & North Dakota & 6.5 & 96.8 & 83.7 & 5.42 & 82 \\
\hline 36 & Ohio & 9.2 & 98.2 & 83.7 & 7.26 & 103 \\
\hline 37 & Oklahoma & 7.3 & 96.8 & 83.7 & 8.02 & 79 \\
\hline 38 & Oregon & 5.9 & 108.5 & 112.3 & 6.95 & 105 \\
\hline 39 & Pennsylvania & 10 & 99.5 & 116 & 8.59 & 102 \\
\hline 40 & Rhode Island & 11 & 104 & 127 & 9.9 & 106 \\
\hline 41 & South Carolina & 7.6 & 103.5 & 107.8 & 8.44 & 76 \\
\hline 42 & South Dakota & 7.5 & 96.8 & 83.7 & 5.94 & 80 \\
\hline 43 & Tennessee & 6.1 & 96.8 & 83.7 & 7.17 & 80 \\
\hline 44 & Texas & 8.1 & 87.1 & 97.8 & 6.97 & 79 \\
\hline 45 & Utah & 6.7 & 97.8 & 88.8 & 3.79 & 90 \\
\hline 46 & Vermont & 10.5 & 100.7 & 127 & 7.21 & 84 \\
\hline 47 & Virginia & 7.9 & 98.6 & 107.8 & 9.78 & 80 \\
\hline 48 & Washington & 5 & 116.3 & 112.3 & 6.86 & 110 \\
\hline 49 & West Virginia & 6.7 & 101.1 & 107.8 & 7.58 & 90 \\
\hline 50 & Wisconsin & 7.1 & 95.6 & 83.7 & 5.76 & 93 \\
\hline 51 & Wyoming & 6.6 & 97.8 & 88.8 & 7.07 & 86 \\
\hline
\end{tabular}

* normalized to 100 for the national average 


\section{Appendix F. Residential Energy Price Escalation Factors.}

Four regional energy price escalation tables are shown in this appendix. (The regional assignments for each zip code are shown in Appendix A.) These factors were taken from Ref. 12.

Table F.1 Relative energy prices for DOE region 1

\begin{tabular}{|c|c|c|c|c|c|c|c|c|c|c|c|c|c|c|c|}
\hline & \multicolumn{15}{|c|}{ Electricity $(\ell / \mathrm{kWh})$} \\
\hline Year & 1997 & 1998 & 1999 & 2000 & 2001 & 2002 & 2003 & 2004 & 2005 & 2006 & 2007 & 2008 & 2009 & 2010 & 2011 \\
\hline Factor & 0.99 & 1.00 & 1.00 & 1.00 & 1.00 & 1.00 & 1.00 & 1.00 & 1.01 & 1.02 & 1.01 & 1.01 & 1.02 & 1.03 & 1.03 \\
\hline Year & 2012 & 2013 & 2014 & 2015 & 2016 & 2017 & 2018 & 2019 & 2020 & 2021 & 2022 & 2023 & 2024 & 2025 & 2026 \\
\hline \multirow[t]{2}{*}{ Factor } & 1.03 & 1.03 & 1.04 & 1.05 & 1.05 & 1.05 & 1.05 & 1.05 & 1.05 & 1.05 & 1.05 & 1.05 & 1.05 & 1.05 & 1.05 \\
\hline & \multicolumn{15}{|c|}{ Distillate oil ( $\notin / g a l)$} \\
\hline Year & 1997 & 1998 & 1999 & 2000 & 2001 & 2002 & 2003 & 2004 & 2005 & 2006 & 2007 & 2008 & 2009 & 2010 & 2011 \\
\hline Factor & 1.02 & 1.05 & 1.06 & 1.09 & 1.11 & 1.12 & 1.12 & 1.13 & 1.14 & 1.16 & 1.16 & 1.17 & 1.18 & 1.18 & 1.18 \\
\hline Year & 2012 & 2013 & 2014 & 2015 & 2016 & 2017 & 2018 & 2019 & 2020 & 2021 & 2022 & 2023 & 2024 & 2025 & 2026 \\
\hline \multirow[t]{2}{*}{ Factor } & 1.19 & 1.19 & 1.20 & 1.21 & 1.21 & 1.22 & 1.23 & 1.24 & 1.25 & 1.26 & 1.27 & 1.28 & 1.29 & 1.30 & 1.31 \\
\hline & \multicolumn{15}{|c|}{ Propane ( $\notin / g a l)$} \\
\hline Year & 1997 & 1998 & 1999 & 2000 & 2001 & 2002 & 2003 & 2004 & 2005 & 2006 & 2007 & 2008 & 2009 & 2010 & 2011 \\
\hline Factor & 1.01 & 1.03 & 1.04 & 1.05 & 1.07 & 1.08 & 1.08 & 1.08 & 1.09 & 1.11 & 1.11 & 1.11 & 1.13 & 1.14 & 1.13 \\
\hline Year & 2012 & 2013 & 2014 & 2015 & 2016 & 2017 & 2018 & 2019 & 2020 & 2021 & 2022 & 2023 & 2024 & 2025 & 2026 \\
\hline \multirow[t]{2}{*}{ Factor } & 1.13 & 1.14 & 1.15 & 1.14 & 1.15 & 1.15 & 1.16 & 1.16 & 1.17 & 1.17 & 1.18 & 1.18 & 1.19 & 1.20 & 1.20 \\
\hline & \multicolumn{15}{|c|}{ Natural gas $\left(\$ / 1000 \mathrm{ft}^{3}\right)$} \\
\hline Year & 1997 & 1998 & 1999 & 2000 & 2001 & 2002 & 2003 & 2004 & 2005 & 2006 & 2007 & 2008 & 2009 & 2010 & 2011 \\
\hline Factor & 0.99 & 1.00 & 0.99 & 0.99 & 0.99 & 0.98 & 0.98 & 0.97 & 0.96 & 0.95 & 0.94 & 0.94 & 0.94 & 0.94 & 0.95 \\
\hline Year & 2012 & 2013 & 2014 & 2015 & 2016 & 2017 & 2018 & 2019 & 2020 & 2021 & 2022 & 2023 & 2024 & 2025 & 2026 \\
\hline Factor & 0.96 & 0.98 & 1.01 & 1.03 & 1.03 & 1.03 & 1.03 & 1.04 & 1.04 & 1.04 & 1.04 & 1.04 & 1.04 & 1.04 & 1.05 \\
\hline
\end{tabular}


Table F.2 Relative energy prices for DOE region 2

\begin{tabular}{|c|c|c|c|c|c|c|c|c|c|c|c|c|c|c|c|}
\hline & \multicolumn{15}{|c|}{ Electricity $(\varangle / \mathrm{kWh})$} \\
\hline Year & 1997 & 1998 & 1999 & 2000 & 2001 & 2002 & 2003 & 2004 & 2005 & 2006 & 2007 & 2008 & 2009 & 2010 & 2011 \\
\hline Factor & 0.99 & 0.99 & 0.99 & 0.98 & 0.97 & 0.97 & 0.97 & 0.96 & 0.96 & 0.96 & 0.97 & 0.97 & 0.97 & 0.96 & 0.95 \\
\hline Year & 2012 & 2013 & 2014 & 2015 & 2016 & 2017 & 2018 & 2019 & 2020 & 2021 & 2022 & 2023 & 2024 & 2025 & 2026 \\
\hline \multirow[t]{2}{*}{ Factor } & 0.93 & 0.93 & .094 & 0.95 & 0.95 & 0.95 & 0.95 & 0.95 & 0.95 & 0.95 & 0.95 & 0.95 & 0.95 & 0.95 & 0.95 \\
\hline & \multicolumn{15}{|c|}{ Distillate oil ( $\not / g a l)$} \\
\hline Year & 1997 & 1998 & 1999 & 2000 & 2001 & 2002 & 2003 & 2004 & 2005 & 2006 & 2007 & 2008 & 2009 & 2010 & 2011 \\
\hline Factor & 1.03 & 1.06 & 1.08 & 1.10 & 1.12 & 1.14 & 1.14 & 1.16 & 1.17 & 1.18 & 1.19 & 1.20 & 1.21 & 1.21 & 1.22 \\
\hline Year & 2012 & 2013 & 2014 & 2015 & 2016 & 2017 & 2018 & 2019 & 2020 & 2021 & 2022 & 2023 & 2024 & 2025 & 2026 \\
\hline \multirow[t]{2}{*}{ Factor } & 1.22 & 1.23 & 1.24 & 1.24 & 1.25 & 1.26 & 1.27 & 1.28 & 1.30 & 1.31 & 1.32 & 1.33 & 1.34 & 1.36 & 1.37 \\
\hline & \multicolumn{15}{|c|}{ Propane ( $\notin /$ gal) } \\
\hline Year & 1997 & 1998 & 1999 & 2000 & 2001 & 2002 & 2003 & 2004 & 2005 & 2006 & 2007 & 2008 & 2009 & 2010 & 2011 \\
\hline Factor & 1.02 & 1.05 & 1.07 & 1.10 & 1.13 & 1.14 & 1.15 & 1.15 & 1.16 & 1.19 & 1.18 & 1.18 & 1.20 & 1.20 & 1.20 \\
\hline Year & 2012 & 2013 & 2014 & 2015 & 2016 & 2017 & 2018 & 2019 & 2020 & 2021 & 2022 & 2023 & 2024 & 2025 & 2026 \\
\hline \multirow[t]{2}{*}{ Factor } & 1.20 & 1.20 & 1.22 & 1.22 & 1.22 & 1.23 & 1.24 & 1.25 & 1.25 & 1.26 & 1.27 & 1.28 & 1.28 & 1.29 & 1.30 \\
\hline & \multicolumn{15}{|c|}{ Natural gas $\left(\$ / 1000 \mathrm{ft}^{3}\right)$} \\
\hline Year & 1997 & 1998 & 1999 & 2000 & 2001 & 2002 & 2003 & 2004 & 2005 & 2006 & 2007 & 2008 & 2009 & 2010 & 2011 \\
\hline Factor & 1.00 & 1.01 & 1.01 & 1.02 & 1.02 & 1.02 & 1.02 & 1.01 & 1.01 & 1.00 & 1.00 & 1.00 & 1.00 & 1.00 & 1.01 \\
\hline Year & 2012 & 2013 & 2014 & 2015 & 2016 & 2017 & 2018 & 2019 & 2020 & 2021 & 2022 & 2023 & 2024 & 2025 & 2026 \\
\hline Factor & 1.03 & 1.05 & 1.08 & 1.10 & 1.10 & 1.10 & 1.11 & 1.11 & 1.12 & 1.12 & 1.13 & 1.13 & 1.14 & 1.14 & 1.15 \\
\hline
\end{tabular}


Table F.3 Relative energy prices for DOE region 3

\begin{tabular}{|c|c|c|c|c|c|c|c|c|c|c|c|c|c|c|c|}
\hline & \multicolumn{15}{|c|}{ Electricity $(\phi / \mathrm{kWh})$} \\
\hline Year & 1997 & 1998 & 1999 & 2000 & 2001 & 2002 & 2003 & 2004 & 2005 & 2006 & 2007 & 2008 & 2009 & 2010 & 2011 \\
\hline Factor & 0.99 & 0.98 & 0.98 & 0.98 & 0.98 & 0.98 & 0.98 & 0.98 & 0.98 & 0.98 & 0.98 & 0.98 & 0.98 & 0.97 & 0.97 \\
\hline Year & 2012 & 2013 & 2014 & 2015 & 2016 & 2017 & 2018 & 2019 & 2020 & 2021 & 2022 & 2023 & 2024 & 2025 & 2026 \\
\hline \multirow[t]{2}{*}{ Factor } & 0.96 & 0.95 & 0.96 & 0.97 & 0.97 & 0.97 & 0.97 & 0.97 & 0.97 & 0.97 & 0.97 & 0.97 & 0.97 & 0.97 & 0.97 \\
\hline & \multicolumn{15}{|c|}{ Distillate oil ( $(/ g a l)$} \\
\hline Year & 1997 & 1998 & 1999 & 2000 & 2001 & 2002 & 2003 & 2004 & 2005 & 2006 & 2007 & 2008 & 2009 & 2010 & 2011 \\
\hline Factor & 1.02 & 1.04 & 1.06 & 1.09 & 1.10 & 1.11 & 1.12 & 1.13 & 1.14 & 1.16 & 1.16 & 1.17 & 1.18 & 1.18 & 1.18 \\
\hline Year & 2012 & 2013 & 2014 & 2015 & 2016 & 2017 & 2018 & 2019 & 2020 & 2021 & 2022 & 2023 & 2024 & 2025 & 2026 \\
\hline \multirow[t]{2}{*}{ Factor } & 1.19 & 1.19 & 1.20 & 1.21 & 1.21 & 1.22 & 1.23 & 1.24 & 1.25 & 1.27 & 1.28 & 1.29 & 1.30 & 1.31 & 1.32 \\
\hline & \multicolumn{15}{|c|}{ Propane ( $(/ \mathrm{gal})$} \\
\hline Year & 1997 & 1998 & 1999 & 2000 & 2001 & 2002 & 2003 & 2004 & 2005 & 2006 & 2007 & 2008 & 2009 & 2010 & 2011 \\
\hline Factor & 1.02 & 1.04 & 1.06 & 1.08 & 1.10 & 1.12 & 1.12 & 1.12 & 1.13 & 1.15 & 1.15 & 1.14 & 1.16 & 1.16 & 1.16 \\
\hline Year & 2012 & 2013 & 2014 & 2015 & 2016 & 2017 & 2018 & 2019 & 2020 & 2021 & 2022 & 2023 & 2024 & 2025 & 2026 \\
\hline \multirow[t]{2}{*}{ Factor } & 1.16 & 1.16 & 1.18 & 1.17 & 1.18 & 1.18 & 1.19 & 1.19 & 1.20 & 1.21 & 1.21 & 1.22 & 1.22 & 1.23 & 1.24 \\
\hline & \multicolumn{15}{|c|}{ Natural gas $\left(\$ / 1000 \mathrm{ft}^{3}\right)$} \\
\hline Year & 1997 & 1998 & 1999 & 2000 & 2001 & 2002 & 2003 & 2004 & 2005 & 2006 & 2007 & 2008 & 2009 & 2010 & 2011 \\
\hline Factor & 1.02 & 1.02 & 1.02 & 1.02 & 1.02 & 1.02 & 1.01 & 1.01 & 1.01 & 1.00 & 1.00 & 1.00 & 1.01 & 1.01 & 1.03 \\
\hline Year & 2012 & 2013 & 2014 & 2015 & 2016 & 2017 & 2018 & 2019 & 2020 & 2021 & 2022 & 2023 & 2024 & 2025 & 2026 \\
\hline Factor & 1.04 & 1.05 & 1.08 & 1.11 & 1.11 & 1.11 & 1.11 & 1.12 & 1.12 & 1.12 & 1.13 & 1.13 & 1.13 & 1.14 & 1.14 \\
\hline
\end{tabular}


Table F.4 Relative energy prices for DOE region 4

\begin{tabular}{|c|c|c|c|c|c|c|c|c|c|c|c|c|c|c|c|}
\hline & \multicolumn{15}{|c|}{ Electricity $(\mathrm{c} / \mathrm{kWh})$} \\
\hline Year & 1997 & 1998 & 1999 & 2000 & 2001 & 2002 & 2003 & 2004 & 2005 & 2006 & 2007 & 2008 & 2009 & 2010 & 2011 \\
\hline Factor & 1.00 & 1.00 & 1.02 & 1.03 & 1.04 & 1.05 & 1.06 & 1.06 & 1.06 & 1.06 & $1: 06$ & 1.06 & 1.06 & 1.06 & 1.07 \\
\hline Year & 2012 & 2013 & 2014 & 2015 & 2016 & 2017 & 2018 & 2019 & 2020 & 2021 & 2022 & 2023 & 2024 & 2025 & 2026 \\
\hline \multirow[t]{2}{*}{ Factor } & 1.07 & 1.07 & 1.09 & 1.10 & 1.10 & 1.10 & 1.10 & 1.10 & 1.10 & 1.10 & 1.10 & 1.10 & 1.10 & 1.10 & 1.10 \\
\hline & \multicolumn{15}{|c|}{ Distillate oil ( $\not / g a l)$} \\
\hline Year & 1997 & 1998 & 1999 & 2000 & 2001 & 2002 & 2003 & 2004 & 2005 & 2006 & 2007 & 2008 & 2009 & 2010 & 2011 \\
\hline Factor & 1.04 & 1.06 & 1.08 & 1.11 & 1.13 & 1.15 & 1.16 & 1.16 & 1.18 & 1.20 & 1.20 & 1.21 & 1.24 & 1.25 & 1.23 \\
\hline Year & 2012 & 2013 & 2014 & 2015 & 2016 & 2017 & 2018 & 2019 & 2020 & 2021 & 2022 & 2023 & 2024 & 2025 & 2026 \\
\hline \multirow[t]{2}{*}{ Factor } & 1.24 & 1.27 & 1.28 & 1.26 & 1.27 & 1.28 & 1.30 & 1.31 & 1.32 & 1.33 & 1.34 & 1.35 & 1.36 & 1.37 & 1.39 \\
\hline & \multicolumn{15}{|c|}{ Propane ( $\phi / g a l)$} \\
\hline Year & 1997 & 1998 & 1999 & 2000 & 2001 & 2002 & 2003 & 2004 & 2005 & 2006 & 2007 & 2008 & 2009 & 2010 & 2011 \\
\hline Factor & 1.02 & 1.03 & 1.05 & 1.04 & 1.06 & 1.06 & 1.07 & 1.07 & 1.09 & 1.10 & 1.10 & 1.11 & 1.12 & 1.13 & 1.14 \\
\hline Year & 2012 & 2013 & 2014 & 2015 & 2016 & 2017 & 2018 & 2019 & 2020 & 2021 & 2022 & 2023 & 2024 & 2025 & 2026 \\
\hline \multirow[t]{2}{*}{ Factor } & 1.15 & 1.16 & 1.16 & 1.17 & 1.18 & 1.18 & 1.19 & 1.20 & 1.20 & 1.21 & 1.22 & 1.22 & 1.23 & 1.23 & 1.24 \\
\hline & \multicolumn{15}{|c|}{ Natural gas $\left(\$ / 1000 \mathrm{ft}^{3}\right)$} \\
\hline Year & 1997 & 1998 & 1999 & 2000 & 2001 & 2002 & 2003 & 2004 & 2005 & 2006 & 2007 & 2008 & 2009 & 2010 & 2011 \\
\hline Factor & 1.01 & 1.02 & 1.01 & 1.02 & 1.01 & 1.01 & 1.01 & 0.99 & 0.98 & 0.97 & 0.97 & 0.96 & 0.97 & 0.97 & 0.98 \\
\hline Year & 2012 & 2013 & 2014 & 2015 & 2016 & 2017 & 2018 & 2019 & 2020 & 2021 & 2022 & 2023 & 2024 & 2025 & 2026 \\
\hline Factor & 0.98 & 0.99 & 1.00 & 1.00 & 1.01 & 1.01 & 1.01 & 1.02 & 1.02 & 1.03 & 1.03 & 1.04 & 1.04 & 1.04 & 1.05 \\
\hline
\end{tabular}




\section{Appendix G. Net Savings for Wall Insulation Options.}

The figures in this appendix show the range of savings calculated for several possible combinations of wall sheathing and wall cavity insulation for new homes with wood or metal frames. A separate data value was calculated using the ZIP-Code computer program for each zip code and for each heating system type. The results were then summarized according to the new construction Insulation Group assignment. For this analysis, the insulative sheathing was assumed to be placed on top of a wooden sheathing.

The R-Labels shown on each figure can be understood using the following translation table. The R-values shown in this table are for the insulation products only. They do not reflect the remainder of the wall assembly, which was however considered in the overall U-values used by the ZIP-Code computer analysis (see Appendix $\mathrm{C}$ for the details of the U-value calculations). Combinations of sheathing and cavity insulation other than those shown in this table are available. However, the combinations shown in this table offered more thermal resistance for less expense when compared to some of these other possible choices.

Table I.1. Definitions of "R-Label" shown on Figures in this appendix

\begin{tabular}{|c|c|c|}
\hline R-Label & Insulative sheathing R-value & Cavity insulation R-value \\
\hline 11 & 0 & 11 \\
\hline 13 & 0 & 13 \\
\hline 15 & 0 & 15 \\
\hline 2501 & 2.5 (or $1 / 2$ in. of R-5 per inch sheathing) & 0 \\
\hline 2511 & 2.5 (or $1 / 2$ in. of R-5 per inch sheathing) & 11 \\
\hline 2513 & 2.5 (or $1 / 2$ in. of R-5 per inch sheathing) & 13 \\
\hline 5001 & 5 (or 1 in. of R-5 per inch sheathing) & 0 \\
\hline 5011 & 5 (or 1 in. of R-5 per inch sheathing) & 11 \\
\hline 5013 & 5 (or 1 in. of R-5 per inch sheathing) & 13 \\
\hline 5015 & 5 (or 1 in. of R-5 per inch sheathing) & 15 \\
\hline 5019 & 5 (or 1 in. of R-5 per inch sheathing) & 19 \\
\hline 5021 & 5 (or 1 in. of R-5 per inch sheathing) & 21 \\
\hline 7011 & 7 (or 1 in. of R-7 per inch sheathing) & 11 \\
\hline 7013 & 7 (or 1 in. of R-7 per inch sheathing) & 13 \\
\hline 7015 & 7 (or 1 in. of R-7 per inch sheathing) & 15 \\
\hline 7019 & 7 (or 1 in. of R-7 per inch sheathing) & 19 \\
\hline 7021 & 7 (or 1 in. of R-7 per inch sheathing) & 21 \\
\hline
\end{tabular}




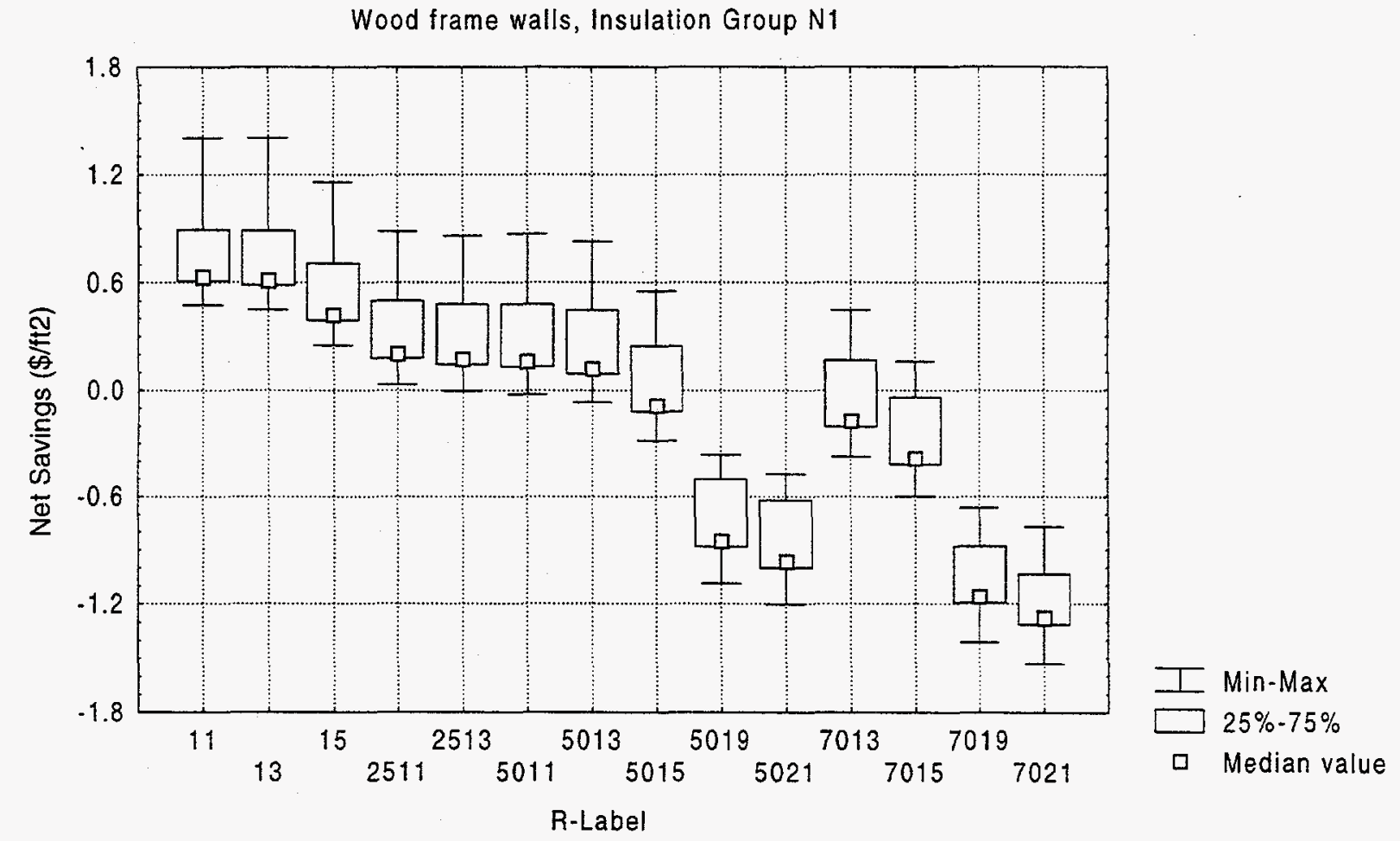

Wood frame walls, Insulation Group N2

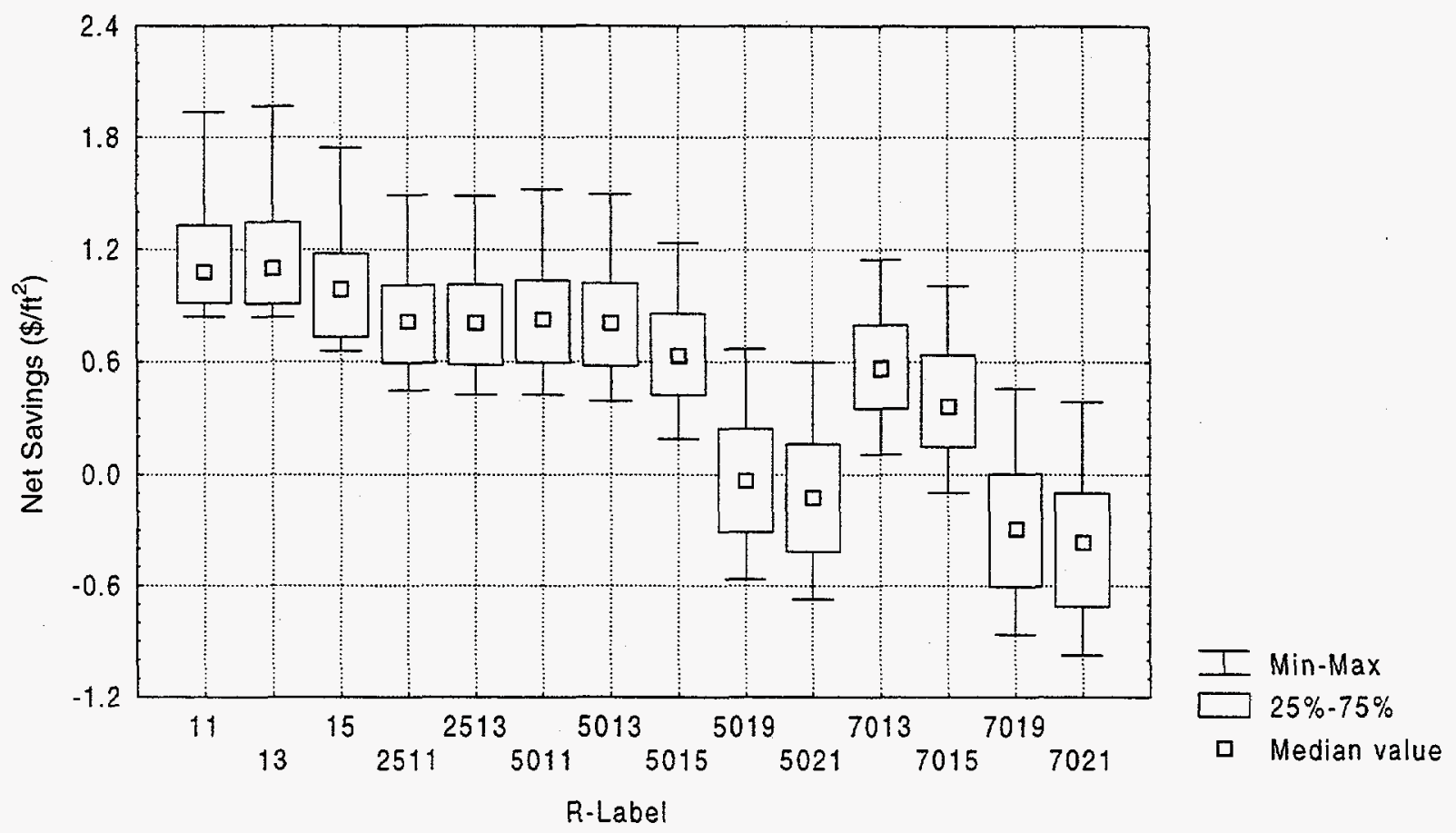

G-2 
Wood frame walls, Insulation Group N3

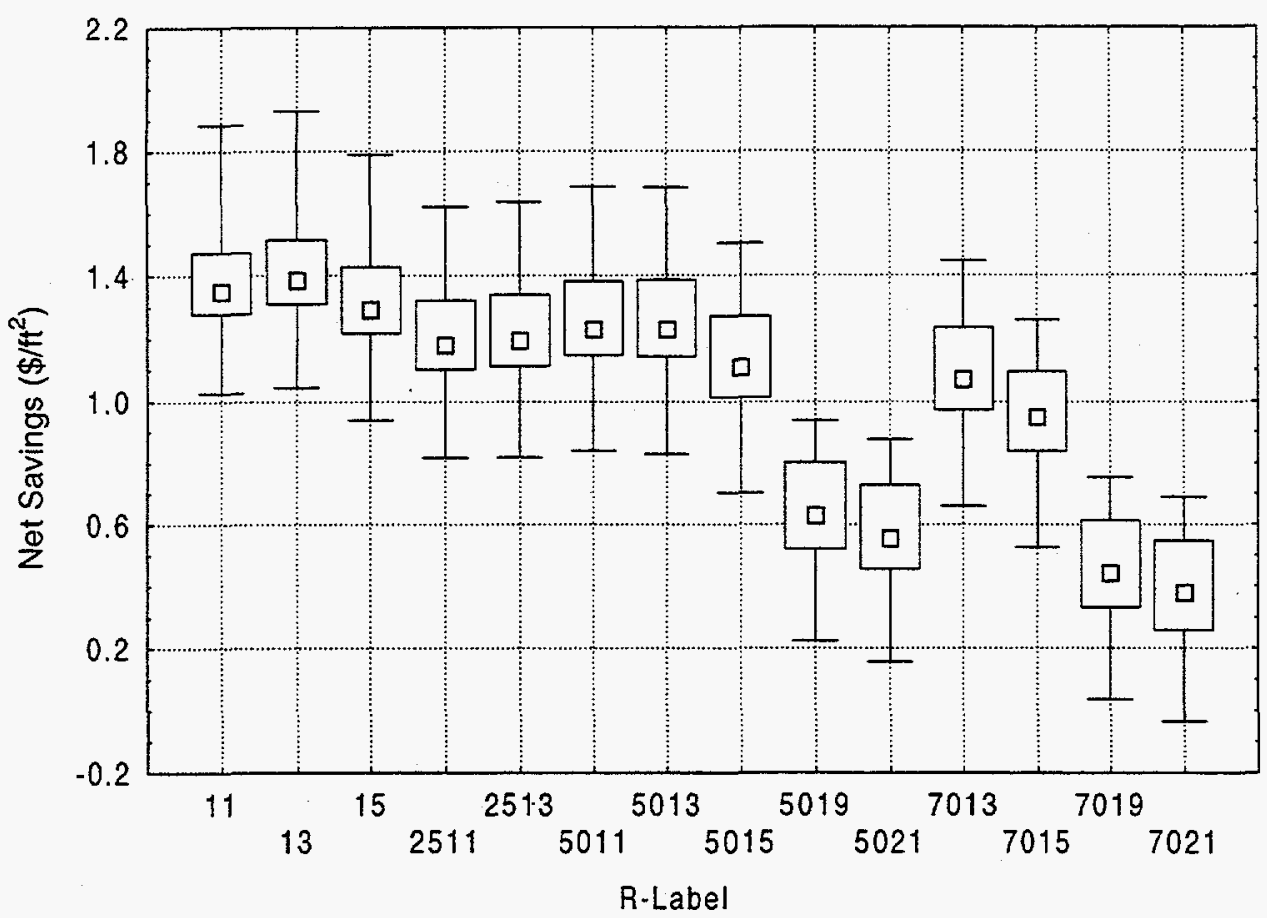

I Min-Max $25 \% \cdot 75 \%$

․ Median value

Wood frame walls, Insulation Group N4

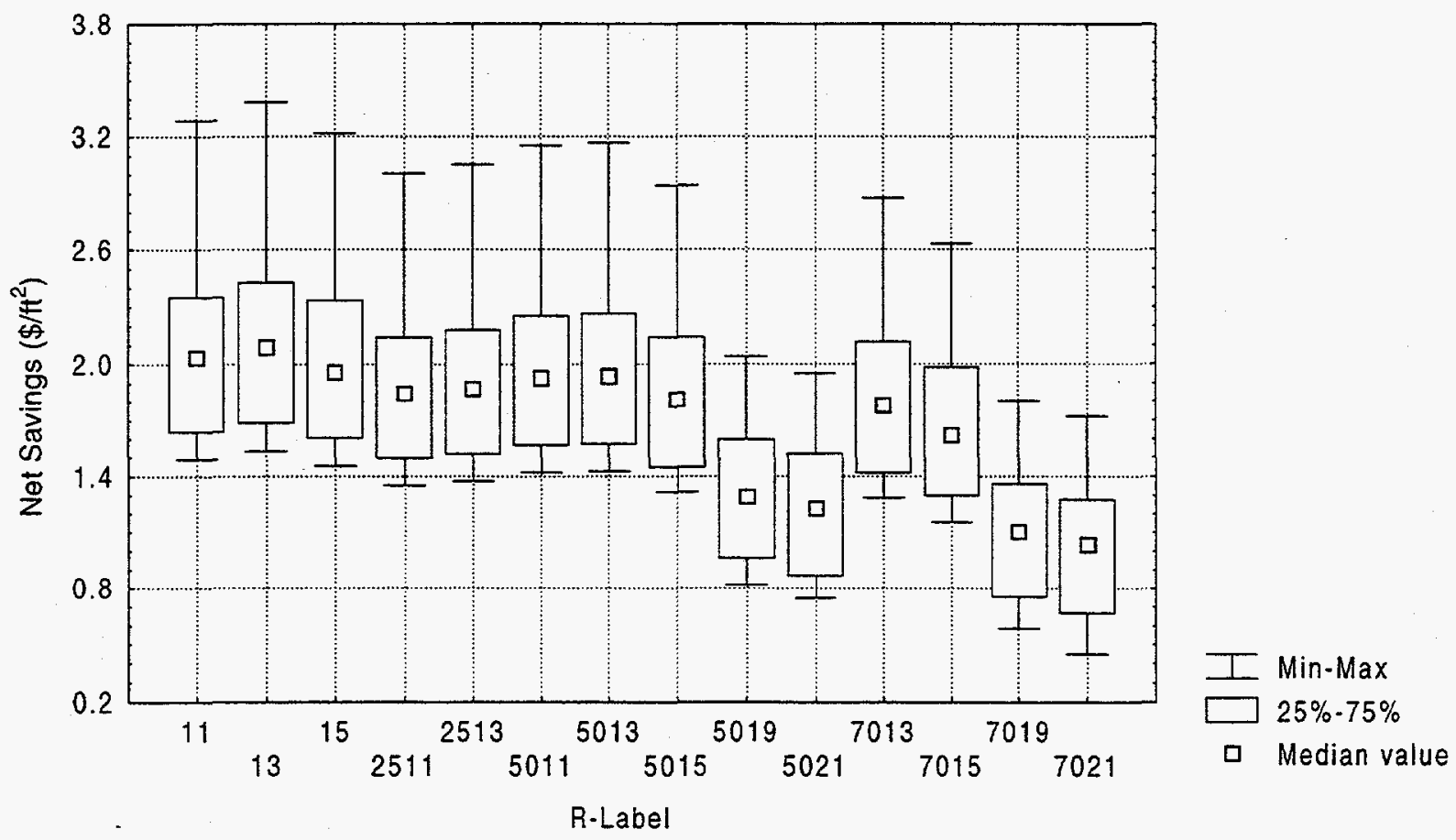


Wood frame walls, Insulation Group N5

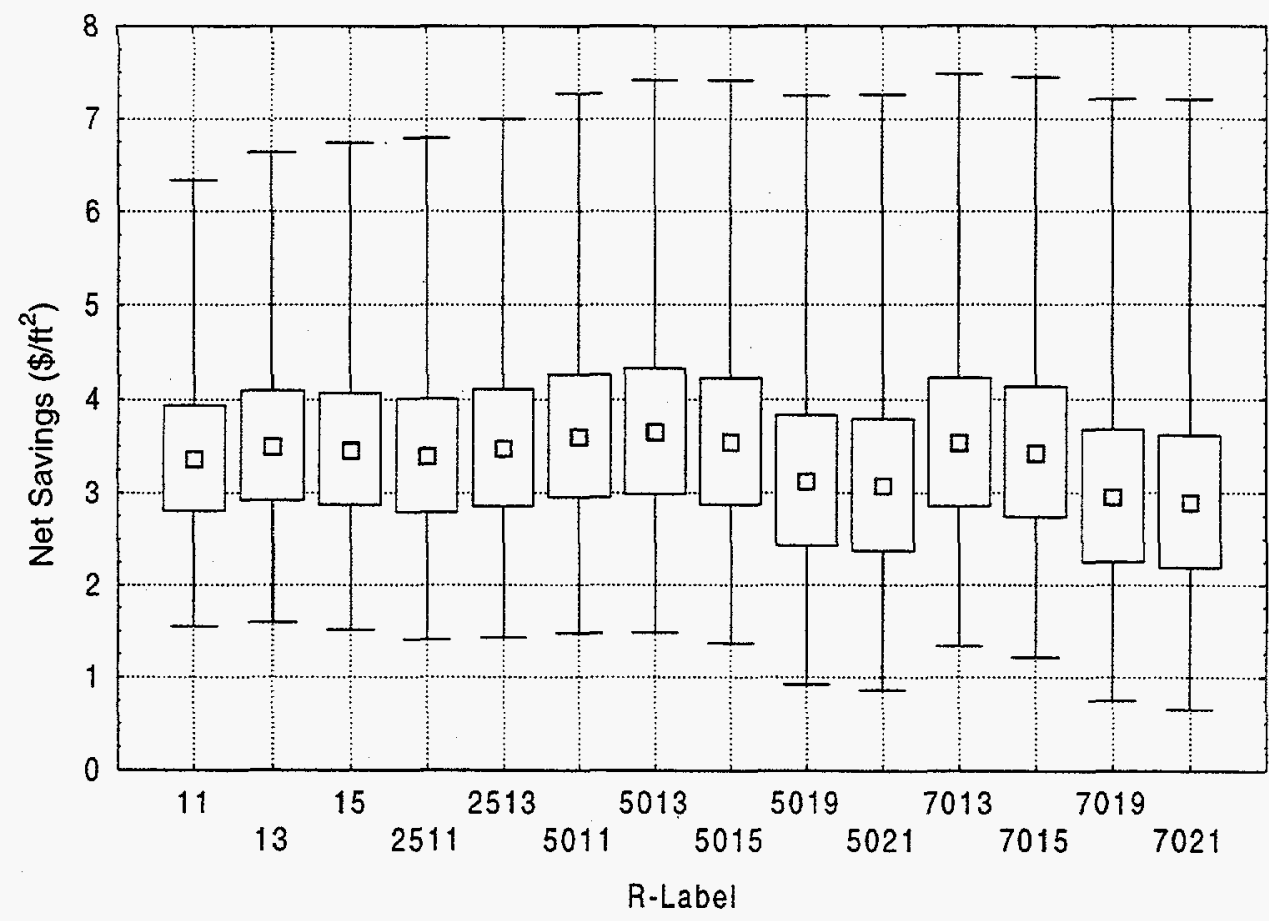

I Min-Max

口 Median value

Wood frame walls, Insulation Group N6

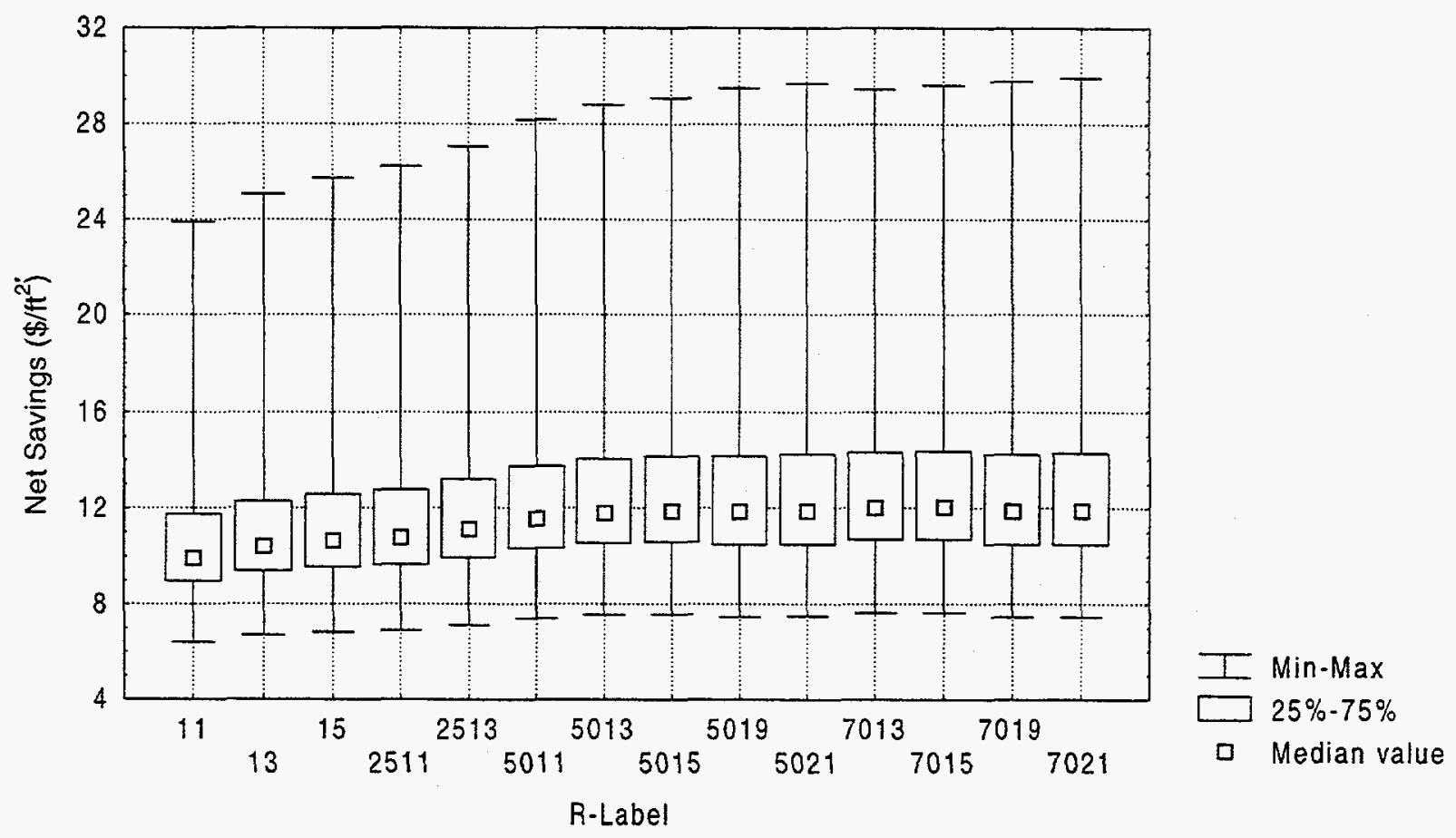




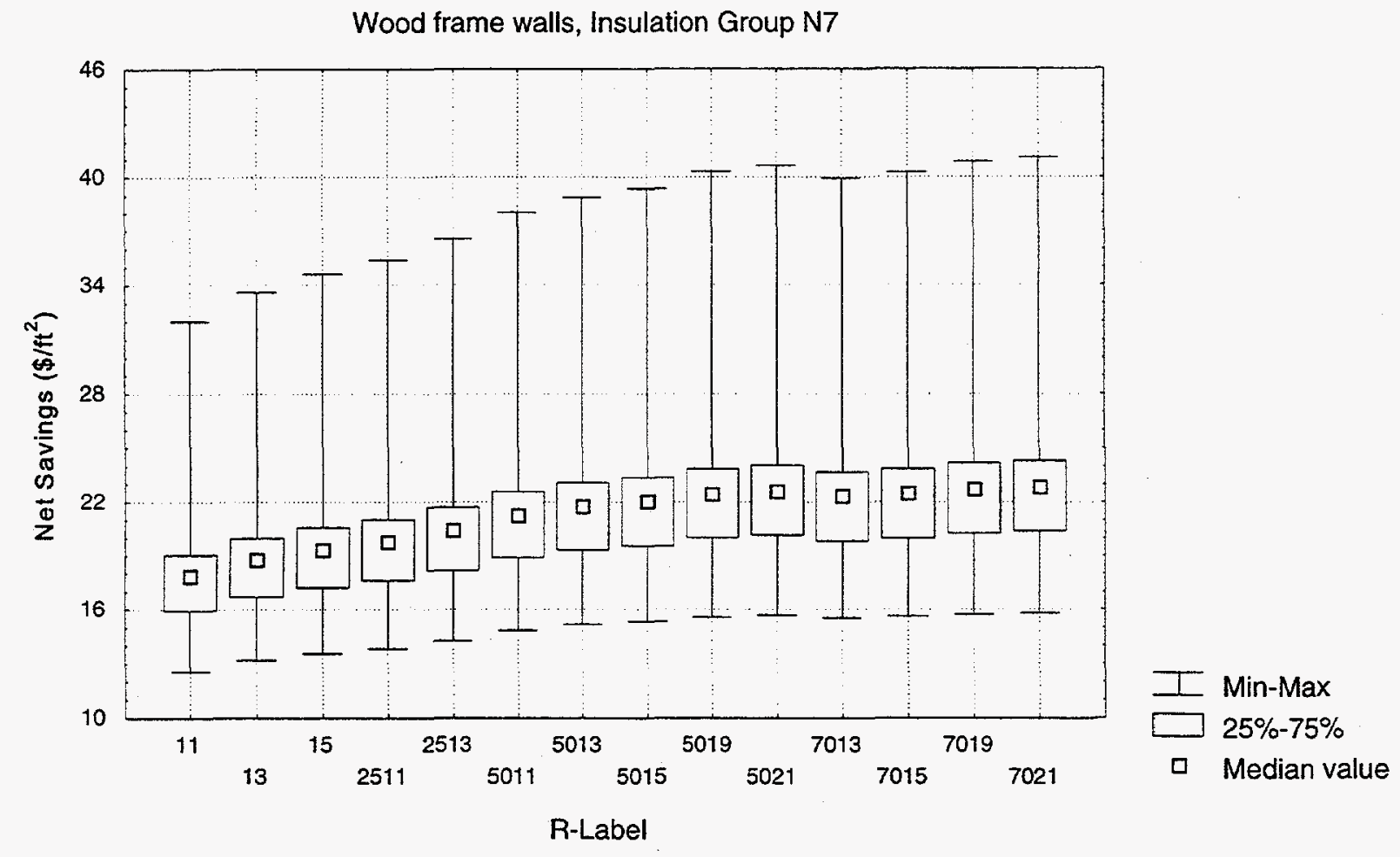

Metal frame walls, Insulation Group N1

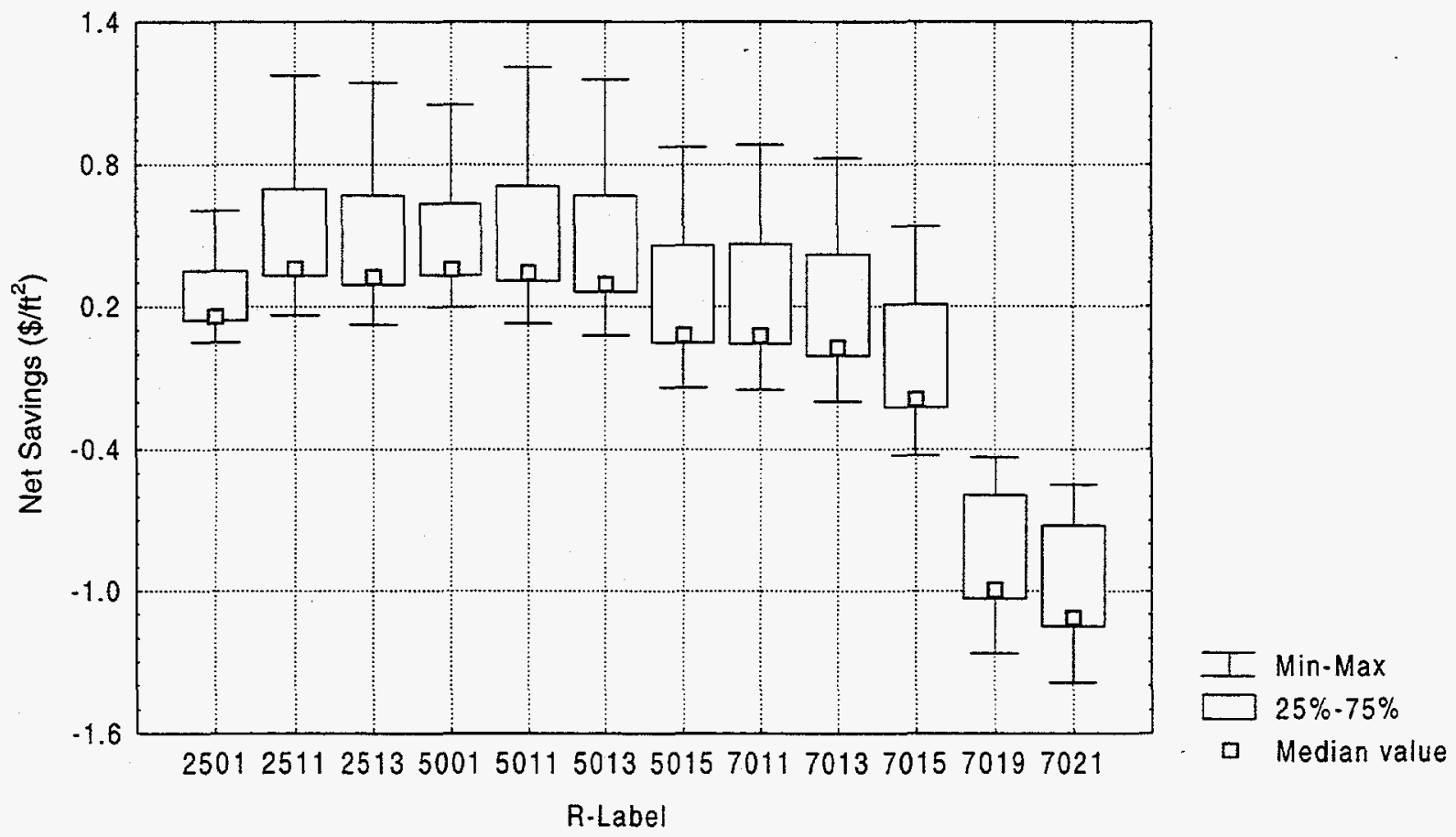

G-5 


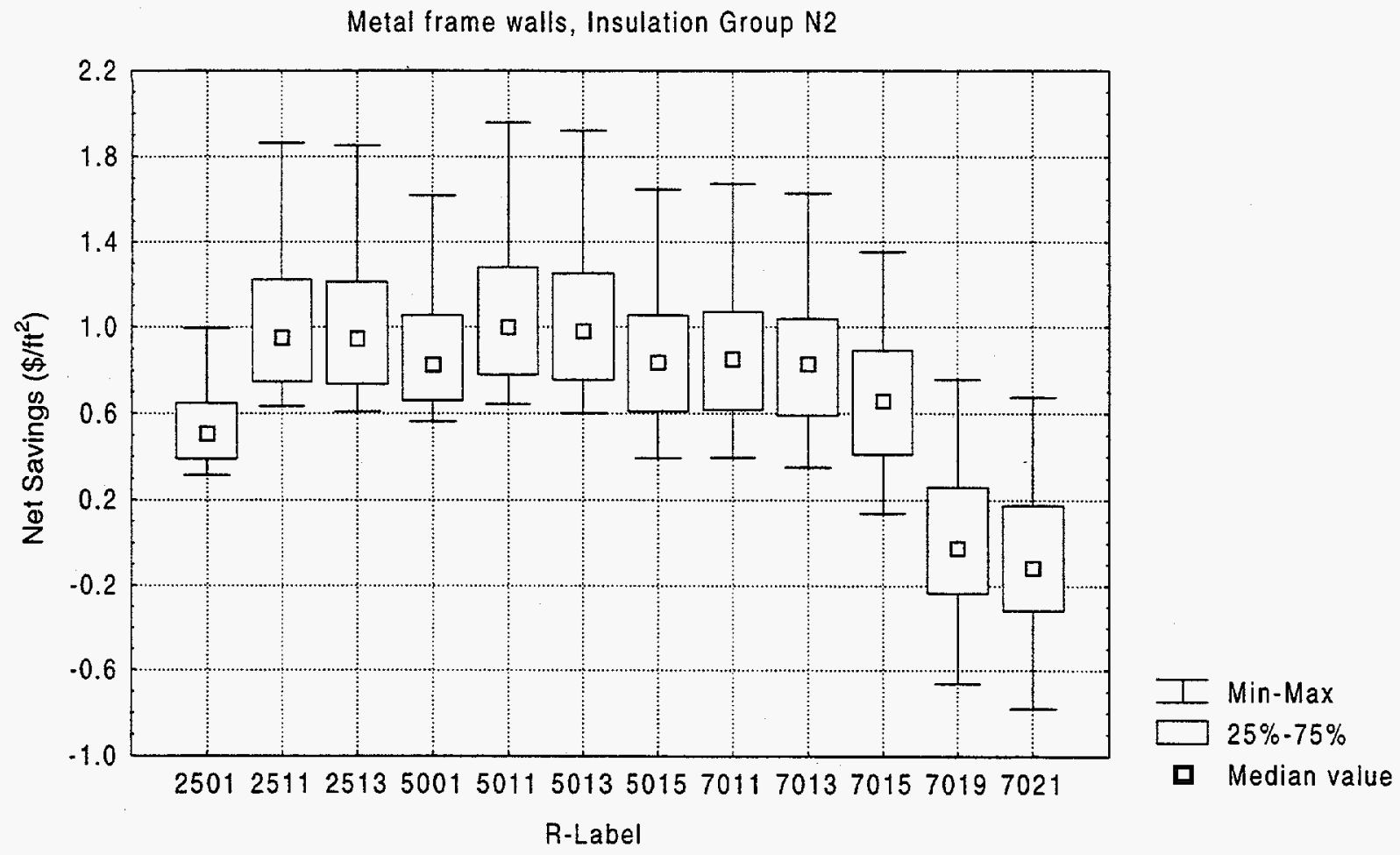

Metal frame walls, Insulation Group N3

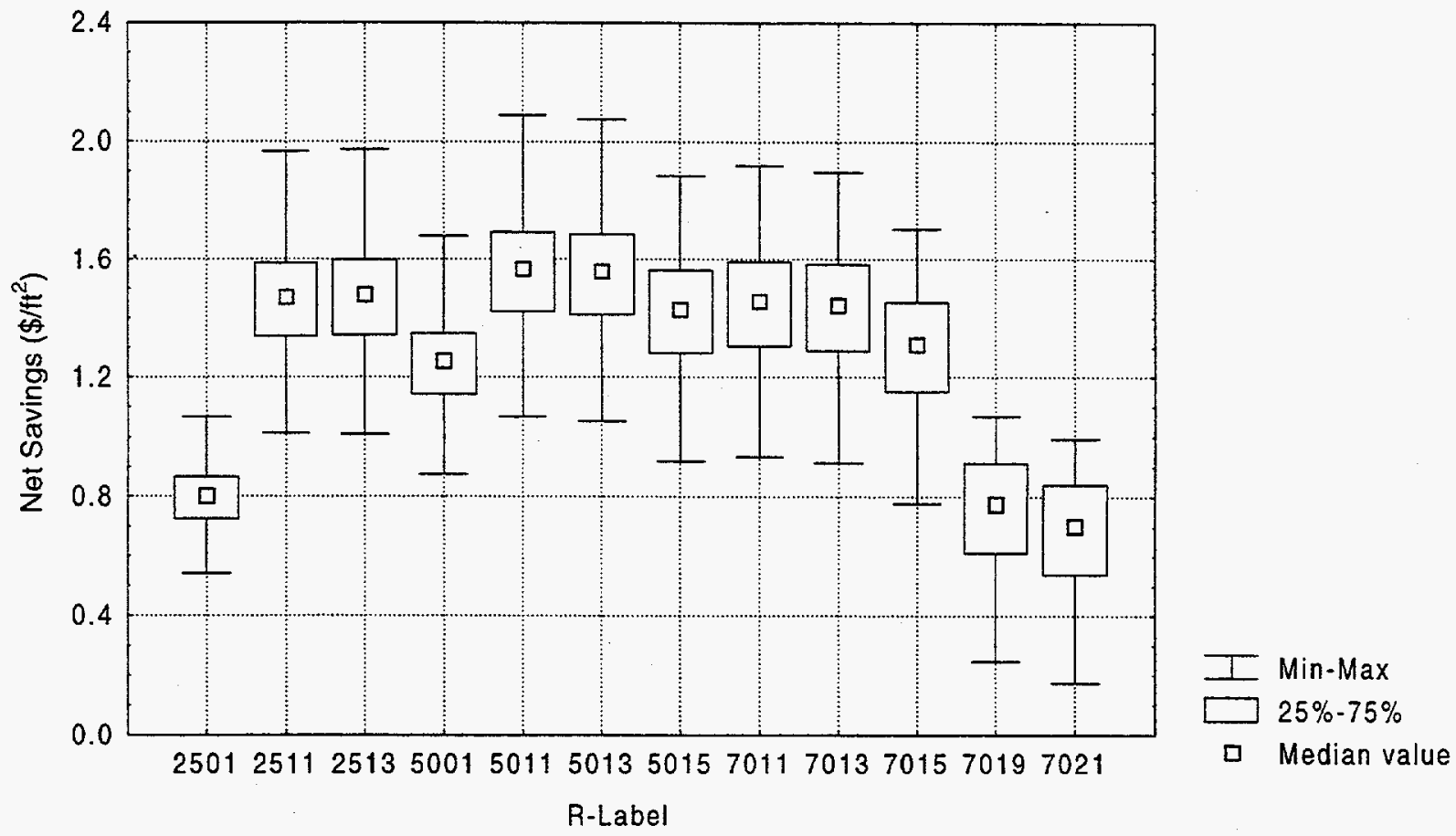




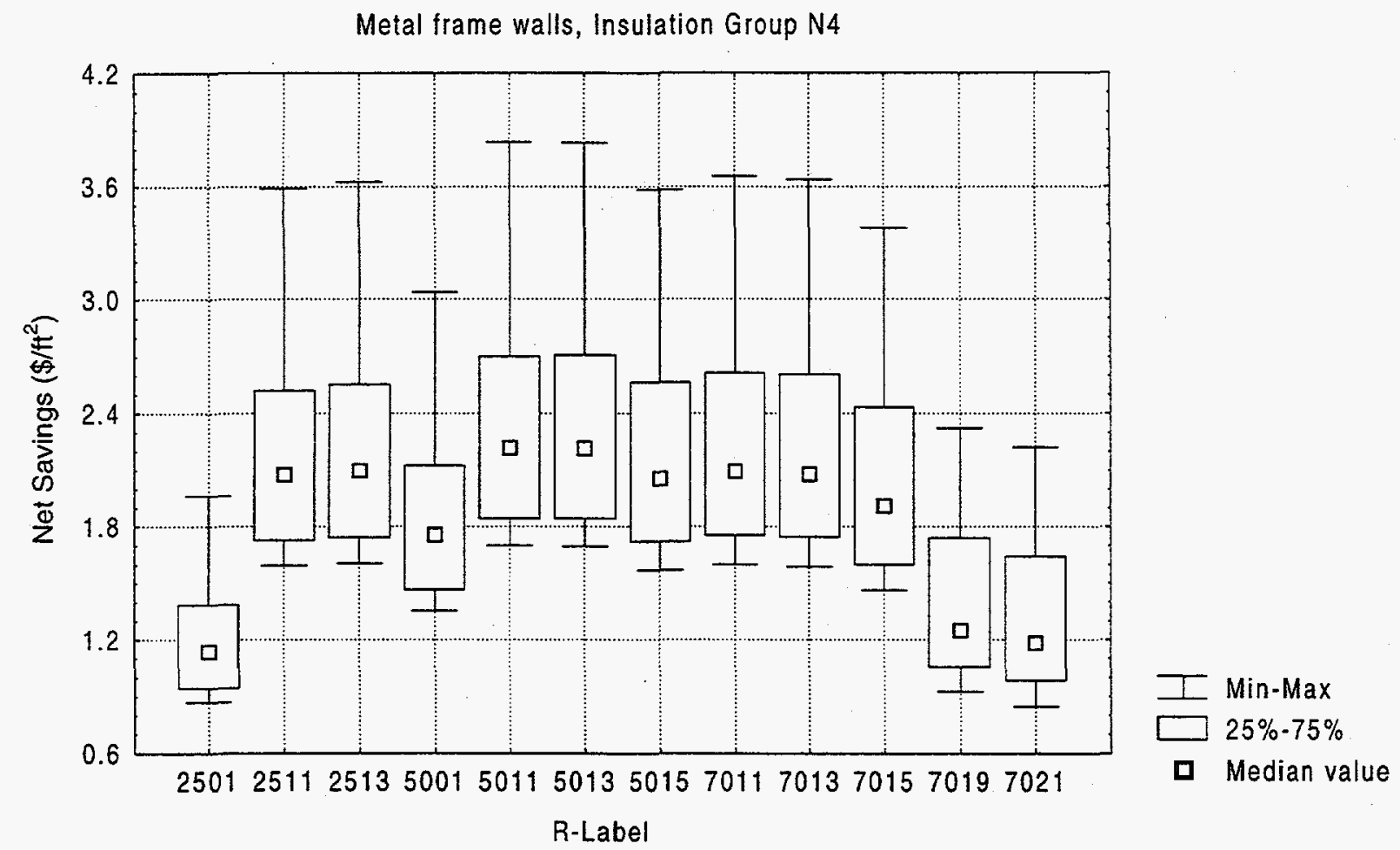

Metal frame walls, Insulation Group N5

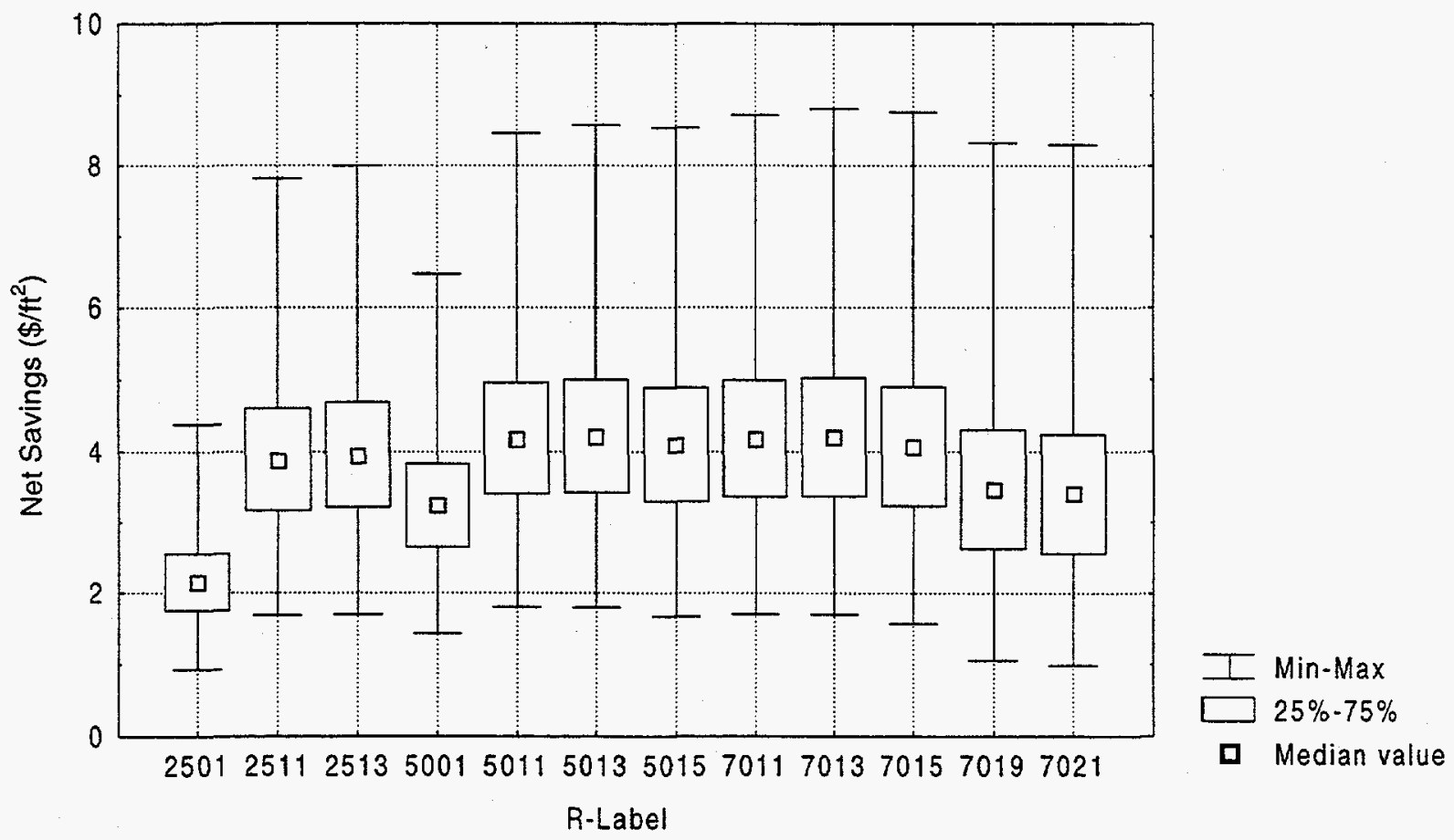




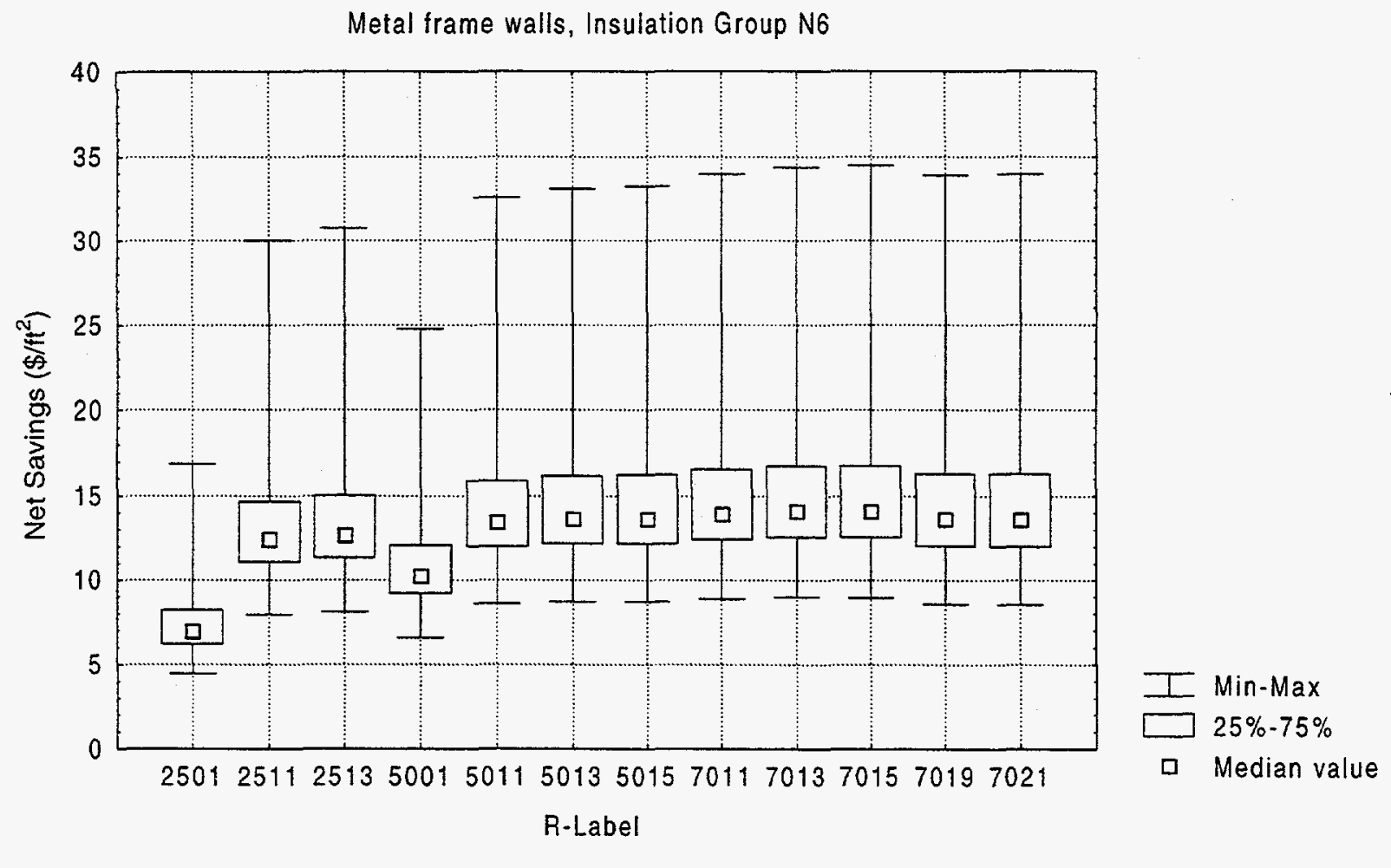

Metal frame walls, Insulation Group N7

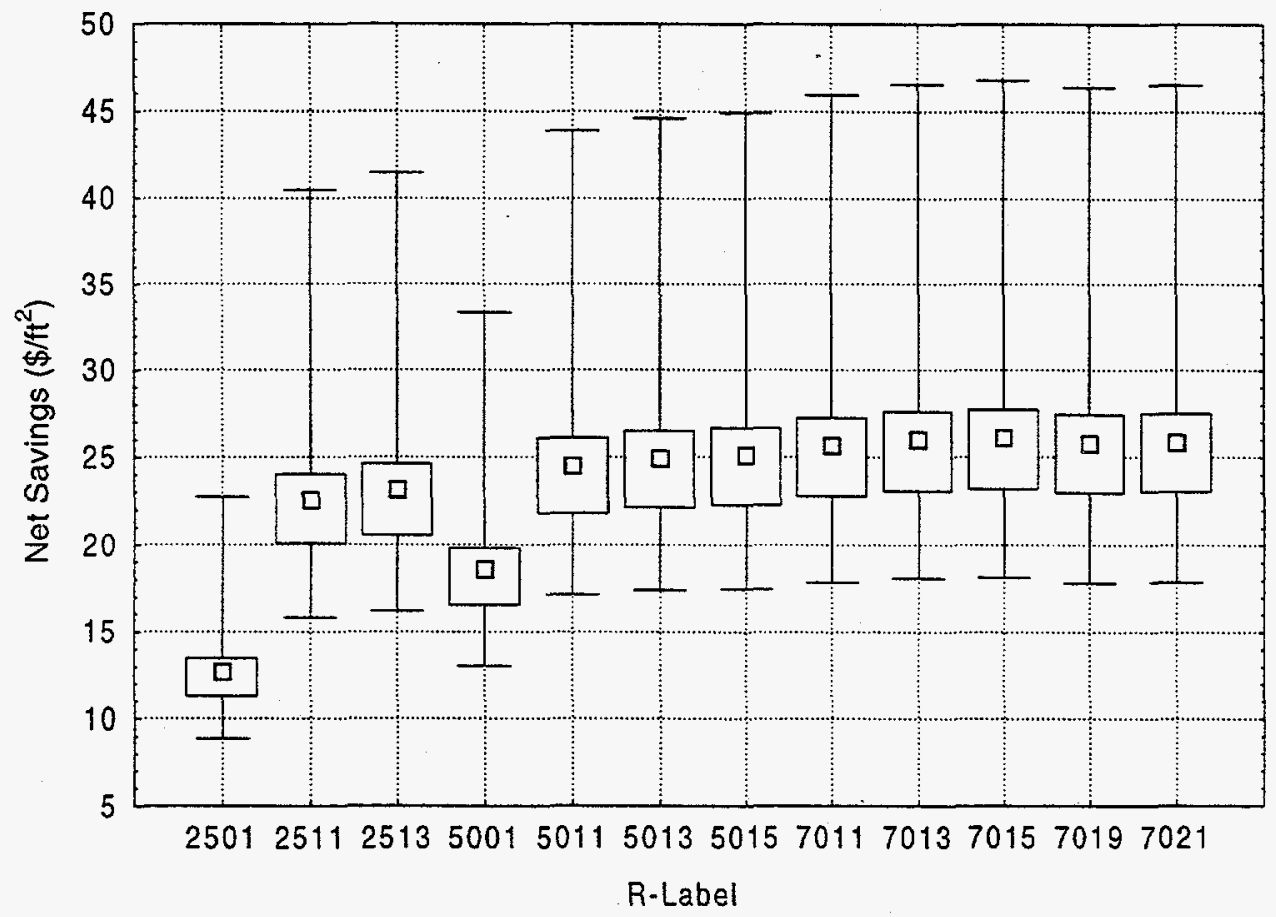

I $\operatorname{Min}-\operatorname{Max}$ $25 \% \cdot 75 \%$

口 Median value 


\section{Appendix H: Summary of Comments Received During the Review Period for the Draft Version of the Doe Insulation Fact Sheet}

The DOE Insulation Fact Sheet was sent in draft form to 41 persons or institutions for review and many helpful comments were received. The most substantive comments are summarized here.

\section{Comments received during the first external review of the DOE Insulation Fact Sheet:}

Energy Efficiency and Renewable Energy Clearinghouse (EREC): reviewed by Paul Hesse (Senior Technical Specialist), Michael Lamb (Technical Specialist - Residential Energy Efficiency), and Cameron Duncan (Technical Specialist - Residential and Commercial Building Design).

"Overall the text of the Fact Sheet (FS) is well written and informative, and seems to be directed to the "average" homeowner (which is a primary customer of our service)." However, the recommendations are viewed by EREC as too complex - they suggest separate inserts for new construction and existing construction as a simplification. EREC prefers the old list of zip codes and fewer categories of fuel and building types to the new maps and tables. It would be helpful to include an additional table that presents information on nominal R-values per inch for different insulations. "Is, can, or will the ZipCode program be made available on the Web? Does it cost anything to get it from ORNL?"

Recommended R-values appear too low and don't appear to be consistent with ORNL's "Building Foundation Design Handbook" values that were based on 1987 costs.

The recommended R-values for metal framed, exterior walls are too low. "Maybe even a separate section on steel-wall framing insulation is necessary to address or clarify these issues." "I keep seeing the steel-framing industry making a marketing hayday out of the fact (sheet) that 'the US DOE says steel structures do not need as much thermal insulation as do other framing systems!' (...insinuating they are MORE thermally efficient than other framing- or building systems.) I think we want to expose the conductivity problems, not reward the system for the frightful inefficiency of current system assemblies. We definitely don't want people to think 'steel-framed assemblies are so efficient they require LESS (life-cycle or otherwise) insulation than other building systems."

If the fact sheet is photocopied, some of the printing will be too small to see and the figures will not be legible.

Energy Star Program: reviewed by Sarah Bretz, Principal Research Associate, Energy Analysis Program, Lawrence Berkeley National Laboratory,

Was 'optimal value engineering', which reduces the amount of framing and thereby increases the R-value of the envelope, considered?

Make the fact sheet less technical, easier for a consumer to understand.

Remove bias toward batt products where possible. 
North American Insulation Manufacturers Association (NAIMA): reviewed by many members, comments presented by Stephen G. Braun, Director, Technical Services

"The R-value recommendations for new construction are not in concert with the code change proposals that DOE has made in the past to the Model Energy Code process. NAIMA has concerns about the potential for conflicting positions from DOE. More recently, DOE has partnered with EPA in sponsoring the Energy Star Programs. In particular, the Energy Star Homes Program sets energy efficiency levels at 30 percent greater than the 1992 CABO Model Energy Code. Maybe DOE should direct home buyers to the EPADOE Energy Star Program or local utility energy efficiency programs rather than attempt specific R-values."

Materials issues: NAIMA objects to every mention of insulation being used to reduce air flows. NAIMA objects to the discussion of insulation compression. NAIMA objects to the discussion of convection within loose-fill insulation.

Fact Sheet scope: Ventilation and moisture control sections questioned. Add recommendations for insulating ducts in attic and crawl spaces.

Framing issues: Consider optimum value engineer framing strategies for wood frame wall assemblies. Add metal framed roof/ceilings and metal framed floors as there is an increasing trend to use metal in residential construction.

Insulation Contractors Association of America: reviewed by Michael Kwart, Executive Director

Suggested additional consumer protection text regarding unscrupulous installation practices.

National Association of Home Builders Research Center (NAHB): reviewed by David Dacquisto, Vice President of Technology, Tom Kenney, and Dan Cautley

Economic analysis issues: NAHB questions the use of a 7\% discount rate. They suggest that a higher rate would more appropriately reflect consumers' debt at much higher interest rates. NAHB also believes that the fact sheet should caution people that they won't get their money's worth on insulation unless they live in the house a long time.

Recommended insulation levels: R-11 is too high for basements in mild climates. Scope: Delete all references to insulation compression as too confusing for consumers. Infiltration discussions questioned.

Consumer protection: Refer readers to NAHB product and installer certification programs.

National Institute of Standards and Technology: reviewed by Douglas M. Burch, NIST Building and Fire Research Laboratory

Would like to see the guidelines and practices for controlling moisture in hot and humid climates be considerable strengthened. Recommends telling consumers in such climates that the combined permeance of the interior construction layers be greater than $2.9 \mathrm{E}-10 \mathrm{~kg} / \mathrm{s}-\mathrm{m}^{2}-\mathrm{Pa}$.

U. S. Department of Housing and Urban Development: reviewed by William Freeborne, Office of the Assistant Secretary for Policy Development and Research

"From my perspective you have included and covered everything I would have 
suggested in the Fact Sheet, so I have no comments."

University of Ilinois at Urbana-Champaign: reviewed by William Rose, School of ArchitectureBuilding Research Council

Crawl space issues handled well. Consider discussing design option of building unventilated attics in warm, humid climates. Limit discussion of moisture control to wintertime because of uncertainties associated with ventilation and air conditioning.

Management Resource Associates: reviewed by George Sievert, Spray Polyurethane Foam Industry Facilitator

Add discussion of spray polyurethane's ability to control air and moisture infiltration.

Seattle Department of Construction and Land Use: reviewed by John Hogan, Senior Energy Analyst

Recommended insulation levels are too low. They are lower than the Model Energy Code and should be revised upward. Emphasize necessity of meeting local building codes.

Discuss thermal short circuits, especially in metal-framed buildings.

Doesn't believe reflective insulation should be called insulation.

Home Energy Magazine: reviewed by Jeanne Byrne, Managing Editor

Improve description of batt installation procedures.

Oak Ridge National Laboratory: reviewed by Ken Wilkes, Dave Yarbrough, David McElroy

\section{Based on the comments received during the first external review, the fact sheet was revised and recirculated for further comments. Shown here is a summary of all comments received on that March 1997 revision to the DOE Insulation Fact Sheet:}

North American Insulation Manufacturers Association: reviewed by members, comments collected by Steve Braun

Editorial changes suggested. Substantive - questions discussion of insulation compression, questions description of structural insulated panel systems, corrects $R /$ in. values for fiberglass products, questions framing cost add-ons for cathedral ceiling calculations, requests that cavity insulation be reconsidered for metal walls in mild climates.

Response: Agreed with many of their comments. However, experimental data support compression discussion. Conflicting experimental data available for structural insulated panel systems, so that statement was retained but made less strong. A small survey of builders supported their cathedral ceiling observation, so those recommendations were recalculated with no additional framing costs for insulation levels up to $R-38$. The wall insulation issue was revisited upon request from several reviewers and the new values 
now show ranges of acceptable insulation levels.

Polyisocyanurate Insulation Manufacturers Association: reviewed by Lorraine Aulisio

Request recognition of $\mathrm{R} 7 / \mathrm{in}$. foil-faced product. Also thinks that insulative sheathing should be more widely recommended.

Response: Foil-faced product added to table, new wall calculations completed, still show sheathing not necessary for mild climates with wood-wall construction.

Reflective Insulation Manufacturer's Association: reviewed by Bill Lippy and David Yarbrough, ORNL

The description of their product should not be longer than others, thinks that it leads people to see it as something that requires more warnings.

Response: Agreed

National Association of Home Builders : reviewed by David Dacquisto, Vice President of Technology, NAHB Research Center

"... am writing to express displeasure, for the record, regarding the 'significant changes' made to the recommended insulation levels for new and existing homes. ..., I am concerned that the recommended levels of thermal protection in the latest version are misleading to the point of being a disservice to the public. ..., I can only conclude that ORNL is ignorant of or indifferent to the economic theory that should properly be applied to the subject." He refers to his earlier economic analysis preferences: NAHB suggests that a higher discount rate would more appropriately reflect consumers' debt at much higher credit card interest rates. NAHB also believes that the fact sheet should caution people that they won't get their money's worth on insulation unless they live in the house a long time.

Response: I cannot agree with their proposals. Using an $18 \%$ discount rate would assume that all purchasers are carrying substantial long term credit card debt, and would ignore the societal benefits attributable to energy conservation. I also think that it's inappropriate to consider only the first owner of a home when evaluating the benefits due to insulation. The energy savings provide a benefit to all future homeowners as well and their economic value will be reflected in the resale price of the home.

Department of Energy, Office of Codes and Standards: reviewed by Stephen Turchen

Editorial suggestions and questions about reflective insulation drawing. Response: The drawing is being revised.

Department of Energy: reviewed by Arun Vohra Many editorial suggestions and substantive comments that include: a request that the discount rate be specified and further information about the life cycle cost analysis be placed on the Web or made available from OSTI, a request to consider wall insulation for solid-walled homes, a request to put all the additional reference sources listed at the back of the Fact Sheet on the Web, and suggested additional caveats about fire hazards associated with overheated wires surrounded by insulation, especially for knob and tube wiring.

Response: Agreed with most comments. The detailed economic discussion will be 
included in the Supporting Documentation, and Fact Sheet readers are referred to that resource for more information. The interior insulation recommendations for abovegrade masonry walls is considered sufficient for the fact sheet.

Pacific Northwest Laboratories: reviewed by Jeff Johnson and Dave Conover Expressed concerns about DOE publishing differing values from their proposed numbers and the current MEC. Questions about preempting Office of Codes and Standards positions, consistency with Federal Trade Commission labeling issues, and recognition of Housing and Urban Development Department financing requirements.

Response: Some verbiage changed to recognize codes and HUD requirements. A more detailed examination of the MEC/Fact Sheet comparison was completed and submitted for DOE review.

Energy Efficiency and Renewable Energy Clearinghouse (EREC): reviewed by Michael Lamb (Technical Specialist - Residential Energy Efficiency)

"The text is fairly informative with the latest information on housing energy conservation. However, we still feel that Tables 5 and 6 understate what we have come to know as 'good' insulation practices. ...the new fact sheet should have it's economics projected out in excess of 10 years from now." They recommend that the evaluation be adjusted to account for savings due to down-sized cooling HVAC equipment. He doesn't understand why the wall cavity $\mathrm{R}$-values are lower that those for crawl spaces. He explains that some terms require clarification, for example, not all basement walls are below-grade. He wants to add basement floor insulation as a recommended measure and offers a detailed installation description. He questions whether R-10 sheathing can be added to an existing wall and points out the door stoop must be removed to avoid a thermal short. The sheathing recommendations for insulated walls in regions E-2 to E-4 have to be wrong based on his instincts. "The entire column 'Cathedral Ceiling' should have the same R-values as the column labeled 'Attic'. After all, a ceiling is a ceiling. They all do the same thing so they all should be treated the same way." Similar questions about why OVE wall cavities, band joist, wall cavities, and crawlspace wall columns don't all have the same R-values. "...concern is with the section 'Basement and Foundations' columns labeled 'crawlspace walls' and 'slab edge' insulation. I know from experience that slab insulation is of great value in my region (VA) yet there is no recommendation for it in this table. This makes me think that this omission is probably carried over into other regions as well."

Response: We have paid a great deal of attention to EREC comments, because their staff deals directly with the Fact Sheet's users. For example, the zip code table (to supplement the simplified zone map) and the $R$-value per inch table were added at their request.

However, many of these requests cannot be supported by the economic analysis (which uses an insulation life of 30 years for new homes, not 10). There are costs associated with wall and ceiling framing, unrecognized by the EREC reviewer, that introduce differences into the table of recommendations from one application to the next. Basement floor insulation could be added at a future date, after appropriate savings estimates are prepared and verified for this measure. Estimating the savings due to downsizing the HVAC equipment is complex, because equipment sizing is based on maximum loads and because much of the equipment is already oversized. I don't feel we 
have an adequate basis to include these savings at this time. We agree that it would be difficult to add two inches of insulative sheathing and have redone all the wall calculations to limit the sheathing thickness to one inch.

Cellulose Insulation Manufacturers Association (CIMA): reviewed by Daniel Lea, Executive Director

Suggested that we expand the fire protection warning for hot flue pipes to include faced batts and plastic foams.

Response: Agreed

Department of Housing and Urban Development: reviewed by William Freebourne of the Office of Policy Development and research

Provides several formatting suggestions.

Seattle Department of construction and Land Use: reviewed by John Hogan

Expressed concern about numbers that are not in agreement with the MEC, "...the basic flaw of the low insulation levels and undermining local code enforcement is unremedied. ...these draft recommendations work against jurisdictions trying to enforce the MEC in accordance with the EPA Act." His numerical comparisons between the draft values and the Washington State Energy Code for new construction show agreement for attic insulation levels. However, he requests that all floor and wall levels (except for metal walls) be increased significantly. Response: We have prepared a detailed comparison of MEC/Fact Sheet recommendations for DOE's consideration. We recognize that new home construction must still meet local building codes and have underlined that statement in the fact sheet to meet his request for a stronger focus on this issue. However, we cannot accomodate his request to change the fact sheet's recommendations to match every local code, especially without a sound economic basis.

Energy Star Program. LBL: reviewed by Sarah Bretz editorial suggestions

Environmental Building News: reviewed by Alex Wilson Offers several editorial corrections and points out errors in the R-value per inch table. Expresses regret that the map was replaced by a Zip-code table and that the insulation thickness table has been replaced. Believed that there were errors in the zip code table because of the low levels recommended for Alaska and because of the differences between geographical neighbors such as Washington D.C and Montgomery County, MD. "Overall, I am very excited about this new insulation fact sheet, particularly the high insulation levels recommended and the fact that rigid foam is always recommended, even in warmer climates."

Response: I discussed the perceived errors with him, they were all due to local low fuel costs.

Oak Ridge National Laboratory (ORNL): reviewed by Kenneth Wilkes and David Yarbrough K.W. suggested adding a criss-cross batt installation recommendation, corrected error in 
Table 2 values for fiberglass, and questioned whether separate advice needs to be given for homes with ducts located with conditioned space. DY suggests that we use the exact wording as the FTC 'Rule', delete reference to cotton, not make recommendations for vapor retarder placement, delete references to pouring loose-fill insulation, and delete the discussion of price variations among contractors. DY questions whether we should discuss metal-framed buildings or recommend different insulation for them than for wood-framed walls. DY questions whether R-10 sheathing could be added to the exterior of an existing wall.

Response: Agree with most comments. However, discussion of duct losses will be reserved for the supporting documentation, because this issue cannot be reduced to any simple rule of thumb for fact sheet readers. Vapor retarder placement and metal wall discussions were retained, many other reviewers had requested this information in earlier reviews. Agreed that two inches of insulative sheathing would be difficult to install, all wall calculations were redone with a maximum thickness of one inch. 